MIPLC Studies

Niteleka Jacob Nichaenzi Jaconiah

\title{
The Effects of Trademark Rights on the East African Common Market
}

Concocting an Appropriate East African Community Trade Mark Model based on the European Trade Mark System 


Universität
Ungsurg


Niteleka Jacob Nichaenzi Jaconiah

The Effects of Trademark Rights on the East African Common Market

Concocting an Appropriate East African Community Trade Mark Model based on the European Trade Mark System 
Printed with financial support of the German Academic Exchange Service (DAAD). Gedruckt mit Unterstützung des Deutschen Akademischen Austauschdienstes (DAAD).

Die Deutsche Nationalbibliothek verzeichnet diese Publikation in der Deutschen Nationalbibliografie; detaillierte bibliografische Daten sind im Internet über http://dnb.d-nb.de abrufbar.

The Deutsche Nationalbibliothek lists this publication in the Deutsche Nationalbibliografie; detailed bibliographic data is available in the Internet at http://dnb.d-nb.de .

a.t.: Munich, Univ., Diss., 2012

ISBN 978-3-8329-7700-9

\section{Auflage 2012}

(c) Nomos Verlagsgesellschaft, Baden-Baden 2012. Printed in Germany. Alle Rechte, auch die des Nachdrucks von Auszügen, der fotomechanischen Wiedergabe und der Übersetzung, vorbehalten. Gedruckt auf alterungsbeständigem Papier.

This work is subject to copyright. All rights are reserved, whether the whole or part of the material is concerned, specifically those of translation, reprinting, re-use of illustrations, broadcasting, reproduction by photocopying machine or similar means, and storage in data banks. Under $\S 54$ of the German Copyright Law where copies are made for other than private use a fee is payable to "Verwertungsgesellschaft Wort", Munich. 


\section{Preface}

This book is a doctoral dissertation undertaken primarily to establish the need for a regional trade mark regime in the East African Community and fathom the extent to which trade mark systems operational in the European Union may serve as a model for such a regime. This demanding task would not have been accomplished but for the support extended to the author by various natural and legal persons.

The author is therefore grateful to Professor Dr. Thomas M.J. Möllers of the University of Augsburg for directing the author's dissertation and to Professor Dr. Annette Kur of the Max-Planck Institute for Intellectual Property and Competition Law (MPI) for serving as the author's internal academic advisor at the MPI where the research on the contents of this book was mostly carried out. The author would also like to thank Dr. Henning Grosse Ruse-Kahn of the MPI for precious comments on earlier versions of excerpts of chapter three of this book.

The German Academic Exchange Services (DAAD) and the MPI deserve special mention for financial grants that enabled the author to carry out his research. The University of Augsburg and the MPI must also be acknowldged for putting their research facilities at the author's disposal. Members of administrative and academic staff of the Munich Intellectual Property Law Center (MIPLC) deserve special thanks: they in their respective capacities contributed to the enrichment of the author's knowledge on the subject of this book during the time when the author was an LL.M. student and later an academic tutor at the MIPLC.

Grateful thanks are also due to Mr and Mrs Heinz Schirdewahn, residents of Munich, Germany; they have been the author's confidants and subsidized the publishing costs of this book.

Finally, the author is deeply indebted to his wife JOYCE for taking over most of household duties thus allowing the author ample time to indulge his desire for completing this book. 


\section{Table of contents}

Preface 5

$\begin{array}{ll}\text { Table of contents } & 7\end{array}$

$\begin{array}{ll}\text { List of abbreviations } & 15\end{array}$

$\begin{array}{ll}\text { Chapter1: General introduction } & 19\end{array}$

Chapter 2: The absence of common trade mark regime in the East African Community 23

A. Introduction 23

B. Institutions responsible for trade mark registration 23

C. Substantive Provisions 24

I. Subject matter of trade-mark protection 24

1. Tanzanian law 25

2. Kenyan and Ugandan laws 25

II. Grounds for trade mark refusal 27

1. Absolute Grounds 27

a) Distinctiveness 27

aa) Under the Tanzania Trade Mark Law 27

bb) Under the Kenyan and Ugandan Trade Mark Laws 28

b) Descriptive and generic marks 29

c) Trade Marks based on a shape of the goods 31

aa) The Tanzanian Law 31

bb) The Kenyan and Ugandan laws 31

d) Other absolute grounds 32

aa) Under the Tanzanian Law 32

bb) Under the Kenyan and Ugandan laws 33

2. Relative grounds 33

a) Prior registered trade mark 33

b) Prior unregistered trade mark 34

c) Business or company name $\quad 35$

d) Trade mark application filed in the name of agent 35

D. Trade mark opposition and cancellation procedure 35

E. Infringement of a registered trade mark 36 
I. Scope of protection 36

1. Use of a mark as a trade mark 37

2. The use of business or company names 38

3. Trade mark with reputation 38

II. Limitation to the exclusive rights 39

1. Use of one's own name 39

2. Descriptive use of a trade mark 39

3. Honest concurrent use of trade marks 40

4. Exhaustion of trade mark rights 40

III. Duties in relation to a registered trade mark 41

1. Renewal of registration 41

2. Obligation to use a registered trade mark 41

F. International trade mark registration $\quad 42$

G. Concluding remarks 43

Chapter 3: The free movement of trade-marked goods in the East African Community 45

A. Introduction 45

B. The Principle of free movement of goods 45

I. Legal basis 45

1. The EAC Treaty (EACT) 45

2. The EAC Common Market Protocol (CMP) 46

3. The EAC Customs Union Protocol (CUP) 46

II. Trade mark rights in the Common Market 47

1. The Common Market Protocol 48

2. The Customs Union Protocol 50

C. Possible solution to the mischief 51

I. Principles of trade mark law 51

1. Trade mark functions 52

a) Trade mark as a badge of origin $\quad 52$

b) Trade mark as a guarantee of quality 53

c) Trade mark functions and markets compartmentalization $\quad 54$ aa) Guarantee of origin $\quad 55$

bb) Guarantee of quality 56

2. The Principle of trade mark exhaustion 57

a) Forms of trade mark exhaustion $\quad 57$

b) National exhaustion $\quad 58$

c) International exhaustion $\quad 59$

d) Regional Exhaustion 61

3. Trade Mark Exhaustion in the EAC 62

a) The general rule 62 
aa) The Tanzanian law 62

bb) The Kenyan and Ugandan laws 63

b) Exception to the general rule 64

a) The Tanzanian law 64

bb) The Kenyan and Ugandan laws $\quad 64$

c) Conclusion thereof $\quad 65$

4. Place of sale for the purpose of exhaustion 65

a) The Tanzanian law $\quad 65$

b) The Kenyan and Ugandan laws 65

II. Relevant principles of international law 67

1. TRIPs Agreement 67

a) Legislative freedom under Article 8 TRIPS 67

b) The chapeau 67

c) The national trade mark exhaustion meets TRIPS'
minimum standards

d) The debate on Article 6 TRIPS 69

2. The GATT $1994 \quad 70$

a) The national treatment $\quad 71$

b) The most favoured nation principle 71

c) Prohibition of quantitative restrictions under Article

d) The general exception clause under Article XX GATT $\quad 74$

aa) Provisos under Paragraph (d) of Article XX GATT 75

bb) Provisos under the chapeau 77

D. Concluding remarks $\quad 77$

Chapter 4: Overview of the European Community trade mark system 79

$\begin{array}{ll}\text { A. Introductory remarks } & 79\end{array}$

B. Office responsible for CTM system 80

C. Subject matter of CTM protection $\quad 81$

I. Substantive requirement - the capability to distinguish 82

II. Formal requirement - the graphical representation 83

III. Essence of the formal requirement 83

IV. Formal and substantive requirements vis-à-vis non-traditional marks 84

$\begin{array}{ll}\text { 1. Smells } & 85\end{array}$

2. Sounds $\quad 87$

3. Colours 88

D. Grounds for Trade Mark Refusal $\quad 90$

I. Absolute Grounds 90

1. Requirements of Article 4 of the CTMR 90

2. Distinctiveness 91 
3. Descriptiveness 95

4. Generic Signs 100

5. Shape Marks 102

6. Further absolute grounds - Article 7(1) (f) - (k) 105

7. Acquired distinctiveness and public policy 108

II. Relative grounds for refusal 111

E. CTM infringement 112

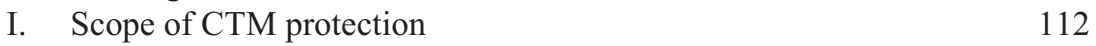

1. Article 9 of the CTMR 112

2. Article 8 of the CTMR 114

$\begin{array}{ll}\text { II. Likelihood of confusion } & 118\end{array}$

1. CTM function and likelihood of confusion 118

2. In whose view is the likelihood of confusion determined? 120

3. Thresholds of likelihood of confusion 122

a) Similarity of trademarks $\quad 122$

aa) Visual similarity 122

bb) Aural or phonetic similarity 124

cc) Conceptual similarity 126

b) Similarity of goods and/or services 128

4. Likelihood of association 131

III. Trademark use as a condition for infringement 131

IV. Protection of a CTM with reputation 133

1. Reputation - what is it? 133

2. Infringing use in relation to a CTM with reputation 135

a) Unfair advantage $\quad 135$

b) Detriment 136

c) Without due cause 137

$\begin{array}{ll}\text { V. Limitations to CTM rights } & 137\end{array}$

1. Honest use of a CTM 137

a) Use of one's own name and address 138

b) Descriptive use of a CTM 139

c) Use of a CTM to indicate intended purpose 139

d) Proviso to Article $12 \quad 141$

2. Exhaustion of CTM rights 141

VI. Duties in relation to CTM 142

1. Renewal of CTM registration 142

2. Obligation to use a CTM 142

VII. Key principles relating to precedence of CTM rights 145

1. Priority Right 145

2. Seniority right 146

F. CTM Application and Opposition proceedings 146

$\begin{array}{ll}\text { I. CTM application } & 147\end{array}$ 
1. Procedure and contents 148

2. Search procedure 149

II. Opposition against CTM registration 152

1. Objection procedure 153

2. Grounds for opposition 154

3. Entitlement to file a notice of opposition 155

4. Opposition proceedings 156

5. Strategies and defences 157

G. Cancellation of CTM rights 160

I. Revocation 160

1. Non-use 160

2. Improper use of a CTM 161

II. Invalidity 162

1. Absolute grounds for invalidity 163

2. Relative grounds for invalidity 166

III. Effects of CTM revocation and invalidity 166

H. International Registration Procedure under the CTMR 167

I. EC as a designated territory 168

II. CTM registration or application as a basis for international
registration

Chapter 5: Interplay between Community trade mark and trademark systems of EU member states 173

A. Introduction 173

B. Essential aspects of Community trade mark system 174

I. Co-existence of trade marks 174

II. Seniority 176

1. Requirements for seniority 177

a) Status of the earlier national trademark 177

b) Triple identity rule 177

aa) Identity of the marks 178

bb) Same owner 178

cc) Identical goods and/or services 178

2. Examination of seniority claim 179

3. Merits and demerits of seniority right 180

a) Merits 180

b) Demerits 181

III. Trade mark conversion 182

1. Grounds for conversion 182

a) Withdrawal of a Community trade mark application $\quad 182$

b) Cessation of effects of Community trade mark 183 
c) Refusal of registration

d) Successful cancellation proceedings 184

2. Grounds for excluding conversion 184

a) Non-use of a Community trade mark 184

b) Grounds for refusal available in one Member State $\quad 184$

C. Enlargement of the European Union and Community trade marks 185

I. Automatic extension of Community trade marks 185

1. Absolute grounds for trademark refusal 185

2. Opposition against registration of Community trade marks 186

3. Cancellation of Community trade marks 186

II. Preservation of earlier rights under national law 187

D. Enforcement of Community trade mark rights 187

I. Application of Brussels Regulation 188

II. Community trade mark courts 189

1. Jurisdiction over infringement and invalidity proceedings 190

a) Infringement actions 191

b) Validity of a Community trade mark 192

2. International jurisdiction 192

a) Connection of parties and courts 193

b) Factors contained in the Brussels Regulation 194

c) Place where harmful act takes place 195

3. Delimitation of jurisdiction 195

4. Related, simultaneous and successive actions 196

a) Similar Community trade mark claims 196

b) Related Community trade mark and national trade mark claims

5) Jurisdiction to award temporary reliefs 199

III. Applicable law 200

1. Rome II Regulation 200

2. Community Trade Mark Regulation 201

a) General applicable law 201

b) The law applicable to sanctions 202

c) Efficacy of lex loci delicti rule 203

IV. Recognition and enforcement of Judgments 204

E. Concluding remarks 206

Chapter 6: Free movement of branded goods in the European Union 207

A. Introduction 207

B. Legal basis for free movement of branded goods 208

I. The Treaty on the Functioning of the European Union 208

II. Principles developed by the ECJ 209 
1. Existence and exercise of intellectual property 209

a) Grundig 211

b) Parke 212

c) Sirena 213

d) Deutsche Grammophon 214

2. Specific subject-matter of intellectual property 215

3. Essential function of a trade mark 216

C. Exhaustion of trade mark rights 217

I. Delineation and forms of trade mark exhaustion 217

II. Rationale of Community trade mark exhaustion 218

III. Conditions for Community trade mark exhaustion 220

1. Putting goods on the market 221

2. Consent 223

a) Consent is given for specific goods 223

b) Express and implied consent 224

c) Contractual restrictions do not vitiate consent 225

3. Burden of proof in relation to exhaustion 226

IV. Factors vitiating exhaustion 227

1. Repackaging and re-affixing of a trade mark 229

a) Artificial partitioning of the common market 230

b) Condition of goods 231

c) Notice of repackaging 231

d) Identity of a person who repackaged the goods 232

e) Reputation of a trade mark 233

2. Extension of repackaging principles to other case scenarios 234

a) Rebranding 234

b) Removal of a stock code $\quad 234$

c) Reworked products 236

D. Concluding summary 236

Chapter 7: A model trade mark regime for the East African Community 239

A. Introduction 239

B. Key Principles governing Community trade mark system 240

I. The principle of unitary character 240

II. The principle of Coexistence of trade mark rights 241

III. Interaction between trade mark coexistence and unitary
principles

C. Principles that should govern the EAC trade mark system 243

I. Modifications to the principle of unitary character 244

1. Abandonment of the unitary principle 245 
2. Unitary character not to be defined by the entire scale of the regional bloc

3. Justifications for the proposed modifications to the unitary principle

a) Free movement of goods

b) Competition in trade-marked goods

c) Unitary character as a means of expansion of economic activities

II. Modifications to the principle of co-existence 249

1. Abolition of the national trade mark

2. Coexistence as a transition solution

a) Incentives to ensure that the national system fades away 250

b) The Benelux model: Transforming existing national trade marks into EAC trade marks

3. The German trade mark model

D. The Proposal for the EAC trade mark regime

I. Acquisition of trade mark rights and the extent of validity

1. Non-examination system at national offices

2. Examination system at the EAC trade mark office 258

3. Trade mark use requirement and the consequences thereof 259

a) The use requirement 259

b) Consequences of non-compliance with the use requirement

II. Integration of the existing national trade mark rights into the

EAC trade mark regime

$\begin{array}{ll}\text { 1. National trade mark registrations } & 261 \\ \text { 2. Applications for national trade marks } & 261\end{array}$

3. Conciliation board 


\section{List of Abbreviations}

\#

(K)

(T)

AG

ALR

ARIPO

Ariz. J. Int'l \& Comp. L.

BRELA

CAK

Cap

CCK

CCT

Cf.

CFI

CJEU

CMLR

CMP

Co.

CTM

CTMIR

CTMR

CUP

DG

E.I.P.R.

EA

EAC

EACJ

EACT

EC

ECR

ed(s).

ed.

EEA

EFTA

eKLR

ETMR
Number

Kenya

Tanzania

Aktien Gesellschaft

African Law Reports

African Regional Intellectual Property Organization

Arizona Journal of International Comparative Law

Business and Licensing Agency of Tanzania

Court of Appeal of Kenya

Chapter

Commercial Court of Kenya

Commercial Court of Tanzania

Confer

European Court of First Instance

Court of Justice of the European Union

Common Market Law Review

Common Market Protocol

Company

Community trade mark

Community Trade Mark Implementing Regulations

Community Trade Mark Regulation

Customs Union Protocol

Department General

European Intellectual Property Review

East Africa Law Reports

East African Community

East African Court of Justice

East African Community Treaty

European Community

European Court Reports

Editor(s)

Edition

European Economic Area

European Free Trade Area

Electronic Kenya Law Reports

European Trade Mark Reports 
EU

FRG

GATT

GC

GDP

GDR

$\mathrm{GmbH}$

GRUR Int

GRUR

HCK

HCT

$\mathrm{HCU}$

I.P.Q.

IIC

INTA

Intell. Prop. Bull.

Intell. Prop. J.

J. Pat. \& Trademark Off. Soc'y

J.L. \& Econ.

JWT

K.

KIPI

Ltd.

Marq. Intell. Prop. L. Rev.

NERA

No.

OHIM

OJ

OUP

Para(s).

R.E.

R.P.C.

$\mathrm{S}$.

SS.

$\mathrm{T}$.

TD

TFEU

Trademark Rep.
European Union

Federal Republic of Germany

General Agreement on Trade and Tariffs

General Court of the European Union

Gross Domestic Product

Germany Democratic Republic

Gesellschaft mit beschränkter Haftung

Gewerblicher Rechtsschutz und Urheberrecht /

Internationaler Teil

Gewerblicher Rechtsschutz und Urheberrecht

High Court of Kenya

High Court of Tanzania

High Court of Uganda

Intellectual Property Quarterly

International Review of Intellectual Property and

Competition Law

International Trademark Association

Intellectual Property Bulletin

Intellectual Property Journal

Journal of Patent and Trademark Office Society

Journal of Law and Economics

Journal of World Trade

Trade Marks Act of Kenya

Kenya Industrial Property Institute

Limited Liability Company

Marquette Intellectual property Law Review

National Economic Research Associates

Number

European Office for the Harmonization in the Internal

Market (Trade Marks and Designs)

Official Journal

Oxford University Press

Paragraph(s)

Revised Edition

Reports of Patent, Design and Trade Mark Cases

Section

Sections

Trade and Service Marks Act of Tanzania

Community Trade Mark Directive

Treaty on the Functioning of the European Union

Trade Marks Reporter 
TRIPS

U.

UK

USRB

WIPO

WTO
Agreement on Trade Related Aspects of Intellectual Property Rights

Trade Marks Act of Uganda

United Kingdom

Uganda Registration Services Bureau

World Intellectual Property Organization

The World Trade Organization 


\section{Chapter1: General introduction}

Trade mark rights afford a privileged monopoly to the proprietor. As a direct consequence of this monopoly, trade mark owners are able to restrict others from dealing with a trade-marked product and thereby affect the freedom of movement of goods which legal systems of regional blocs such as the European Union (EU) or the East African Community (EAC) guarantee. In most cases, a trade mark proprietor derives the ability to circumvent the free movement principle from the national systems of trade mark protection. By their nature, national trade mark systems are established to serve national markets. This holds true even where the national markets are integrated to form a single market. To play a meaningful role in a single market of a given regional bloc, national trade mark systems of the Member States may necessarily be supplemented with a regional trade mark system. The regional trade mark system would thus integrate the national trade mark systems into the common market by linking trade mark rights with principles governing the common market. In the EU the task of integrating trade mark rights into the common market was accomplished through the Community Trade Mark Regulation (CTMR) ${ }^{1}$ which introduced a regional trade mark regime.

Rules underlying the EU's regional trade mark system may guide authorities in other regional blocs, such as the East African Community (EAC), to regulate their common markets. The East African Community, established in 1999, comprises five Partner States, namely, Burundi, Kenya, Rwanda, Tanzania and Uganda. Apparently, the Community has an operational common market in which several freedoms, including the free movement of goods are guaranteed. ${ }^{2}$ National trade mark systems operational in the Partner States have not yet been integrated into the Community regulatory framework. There is thus a potential danger that national trade mark rights may be invoked to circumvent the principle of free movement of goods underlying the EAC common market.

The principal aim of this dissertation is to investigate the effects of trade mark rights on the EAC common market and to provide a solution thereto. The dissertation identifies and scrutinises various scenarios under which the national

1 i.e. Council Regulation (EC) No 40/94 of 20 December 1993 on the Community trade mark. This Regulation was repealed and replaced by Council Regulation (EC) No 207/2009 of 26 February 2009 on the Community trade mark (codified version). 
trade mark systems of the EAC Partner States are likely to affect the proper functioning of the EAC common market. In this regard, chapter 2 analyses the national trade mark laws of the EAC Partner States and depicts the absence of a uniform trade mark regime in the EAC. Absence of uniformity of trade mark regulation is clear evidence that the national trade mark systems are still independent of each other and hence, the systems provide a platform for trade mark proprietors to impair the proper functioning of the EAC common market. Additionally, the regulation of the principle of free movement of goods governing the EAC common market is closely scrutinised in chapter 3 to find out whether and how the principle, as enshrined in the relevant EAC legal instruments, facilitates the free movement of branded goods. In this respect, the dissertation makes it clear that the general principle of the free movement of goods underlying the EAC common market does not have sufficient legal force to guarantee the free movement of branded goods across the entire EAC area. Thus, chapter 3 attempts to develop an alternative regulation of the free movement of trade-marked goods on the basis of principal functions of trade marks and on the basis of international rules enshrined in the agreement on the Trade-related Aspects of Intellectual Property (TRIPS agreement) and the General Agreement on Tariffs and Trade (GATT). However, in the light of the findings contained in the chapter, a free movement regime regulated on the basis of principles of trade mark law such as where restriction on the movement of trade-marked goods is permitted only if such a restriction is necessary to allow a trade mark to perform its functions, is not a better approach, for it is undertaken on a case-by-case basis and does not curb every scenario in which trade mark rights are disguisedly invoked to hamper free movement of goods. This case-bycase regulation of the free movement of branded goods may be avoided if a Community trade mark system is established to integrate the national trade mark systems of the EAC Partner States into the EAC common market.

A proposal for a Community trade mark regime that could possibly suit the EAC common market is presented in chapter 7. The proposal is, by and large, modelled on the EU trade mark system. To pave a way for this proposal, chapter 4 outlines the EU trade mark system, by setting out substantive and procedural principles governing creation, protection and termination of EU's regional trade mark rights. In the same vein, chapter 5 of the dissertation offers, in a specific context, a discourse on how the interplay between the national trade mark regimes of the EU Member States and the Community trade mark regime is achieved. This is followed by an examination, in chapter 6 , of the free movement regime of branded goods in the EU common market.

Although the EAC has five Partner States, only the laws of three States, namely, Kenya, Tanzania and Uganda are examined in this dissertation. The fact 
that these countries are the EAC founder States and that they share similarity of legal systems inherited from the British colonial master ${ }^{3}$ has motivated the author to delimit the analysis in the dissertation accordingly. However, the findings contained in this thesis are generalised to benefit the EAC as a whole.

3 Cf. Footnote No 98, in: JACONIAH, J., "The Requirement for Registration and Protection of Non-Traditional Marks in the European Union and in Tanzania”, 40(7) IIC 756,773 (2009). 
Chapter 2: The Absence of Common Trade Mark Regime in the East African Community

\section{A. Introduction}

Are the substantive provisions of the national trade mark legislations of the Partner States of the East African Community (EAC) similar? The positive response to this question would negate a central thesis of this chapter. The chapter takes the view that unless the substantive differences inherent in the national trade mark laws of the EAC Partner States are streamlined and harmonised, a common EAC trade mark regime would be impossible. ${ }^{4}$ As a step leading to the foregoing conclusion, the Chapter addresses the subject matter of trade mark registration, and the grounds that the national trade mark offices of the EAC Partner States may invoke to refuse registration of a trade mark. This is followed by an outline of trade mark opposition and cancelation procedure. Issues pertaining to trade mark infringement and the system of international trade mark registration are depicted in the chapter as well. Preliminary considerations are directed to the institutional set up of the national trade mark regimes of the EAC Partner States.

\section{B. Institutions responsible for trade mark registration}

Trade and service marks Act of $1986^{5}$ (henceforth T.) governs trade mark administration in Tanzania. Trade mark rights in Kenya and Uganda are respectively created and protected based on the Trade Marks Act (Chapter 506 of the laws of Kenya) of 1957 (henceforth, K.) as amended and the Trademarks Act $^{6}$ of Uganda of 2010 (henceforth, U.). These legislations establish an office of

4 The substantive differences depicted in this chapter are only exemplary. It is not the aim of the chapter to go into extensive discussion insofar as the differences are concerned, but just to highlight the key differences that are essential for the attainment of a common EAC trade mark regime.

5 Act No. $12 / 86$ of the Laws of Tanzania.

6 Act No 17 of 2010. This Act, which is published in the Uganda Gazette No. 53 Volume CIII dated 3rd September 2010, repeals the Trademarks Act (Chapter 217 of the laws of Uganda) of 1953 (cf. S. 99 of the Act). 
Registrar of Trade (and Service) Marks, who is charged with a duty to exercise the powers conferred on him by a respective legislation. ${ }^{7}$

Section 3, T., establishes the Tanzanian Trade and Service Marks Office. The office forms an integral part of the Business Registration and Licensing Agency (BRELA) established, under the Ministry of Industry and Trade, to provide services in relation to business name registration, trade and service marks registration, patents, company registration, and industrial licensing. ${ }^{8}$ Thus, BRELA is an administrative support framework that facilitates the administration of four registries. ${ }^{9}$ The Kenya industrial property institute (KIPI) is a parastatal organisation established, under the ministry of industrialisation of Kenya, to deal with inter alia trade mark registrations. ${ }^{10}$ The Ugandan Trade Marks Office is under the control of the office of the Registrar General of the Uganda Registration Services Bureau (URSB) ${ }^{11}$ whose mandates are overseen by the Ministry of Justice and Constitutional Affairs. ${ }^{12}$

\section{Substantive Provisions}

\section{Subject matter of trade-mark protection}

Protection of a sign as a trade or service mark under the trade mark legislation of Tanzania, Kenya and Uganda is dependent on the sign concerned being registered. ${ }^{13}$ Under some exceptional circumstances, unregistered trade mark

$7 \quad C f$. SS. 4, 3 and 2 of $\mathrm{T}, \mathrm{K}$ and $\mathrm{U}$ respectively.

8 More information on BRELA is available at $<$ http://www.brela-tz.org > (status: 30 July 2012).

9 These registries are the Registry of Companies (under the Companies Act No. 12 of 2002), business names (under the Business Names Act Cap 213 of the laws of Tanzania), Trade and Service Marks (under the Trade and Service Marks Act No. 12 of 1986) and Patents (under the Patents Act No. 1 of 1987).

10 More information on KIPI is available at $<$ http://www.kipi.go.ke $>$ (status: 30 July 2012).

11 URSB is established by the Uganda Registration Services Bureau Act No. 7/1998 (Cap 210 of the laws of Uganda). According to the long title of the Act, USRB Act establishes an agency for miscellaneous registrations and collection and accounting for revenues under various relevant laws and for the enforcement and administration of those laws and provide for other related matters.

12 See relevant information at $<$ http://www.wipo.int/directory/en/urls.jsp $>$ (status: 30 July 2012).

13 S. 14(1) T., S. 30 T., S. 5, K. \& Sec 34, U. See also M. WEKESA \& B. SIHANYA (eds), "Intellectual Property Rights in Kenya" 230 (Konrad Adenauer Stiftung, Berlin and Nairobi 2009). 
rights may still be enforced. ${ }^{14}$ Registration of a trade mark is prima facie

evidence that the mark has fulfilled all conditions required of a valid mark. ${ }^{15}$ To meet these conditions a sign must be distinctive ${ }^{16}$ and must fall within the definition provided for under the respective trade mark legislation. ${ }^{17}$

\section{Tanzanian law}

The Tanzanian trade mark legislation qualifies a sign eligible for trademark protection in the following words:

trade or service mark means any visible sign used or proposed to be used upon, in connection with or in relation to goods or services for the purpose of distinguishing in the course of trade or business the goods or services of a person from those of another. ${ }^{18}$

To get a complete picture of the signs capable of functioning as trademarks under the Tanzanian law, one has to supplement the above definition with the operational definition of the visibility requirement provided for under the respective law. Section 2, T. stipulates that:

"visible sign" means any sign which is capable of graphic reproduction, including a word, name, brand, devise, heading, label, ticket, signature letter number, relief, stamp, seal, vignette, emblem or any combination thereof. ${ }^{19}$

\section{Kenyan and Ugandan laws}

The term "trade mark" is operationally employed in the Kenyan Act to refer to a mark used or intended to be used ${ }^{20}$ in relation to goods or services to indicate in the course of trade that a connection exists between the goods or services being marketed under the mark and a person who has a right to use the mark. ${ }^{21}$ On its part, the Ugandan Trade Marks Act delineates the term "trademark" to mean "a sign or a mark or combination of signs or marks capable of being represented

14 These circumstances are discussed in section C (II) (2) (b) of this chapter.

15 S. 14(2), T., S. 46, K. \& S. 58, U. See also the ruling of the High Court of Tanzania (Commercial Court Division) in Kibo Match Group Ltd v. Mohamed Enterprises (T) Ltd., Civil Case No. 6 of 1999 (Dar Es Salaam Registry (unreported)), para. 17.

16 S. 16 T., S. 12(2), K. \& S. 11(2), SS. 9 \& 10 U.

17 S. 2, para. 14, T., S. 2(1), para. 26 (a) \& (b), K., \& S. 1(1), para 15, U.

18 S. 2, para. $14, \mathrm{~T}$.

19 S. 2, para. $18, \mathrm{~T}$.

20 A trade mark is presumed to be used in legal context if it is used in a printed form or any other visual representations ( $c f$. S. 2(2)(a), K.).

21 S. 2(1), para. 26 (a) \& (b), K. 
graphically and capable of distinguishing goods or services of one undertaking from those of another undertaking". ${ }^{2}$

As regards signs which a trade mark may consist of, both Kenyan and Ugandan laws do not seem to put a limit to eligible signs, and for that matter they are not at variance with the position under the Tanzanian law. Essentially a "device, brand, heading, label, ticket, name, signature, word, letter, numeral or any combination of them" may constitute a trade mark registrable in Kenya or in Uganda. ${ }^{23}$ The relevant provision of the Kenyan Act adds to the foregoing list "a distinguishing guise and slogan" 24 - the distinguishing guise in relation to goods being defined to mean a shape or a configuration of containers of the goods. ${ }^{25}$ Moreover, the Kenyan Law makes an important specification: where eligible signs are combined, they will still qualify for registration irrespective of whether such combination is rendered in two or three dimension. ${ }^{26}$

The foregoing delineation of the subject matter of trade mark protection under the trade mark laws of Tanzania, Kenya and Uganda complies with the legal standards set out under the Agreement on Trade-Related Aspects of Intellectual property Rights (henceforth, TRIPS) ${ }^{27}$ Article 15(1) TRIPs, which describes protectable subject matter of trade marks, indicates that Contracting Parties are obliged to register as a trade mark "any sign, or any combination of signs, capable of distinguishing the goods or services of one undertaking from those of other undertakings".

22 S. 1(1), para 15, U. By referring to concepts such as "graphical representation" and capability to distinguish, the trade mark definition contained in the Ugandan trade mark law is similar to the one enshrined in the relevant laws governing trade mark matters in the European Union ( $c f$. Chapter 4 supra, which offers an overview of the system of trade mark governance in the EU).

23 S. 2(1), para. 12, K. \& S. 1(1), para 13.

24 S. 2(1), para. $12, \mathrm{~K}$.

25 S. 2(1), para. $7, \mathrm{~K}$.

26 S. 2(1), para. $12, \mathrm{~K}$.

27 Tanzania, Kenya and Uganda are signatories to the Agreement Establishing the World Trade Organization (WTO) adopted at Marrakesh on April 15, 1994 in which the Agreement on TRIPs forms a part ( $c f$. KIEFF, F. S. \& NACK, R., "International, United States and European Intellectual Property: Selected Source Material 2007-2008" 34 (Aspen Publishers, New York 2006). 


\section{Grounds for trade mark refusal}

\section{Absolute Grounds}

A detailed discourse on absolute grounds for trademark refusal is covered in chapter 4 infra, in the context of the EU Community Trade mark law. The aim of these grounds is to exclude from registration various types of marks such as those which are not distinctive, or those which are descriptive of the goods or services. Others are generic signs, and the type of a shape excluded from registration by a stipulation of the law. A brief discussion on these grounds is offered below in the context of Tanzanian, Kenyan and Ugandan trade mark law.

\section{a) Distinctiveness}

aa) Under the Tanzania Trade Mark Law

Section 16 of the Tanzania Trade and Service Marks Act, apart from providing that "[a] trade or service mark shall be registered if it is distinctive" 28 , also expounds the standards a sign has to attain if it is to be regarded as distinctive. Within the ambit of the Section:

[A] trade or service mark is distinctive if it is capable, in relation to goods or services in respect of which it is registered or proposed to be registered, of distinguishing goods or services with which its proprietor is or may be connected in the course of trade or business from the goods or services in the case of which no such connection subsists, either generally or, where the trade or service mark is registered or proposed to be registered subject to limitations, in relation to use within the extent of registration. ${ }^{29}$

The Section further provides that:

In determining whether a trade or service mark is capable of distinguishing for the purpose of subsection (2), regard shall be to the extent to which:- (a) The trade or service mark is inherently capable of distinguishing as aforesaid; and (b) By reason of the use of the trade or service mark or of any other circumstances, the trade or service mark is in fact capable of distinguishing as aforesaid. ${ }^{30}$

Capability to distinguish, within the ambit of the above quoted provisions, is detached from the sign as such for it is viewed in the light of the relation between the sign, its holder and the products or services. Generally, a trade mark is capable of being registered as long as the owner can demonstrate that his trade 
mark (which of course must be a visible sign) ${ }^{31}$, can distinguish or has already distinguished his goods or services from those of others. Thus, section 16 of the Tanzania Trade and Service Marks Act calls for the assessment of a trademark's capability to distinguish to be done in view of the goods and services.

\section{bb) Under the Kenyan and Ugandan Trade Mark Laws}

The Trade Mark Acts of Kenya and Uganda determine distinctiveness based on the register of trade marks. Under these laws, an assessment must be made to find out whether a particular mark qualifies to be registered either in part A or part $\mathrm{B}$ of the register. The logic behind dividing the register into two parts is to isolate the marks in respect of which an irrefutable, legal presumption of distinctiveness must be cast or those in respect of which there is ample evidence to show that they are distinctive from those which have potentials to distinguish goods and services of one undertaking from those of others. ${ }^{32}$ The relevant provisions of the law regard the following categories of marks as registrable in part A of the register:

(a) the name of a company, individual or firm, represented in a special or particular manner; (b) the signature of the applicant for registration or some predecessor in his business; (c) an invented word or invented words; (d) a word or words having no direct reference to the character or quality of the goods, and not being according to its ordinary signification a geographical name or a surname; (e) any other distinctive mark, but a name, a signature or a word or words, other than such as fall within the descriptions in paragraphs (a), (b) and (c), shall not be registrable under this paragraph except upon evidence of its distinctiveness. ${ }^{33}$

In keeping with an operational definition of distinctiveness in relation to a mark registrable in part $\mathrm{A}$ of the register, the marks enumerated above are regarded distinctive if they are "adapted in relation to the goods in respect of which a trade mark is registered or proposed to be registered, to distinguish goods which the proprietor of the trade mark is or may be connected in the course of the trade from goods in the case of which no such connexion subsists...". ${ }^{4}$

A trade mark which qualifies for registration in Part A of the register may as well be registered in Part B. As long as a particular mark possesses some potential to distinguish goods or services, it fulfils the requirements for registra-

31 Visibility of a sign is a mandatory, formal requirement for trademark registration under the Tanzania Trade and Service Marks Act (cf. S. 2, para. 14, T.).

32 Cf. SS. $12 \& 13, \mathrm{~K}$. and SS. $9 \& 10, \mathrm{U}$.

33 S. 12(1), K. \& S. 9(1), U.

34 S. 12(2), K. \& S. 9(2), U. 
tion in part B of the register. ${ }^{35}$ This particular mark must be capable, "in relation to the goods in respect of which a trade mark is registered or proposed to be registered, of distinguishing goods with which the proprietor of the trade mark is or may be connected in the course of the trade from goods in the case of which no such connexion subsists..."

Both laws recognise the legal position that a trade mark may be inherently distinctive or may acquire a secondary meaning in the course of trade and thus becoming distinctive. However, the fact that the pertinent laws divide the trade mark register into two parts connotes that the concept of inherent or acquired distinctiveness is applied differently depending on which part of the register a trade mark concerned is to be registered. This conclusion can be buttressed by the fact that these concepts are only relevant to determine whether a particular mark can serve a trade mark function or not. With this view in mind and insofar as part $\mathrm{A}$ of the register is concerned, all the marks mentioned in paragraphs (a) to (d) of Sections 12(1) and 9(1) of K. and U. respectively, are regarded as being inherently adapted to distinguish, whereas the marks that qualify for registration under paragraphs (e) of the above sections their acquired meaning is decisive to finding out whether they are actually adapted to distinguish.

When it comes to a mark registrable in part B of the register, potentiality to distinguish can be inherent or can be achieved by actually using a mark. ${ }^{37}$

One cannot criticise the distinction made between the proof of distinctiveness for the purpose of part A or part B of the register without questioning the essence of dividing the register in two parts, and whether, in a modern trade mark protection regimes, this division is still needed. ${ }^{38}$ While this question deserves an analysis, it is not the purpose of this chapter to extend a discourse thereto.

\section{b) Descriptive and generic marks}

A trade mark is regarded as descriptive if it is used to describe the characteristics of the goods or services which it markets, rather than performing a distinguishing role. This legal concept is not clearly described under the Tanzanian, Kenyan,

35 S. 13(3), K. \& S. 10(4), U.

36 S. 13(1), K. \& S. 10(2), U.

37 S. 13(2), K. \& S. 10(3), U.

38 For instance, only one trade mark register is maintained under the Tanzanian Trade and Service Marks Act, 1986 (cf. SS. 6(1) and 2, para. 6, T.). Prior to the enactment of the above Tanzanian law, the Trade Marks Ordnance (Cap. 394 of the laws of Tanzania) required the trade mark registrar to divide a trade mark register into two parts. However, the 1986 trade mark law has abolished this division ( $c f$. S. 62, T.). 
and Ugandan laws. As to what may be likened to the principle of descriptiveness, these laws incorporate a provision entitling trade mark proprietors to disclaim certain features of a trade mark which are considered to be nondistinctive or to be common to trade. ${ }^{39}$ A monopoly in these features is not allowed on a simple logic that a non-distinctive feature should be left open for every member of the society to use it. Indeed, a feature considered to be common to a particular trade cannot be monopolised since this would deny a large section of the society an access to an essential instrument without which they cannot be able to engage themselves on a particular trade. ${ }^{40}$

The term "generic mark" is used in the context of trade mark law to refer to a trade mark which was once distinctive but in the course of time has turned out to be used as a name of the very goods it used to distinguish. While the concept "generic mark" is not addressed in the Tanzanian law, the Kenyan and Ugandan Acts contain similar concepts under the heading "words used as name or description of an article or substance". ${ }^{41}$ A trade mark, which after registration turns out to serve as the "name or description of an article or substance or of some activity", cannot automatically be invalidated based on the relevant provisions. ${ }^{42}$ In order for the invalidation to be successful, factual evidence must be adduced to show that the use of a trade mark as a name or a description is well-known and established not only in respect of the goods connected with the trade mark proprietor, but also with other identical goods not connected in trade with the proprietor of trade mark. Only a disclaimer, by the proprietor, of exclusive rights to the use of the trade mark in relation to goods in respect of which the mark is considered generic, can salvage the mark from being invalidated and deregistered. ${ }^{43}$

39 S. 18, T., S. 17, K. \& S. 19, U.

40 The corollary to this position is the permission under the law pursuant to which a trade mark proprietor's consent is not required for third parties to use a trade, provided that such use is a bona fide description of the character or quality of a third party's goods (S. 34 (ii), T., S. 11(b), K. \& S. 24(b), U.).

41 S. 18, K. \& S. 42, U.

42 i.e. S. 18, K. \& S. 42 , U.

43 Cf. S. 18(2) (b), K. \& S. 42(3) (b), U. 
c) Trade Marks based on a shape of the goods

aa) The Tanzanian Law

The Tanzanian law on trade marks does not signal the possibility of a shape mark being registered and protected. According to Section 19(b) T. "trade or service marks which consist solely of the shape or configuration of the goods, or the containers thereof" are excluded from those signs that may be registered and protected in Tanzania.

Even if the list of the signs that are capable of being graphically reproduced provided in section $2 \mathrm{~T}$. is open for other items constituting visible signs to be added; the fact that shapes are not specifically mentioned in the section signifies that shape as such cannot be registered under the Act. This conclusion is collaborated by the provisions of section 19(b) which specifically excludes shape per se from registration. However, one fact remains bare: shapes can be reproduced graphically as required under section 2 TMA; they can also acquire distinctiveness if used in relation to goods or services. Nevertheless, the effect of section 19 (b) TMA in relation to registrations is to make such distinctiveness legally valueless. By having such an effect, Article 19 (b) appears to deviate from the underlying objective of the trademark protection regime, which is to virtually protect a sign as long as such sign is capable of distinguishing goods of one undertaking from those of other. In addition, there is a risk that the provisions of Section 19(b) T. contravene Article 15(1) TRIPS pursuant to which any sign (including figurative elements) that is capable of identifying one's goods or services may be registrable. ${ }^{44}$

bb) The Kenyan and Ugandan laws

Both Kenyan and Ugandan laws legitimatise registration of shape marks. A mark as defined under the Kenyan Trade Marks Act includes a distinguishing guise. ${ }^{45}$ The distinguish guise in the sense in which it is employed in the Act refers to the shape or configuration of containers of the goods applied in relation to particular

44 Regarding the signs capable of being registered as trade or service marks in Tanzania including shape marks see JACONIAH, J., "The Requirement for Registration and Protection of Non-Traditional Trade Marks in the European Union and in Tanzania", 40(7) IIC 756 et seq. (2009).

45 S. 2(1), para. $7, \mathrm{~K}$. 
goods. ${ }^{46}$ The Kenyan Industrial Property Office has offered a guidance as to which items may be regarded as distinguishing guises:

A distinguishing guise identifies the unique shape of a product or its package. If for example you manufactured a chocolate moulded to look like a rabbit, you might want to register the rabbit shape as a trade mark a distinguishing guise. ${ }^{47}$

On its part, the Ugandan law allows registration of shape marks subject to general and specific requirements. In keeping with the general conditions, shape marks are only registrable if they can distinguish goods ${ }^{48}$ and are capable of being used in relation to those goods in printed or other visual representations. ${ }^{49}$ Specific registration requirements concerning registration of shape marks under the Ugandan law are stipulated under Section 23(5), U. The effect of the provisions of this section is to deny certain shapes a legal capability of being registered as trade marks for goods even where such registration may not be refused based on the general registrability requirements. In this regard, the Ugandan law clarifies that the "shape that results from the nature of goods; the shape of the goods that are necessary to obtain a technical result; or the shape that gives substantial value to the goods" cannot be registered as a trade mark relating to goods. ${ }^{50}$

\section{d) Other absolute grounds}

aa) Under the Tanzanian Law

In addition to the category of marks described above, the Tanzanian law excludes from registration as a trade mark other types of marks. For instance, any sign the use of which is likely to contravene the good morals of the society cannot be registered. Similar prohibition extends to deceptive marks or those which are likely to "cause confusion as to the nature, geographical or other origin, manufacturing process, characteristics or suitability for their purpose, of the goods or services concerned" ${ }^{51}$ Section 19(c), T., excludes from registration state emblems, official hallmarks, and emblem of intergovernmental organizations. Thus, Section 19(c), T., aims to make the Tanzanian Trade and Service

47 <http://www.kipi.go.ke/index.php/trademarks> (status: 30 July 2012).

48 S. 4(1), U.

49 Cf. S. 1(2), U.

$50 \quad$ S. 23(5), U.

51 Cf. S. 19(a), T. 
Marks Act compliant with the provisions of Article $6^{\text {ter }}$ of the Paris Convention, which require Member States to incorporate similar exclusions in their municipal trade mark laws. On its part, Section 19(d), T., excludes registration of "trade or service marks which constitute reproductions in whole or in part, imitations, translations or transcriptions, liable to create confusion of trade or service marks and business or company names which are well known" in Tanzania and belong to third parties. The provisions of Section 19(d), T., implement Article 6bis of the Paris Convention, which requires Member States to protect well-known trade marks.

bb) Under the Kenyan and Ugandan laws

The Kenyan and Ugandan laws contain an all-embracing formulation capable of capturing almost every type of marks prohibited from registration in Tanzania by virtue of Sec. 19, T. In this regard, Sec. 14, K. makes it unlawful:

[To] register as a trade mark or part of a trade mark any matter the use of which would, by reason of its being likely to deceive or cause confusion or otherwise, be disentitled to protection in a court of justice, or would be contrary to law or morality, or any scandalous design.

Formulation of this provision leaves much to be desired: the use of the phrase "be disentitled to protection in the court of justice" is a puzzle, which every prospective trade mark registrant has to unfold in order to determine whether his trade mark qualifies for registration. A more specific embodiment such as that which is enshrined in Sec. 23(1), U. ${ }^{52}$ would be needed in Sec. 14, K. for the precision and predictability of the Kenyan trade mark regime.

\section{Relative grounds}

a) Prior registered trade mark

The trade mark laws of all the three EAC partner states under discussion refuse trade mark registration if a third party successfully claims that he is the proprietor of a trade mark and that the applicant has submitted to the trade mark

52 S. 23(1), U. provides that: "The registrar shall not register as a trademark or part of a trademark any matter the use of which would be likely to deceive or would be contrary to law, morality or any scandalous design". 
registrar an application for the registration of an identical or confusingly similar trade mark. ${ }^{53}$

\section{b) Prior unregistered trade mark}

The law puts it tritely that "no person shall be entitled to institute any proceedings to prevent or to recover damages for the infringement of an unregistered trade or service mark". ${ }^{54}$ Nevertheless, unregistered trade mark rights may be invoked to prohibit registration of another trade mark. Under the Tanzanian law, for instance, unregistered rights may constitute relative grounds for trade mark refusal. Thus, a proprietor of earlier unregistered trade mark, may formally base on his rights to oppose registration of a trade or service mark. ${ }^{55}$

Unregistered trade mark rights are not stipulated under the Kenyan and Ugandan laws as relative grounds for the refusal of trade mark registration, but such rights may be enforced, under the tort of passing off, against any person attempting to use a mark identical or confusingly similar to those rights. ${ }^{56}$ One may question, whether a proprietor of unregistered trade mark in Kenya or in Uganda can substantiate his rights to prohibit registration of identical or confusingly similar trade marks. The fact that the law acknowledges a possibility of unregistered rights being enforced would be interpreted to mean that the trade mark registrar is likely to refuse a trade mark registration in respect of which he has a reason to believe that such a trade mark is likely to be challenged immediately after the grant of the registration.

56 S. 5, K. \& S. 35, U. See also S. 30, T., for similar position under the Tanzanian law. The judiciary in the East Africa has offered a legal construction of the tort of passing off: "To succeed in any action alleging passing off (which is an infringement of the legal principle that no man may sell his goods as those of another) a plaintiff must prove three things namely (a) that he has acquired a reputation or good will connected with the goods or services and that such goods or services are known to buyers by some distinctive get up or feature; (b) that the defendant, has whether intentionally or not, made misrepresentation to the public leading them to believe that the defendant's goods are the plaintiff's; and (c) that the plaintiff has ............damage because of the erroneous belief engendered by the defendant's misrepresentation" (SUPA BRITE Ltd v PAKAD Enterprises [1970] 2 EA563. The case is also quoted in a ruling of the HCK (Commercial Court of Kenya (CCK) registry), Civil Suit 314 of 2006, Match Masters Ltd v Rhino Matches Ltd [2006] eKLR 5). 
c) Business or company name

The Kenyan and Ugandan trade mark laws do not provide an express stipulation to the effect that business or company names are relative grounds for trade mark refusal. However, the Tanzanian law $^{57}$, provides as a relative ground for refusing an application for trade mark registration "where the trade or service mark resembles in such a way as to be likely to deceive or cause confusion, with business or company name already used in Tanzania by a third party".

d) Trade mark application filed in the name of agent

A trade mark application may be denied registration, if it is proved that the trade mark concerned is registered abroad and that the person seeking registration is just an agent of the proprietor of the trade mark. ${ }^{58}$

\section{Trade mark opposition and cancellation procedure}

The national trade mark laws grant the High Courts ${ }^{59}$ of the EAC Partner States with exclusive powers to deal with disputes relating to a decision of the trade mark registrar to register a particular trade mark. In this regard, the law allows interested parties to oppose registration of a particular national trade mark by citing some absolute and/or relative grounds for trade mark refusal. ${ }^{60}$ Oppositions are normally dealt with by the registrar manning the national trade mark office. An appeal against the registrar's decision on the registrability of a particular trade mark may be lodged before the High Court of a respective Partner State. ${ }^{61}$ Trade mark cancellation proceedings ${ }^{62}$ may be instituted before the registrar in a national trade mark office or before the High Court. ${ }^{63}$ Should a

57 i.e. Section $27(2)(b), T$.

58 S. 27(2) (c), T.

59 Article 108 of the Constitution of the United Republic of Tanzania of 1977 (as amended) establishes the High Court of Tanzania. Article 60 of the Constitution of Kenya [R.E. 2009] establishes the Kenyan High Court. Article 138 of the Constitution of Uganda [R.E. 2000] establishes the Ugandan High Court.

60 These grounds are outlined in section C (II) of this chapter.

61 Cf. SS. 27(6) \& 48, T., S. 31(11), K. \& S. 12, U. See also S. 2, T., S. 2, K. \& S. 1, U., which define the term "court", as used in the Acts, to mean the "High Court".

62 Cancellation proceedings may be realised either through revocation or invalidation proceedings ( $c f$. section $\mathrm{G}$ of chapter 4 ).

63 Cf. S. 36, T., S. 35 K. \& SS. 50 \& 63 U. 
person opt to submit his cancellation claim before the registrar, the registrar may (if he so wishes) refer the suit to the High Court irrespective of the stage of the proceedings. This is especially the case if, in the course of the proceedings, the registrar encounters a question of law in respect of which, in his opinion, the court is better placed to provide a proper solution than the registrar would be. ${ }^{64}$ Sometimes the registrar may not refer the cancellation suit as aforesaid, but may enter a judgment on the merits of the suit accompanying it with a mandatory, express statement indicating that the judgment is open for an appeal to the High Court. ${ }^{65}$ Once trade mark proceedings are properly instituted before the High Court, the national trade mark registrar must be afforded an opportunity to be heard, particularly where the effects of the Court's decision is to change the status of the trade mark registration as had been recorded in the national register. ${ }^{66}$ Usually, the status of a trade mark registration may be changed through cancellation. ${ }^{67}$

\section{E. Infringement of a registered trade mark}

The trade mark laws of Tanzania, Kenya and Uganda demonstrate some similarities in the way they address issues pertaining to trade mark infringement such as the scope of trade mark protection and the limitation to the trade-markproprietor's exclusive rights.

\section{Scope of protection}

Trade mark infringement is categorised as a tort of strict liability. Hence, liability attaches irrespective of whether the defendant intended to infringe the plaintiff's trade mark or not. ${ }^{68}$ Thus, where a validity of a trade mark registered in one of the EAC partner states is confirmed, an assumption is cast in favour of the trade

64 Cf. SS. $49 \& 55$, T., S. 53, K. \& S. 63, U.

$65 \quad C f$. S. 55, T., S. 53 K. \& S. 63 U.

66 Cf. SS. $52,53 \& 54$, T., S. 50 K. \& S. 61 U.

67 The term "alteration and/or rectification of the register" employed in the national trade mark laws of the EAC Partner States (cf. SS. 36 \& 39, T., S. 37, K. \& SS. 45, 46 \& 61, U.) when referring to circumstances under which the status of a register with respect to trade mark registration may be changed is more general and encompasses the term "cancellation".

68 CCK, 10 May 2001, Case Number: 746/98 Pharmaceutical Manufacturing Co v Novelty Manufacturing Ltd [2001] 2 EA 521, 527 para. (c). 
mark proprietor that his trade mark registration has extended to him "the exclusive rights to the use of a trade or service mark in relation to any goods including sale importation and offer for sale or importation". ${ }^{69}$ The trade mark proprietor's exclusive rights are considered to be infringed where a third party not having the authority to use the proprietor's trade mark, uses in the course of trade or business, a sign which is identical or nearly resembles the trade mark considered to be infringed. Unless the use of an infringing sign is likely to deceive or confuse consumers as to the origin of the goods or services, the court cannot endorse infringement thereto. ${ }^{70}$ For that matter, it is imperative for the plaintiff to prove the similarity between the conflicting marks. ${ }^{71}$ This may be realised through consumers' testimony indicating the likelihood of confusion or deception. ${ }^{72}$ However, the testifying consumer is not entitled to say that the offending mark so nearly resembles the registered mark as to be likely to deceive or cause confusion. It falls within the court's competence to answer the question whether the infringing and the registered signs are similar and whether that similarity causes consumer confusion or deception. ${ }^{73}$ To discharge this duty, the "court has to wear the shoes of a common man, spread the marks before it and ask itself whether there are resemblances between the two which would make it pick a product which was not intended but the opposite". ${ }^{74}$

\section{Use of a mark as a trade mark}

A registered trade mark can only be infringed if the infringer uses an infringing sign as a trade mark. ${ }^{75}$ No infringement can be imputed to a third party who uses a trade mark in a way that does not cause consumers to associate the third party's products with the proprietor of that trade mark. This is opposed to a situation in which a third party uses a mark, "upon the goods or in physical relation thereto,

69 S. 31, T. See also SS. 7(1) \& 8(1), K. and S. 36, U. See also CAK, 17 October 1997, Case Number: 235/96 Samaki Industries (Nairobi) Ltd v Samaki Ltd (K) Ltd (2) [199598] 2 EA 366, 373 para. (e).

$70 \quad$ S. 32(1) (a), T. \& S. 7(1), K.

71 HCU, 17 February 1964, Aktiebolaget Jonkoping-Vulcan v East African Match Co. Ltd [1964] 2 ALR Comm. 176, at p. 183 (lines 30-34).

72 Cf. CCK, 10 May 2001, Case Number: 746/98 Pharmaceutical Manufacturing Co $v$ Novelty Manufacturing Ltd [2001] 2 EA 521, 527 para. (f).

73 HCU, 17 February 1964, Aktiebolaget Jonkoping-Vulcan v East African Match Co. Ltd [1964] 2 ALR Comm. 176, at p. 183 (line 34) and at p. 184 (line 26).

74 HCT, Tanzania Breweries Ltd v Kibo Breweries and Kenya Breweries, Civil Case No. 34 of 1999 (Dar Es Salaam Registry (unreported)), para. 16.

75 S. 32(1) (a) (i), T. \& S. 7(1) (a), K. 
or in relation to services, or in an advertising circular or other advertisement issued to the public", in a way that makes the consuming public believe that the goods or services being marketed or advertised come from the proprietor of a trade mark or any other person authorised by him. ${ }^{76}$

\section{The use of business or company names}

Trade mark infringements may be affirmed, pursuant to Tanzanian law, against a person who uses a business or company name identical or closely resembling a registered trade mark. ${ }^{77}$ Viewed critically, this strengthened protection a registered trade mark enjoys may not be justified in every circumstances. It is a well-established, general principle of trade mark law that as long as the proprietor prohibits third parties from using his registered trade mark in relation to identical or confusingly similar goods he will be justified. ${ }^{78}$ By analogy, the Tanzanian law should be interpreted to mean that the use of a trade or a company name cannot constitute trade mark infringement, unless such use is in respect of the goods and/or services which are similar or identical to those for which the trade mark is registered. However, insofar as the exception to the above general rule is concerned, the Tanzanian law may be justified if the infringed trade mark is a well-known or famous mark. ${ }^{79}$ This position is not different from that under the Kenyan and Ugandan laws.

\section{Trade mark with reputation}

Both Kenyan and Ugandan laws do not enshrine a specific provision for the protection of trade mark with reputation. ${ }^{80}$ On its part, the Tanzanian law provides an open-ended pigeon-hole in which any use of a sign resembling a registered trade mark with reputation would be enjoined by the proprietor,

76 S. 32(1) (a) (i), T. \& S. 7(1) (b) \& (c), K.

77 Cf. S. 32(1) (a) (i), T.

78 Cf. S. 20(1), T.

79 Well-known and/or famous trade marks may be infringed by the use of similar or identical mark for dissimilar goods or services.

80 However, a general stipulation under the Kenyan law may be invoked to protect marks with reputation: Restriction is imposed against a third party who uses a sign, which is identical to or closely resembling a registered trade mark, in a manner that is likely to cause injury or prejudice to the proprietor of the registered trade mark $(C f . \mathrm{S}$. 7(1) (d), K.). 
irrespective of whether the goods or services marketed under the sign and the registered trade mark are same. According to the relevant Section of the law, any use of sign by a third party who has not secured a permission from the owner of the registered trade mark will be enjoined if such use is likely to impair the distinctive character or acquired reputation of a registered trade mark, unless the infringing sign and the registered trade mark are not identical or there is no close resemblance between them. ${ }^{81}$

\section{Limitation to the exclusive rights}

\section{Use of one's own name}

Trade mark laws of the EAC partner states entitle any person to the use of "his own name, or of the name of the geographical location of his business, or of the name of any of his predecessors in business" in relation to goods or services, even where another person owns a registered trade mark similar to the third party's name. ${ }^{82}$ However, such use of the name by the third party cannot be justified unless it is a bonafide use. ${ }^{83}$

\section{Descriptive use of a trade mark}

It is lawful for marketers to describe the quality or characteristics of their goods using a trade mark irrespective of whether the trade mark owner has consented to the use. This is however a rebuttable presumption: A person resorting to a descriptive use of the mark must ensure that the use does not influence the public to think that the goods under description come from the proprietor of the trade mark, or that there is any connection whatsoever between the goods under description and the proprietor of the trade mark. ${ }^{84}$

81 Cf. S. 32(2), T.

82 S. 34 (i), T., S. 11 (a), K. \& S. 24 (a), U.

83 Cf. S. 34 (i), T., S. 11 (a), K. \& S. 24 (a), U. It has been held in this regard that ".......A man is entitled to trade in his own name provided he does what is reasonable necessary to distinguish his business from that of another person of the same name" (CCK, Civil Suit 314 of 2006, Match Masters Ltd v Rhino Matches Ltd [2006] eKLR 6. 


\section{Honest concurrent use of trade marks}

Under certain special circumstances, the law allows two or more identical or confusingly similar trade marks to co-exist in the trade mark register. The conditions for such co-existence are met if two persons, who are not connected in business, adopt and use an identical trade mark in relation to identical or confusingly similar goods or services. The adoption and the use of the mark must nevertheless be concurrent and in an honest way. ${ }^{85}$ The manner, in which trade mark co-existence is possible, in a legal sense, may be depicted by a hypothetical case. Suppose that PATEL adopts and uses a trade mark, say DRYTOUGH, in relation to building-construction materials, but does not apply for registration of his trade mark. Assume further that RODGERS, not knowing the existence and the use of PATEL's unregistered trade mark adopts and uses the trade mark "DRYTOUGH" in relation to the same goods in respect of which PATEL uses the mark. After some time, RODGERS applies for the registration of his trade mark. The trade mark examiners, being unaware of PATEL's earlier adoption and use of the mark, issue RODGERS with a certificate of registration for the DRYTOUGH mark. In the circumstances, PATEL may get his trade mark registered without however invalidating RODGERS' registration. This may, therefore, be seen as a limitation to the principle of exclusivity of trade mark rights described in section $\mathrm{E}$ (I) of this chapter. ${ }^{86}$

On a case variation, RODGERS has no right to restrict PATEL from using DRYTOUGH mark even where PATEL does not seek registration of the mark. RODGERS would only succeed in excluding PATEL from using the mark if PATEL is unable to prove that he, or his predecessor in title, has been using a trade mark from the date anterior to the first use or to the registration of the registered trade mark in question. ${ }^{87}$

\section{Exhaustion of trade mark rights}

Exercise of trade mark rights by proprietors is subject to the doctrine of trade mark exhaustion. The tenet of trade mark exhaustion refers to a scenario under which a trade mark proprietor, having exercised some exclusive rights he/she enjoys in relation to his/her trade-marked goods, is taken to have relinquished those rights with the consequences that third parties can thereafter commercialise 
the goods concerned without requiring a trade-mark proprietor's permission. ${ }^{88}$ However, if trade mark rights have not yet been exhausted the proprietor's exclusive rights protected in a certain territory will remain intact. In the circumstances, the trade mark owner will have a right to "stop goods at the borders of the respective territory bearing an identical mark to his own". 89

The doctrine of trade mark exhaustion, in the context of national trade mark laws of the EAC Partner States, is discussed in detail in section C (I) (2) to (4) of chapter 3. The principle of regional trade mark exhaustion underlying the EU trade mark law is outlined in section $\mathrm{C}$ of chapter 6 .

\section{Duties in relation to a registered trade mark}

\section{Renewal of registration}

Trade mark legislations of EAC partner states require as a condition for continuation of the validity of trade mark after the expiry of the initial registration term of registration that the said registration be renewed. Under both Tanzanian and Ugandan trade mark legislations, trade mark registrations enjoy an initial term of seven years with the possibility of renewal of the registration for further terms, of ten years each, commencing from the date of expiration of the initial registration. ${ }^{90}$ Under the Kenyan law, trade marks are initially registered for a term of ten years with a possibility of extension of the registration for further terms of ten years each. ${ }^{91}$

\section{Obligation to use a registered trade mark}

Trade mark laws of the EAC Partner States devise a mechanism to avoid trade mark system being used as a means of granting a monopoly in words and other signs without those words and signs actually being used in relation to goods or services. For this reason, trade and service marks are protected in Tanzania and

88 Cf. BAINBRIDGE, D., "Intellectual Property" (7th ed.) 827 (Pearson Education Limited, Harlow 2009).

89 PAGENBERG, J., "The Exhaustion Principle and "Silhouette" Case", 30(1) IIC 19, 23 (1999).

90 S. 29 (1) \& (2), T. \& S. 21, U.

91 S. 23 (1) \& (2), K. Before the amendment of the Kenyan Trade Marks Act in 2002, the initial trade mark registration term was 7 years and subsequent terms were 14 years each. 
in Uganda subject to the condition that such marks be put to genuine use within the maximum period of three years from the date of registration of the marks and from the date of renewal of the registration of the marks concerned. ${ }^{92}$ The Kenyan trade mark legislation requires a trade mark to be put to genuine use within any five years. ${ }^{93}$ Any trade mark which is not put to genuine use in accordance with the foregoing conditions is likely to be deregistered upon a request of a third party.

\section{F. International trade mark registration}

Legal protection of trade marks in the EAC Partner States does not accrue automatically. A formal trade mark protection is dependent upon a mark concerned being registered as a national trade mark in an individual Partner State. ${ }^{94}$ There are different ways through which such registration may be secured. The trade mark proprietor has to decide whether he wants his trade mark application to be governed solely by the national law or by both national law and the law governing international or regional registration of trade marks. Protection, in the EAC, of a trade mark via regional trade mark registration scheme is available under the regime established and managed by the African Regional Intellectual Property Organization (ARIPO), ${ }^{95}$ whereas protection via an international registration system is conducted pursuant to the procedure and requirements outlined in the Madrid Agreement and the Madrid Protocol. ${ }^{96}$

92

93

94

95
S. 35(1), T. \& 46, U.

S. 29(1), K.

However, unregistered trade mark rights may, exceptionally, be enforced ( $c f$. Section C (II) (2) (b) of this chapter).

$C f$. the Lusaka Agreement on the creation of an Industrial Property Organization for English-Speaking Africa of December 1976, as amended by the administrative council of ARIPO on December 10, 1982, December 12, 1986 and November 27, 1996, and as amended by the Council of Ministers on August 13, 2004. The Lusaka Agreements empowers ARIPO to enact some Protocols that are necessary to define the functions and powers of ARIPO in specific fields of intellectual property rights. Thus, ARIPO's competence in relation to issues pertaining to trade mark registration are defined by the Banjul Protocol on Marks adopted by the Administrative Council at Banjul, The Gambia on November 19, 1993 and amended on November 28, 1997, May 26, 1998, and November 26, 1999 and as amended by the Council of Ministers on August 13, 2004.

The system is governed by two international treaties, namely, the Madrid Agreement Concerning the International Registration of Marks "adopted in Madrid in April, 1891 and the Protocol Relating to the Madrid Agreement adopted in Madrid on 27 June 1989 and came into force on 1 April 1996. 
Tanzania and Uganda ratified the Banjul Protocol on Marks and hence are fully bound by it. Kenya has not yet ratified the Protocol but enshrined a provision in the Trade Mark Act implementing the Protocol. According to the implementing provision, the normative order enshrined in the Kenyan Act is superior to the stipulations in the Banjul Protocol. ${ }^{97}$

Kenya has ratified both the Madrid Agreement and the Protocol thereto (hence fully bound by them), ${ }^{98}$ while Tanzania and Uganda have not. Whereas applicants for international trade mark registrations may only designate Kenya, such designation may have impact on the internal market in case a regional trade mark regime is established in the EAC.

\section{G. Concluding remarks}

The discussion in the Chapter has brought to light a number of discrepancies and/or some weaknesses inherent in the national trade mark laws of the EAC Partner States. In connection with the absolute grounds for trade mark refusal, the concept of distinctiveness under the Kenyan and Ugandan laws is addressed differently from the stipulation under the Tanzanian law, the root cause being the partition of the Kenyan and Ugandan trade mark register into two parts (i.e., part $\mathrm{A}$ and part B). While a generic trade mark cannot be legally registered under the Kenyan and Ugandan laws, the Tanzanian trade mark legislation does not contain any stipulation in this respect. Regarding the relative grounds for trade mark refusal, unregistered rights may be invoked to oppose registration of a trade mark in Tanzania and in Uganda, but such rights cannot constitute a ground for refusing or opposing a trade mark application in Kenya, notwithstanding the fact that infringement of such rights may be redressed under the tort of passing off.

Some other notable substantive differences are the terms of trade mark registration and the renewal of the registration. Important as well is the difference in the time limit with respect to putting a registered trade mark to genuine use.

Finally, the chapter has revealed that the differences exist with respect to systems of international trade mark registrations with effect in the EAC Partner States.

As a condition for attaining a common EAC trade mark regime, the differences and weaknesses of the national trademark systems of the EAC Partner States identified in this chapter must be addressed.

97 See S. 40D (3), K.

98 See S. 40B, K. 


\section{Chapter 3: The Free Movement of Trade-marked Goods in the East African Community}

\section{A. Introduction}

This chapter analyses the principle of free movement of branded goods in relation to the EAC Common Market. In this regard, three documents, namely, the Treaty for the establishment of the East African Community and the Protocols $^{99}$ establishing the East African Community Common Market and the Customs Union are identified as the main legal basis for the free movement of goods in the EAC Common Market. The extent to which these laws support the principle of free movement of branded goods is subjected to a critical scrutiny. Following some general considerations addressing the way in which trade mark proprietors may invoke their nationally registered trade marks to obstruct free movement of goods and whether such practice may be justified by virtue of the functions of trade marks, the principle of trade mark exhaustion, and the principles of international law; the Chapter analyses different forms of trade mark exhaustion, pointing out the specific form(s) of exhaustion employed in the EAC Partner States.

\section{B. The Principle of free movement of goods}

\section{Legal basis}

\section{The EAC Treaty (EACT)}

Article 76(1) EACT establishes a Common Market among the Partner States with a primary objective of achieving a single market in the EAC. ${ }^{100}$ A Common Market is generally ascribed to an area without frontiers in which free movement

99 According to the delineation offered in Article 1 East African Community Treaty (EACT), a protocol is any agreement among the EAC Partner States that supplements, amends or qualifies the EACT.

100 See also Articles 2(2) and 5(2) of the EACT, which anchor the desire of the Partner States to establish an EAC Common Market. 
of goods is, inter alia, ensured. ${ }^{101}$ In the specific context, Article 1 EACT portrays the EAC Common Market as the Partner States' markets integrated into a single market in which there is a free movement of capital, labour, goods and services.

\section{The EAC Common Market Protocol (CMP)}

Article 76(1) of the EACT only demonstrated the desire of the EAC Partner States to establish a Common Market. The concrete establishment of such Market was dependent on the conclusion of a relevant Protocol by the Partner States pursuant to Article 76(4) of the EACT. A Protocol on the establishment of the EAC Common Market was approved on 1 November 2009 and came into force on 1 July $2010 .{ }^{102}$ The Protocol stipulates the realisation of accelerated economic growth and development through attainment of various freedoms ${ }^{103}$ such as the free movement of goods as the impetus for the establishment of the Common Market. ${ }^{104}$

\section{The EAC Customs Union Protocol (CUP) $)^{105}$}

Article 6(1) of the CMP links the free movement regime to the Customs Union Protocol. In this regard, the "free movement of goods between the Partner States shall be governed by Customs Laws of the Community" as stipulated in Article 39 of the CUP. Article 39(1) (a) to (f) of the CUP elaborates that the Customs law of the Community consists of the relevant provisions of the EAC Treaty; the CUP itself; regulations and directives made by the EAC Council; case law; Statutory instruments enacted by the EAC legislative Assembly; and the relevant principles of international law.

In relation to relevant principles of international law, an attempt is made, in section C (II) of this chapter, to find out whether provisions of the Agreement on Trade-Related Aspects of Intellectual Property Rights (TRIPs) and the General

101 M.A. Consulting Group, "Study on the Establishment of an East African Community Common Market", (submitted to the EAC on 28th August 2007), at p. 44.

102 Establishment of the EAC Common Market is viewed as "a transitional stage to and an integral part of the Community" ( $c f$. Para 3(a) of the Preamble to the CMP).

103 These freedoms are enumerated in Article 2(4) of the CMP.

$104 C f$. Article 4(2) and Para 6 of the Preamble to the CMP.

105 The Protocol on the establishment of the East African Customs Union came into force on 1 July 2006. 
Agreement on Trade and Tariffs (GATT) ${ }^{106}$ may be invoked to facilitate free movement of branded goods in the EAC Common Market.

\section{Trade mark rights in the Common Market}

Trade marks are essential aspects for the proper functioning of any Common Market. Practical experience shows that unless a special trade mark regime is established to cater for the interests of the common market, national trade mark regimes of the cooperating States will encourage imposition of some restrictions on the free movement of branded goods. ${ }^{107}$ While the Common Market among the EAC Partner States has been established, a common trade mark regime that may substantially contribute to proper functioning of such market has not yet been put in place. The absence of such regime means that the exercise of independent national trade mark rights is likely to come into conflict with the Common Market's objectives of ensuring free movement of goods.

The national trade marks characterising the EAC trade mark protection regime are not only territorial but also independent of each other. ${ }^{108}$ It is, thus, lawful for a trade mark proprietor to apply for registration of a single trade mark for identical goods in different countries. ${ }^{109}$ In the circumstances, a trade mark proprietor owning a trade mark registered in Tanzania, Kenya and Uganda has some legal power not only to control the initial marketing, but also the further commercialisation, of the trade-marked goods and thereby dissecting the EAC Common Market into national markets. Goods marketed in one of these countries may not lawfully be re-imported in any of the rest countries. This legal possibility stands in contradiction with the noble purpose of the free movement principle enunciated in the EAC Treaty and the Protocols thereto.

106 The General Agreement on Tariffs and Trade of 30 October 1947 forms part of the General Agreement on Tariffs and Trade 1994 ("GATT 1994").

107 Cf. chapter 6 which describes this problem in relation to the European Common Market.

108 Regarding the territoriality principle of national trade marks $c f$. ECJ, Case C-9/93 IHT Internationale Heiztechnik GmbH v Ideal-Standard GmbH [1994] ECR, I-02789, para. 22.

109 Cf. STUART, M., "The Function of Trade Marks and the Free Movement of Goods in the European Economic Community", 7(1) IIC 27, 34 (1976). 


\section{The Common Market Protocol}

One of the items of evidence that national trade mark laws may be invoked to restrict free movement of branded goods can be deduced from Article 29 of the CMP. The basic purpose of the Article is to guarantee protection of cross-border investments in each of the Partner States. Cross-border investment, as used in the Article, refers to "any investment by a national of a Partner State in the territory of another Partner State". 110 The term "investment" is employed in the Article to refer to "any kind of asset owned or controlled by an investor of a Partner State in another Partner State in accordance with the national laws and investment policies of that Partner States". 111 Intellectual property rights are mentioned as a possible investment area pursuant to the relevant national laws. ${ }^{112}$ In view of the foregoing provision, EAC nationals ${ }^{113}$ are entitled to have their intellectual property rights created and protected in accordance with the relevant laws in the Partner State(s). ${ }^{114}$ Viewed in this sense, Article 29 of the CMP allows circumvention of the principle of free movement of goods: It recognises the independent national trade mark regime of the partner states - a regime that facilitates multiple registrations of a single trade symbol as a national trade mark in different Partner States - without providing an alternative regime that is necessary to encounter the challenges, which the national trade mark systems pose on the EAC Common Market. Accordingly, Article 29 of the CMP contradicts the CMP's general aim to establish a single market in which a stable regime for the free movement of goods is guaranteed. This mischief cannot be avoided, unless the Article is given a broad, purposive interpretation in the light of other provisions of the CMP, particularly Articles 33 and 36. While Article 33 articulates some prohibited business practices, Article 36 enshrines some provisions relating to consumer protection.

In relation to prohibited business practices, Article 33(1) of the CMP decrees that EAC Partner States "shall prohibit any practices that adversely affect free trade". A Partner State enacting a piece of legislation that allows trade mark rights to be invoked to restrict free movement of goods fails to fulfil its duties under Article 33(1) of the CMP. Reliance on that law cannot be justified, unless

110 Article 29(4) of the CMP.

111 Article 29(4) of the CMP.

$112 C f$. Article 29(4) (f) of the CMP.

113 Investor in the context of Article 29(4) of the CMP means a national of a Partner State who has made an investment in the territory of another Partner State.

114 The legal stipulation in Article 29 of the CMP may also be enforced based on Article 3(2)(a) of the CMP, which requires Partner States to avoid discrimination of nationals of other Partner States on grounds of nationality. 
it is the only reasonable means to enforce the proprietor's legitimate interests. ${ }^{115}$ Disappointingly however, Article 33(1) seems to be toothless and hence incapable of enforcing the foregoing conclusion. ${ }^{116}$ Article 33 aims to capture some specific behaviour, among which unilateral conducts are excluded unless they relate to the abuse of dominant position. ${ }^{117}$ This implies that, under certain circumstances, proprietors are free to rely on their trade mark rights to obstruct free movement of goods irrespective of whether such reliance is necessary for the trade mark to perform its functions or for the proprietor to realise his other legitimate interests such as the right to be the first to sale the trade-marked goods.

The practice of restricting free movement of goods on the pretext of protecting trade mark rights as explained above is contrary to the principle of consumer protection stipulated in Article 36 of the CMP. The Article requires EAC Partner States to create conducive environment for the realisation of fair and effective competition as a condition precedent "to provide consumers with greater choice among goods and services at the lowest cost". 118 The foregoing provisions foster free trade, the spirit of which may be realised through parallel importation. ${ }^{119}$ By allowing parallel imports, Article 36 tends to outlaw any restrictions imposed on trade-marked goods in a way that cannot be justified by the principles of trade mark law. ${ }^{120}$ However, unless the EAC Council issues a directive or regulation interpreting the provisions of Article 36 in line with the foregoing interpretation,

115 A clear description of these interests is offered in section C (I) of this chapter.

116 Article 33 of the CMP, basically incorporates competition rules. The extent to which these rules may be based upon to facilitate free movement of trade-marked goods in the Common Market is discussed in detail in Chapter 6 in the context of the EU Common Market.

117 The Article is drafted to outlaw business practices emanating from agreements between undertakings (including decisions by undertakings and concerted practices) which may affect trade between Partner States (and which have as their objective or effect the prevention, restriction or distortion of competition within the Community); mergers leading to the creation or strengthening of dominant positions, and the abuse of a dominant position by one or more undertakings within the meaning of Article 33(2) (a) to (c) of the CMP.

118 Article 36(1) (b) of the CMP.

119 "Parallel imports of genuine goods promote free trade, encourage competition and exert a salutary pressure for price levelling" (CORREA, C. M. \& YUSUF, A. A. (eds.),

"Intellectual Property and International Trade: The TRIPS Agreement" (2nd ed.) 20 Kluwer Law International, Alphen aan den Rijn, 2008)).

120 The principles of trade mark law relevant for the free movement of branded goods are discussed in section $\mathrm{C}(\mathrm{I})$. 
trade mark proprietors will still be able to circumvent the free movement principle in relation to branded-goods. ${ }^{121}$

\section{The Customs Union Protocol}

The EAC assumes, pursuant to Article 6 of the CPM, that the provisions of the CUP contain a sufficient, appropriate legal force for the regulation of the free movement of goods in the Common Market. ${ }^{122}$ Proponents of this assumption have put forth an argument that the legal regime for the elimination of internal tariffs and non-tariff barriers endorsed in the Customs Union Protocol was meant to facilitate the free movement of goods. ${ }^{123}$ While this assumption has a scintilla of truth, it is doubtful whether the regime has been tailored to the needs of the free movement of intellectual-property-imbedded goods: Tariffs are likely to affect the free movement of tangible goods, whereas non-tariff barriers are capable of affecting the free movement of both tangible and non-tangible goods including intellectual property rights. The question whether the EAC policy makers have interpreted the abolition of non-tariff barriers as a conduit pipe for the regulation of the free movement of trade-marked goods deserves an analysis.

Article 13 of the CUP requires the EAC Partner States to eliminate "non-tariff barriers to the importation into their respective territories of goods originating in the other Partner States". The term "non-tariff barriers" is operationally employ-

121 Enforcement of Article 36 of the CMP is done in accordance with the directives and regulations issued by the EAC Council (Article 36(2)).

122 Specific evidence of this assumption is in the final report of the study for the establishment of the EAC Common Market where it is contended that the free movement of goods "has been effectively secured under the Customs Union Protocol" (cf. M.A. Consulting Group, "Study on the Establishment of an East African Community Common Market", (submitted to the EAC on 28th August 2007), at p. 45. In this regard, it has been argued that the formation of the EAC Customs Union did not follow the integration sequences laid down by trade theories according to which Customs Unions are customarily preceded by arrangements for Preferential Trade Area (PTA) and Free Trade Area (FTA); and superseded by a Common Market (CM) and finally Economic and Monetary Union (EMU) ( $c f$. M.A. Consulting Group, ibid., p. 10). This is supported by the contention that cooperation under the auspices of the Customs Union went beyond free trade in goods for it encompassed some areas of cooperation with relevance to Common Market such as free movement of persons, services and capital; cooperation in monetary and fiscal matters; coordination of macroeconomic policies; strengthening of the organs and institutions of the Community; and cooperation in sectoral areas (cf. M.A. Consulting Group, ibid., p. 22).

$123 C f$. M.A. Consulting Group, "Study on the Establishment of an East African Community Common Market", (submitted to the EAC on 28th August 2007), at p. 22. 
ed in the CUP to refer to "laws, regulations, administrative and technical requirements other than tariffs imposed by a Partner State whose effect is to impede trade". ${ }^{124}$ While the national trade mark laws of the EAC Partner States must be regarded, based on their capability to restrict free movement of goods, as a category of non-tariff barriers, the EAC policy makers' attention has hitherto not been drawn to this reality.

According to an EAC report released in 2007, intellectual property rights are not regarded among the factors that pose some dangers to the free movement of goods and which are supposed to be categorised as non-tariff barriers. ${ }^{125}$ This practical reality contradicts the EAC Partner States' agreement to report on existence of non-tariff barriers guided by the non-tariff barriers categorisation codes of the World Trade Organisation (WTO) among which intellectual property issues feature. ${ }^{126}$

\section{Possible solution to the mischief}

\section{Principles of trade mark law}

The potential of trade marks to impede free movement of goods "is primarily debated in the context of parallel importation, ${ }^{127}$ i.e. attempts made by trade mark proprietors to seal off national markets as an element in price discrimination strategy". ${ }^{128}$ The question that stems from the principles of trade

124 Article 1 of the CUP.

125 The prevailing view of the stake holders in the EAC regards the following as the leading forms of non-tariff-based impediments: police road blocks, standards, sanitary and phyto-sanitary requirements, customs procedures and documentation, etcetera cetera (cf.M.A. Consulting Group, supra, p. 17).

$126 C f$. IHIJA, S. N., "Monitoring Mechanism for Elimination of Non-Tariff Barriers" - a project undertaken on behalf of the East African Community \& East African Business Council in 2009 (see particularly p. 11)

$<$ http://www.eac.int/customs/index.php?option $=$ com_content\&view=article\&id=4:ntbsmonitoring-mechanism\&catid=3:key-documents\&Itemid=141> (Status: 30 July 2012).

127 "Parallel Importation occurs when an intellectual property owner or his licensee sells protected goods in one market under such circumstances that those goods can be purchased there for export and imported into another market for sale against the wishes of the intellectual property owner and in competition with similar goods enjoying equivalent protection in the second market" (HAYS, T., "Parallel Importation under the European Union Law" 1 (Sweet \& Maxwell, London 2004).

128 Cf. KUR, A. "Strategic Branding: Does Trade Mark Law Provide for Sufficient Self Help and Self Healing Forces?" in: GOVAERE, I. \& ULLRICH, H. (eds.), "Intellectual Property, Market Power and the Public Interest" 191 (P.I.E. Peter Lang, Brussels; New York 2008). The electronic copy of the publication under reference is available at 
mark law is whether the reliance on the national trade mark rights to impede free flow of goods to the scale of the entire EAC Common Market is legally justifiable. As a matter of principle, it is sensible to inquire whether such restriction on the free movement of goods is necessary for the trade mark concerned to perform its functions. Additionally, it is also logical to find out whether such restrictions would be justified on the basis of the principle of exhaustion - a principle that tends to describe the extent of trade mark proprietor's monopoly in relation to commercialisation of branded goods.

\section{Trade mark functions}

A trade mark protection regime is not a self-enclosed system but a system that involves "entire markets" - national and global - as a playground of marketers, manufacturers and consumers, just to mention but a few, and should for that matter be justified on various grounds. ${ }^{129}$ Thus, an array of functions a trade mark may possibly perform can be singled out: (1) to identify the actual physical origin of goods and services, (2) to guarantee the identity of the origin of goods and services, (3) to guarantee the quality of goods and services, (4) to serve as a badge of support or affiliation, and (e) to enable the consumer to make a lifestyle statement. ${ }^{130}$ This enumeration should not be regarded profound, but just as a suggestive "template" of guidelines for the assessment of specific issues of trade mark law. For the purpose of this chapter only two functions, namely, the guarantee of origin and quality, are detailed.

\section{a) Trade mark as a badge of origin}

A trade mark is primarily expected to identify the actual physical origin of goods and services. This function has been categorised by the ECJ as essential function of a trade mark. ${ }^{131}$ The ECJ has, however, clarified that a trade mark's function

$<$ http://ssrn.com/abstract=1311243> (Status: 30 July 2012).

129 PHILIPS, J., "Trade Mark Law: a Practical Anatomy" 22 (Oxford University Press, Oxford 2003).

130 A detailed analysis of these functions is made in PHILIPS, J., "Trade Mark Law: A Practical Anatomy” 23-27 (Oxford University Press, Oxford 2003).

131 ECJ, Case C-102/77, Hoffmann-La Roche \& Co. AG v Centrafarm [1978] ECR 01139, para. 7. Cf. also ECJ, Case C-487/07, L'Oréal SA and Others v Bellure NV and Others [2009] ECR I-05185, para. 58. 
is not confined to the actual origin of goods or services ${ }^{132}$ for it may also be used to distinguish different products or services of a single (origin) trade mark proprietor. $^{133}$

b) Trade mark as a guarantee of quality

Consumers are basically interested in the quality of goods rather than their trade origin. ${ }^{134}$ This view is in line with the opinion of Attorney General Ruiz-Jarabo Colomer who once remarked:

It seems to me to be simplistic reductionism to limit the function of the trade mark to an indication of trade origin.... Experience teaches that, in most cases, the user is unaware of who produces the goods he consumes. The trade mark acquires a life of its own, making a statement, as I have suggested, about quality, reputation and even, in certain cases, a way of seeing life. ${ }^{135}$

The consumer's decision to purchase the goods is dictated by previous experience. The trade mark's guarantee-of-quality function becomes self evident when the mark enables relevant consumers to identify the differences between the products or services that it designates from goods which come, or from services provided, from a different source and to develop an impression that all the "products or services that it designates have been manufactured, marketed or supplied under the control of the owner of the mark and that the owner is responsible for their quality". ${ }^{136}$ The consumer's mind can, therefore, reiterate, as Lord Mackenzie Stuart sums it up well, that "[t]his mark, this brand has always served me well in the past. Therefore I can rely on it once again". ${ }^{137}$

In view of the foregoing, a trade mark may be regarded as performing another sub-category of a guarantee-of-quality function, namely, to raise consumer's trust in relation to the goods or services. ${ }^{138}$ This becomes eminent when a trade mark has been developed to a level that attracts consumers' trust in it due to the

132 ECJ, Case C-487/07, L'Oréal SA and Others v Bellure NV and Others [2009] ECR I05185, para. 58.

133 FEZER, K.-H., "Markenrecht” (13th ed.) 81(Verlag C.H. Beck, Munich 2009).

134 TRITTON, G., "Parallel Imports in the European Community", A paper prepared for the Intellectual Property Institute - London, 1997.

135 ECJ, 12 November 2002, Case C-206/01, Arsenal Football Club plc v Matthew Reed [2002] ECR I-10273, para. 46.

136 ECJ, 5 March 2003, Case C-194/01 Unilever NV v OHIM (not reported in the ECR), para. 43. Cf. also ECJ, Case C-39/97, Canon [1998] ECR I-5507, para. 28.

137 STUART, M., "The Function of Trade Marks and the Free Movement of Goods in the European Economic Community”, 7(1) IIC 27, 31 (1976).

138 FEZER, K.-H., "Markenrecht” (13th ed.) 82(Verlag C.H. Beck, Munich 2009). 
assurance it has given them that the proprietor cannot betray this trust since he/she is economically interested in maintaining the value of the mark. ${ }^{139}$ In this regard, the consumer will say to himself: "I need not investigate the attributes of the brand I am about to purchase because the trade mark is a shorthand way of telling me that the attributes are the same as that of the brand I enjoyed earlier". ${ }^{140}$

The distinction between a trade mark's functions of identifying an actual, physical origin of goods or services or of guaranteeing that the goods or services are of a certain quality is very fine. From the point of view of the guarantee of quality function, trade mark binds the trade mark owner (as a brand exploiter) to his customers. On the other hand, the guarantee of identity of origin function "sees trade marks as a sort of buffer which stops competing businesses getting too close together". ${ }^{141}$ Analysed from a different point of view, this distinction would be seen just a matter of theoretical exercise that does not emulate the practical reality: If consumers are interested in origin of the goods or services it is normally because the origin imports an expectation about some quality of the goods or services concerned. ${ }^{142}$

c) Trade mark functions and markets compartmentalization

It is clear from section B (II) of this chapter that, in theory, a person may secure registration of a single trade mark in all EAC Partner States. It is also accentuated in the same Section that this kind of registration virtually provides a trade mark proprietor with a legal power to impose some constraints on the movement of his own goods from one national market to another. This necessitates an inquiry as to whether the trade mark proprietor's power to impede free movement of goods can be justified in view of trade mark functions.

139 DAVIS, J., "To Protect or Serve? European Trade Mark Law and the Decline of the Public Interest", 25(4) E.I.P.R. 180, 182 (2003).

140 LANDES, W. M. \& POSNER, R. A., "Trademark Law: An Economic Perspective" 30 J.L. \& Econ. 265, 269 (1987).

141 PHILIPS, J., "Trade Mark Law: A Practical Anatomy” 26 (Oxford University Press, Oxford 2003).

142 CORNISH, W.R. \& PHILLIPS, JENNIFER, "The Economic Function of Trade Marks: An analysis with Special Reference to Developing Countries”, 13(1) IIC 41, 43 (1982). 
A tenable argument premised on the position that a legal monopoly associated with a trade mark only serves to indicate the origin of the proprietor's goods and/or services may be advanced to the effect that reliance on trade mark rights to impede free movement of goods in the EAC Common Market, whereby such use is not necessary for the trade mark to perform the origin function, would be outlawed. Thus, it would be impossible for a single undertaking to seal off the national markets of the EAC Partner States based on multiplicity of trade mark registrations. Further commercialisation of the trade-marked goods would not be objected since the trade mark on the goods still genuinely indicates the proprietor as the source of the goods and not the parallel importer who gets access to the goods after the initial commercialisation by the owner of the trade mark.

However, there is a motivation to circumvent the guarantee of origin function: The practice of obtaining different registrations in various States for a single trade mark and for the same goods and/or services impacts positively on the proprietor's business since he can sell identical goods at different prices in different Partner States - a business scheme whose determinant factors may, inter alia, depend on transport and other costs. Thus, traders devise some legal means allowing them to rely on their trade marks to create trade barriers against entry into the national market of similar goods, bearing identical trade mark, from a different country.

It is commonplace that traders who want to benefit from a trade mark monopoly are incorporated in some forms of legal personality, such as limited liability companies. In the circumstances, whenever a company plans for a business establishment in a location other than the home country will probably establish a manufacturing and/or a distributing subsidiary which will be the trade mark owner in that country. Thus, the doctrine of trade mark origin is rendered redundant and does not come to the rescue of the free movement of goods since the identical trade mark is registered in the name of the subsidiary company in each of the EAC Partner States. This is because a subsidiary's legal personality is distinct from that of the parent company. As a corollary to this, each subsidiary will have a right to claim a right of origin in relation to the goods it manufactures or distributes. This has the legal effect that a subsidiary company may legally object when goods are imported into the territory where it is established. The sound reason for such objection is obvious: The subsidiary did not mark the goods with the indication of origin that they bear and which it owns for its territory.

However, economic perspectives in relation to the discrimination over the trade mark ownership (exemplified in the above scenario) would not justify 
compartmentalisation of the national markets of the EAC Partner States. ${ }^{143}$ Two arguments supporting this conclusion loom high: (a) the goods emanate from a single commercial group or linkage, and (b) the trade marks are just used to inform consumers the differences in the legal personalities of the companies constituting the group. ${ }^{144}$

\section{bb) Guarantee of quality}

The last paragraph of section C (I)(1)(b) of this chapter clarifies that, if consumers are interested in origin of the goods or services it is normally because the origin imports an expectation about some quality of the goods or services concerned. This implies that the trade mark proprietor has a right to prohibit further commercialisation of goods which have been subjected to a poor storage or any condition that result in deterioration of the quality after those goods have left the proprietor's sphere of control. Thus, quality control of branded goods is in the consumer interests, hence overrides the EAC principle of free movement of goods. The prevailing opinion in this connection holds that:

Trade marks enable entrepreneurs to reap the fruits of their commercial efforts, and they thereby encourage further investment in the quality and variety of goods offered. This benefits consumers, who also profit from the massive reduction of search costs entailed by the use of trade marks, an aspect which, from the perspective of information economics, figures as the primary objective and justification for trade mark protection. ${ }^{145}$

It must be accentuated that trade mark rights are essential for the attainment of a system of fair competition in the products' (or services') relevant market. Such a system of competition would be distorted, unless competitors are "able to attract and retain customers by the quality of their goods or services, which is made

143 The US legal position may serve as a role model in this respect: A US trade mark proprietor cannot restrict parallel imports of trade-marked goods, provided that "the mark on the goods is an application of a foreign trade mark and the foreign and the US trade mark owners are the same entity or are in a parent-subsidiary relationship or are subject to common ownership or control" ( $c f$. HAYS, T., "Parallel Importation under the European Union Law" 11 (Sweet \& Maxwell, London 2004).

144 Cf. CORNISH, W.R. \& PHILLIPS, JENNIFER, "The Economic Function of Trade Marks: An analysis with Special Reference to Developing Countries", 13(1) IIC 41, 45 (1982).

145 Cf. KUR, A., "Strategic Branding: Does Trade Mark Law Provide for Sufficient Self Help and Self Healing Forces?" in: GOVAERE, I. \& ULLRICH, H. (eds.), "Intellectual Property, Market Power and the Public Interest" 192 (P.I.E. Peter Lang, Brussels; New York 2008). 
possible only by distinctive signs allowing them to be identified". ${ }^{146}$ Thus, the trade mark's function of guaranteeing a quality is best realised through strong distribution systems based on the trade mark proprietor's ability to oppose marketing, by parallel traders, of lesser quality goods or the marketing of identical trade-marked products sold through unauthorised distribution systems and which do not enjoy "after-sales services". ${ }^{147}$

\section{The Principle of trade mark exhaustion}

The principium of trade mark exhaustion is one of the legal mechanisms employed to ensure that trade mark rights are only used in consonance with the functions intended of them. One of the legal pronouncements of the $20^{\text {th }}$ century regards exhaustion of trade-mark rights as:

[A] figurative expression of the principle that it is incompatible with the limited purpose of the trademark monopoly for a trademark owner to impede on grounds of trade mark law the marketing of goods which have initially been marked and placed on the market with the trademark owner's consent. ${ }^{148}$

This liberal pronouncement, which was rendered in the course of the court's interpretation of the German Trade Mark Act, has since been reduced to a limited form commensurate with Germany's obligations under the European law. ${ }^{149}$

a) Forms of trade mark exhaustion

The principle of trade mark exhaustion confines a proprietor's trade mark monopoly right within a certain geographical area. ${ }^{150}$ The specific scale of this

146 ECJ, Case C-2006/01, Arsenal Football Club plc v Matthew Reed [2002] ECR I-10273, para. 47.

147 HAYS, T., "Parallel Importation under the European Union Law" 9 (Sweet \& Maxwell, London 2004).

148 Bundesgerichtshof (German Federal Supreme Court) 02.02.1973 Case: I ZR 85/71 CINZANO, 4(3/4) IIC 432 (1973).

149 Before its amendment to comply with Article 7 of the TD (which is similar to Article 13 of the CTMR) which requires Member States to observe the principle of regional exhaustion ( $c f$. section C (I)(2)(d) of this chapter), the German Trade Mark Act enforced the principle of international exhaustion.

150 This is in line with the position that since the "function of the trade mark is to be assessed in reference to a particular territory" (ECJ, Case C-9/93, IHT Internationale 
area has to be stipulated in the law governing the trade mark rights concerned. The conditions for trade mark registration and the extent of exclusive rights stemming thereof are also determined by the same law which sets out the geographical scale relevant for exhaustion of trade-mark rights. ${ }^{151}$

The territorial linking of the principle of exhaustion may take one of the three forms, namely, national, international and regional trade mark exhaustion.

\section{b) National exhaustion}

Trade mark law of a particular country is said to enforce the principle of national exhaustion if it does not grant the proprietor of trade mark rights some powers to restrict others from further commercialising goods bearing the proprietor's trade mark, where the proprietor or any other person permitted by him had initially placed those goods on the national market in the country where the trademark rights are protected. ${ }^{152}$ The principle of national exhaustion is essentially recognition of the reality that intellectual property laws of country A exist independently of intellectual property laws of country B or country C. It is natural that intellectual property laws of country A should have no legal effects on the extinction of intellectual property rights created in accordance with the laws of country B or country C and vice versa. Thus, any event taking place in country B or country $\mathrm{C}$ in relation to goods bearing a trade mark registered in country $\mathrm{A}$ should have no legal impact on the rights protected in country A. The proprietor of a trade mark in country $\mathrm{A}$ is thus empowered by the principle of national trade mark exhaustion to prohibit marketing in country A of the goods he has consensually put on the market of country B or country C. ${ }^{153}$

The economic justifications of the principle of national exhaustion are associated with the need to reserve the national market for the proprietor against parallel importers of the goods marketed outside the national territory of a country in which the proprietor's trade mark is protected. As with any other form

Heiztechnik GmbH v Ideal-Standard GmbH [1994] ECR, I-02789, para. 48), so should the principle of exhaustion of trade mark rights.

$151 C f$. MÜHLENDAHL, A. \& STAUDER, D., "Territorial Intellectual Property Rights in a Global Economy - Transit and other "Free Zones", in: PRINZ ZU WALDECK UND PYRMONT, W., et al. (eds.), "Patent and Technological Progress in a Globalized World, Liber Amicorum for Joseph Straus" 653et seq. (Springer, Berlin 2009).

152 Cf. SLOTBOOM, M. M., "The Exhaustion of Intellectual Property Rights - Different Approaches in EC and WTO Law", 6 JWIP 421 (2003).

153 Cf. HAYS, T., "Parallel Importation under the European Union Law" 8 (Sweet \& Maxwell, London 2004). 
of exhaustion, national trade mark exhaustion safeguards the interests of a trade mark holder by limiting the rights of third parties to use the trade mark. In this sense, the national exhaustion principle guarantees a reward to a trade mark proprietor for his investment by extending to him a right to be the first to place the goods bearing the trade mark on the national market. ${ }^{154}$

This is in line with the hypothesis advanced in section B (II) of this chapter that, relying on the principle of national trade mark exhaustion and the right to have multiple trade mark registrations in various countries, trade mark proprietors are able to foreclose the ability of third parties to engage on further commercialisation of trade-marked goods after the first marketing by the proprietor of the said goods in any part of the EAC territory. Indeed, a proprietor's goods bearing a trade mark registered in Tanzania cannot be lawfully marketed in Tanzania if the first sale takes place in Kenya or in Uganda. Thus, national exhaustion principle is likely to affect trade between the EAC Partner States. ${ }^{155}$ Such rule of exhaustion does not encourage parallel importation of branded goods, and thus making it difficult for the consuming public to have access to cheaper products due to higher prices resulting from the absence of competition through parallel trade and inter-brand competition. ${ }^{156}$

\section{c) International exhaustion}

When international exhaustion is applicable to a certain trade mark, the geographical confinement of the rights concerned does not matter. All that a trade mark proprietor is required to do in order to exhaust his trade mark rights is just to place the goods bearing his trade mark on any part of the world. ${ }^{157}$ It does not make any difference if this part of the world is the market in a developing, least or fully developed country. It follows that, unless the condition of the goods

$154 C f$. "The Economic Consequences of the Choice of Regime of Exhaustion in the area of Trade Marks: Final Report for DG XV of the European Commission" - A study report prepared (in 1999) by the National Economic Research Associates (NERA), SJ Berwin, and IFF Research (henceforth, the NERA report)), p. i.

155 As a matter of principle, the Protocol on the Establishment of the EAC Common Market aims to remove trade barriers between Partner States. However, this aim may not be realised due to the absence of the nexus necessary to achieve this end insofar as the relationship between trade marks and the free movement of goods is concerned (cf.section B (II) of this chapter).

156 Commission of the European Communities, "Exhaustion of Trade Mark Rights" - A Working Document from the Commission Services of 21 June 1999, at p.3.

157 Cf. TORREMANS, P., "Intellectual Property Law" (5th ed.) 448 (Oxford University Press, Oxford 2008). 
is altered, the principle of international exhaustion has the consequences that a proprietor of a national trade mark cannot prohibit the importation into the domestic market of the goods he has marked abroad and placed them on the market there. ${ }^{158}$

While international exhaustion of trade mark rights is a tool that diminishes the ability of trade mark proprietors to dissect the global market into national markets, it also serves as a legal mechanism that destabilises price differences across regions or countries ${ }^{159}$. This is achieved through arbitrage. Where a trade mark proprietor adopts differential pricing as a marketing tool, arbitragers learn closely the trade mark proprietor's business scheme to identify the markets where branded goods are sold at the lowest price and the highest price. After mastering the business scheme, arbitragers buy the lowest price products and compete with the trade mark proprietor's goods in the highest price market.

The principle of international exhaustion may thus be criticised mainly because "it is not able to take account of differences in intellectual property regimes, nor of the policy decisions that favour isolated markets". ${ }^{160}$ Moreover, only those firms with the capability to respond to the global market according to differing national tests may benefit from the rule of international exhaustion. Opponents of this rule argue that insofar as the world market is not unified in a single commercial, economic and regulatory framework international exhaustion should be avoided. ${ }^{161}$ By the same token, if the low-quality goods are parallel imported to compete with the higher-quality goods, consumers would be confused since both products bear identical trade marks. To avoid consumer confusion the trade mark proprietor would be inclined to set up some control mechanism, which may turn out to be costly, and thus outweigh the whole concept of differential pricing. On the other hand, "parallel imports conducted by different agents and through different ports, are likely to confuse customs officials and make it more difficult to identify counterfeits, thus increasing the flow of the latter". ${ }^{162}$

A common argument for maintaining differential pricing (which works successful under legal conditions of national or regional exhaustion ${ }^{163}$ ) is that

Cf. The judgment of the German Federal Supreme Court in Maja case, 66(7) GRUR 372 (1964).

159 More on differential pricing, see SZYMANSKI, S., "International Exhaustion: A Review of Economic Issues" (Intellectual Property Institute, London 1999).

160 HAYS, T., "Parallel Importation under the European Union Law" 7 (Sweet \& Maxwell, London 2004).

$161 C f$. The NERA report, p. 52.

$162 C f$. The NERA report, p. 53.

163 Regional exhaustion is covered in section C (I)(2)(d) of this chapter. 
countries have different levels of tax rates, environmental standards, and advertising costs, just to mention but a few. ${ }^{164} \mathrm{~A}$ trade mark proprietor has to take into account all these factors and accordingly determine which price in a given market will minimally or sufficiently reward him.

It is questionable whether adoption of international trade mark exhaustion in the EAC would be an economically justifiable policy decision. If one considers the level of economic development of the individual EAC Partner States (all of whom, except Kenya, are categorised by the United Nations Organisation as least developed countries (LDCs) $)^{165}$ and their combined GDP and average GDP per capita, ${ }^{166}$ it would be apparent that the rule of international trade mark exhaustion would not have any positive impact on the EAC.

Admittedly, the principle of international exhaustion is in the general interests of free trade and competition and thus in the interests of consumers. ${ }^{167}$ The question lies however with the preparedness and the ability of the EAC Partner States to take advantages of this free trade scheme. With their unstable and undeveloped economies, EAC States are not able to attract any meaningful parallel imports of trade-marked goods from developed economies. ${ }^{168}$ This would be one of the grounds for excluding international exhaustion in the EAC, and instead devise a form of trade mark exhaustion that would be instrumental in enabling EAC firms becoming more competitive. Moreover, the appropriate form of trade mark exhaustion should comply with the fundamental principles underlying the functioning of EAC Common Market.

\section{d) Regional Exhaustion}

At the present time, the principle of regional exhaustion of trade mark rights is only observed in the European Union. Pursuant to this principle, the placing of

$164 C f$. The NERA report, p. 52.

165 The list of LDCs is available at $<$ http://www.unohrlls.org/en/lde/related/62/> (Status: 30 July 2012).

166 EAC Partner States have a combined GDP (Market Prices) of $\$ 79.2$ billion and average GDP per capita of $\$ 685$ (Source: EAC Facts \& Figures Report (2011)) (information available also at $<$ http://eac.int $>$ (Status: 30 July 2012).

167 EFTA Court 03.12.1997 E-2/97 “Mag Instrument", 29(3) IIC 316 (1998), para 19.

168 This conclusion derives from the fact that the practice of parallel importation is dependent on differential pricing, whereby goods placed on the low-price market are exported to compete with the goods a trade mark proprietor places on the higher-price market. Thus, moving from the premises that the purchasing power of EAC citizens is very low, it is economically illogical to envisage a scenario in which goods put on the higher-price market could be parallel traded in the EAC at a large scale. 
trade-marked goods on any part of the respective regional bloc exhausts the trade mark rights irrespective of whether the trade mark concerned is a nationally, regionally or internationally registered trade mark. Legal, economic and practical justifications of this principle are discussed in chapter 6 infra.

\section{Trade Mark Exhaustion in the EAC}

a) The general rule

aa) The Tanzanian law

The exclusive rights which a proprietor of a trade mark registered in Tanzania enjoys do not extend to:

goods which have been sold or offered for sale in Tanzania under the trade mark by the proprietor or any associated company of the proprietor, wherever incorporated or with the proprietor's consent, unless the condition of the goods is modified or impaired after they have been sold or offered for sale. ${ }^{169}$

Two legal concepts may be extracted from the above quotation, namely, (1) "goods which have been sold", and (2) "goods which have been offered for sale". Concept (1) is a practical translation of the legal position that a trade mark only extends to its proprietor a limited monopoly in relation to the goods or services and therefore corresponds with the classical principle of trade mark exhaustion. On the other hand, it is doubtful whether concept (2) is designed to preserve interests of the trade mark proprietor. The court in Tanzania has not yet had an opportunity to expound the meaning of the term "goods which have been offered for sale". Nonetheless, the term cannot be taken to refer to a scenario in which a trade mark proprietor may have already parted with possession of his trade-marked goods by way of sale. Thus, the inclusion of the term in Section 32(3) (c), of the Trade and Service Marks Act, ${ }^{170}$ as a condition for trade mark exhaustion, takes away the right to enjoy specific subject matter of a trade mark by the proprietor. ${ }^{171}$ Put into the context of the tenet of national exhaustion, the principle of specific subject matter of a trade mark connotes a trade mark proprietor's right to be the first to market his trade-marked goods in Tanzania. ${ }^{172}$

169 Sec 32(3) (c), Trade and Service Marks Act No 12/86.

170 Act No. 12/86 of the Laws of Tanzania.

171 The concept "specific subject matter" and the phrase "goods which have been offered for sale" are discussed in Chapter 6 infra.

172 The principle has been employed, in the EU's context, to mean that when a trade between Member States may be affected by a proprietor who relies on his right, such 
The proprietor might not be able to enjoy the specific subject matter of his trade mark should his intellectual property rights be declared exhausted on the sole ground that he has directly or constructively ${ }^{173}$ offered the trade-marked goods for sale without actually selling them. This can be explained in the following manner: Assume that company X offers its trade-marked spare parts for sale in Tanzania. While the spare parts are still packed in the stores, $\mathrm{X}$ discovers some defects in the spare parts and decides to recall them. After rectifying the defects, $\mathrm{X}$ changes the marketing strategy and decides to market the recalled spare parts in markets other than Tanzania. Assume further that company Y buys the spare parts sold by $\mathrm{X}$ in Ghana intending to parallel import the same into Tanzania. Even if company $\mathrm{X}$ has not yet enjoyed the specific subject matter in relation to those spare parts insofar as the Tanzania market is concerned, $\mathrm{X}$ cannot enjoin $\mathrm{Y}$ from putting the spare parts on the Tanzanian market: The first act of offering for sale done prior to the recall of the spare parts had exhausted X's respective trade mark rights.

bb) The Kenyan and Ugandan laws

While the position excluding trade mark proprietor from controlling goods already sold is expressly stated under the Tanzanian law, it is only by necessary implication one would conclude that such position is stipulated under the Kenyan and Ugandan laws. According to the pertinent provisions, ${ }^{174}$ a proprietor cannot control tradability of the after-market goods, unless he is allowed by a contract concluded before the initial marketing of the goods concerned. The contract binds buyers only in relation to some matters, which if undertaken would be detrimental to the proprietor's investment. ${ }^{175}$ This contractual weaponry should

reliance must be justified on the grounds of protecting the specific subject-matter of the right concerned. The principle, therefore, aims to prevent trade-mark rights to be used to "partition off national markets and thereby restrict trade between the Member States, in a situation where no such restriction was necessary to guarantee the essence of the exclusive right flowing from the trade mark ( $c f$. ECJ, Case C-16/74 Centrafarm BV et Adriaan de Peijper $v$ Winthrop BV [1974] ECR 01183, para. 11).

173 Constructive offer of the goods refers to a scenario whereby the trademark proprietor does not directly offer the trade-marked goods for sale but authorises another person to do so.

174 S. 9(1), K. \& Secs $36 \& 40$, U.

175 Acts which a trade mark proprietor may prohibit by contract are described under S.9(2), K. \& S. 36, U.: They include application of a trade mark to proprietor's goods after the buyer has altered their condition or the original labelling on the goods. 
be regarded as an exception to the general rule regarding exhaustion after the goods had been sold. ${ }^{176}$

b) Exception to the general rule

aa) The Tanzanian law

An explicit stipulation in the Tanzanian trade mark law rules out exhaustion of trade mark rights in respect of goods whose condition is modified or impaired after those goods had been sold. ${ }^{177}$ This exception can be collaborated by the provisions of Section 32(2), T. The provisions regard a proprietor's trade mark rights as not exhausted, particularly, when: (1) a trade mark is applied to the goods after alteration of the state or condition, get-up or packaging of these goods; (2) a trade mark which the proprietor applied to the goods is altered or obliterated; (3) Other matter are added to the goods, bearing a trade mark, in such a way as to suggest that the matter was so added by the proprietor of the trade mark or with his consent; (4) another trade mark is added to the branded goods; and (5) some description labels are added to the goods in a way that injures the acquired reputation of the trade mark concerned.

bb) The Kenyan and Ugandan laws

As opposed to the Tanzanian position, the Kenyan and Ugandan laws incorporate a limited exception to the general principle of trade mark exhaustion. The factors mentioned in (aa) above whose proof justifies a trade mark proprietor to control the goods he had initially sold, are also enshrined in the Kenyan and Ugandan laws. ${ }^{178}$ Whereas by virtue of the Tanzanian law these factors apply automatically, the Kenyan and Ugandan laws require a proprietor to conclude a contract (prior to selling the goods) with the buyers, so that when the buyers breach the conditions stipulated in the contract, exhaustion of trade mark right will be regarded not to have taken place. Thus, in absence of contractual relationship, the principle of exhaustion may prohibit the proprietor of a trade

176 A position suggesting that Kenya and Uganda observe the principle of international trade mark exhaustion is outlined in section C (I) (4) (b) of this chapter.

177 S. 32(3) (c), T.

178 S. $9(2)$, K. \& S. 36 , U. 
mark registered in Kenya and Uganda from intervening in further commercialisation of the goods whose condition has been altered after the initial marketing.

\section{c) Conclusion thereof}

Basically, the above exception may be seen as a conduit pipe through which the quality function of a trade mark is guaranteed. The Tanzanian trade mark legislation caters fully to this guarantee. ${ }^{179}$ This is opposed to the Kenyan and Ugandan laws, which makes the quality control issue dependent on a contract. Insofar as a trade mark proprietor is presumed to have no power to block sales of goods whose condition has been altered, in absence of a contract to that effect, the Kenyan and Ugandan trade mark laws do not attach a sufficient weight to the quality function of a trade mark.

\section{Place of sale for the purpose of exhaustion}

a) The Tanzanian law

In order for trade mark rights to be exhausted within the ambit of Section 32(3) (c), T., a sale of goods (bearing a trade mark protected in Tanzania) must take place on the Tanzanian territory. Thus, the immediately preceding provision enforces the principle of national exhaustion of trade mark rights.

b) The Kenyan and Ugandan laws

The Kenyan and Ugandan laws do not expressly stipulate a place where the sale of branded goods should be undertaken for the proprietor to exhaust his trade mark rights. In this regard, these laws are imprecise: They do not convey an immediate understanding as to the form of exhaustion relevant for trade mark

179 The Tanzanian law takes the issue of quality control further to the realm of assignment of trade marks. Accordingly: "A licence contract shall be invalid in the absence of relations or stipulations between the registered proprietor of the trade or service mark and the proposed registered user, ensuring effective control by the registered proprietor of the quality of the goods or services of the proposed registered user in relation to which the trade or service mark is to be used" (S. 44(1), T.). 
rights protected in Kenya or in Uganda. This begs a question whether such impreciseness may be justified under the provisions of the TRIPs agreement.

The TRIPs agreement is commendable for being the most successful legal instrument that sets minimum intellectual property norms with which contracting parties have to comply. ${ }^{180}$ However, the agreement does not endeavour the same spirit with respect to the principle of trade mark exhaustion. Article 6 TRIPs gives a lee way to each contracting state to decide on the form of trade mark exhaustion. The Article does not oblige contracting parties to stipulate the principle of trade mark exhaustion in their trade mark laws nor does it require them to specify a form of exhaustion that is to be observed.

On the other hand, where a particular law (such as the Kenyan or Ugandan trade mark law) does not literary and expressly mention the principle of trade mark exhaustion, an inference can be drawn from Article 16 TRIPs that such a law enforces the principle of international exhaustion. This surmise may be deduced from the regime of parallel importation, which flourishes only if the extent to which trade mark rights are protected is clearly demarcated. Article 16 entitles a trade mark proprietor to exclude third parties from using in trade a sign similar or identical to the proprietor's trade mark only if the use of the sign in relation to goods or services which are similar with or identical to those of the trade mark proprietor causes consumer confusion. ${ }^{181}$ Thus, "to the extent that products are identical and of equal quality, the concept of trademark protection in the TRIPs Agreement does not allow the ban of parallel imports". ${ }^{182}$

A note of caution insofar as the foregoing conclusion is concerned looms high: Article 16, including other provisions in the TRIPs agreement, does not prohibit contracting parties to extend to trade mark proprietors protection beyond the TRIPS' minimum rights. ${ }^{183}$ Thus, the above interpretation of Article 16 is not mandatory; countries may still qualify it by incorporating in their national laws the principle of national exhaustion or that of regional exhaustion. The absence of express stipulation of the principle of exhaustion in the Kenyan and Ugandan laws must thus be interpreted to mean that the legislative authorities in Kenya and in Uganda have decided to comply with the minimum provisions of Article

180 Cf. SOUTH CENTRE, "The TRIPs Agreement - A Guide for the South: The Uruguay Round Agreement on Trade-Related Intellectual Property Rights" xi (South Centre, Geneva 2000).

181 See the standards of proof of the likelihood of confusion in section E (II) of chapter 4 below.

182 COTTIER, T., "Trade and Intellectual Property Protection: Collected Essays" 160 (Cameron May Ltd, London 2005). 
16 TRIPs. Hence the principle of international trade mark exhaustion applies to trade mark rights protected in these countries. ${ }^{184}$

\section{Relevant principles of international law}

Kenya and Uganda implement the principle of international exhaustion, whereas Tanzania observes the doctrine of national trade mark exhaustion. ${ }^{185}$ The stipulation of the principle of national exhaustion in the Tanzanian trade mark law does not support the regime of the free movement of branded goods in the EAC Common Market. ${ }^{186}$ Does it mean that the rule in the Tanzanian law contravenes the provisions of TRIPs Agreement or of GATT?

\section{TRIPs Agreement}

a) Legislative freedom under Article 8 TRIPS

Article 8(1) of TRIPS allows contracting parties to formulate or amend their laws and regulations in order to "promote the public interests in sectors of vital importance to their socio-economic and technological development" provided that the laws or regulations are consistent with the provisions of the TRIPs agreement. By virtue of its Article 6, TRIPs leaves the regulation of the principle of trade mark exhaustion to the Member States. ${ }^{187}$ Tanzania has therefore taken advantage of this freedom to put in place a national exhaustion principle. This law thus complies with the TRIPs agreement notwithstanding the adverse effects it has on the movement of branded goods in the EAC Common Market.

b) The chapeau

The restrictions that trade mark proprietors in Tanzania are able to impose on the free movement of trade-marked goods in the EAC common market may be adjudged as being contrary to the overall spirit of the TRIPS Agreement whose

184 Cf. COTTIER, T., "Trade and Intellectual Property Protection: Collected Essays" 160 (Cameron May Ltd, London 2005).

185 See section C (I)(4) of this chapter.

$186 C f$. section C (I)(2)(b) of this chapter.

187 Article 6 of TRIPS is further analysed in section C (II)(1)(d) of this chapter. 
preamble's chapeau demonstrates the contracting parties' desire to reduce "distortions and impediments to international trade". The chapeau closes with an ostensibly strong message to legislative authorities of the contracting parties: measures and procedures to enforce trade mark rights should not "themselves become barriers to legitimate trade". Since intellectual property rights are not considered as barriers to legitimate trade within the ambit of the last part of the preamble's chapeau, but the measures and procedures to enforce them, ${ }^{188}$ it is hardly possible to find a contravention of the chapeau by the national legislature which enacts a law empowering trade mark proprietors to exclude trade-marked goods from the local market pursuant to the principle of national exhaustion.

\section{c) The national trade mark exhaustion meets TRIPS' minimum standards}

The spirit underlying the TRIPS agreement is to enshrine minimum provisions, with which the Member States have to comply. ${ }^{189}$ In view of the discussion on the provisions of Article 16(1) TRIPS, ${ }^{190}$ the principle of international trade mark exhaustion constitutes minimum standards within the ambit of the trade mark regime endorsed in the agreement. ${ }^{191}$ The fact that the principle of national trade mark exhaustion stipulated in the Tanzanian Trade and Service Marks Act may be invoked to frustrate free movement of trade-marked goods does not mean that this legislation abrogates the TRIPS obligations. While for instance, the absence of express stipulation of the principle of exhaustion in the Kenyan and Ugandan laws must be interpreted to mean that the legislative authorities in Kenya and in Uganda have decided to comply with the minimum provisions of Article 16 TRIPs ${ }^{192}$ incorporation of a national trade mark exhaustion in a trade mark instrument should be regarded to be within a legislative freedom extended to the Member States by virtue of Article 1(1) TRIPS. ${ }^{193}$

188 Cf. CORREA, C. M., "Trade Related Aspects of Intellectual Property Rights: A Commentary on the TRIPS Agreement" 3 (Oxford University Press, Oxford 2007).

189 Cf. SOUTH CENTRE, "The TRIPs Agreement - A Guide for the South: The Uruguay Round Agreement on Trade-Related Intellectual Property Rights" xi (South Centre, Geneva, 2000).

$190 C f$. Section C (I)(4)(b) of this chapter.

191 The key trade mark provisions of the TRIPS agreement are contained in Articles 15 to 21.

192 Cf. COTTIER, T., "Trade and Intellectual Property Protection: Collected Essays" 160 (Cameron May Ltd, London 2005).

193 Article 1(1) of TRIPS provides, in part, that "Members shall give effect to the provisions of this Agreement. Members may, but shall not be obliged to, implement in their law 


\section{d) The debate on Article 6 TRIPS}

The principle of national exhaustion may further be justified in light of the provisions of Article 6 TRIPS. The Article has wittingly excluded the possibility of the doctrine of exhaustion being invoked in relation to a cause of action the settlement of which is pursued within the framework of TRIPS, ${ }^{194}$ save where the issue of exhaustion is raised in relation to the principle of national treatment and the most favoured nation respectively contained in Articles 3 and 4 TRIPS. ${ }^{195}$ Commentators have offered a purposive construction of Article 6 TRIPS to the effect that the gist of the Article was to provide the contracting states with unhampered freedom to determine a form of trade mark exhaustion to be incorporated in the national trademark legislation. ${ }^{196}$ However, once a contracting party had opted for any form of exhaustion, is then obliged to offer the same standards to all persons without any discrimination. In this sense, reliance on the principle of exhaustion to frustrate the free movement of goods could not be justified under TRIPS if it contravened the national treatment ${ }^{197}$ and the most favoured nation ${ }^{198}$ principles contained in the Agreement. However, as these principles are applied in TRIPS based on the nationality of persons and not the origin of goods ${ }^{199}$ it is very difficult to envisage a scenario in which a parallel importer may avoid hurdles to the Tanzania's market access caused by the principle of national exhaustion.

On the other hand, it has been observed that the hiatus, in relation to a specific principle of trade mark exhaustion, left in Article 6 of TRIPS, especially the

more extensive protection than is required by this Agreement, provided that such protection does not contravene the provisions of this Agreement."

194 Articles 63 and 64 of TRIPS deal with conflicts avoidance and settlement of disputes related to TRIPS.

195 BRONCKERS, M.C.E.J., "The Exhaustion of Patent Rights under WTO Law", 32(5) JWT 137, 152 (1998).

196 Cf. C. M. CORREA, "Trade Related Aspects of Intellectual Property Rights: A Commentary on the TRIPS Agreement" 78 (Oxford University Press, Oxford 2007).

197 Pursuant to the TRIPS' national treatment principle "Each Member shall accord to the nationals of other Members treatment no less favourable than that it accords to its own nationals with regards to protection of intellectual property..." (cf. Article 3(1) of TRIPS).

198 The most favoured nation principle as incorporated in Article 4 of TRIPS has the effect that: "With regard to the protection of intellectual property, any advantage, favour, privilege or immunity granted by a Member to the nationals of any other country shall be accorded immediately and unconditionally to the nationals of all other Members".

199 Cf. HEATH, C., "The Most-Favoured Nation Treatment and Intellectual Property Rights", in: HEATH, C. and SANDERS, K. (eds.), "Intellectual Property and Free Trade Agreements" 139 (Hart Publishing, Oxford and Portland 2007). 
unambiguous exclusion of the application of the principle insofar as settlement of disputes in the context of TRIPS is concerned, does not exclude issues concerning trade mark exhaustion from being addressed in the context of GATT provisions. ${ }^{200}$ While it has been reiterated that TRIPS and GATT may be applied cumulatively, ${ }^{201}$ provisions of the former are regarded as a permissive regime of intellectual property rights subject to the prescriptive regime contained in the provisions of the latter. ${ }^{202}$ Thus, "the basic GATT principles are made applicable to the TRIPS Agreement and any conflict between the Members' obligations under TRIPS with any other covered Agreement will be governed by the GATT rules". 203

\section{The GATT 1994}

The general objective of GATT is to establish a multilateral trading regime among the contracting parties in order to realise trade liberalisation. ${ }^{204}$ In this connection, GATT lays down some standards that the contracting parties are obliged to observe. ${ }^{205}$ Insofar as the free movement of goods is concerned, the most pertinent standards include the national treatment, the most favoured nation principle and prohibition of quantitative restrictions on trade. Since it negatively affects the free movement of goods in the EAC common market, the principle of national exhaustion of trade mark rights observed in Tanzania can hardly be justified unless it complies with the GATT standards. The analysis in this regard follows below.

200 Cf. CARVALHO, N.P. de, "The TRIPS Regime of Trademarks and Designs" 144 (Kluwer Law International, The Hague 2006).

201 Cf. HEATH, C., "The Most-Favoured Nation Treatment and Intellectual Property Rights", in: HEATH, C., and K. SANDERS (eds.), "Intellectual Property and Free Trade Agreements" 142 (Hart Publishing, Oxford and Portland 2007).

202 VERMA, S.K., "Exhaustion of Intellectual Property Rights and Free Trade - Article 6 of the TRIPS Agreement" 29(5) IIC 534, 553 (1998).

203 VERMA, S.K., "Exhaustion of Intellectual Property Rights and Free Trade - Article 6 of the TRIPS Agreement" 29(5) IIC 534, 553 (1998).

204 DHANJEE, R. \& CHAZOURNES, L. B. de "Trade Related Aspects of Intellectual Property Rights (TRIPS): Objectives, Approaches and Basic Principles of the GATT and of Intellectual Property Conventions", 24(5) JWT 6 (1990).

205 All individual EAC Partner States are contracting parties to the Agreement establishing the WTO in which the GATT forms part (cf. KIEFF, F. S. \& NACK, R., "international, United States and European Intellectual Property: Selected Source Material 2007-2008" 31-34 (Aspen Publishers, New York 2006). 
a) The national treatment

Article III GATT expounds the principle of national treatment. Part III.4 of the Article stipulates that:

The products of the territory of any contracting party imported into the territory of any other contracting party shall be accorded treatment no less favourable than that accorded to like products of national origin in respect of all laws, regulations and requirements affecting their internal sale, offering for sale, purchase, transportation, distribution or use. The provisions of this paragraph shall not prevent the application of differential internal transportation charges which are based exclusively on the economic operation of the means of transport and not on the nationality of the product.

A violation of the above Article "presupposes, among other things, that the imported trade-marked products are "like" domestic products and accorded "less favourable" treatment". ${ }^{206}$ By empowering a trade mark proprietor to prohibit the marketing of goods (bearing a national trade mark registered and protected in Tanzania) initially marketed in EAC Partner States other than Tanzania while at the same time allowing him to market other batches of similar goods on the Tanzanian market, the national trade mark exhaustion may be regarded as a contravention of the GATT's national treatment principle. The behaviour which the national treatment principle in GATT proscribes is the discrimination between imported and national goods. To the extent that the trade mark proprietor seeks to exclude from the local market imported goods in favour of the local goods, the behaviour amounts to discrimination and thus may be regarded to contravene the provisions of Article III GATT. ${ }^{207}$

b) The most favoured nation principle

The most favoured nation principle is reflected in Article I (1) of the GATT 1947 as follows:

With respect to customs duties and charges of any kind imposed on or in connection with importation or exportation or imposed on the international transfer of payments for imports or exports, and with respect to the method of levying such duties and charges, and with respect to all rules and formalities in connection with importation and exportation,

206 EHRING, L., "De facto Discrimination in WTO law: National and Most-Favoured-

Nation Treatment - or Equal Treatment?", Jean Monnet Working Paper 12/01 of 2001, available at $<$ http://centers.law.nyu.edu/jeanmonnet/papers/> (Status: 30 July 2012). See also TREBILCOCK, M. J. \& HOWSE, R., "Regulation of International Trade" 100 (Routledge, London and New York 2005).

207 Cf. VERMA, S.K., "Exhaustion of Intellectual Property Rights and Free Trade - Article 6 of the TRIPS Agreement" 29(5) IIC 534, 553 (1998). 
and with respect to all matters referred to in paragraphs 2 and 4 of Article III, any advantage, favour, privilege or immunity granted by any contracting party to any product originating in or destined for any other country shall be accorded immediately and unconditionally to the like product originating in or destined for the territories of all other contracting parties.

In essence, GATT's most favoured nation principle aims to eliminate discrimination between foreign goods brought to a local market in the third country. The principle guarantees that "like products originating in, or destined for, different countries" will enjoy equivalent conditions of competition. ${ }^{208}$ In practice, it is very difficult to spot a situation in which a trade mark proprietor may invoke the principle of national exhaustion in a way opposed to the most favoured nation principle. ${ }^{209}$ A scenario under which application of the principle is possible may be illustrated in the following manner: Suppose that a word trade mark, say PUNCHO, is registered in Tanzania and in Kenya for confectionery products and owned by different proprietors. Assume further that another word trade mark, say, COCOMEAL, is owned by a single proprietor and registered in Uganda also for confectionery products.

In the circumstances, the owner of the PUNCHO trade mark in Tanzania may invoke the principle of national exhaustion of trade mark rights to prohibit the proprietor of PUNCHO trade mark registered in Kenya from importing into Tanzania confections bearing the mark (i.e. PUNCHO). However, although the PUNCHO mark is registered for confectionery products, the proprietor of this mark in Tanzania has no right to prohibit importation into Tanzania of similar products with a different trade mark (say COCOMEAL) other than PUNCHO.

In this way, the principle of national exhaustion allows the trade mark proprietor to discriminate between like, foreign goods (i.e. products from Uganda bearing COCOMEAL trade mark and goods from Kenya with PUNCHO trade mark) and hence a contravention of the most favoured nation principle. Pursuant to the most favoured nation principle, any advantage, favour, privilege or immunity granted to goods (bearing COCOMEAL trade mark) imported into Tanzania from Uganda must immediately and unconditionally be extended to

208 Cf. BOSSCHE, P. van den, "The Law and Policy of the World Trade Organization: Text, Cases and Materials" (2nd ed.) 324 (Cambridge University Press, Cambridge 2008).

209 "... cases where the MFN principle could be invoked are mostly those that do not relate to intellectual property rights" ( $c f$. HEATH, C., "The Most-Favoured Nation Treatment and Intellectual Property Rights", in: HEATH, C. and SANDERS, K. (eds.), "Intellectual Property and Free Trade Agreements" 142 (Hart Publishing, Oxford and Portland 2007). 
like foreign products (bearing the trade mark PUNCHO) imported to Tanzania from Kenya.

Although from its general legal context the principle of national exhaustion of trade mark rights may not be invoked in a way that contravenes the most favoured nation principle, ${ }^{210}$ the above illustration depicts some special circumstances in which the principle of national exhaustion may be used to discriminate between like foreign products brought to a local market in the third country. It thus suffices to mention that a measure, including one pursued on the pretext of national exhaustion, may contravene the most favoured nation principle as a matter of law or as a matter of fact or both. To put it simply:

A measure may be said to discriminate in law (or de jure) in a case in which it is clear from reading the text of the law, regulation or policy that it discriminates. If the measure does not appear on the face of the law, regulation or policy to discriminate, it may still be determined to discriminate de facto if, on reviewing all facts relating to the application of the measure, it becomes clear that it discriminates in practice or in fact. ${ }^{211}$

The conflict between the most favoured nation principle and intellectual property rights (such as a trade mark) may be resolved under the general exception clause enshrined in Article XX (d) of GATT outlined below. ${ }^{212}$

\section{c) Prohibition of quantitative restrictions under Article XI GATT}

Invoking the principle of trade mark exhaustion to prohibit free movement of goods in the EAC common market is contrary to Article XI (1) GATT, which prohibits contracting parties from imposing non-tariff barriers to international trade. The Article stipulates that:

No prohibitions or restrictions other than duties, taxes or other charges, whether made effective through quotas, import and export licenses or other measures, shall be instituted

210 Essentially, the principle of national exhaustion allows a trade mark proprietor to discriminate between trade-marked goods sold abroad and those marketed in the national market making it possible for the proprietor to prohibit marketing in the domestic market of the goods he sold abroad (cf. section C (II)(2)(a) of this chapter). The most relevant principle of exhaustion insofar as the most favoured national principle is concerned is the principle of regional trade mark exhaustion $(c f$. section C (I)(2)(d) of this chapter). Regional exhaustion allows a trade mark proprietor to discriminate between goods he markets in the national markets of the regional bloc's Member States and those he markets outside the regional bloc and hence a contravention of the most favoured nation principle.

211 Cf. Footnote 8, in: BOSSCHE, P. van den, "The Law and Policy of the World Trade Organization: Text, Cases and Materials" (2nd ed.) 324 (Cambridge University Press, Cambridge 2008).

212 Article XX (d) GATT is analysed in section C (II)(2)(d) of this chapter. 
or maintained by any contracting party on the importation of any product in the territory of any other contracting party or on the exportation or sale for export of any product destined for the territory of any contracting party.

The provisions of Article XI (1) GATT imply therefore that the national exhaustion principle applicable in Tanzania, which does not permit importation into Tanzania of the goods bearing a trade mark protected in Tanzania previously marketed in other EAC Partner States, may be regarded "as a measure having an effect equivalent to a quantitative restriction". ${ }^{213}$ However, it must be noted that Article XI (1) GATT is a general clause, which is subject to exceptions under Article XIX GATT. Pursuant to provisions of the latter Article, measures amounting to quantitative restrictions may generally and as of right be resorted to by a contracting party who can demonstrate that the measure is necessary to avoid some serious injury which the imports may cause to an established industry: A measure geared towards protection of the exclusive rights of a trade mark proprietor does not fall in the foregoing exception. ${ }^{214}$ Such measure would fall under GATT's general exception clause analysed below.

\section{d) The general exception clause under Article XX GATT}

In view of the discussion in the above sections, ${ }^{215}$ it goes without saying that the principle of national exhaustion contravenes the national treatment and the most favoured nation rules on one hand, and is non-tariff barrier on the other, if it is invoked to restrict parallel importation. This general rule, must however be analysed in light of the provisions of Article XX(d) GATT, which provides a safety valve through which contracting parties may avoid the WTO obligations, ${ }^{216}$ to observe the above principles. ${ }^{217}$ Article XX (d) provides that:

Subject to the requirement that such measures are not applied in a manner which would constitute ... disguised restriction on international trade, nothing in this Agreement shall be construed to prevent the adoption or enforcement by any contracting party of measures:

$213 C f$. YUSUF, A. A. and HASE, A. M. von, "Intellectual Property Protection and International Trade: Exhaustion of Rights Revisited", 16(1) World Competition 115, 129 (1992).

214 Cf. VERMA, S.K., "Exhaustion of Intellectual Property Rights and Free Trade - Article 6 of the TRIPS Agreement" 29(5) IIC 534, 554 (1998).

$215 C f$. sections C (II)(2)(a) - (c) of this chapter.

216 Cf. RUSE-KHAN, H. G., "A Comparative Analysis of Policy Space in WTO Law", Max Plank Institute for Intellectual Property, Competition \& Tax Law Research Paper Series No. 08-02, p. 15. The paper is available at: $<$ http://ssrn.com/abstract $=1309526>$ (Status: 30 July 2012).

217 i.e. the principles outlined in sections C (II)(2)(a) - (c) of this chapter. 
(d) necessary to secure compliance with laws or regulations which are not inconsistent with the provisions of this Agreement, including..., the protection of patents, trade marks and copyrights, and the prevention of deceptive practices;

The exception in Article XX GATT is "permissive but cautious towards IPR regulatory measures considered susceptible of hampering free trade and competition". ${ }^{218}$ Application of Article XX (d) GATT is subject to two-tiered provisos, ${ }^{219}$ namely, those contained in the preamble to Article XX GATT (henceforth, the chapeau), ${ }^{220}$ and those contained in paragraph (d) of Article XX. In line with the analysis of the provisos as offered below, the provisions of the chapeau are logically taken into account after the provisions of paragraph (d) of Article XX GATT have been analysed notwithstanding the fact that the chapeau's literary position precedes that of paragraph (d). ${ }^{221}$

\section{aa) Provisos under Paragraph (d) of Article XX GATT}

Provisional justification of a measure which is inconsistent with the provisions of the GATT depends on the country introducing the measure concerned being able to prove two elements, namely, that (1) the measure is one designed to secure compliance with the law or regulation which is not inconsistent with some provisions of the GATT; and that (2) the measure is necessary to secure such compliance. $^{222}$

Incorporating in a trade mark law, and enforcing, the principle of national trade mark exhaustion may be considered as a measure which aims to secure compliance with intellectual property laws. Since intellectual property laws are not generally inconsistent with the provisions of the GATT, the necessity of such

218 CORREA, C. M. \& YUSUF, A. A. (eds.), "Intellectual Property and International Trade - The TRIPS Agreement" (2nd ed.) 8 (Kluwer Law International, Alphen aan den Rijn 2008).

219 Cf. BOSSCHE, P. van den, "The Law and Policy of the World Trade Organization: Text, Cases and Materials" (2nd ed.) 629 (Cambridge University Press, Cambridge 2008).

220 "The chapeau can be generally described as a safeguard against (protectionist) abuse of the ability to justify WTO inconsistencies under Art. XX GATT and so to defer from WTO obligations." Cf. RUSE-KHAN, H. G., "A Comparative Analysis of Policy Space in WTO Law", Max Plank Institute for Intellectual Property, Competition \& Tax Law Research Paper Series No. 08-02, p. 17.

$221 C f$. RUSE-KHAN, H. G., "A Comparative Analysis of Policy Space in WTO Law”, Max Plank Institute for Intellectual Property, Competition \& Tax Law Research Paper Series No. 08-02, p. 17.

222 Cf. Appellate Body Report, Korea - Measures Affecting Imports of Fresh, Chilled and Frozen Beef, T/DS161/AB/R, WT/DS169/AB/R, adopted 10 January 2001, DSR 2001:I, 5, para. 157. 
measure in achieving the desired end results is a decisive factor to a finding on whether the measure should be allowed.

The WTO Appellate Body has offered a circumscription of measures regarded "necessary" within the ambit of Article XX (d) GATT in the following manner:

[A] contracting party cannot justify a measure inconsistent with another GATT provision as "necessary" in terms of Article $\mathrm{XX}(\mathrm{d})$ if an alternative measure which it could reasonably be expected to employ and which is not inconsistent with other GATT provisions is available to it. By the same token, in cases where a measure consistent with other GATT provisions is not reasonably available, the contracting party is bound to use, among the measures reasonably available to it, that which entails the least degree of inconsistency with other GATT provisions. ${ }^{223}$

On the other hand, Mark Stucki offers a criterion to be observed when it comes to determining a necessity of a particular form of trade mark exhaustion. He argues that, if a trade mark law which exceeds TRIPS' minimum standards by offering intensified protection of trade marks is invoked to bar the free movement of goods, such particular law "would not be necessary to protect trademarks in the sense of Article XX (d) GATT". 224 Putting it more specifically, he further opines that " one could assume that the minimum standards of the TRIPS-Agreement define the degree of necessity of "tolerated" trade mark protection, and that increased protection (which is... tolerated under TRIPS) would hardly ever pass the "test of necessity". ${ }^{225}$

One may thus rightly submit that, by having the effect of restricting free movement of trade-marked goods in the EAC, the Tanzania's principle of national exhaustion may not pass the necessity test: The principle goes beyond the minimum standards enshrined in Article 16 TRIPS, which defines the scope of trade mark protection. ${ }^{226}$ Thus, the restriction on the free movement of goods pursuant to principle of national exhaustion "could hardly be considered as necessary to secure the protection of trademark rights". ${ }^{227}$ In view of the WTO Appellate Body decision quoted above, ${ }^{228}$ the Tanzania's principle of national exhaustion could be allowed to operate in a way infringing GATT provisions,

Cf. Appellate Body Report, Korea - Measures Affecting Imports of Fresh, Chilled and Frozen Beef, T/DS161/AB/R, WT/DS169/AB/R, adopted 10 January 2001, DSR 2001:I, 5 , para. 165.

224 STUCKI, M., "Trademarks and Free Trade" 51 (Staempfli Verlag AG, Bern 1997).

225 STUCKI, M., "Trademarks and Free Trade" 51 (Staempfli Verlag AG, Bern 1997).

$226 C f$. the discussion on Article 16(1) of TRIPS offered in section C (I)(4)(b) of this chapter.

227 STUCKI, M., “Trademarks and Free Trade” 51 (Staempfli Verlag AG, Bern 1997).

228 Cf. Appellate Body Report, Korea - Measures Affecting Imports of Fresh, Chilled and Frozen Beef, T/DS161/AB/R, WT/DS169/AB/R, adopted 10 January 2001, DSR 2001:I, 5 , para. 165 . 
only if it were the only reasonable measure with a least degree of inconsistence with GATT provisions available: The reality of the matter is that the principle of international trade mark exhaustion, which is pro-GATT provisions, is available.

bb) Provisos under the chapeau

One of the conditions to which application of the chapeau is subjected requires discriminatory measure complained of to be perpetuated between countries where same conditions prevail. By having the effect of harmonising national intellectual property laws, TRIPS Agreement has made protection standards prevailing in each WTO Contracting Parties to be minimally the same. Thus, any form of trade mark exhaustion enshrined in the contracting party's domestic trade mark law, which discriminates between the contracting parties or which disguisedly imposes restrictions on international trade would hardly fall in the exceptions under Article XX (d) GATT, since this would be a measure applied between WTO contracting parties with the same prevailing legal conditions.

In this regard, by the time when all WTO contracting parties will have transposed the TRIPS Agreement's minimum provisions into domestic law, any form of trade mark exhaustion susceptible of discriminating the contracting parties, or which can disguisedly be invoked to restrict trade between the WTO Members will not likely to be exempted under the provisions of paragraph (d) of Article XX GATT. ${ }^{229}$ Insofar as the principle of national trade mark exhaustion applicable in Tanzania may potentially serve as disguise restriction on international trade, it may not be accommodated in the general exceptions under Article XX (d) GATT.

\section{Concluding remarks}

To address the negative effects of the independent national trade mark systems of the EAC Partner States on the Common Market's principle of free movement of goods, one should move from the premises that the national trade mark regime basically aims to foster the national interests of preserving local industries from competition. However, since the EAC Common Market has been established, ${ }^{230}$ individual interests of the EAC Partner States must be subsumed under the EAC interests. Indeed, the EAC Treaty already defines the Community interests

229 STUCKI, M., "Trademarks and Free Trade" 50 (Staempfli Verlag AG, Bern 1997).

230 On the establishment of the EAC Common Market, see section B(I) of this chapter. 
which, as matter of principle, should either override or co-exist with the national interests depending on the effects of the latter on the former. Where reliance on the national interests severely affects the EAC interests ${ }^{231}$ as is the case with the principle of national exhaustion, the Community interests must prevail. Thus, the nexus between the national interests and the Community interests insofar as the common market for branded products is concerned is missing. A trade mark regime necessary for the achievement of this nexus is addressed in Chapter 7 infra.

231 Establishment of the EAC Common Market is an example of these interests ( $c f$. Article 76, EAC Treaty). 


\section{Chapter 4: Overview of the European Community Trade Mark System}

\section{A. Introductory remarks}

The Community Trade Mark Regulation (CTMR) was enacted in $1993^{232}$ to establish the European Community Trade Mark (CTM) system, which became operational on April 1, 1996. The system permits a single registration to be obtained in respect of a trade mark application processed by a single office that makes a single process resulting in a single registration covering the whole territory of Europe. $^{233}$ The CTM can only be obtained by registration. ${ }^{234}$

In this Chapter, some detailed issues relating to the life of a CTM, from the application stage throughout the granting of a registration and thereafter, are discussed. The chapter can, ideally, be divided into two main parts. The first part is devoted to substantive issues, whereas the second is directed to procedural issues. Central for the substantive part are some issues relating to a CTM registration such as the requirements of graphical representation and the condition that a sign must be distinctive in order to avoid being refused registration based on absolute grounds for trademark refusal. The substantive part addresses also some relative grounds for trademark refusal as well as the CTM infringement and the limitations posed against the CTM rights. The same part outlines some duties in relation to CTM and defines some key terms which are useful for the determination of precedence of trademark rights in the context of a CTM proprietorship. The second part of the chapter covers issues relating to the procedure for filing CTM applications, opposition against CTM registration and a Search procedure (as a means by which earlier trademark rights may be discovered). An analysis in the second part extends to some legal issues that may lead a CTM being cancelled either through revocation or invalidity proceedings. The second part concludes with a discussion on how international trademark registrations with effect in the Community are handled.

232 As Council Regulation (EC) No 40/94 published in OJ L 11, 14.1.1994, p. 1. This Regulation was repealed and replaced by Council Regulation (EC) No 207/2009 of 26 February 2009 on the Community trade mark (codified version).

233 The rights attached to the CTM are rights in rem. Cf. Article 19(1) of the CTMR.

$234 C f$. Article 6 of the CTMR. 
To give life to the discussion contained in the chapter, a brief introduction is offered on the office charged with a primary duty to ensure that the substantive principles and the procedure outlined in the CTMR are observed during the processing of CTM applications as well as opposition and cancellation proceedings.

\section{B. Office responsible for CTM system}

Article 2 of the CTMR establishes the office for the harmonisation in the internal market (trademark and designs), (hereinafter the Office or OHIM), as the chief office responsible for community trade mark registrations. As a body of the Community, OHIM enjoys a legal personality entitling it to acquire or dispose of real or movable property and be party to judicial proceedings while enjoying the most "extensive legal capacity accorded to legal persons" in each of the Member States. ${ }^{235}$ It carries out community objectives, which are in line with community law governing the internal market. OHIM is therefore expected to guide the national authorities as to how the community law in relation to trade mark registration is to be translated and carried out.

Within OHIM's functional structure established under Article 130 of the CTMR, five units are directly responsible for decisions affecting CTM registrability, namely, the examination, opposition, cancellation, administration and appellate divisions. Examiners, in the examination division, are responsible for examining absolute grounds for trademark refusal, ${ }^{236}$ whereas the Opposition Divisions are responsible for decisions on oppositions against CTM registration. ${ }^{237}$ The Cancellation Divisions are responsible for all decisions regarding application for revocation or application for declaration of invalidity. ${ }^{238} \mathrm{An}$ Administration of Trade Marks and Legal Division is responsible for deciding on all legal issues that do not fall within the competence of the above three divisions. Thus, the Administration Division is particularly responsible to take decisions on procedural matters. ${ }^{239}$ It is also duty bound to take decisions in respect of administrative issues such as those regarding "entries in the Register of Community trade marks". ${ }^{240}$ At the top of these four divisions are the Boards

$235 C f$. Article 115 of the CTMR.

$236 C f$. Article 131 of the CTMR.

237 Cf. Article 132 of the CTMR.

238 Cf. Article 134 of the CTMR.

239 KITCHIN, D., et al, "Kerly's Law of Trade Marks and Trade names" (4th ed.) 95 (Sweet \& Maxwell, London 2005).

240 GASTINEL, E. \& MILFORD, M., "The Legal Aspects of the Community Trade Mark" 
of Appeal, which are responsible for deciding appeals resulting from, inter alia, the examiners' decisions as well as appeals against the decisions of Opposition Divisions and Cancellation Divisions. ${ }^{241}$ An appeal involving a complex legal problem will normally be submitted before the enlarged Board of Appeal. ${ }^{242}$ While the Boards of Appeal are the final decision making authority within the organisational structure of OHIM, their decisions can only be challenged before the Court of Justice of the European Union (CJEU) (formerly designated as the European Court of Justice (ECJ)) and the General Court (GC) attached to the CJEU (formerly known as the Court of First Instance (CFI)). ${ }^{243}$ Article 257 of the Treaty on the Functioning of the European Union (TFEU) provides for the possibility that the Boards of Appeal become judicial chambers attached to the GC, "maintaining their seat in Alicante but outside OHIM's structure". ${ }^{244}$

\section{Subject matter of CTM protection}

Article 4 of the CTMR states, in relation to a definition of a CTM, that a sign which a trademark may consist of is "any sign capable of being represented graphically, particularly words, including personal names, designs, letters, numerals, the shape of goods or their packaging, provided that such signs are capable of distinguishing the goods or services of one undertaking from those of other undertakings".

Article 4 of the CTMR, therefore, incorporates graphical representation and distinguishing capability of a sign as formal and substantive requirements for CTM registration.

The definition under Article 4 of the CTMR complies with the minimum registration requirements enshrined in Article 15 of the agreement on TradeRelated Aspects of Intellectual Property Rights (TRIPS). By stipulating that "Any sign, or any combination of signs, capable of distinguishing the goods or services of one undertaking from those of other undertakings, shall be capable of constituting a trademark", Article 15 TRIPS accommodates the substantive and

52 (Kluwer Law International, The Hague 2001).

$241 C f$. Article 135 of the CTMR.

$242 C f$. Article 135(2) \& (3) of the CTMR.

$243 C f$. Articles 251 and 256 of the TFEU

244 BENDER, A. and KAPFF, P. von, "Born to be free - the Community Trade Mark in Practice", 32(6) IIC 625, 626 (2001), footnote 6. 
formal requirements for trade mark registration inscribed in Article 4 of the CTMR. $^{245}$

\section{Substantive requirement - the capability to distinguish}

It is generally accepted that many signs are capable of distinguishing goods and services. ${ }^{246}$ The requirement of distinctiveness in accordance with Article 4 of the CTMR is rather easy to meet. In this connection, Davies states that "[t]he Criterion which has to be applied is that of an abstract capability of distinguishing goods or services, which means that the sign has to be considered apart from the goods or services to which it relates." ${ }^{, 47}$ In practice, "no signs are per se excluded from being registered as a trade mark under Article 4 of the CTMR". ${ }^{248}$ The fact that capacity to distinguish is the core element in the definition under Article 4 of the CTMR reiterates the historic basis for trademark protection, which is to protect broadly trademarks as indicators of origin. ${ }^{249}$ However, a nonspecific subject matter considered to be concept-related, cannot be registered as a CTM for it has no capability to distinguish. In the Dyson case ${ }^{250}$ a transparent bin or collection chamber forming part of the external surface of a vacuum cleaner was held to be unregistrable. The ECJ's decision in this case was, inter alia, based on the ground that a transparent bin or a collection chamber is a concept (i.e. a mere property of the vacuum cleaner concerned) which could not be regarded as a sign under Article 4 of the CTMR, since it encompassed, "in a

$245 C f$. JACONIAH, J., "The Requirements for Registration and Protection of NonTraditional Marks in the European Union and in Tanzania", 40(7) IIC 756 (2009).

246 CORNISH, W. \& LLEWELYN, D., "Intellectual Property: Patents, Copyrights, Trade Marks and Allied Rights" (6th ed.) 696 (Sweet \& Maxwell, London 2007).

247 DAVIES, I. M. (ed.), "Sweet \& Maxwell's European Trade Mark Litigation Handbook" 36 (Sweet \& Maxwell, London 1998).

248 DAVIES, I. M. (ed.), "Sweet \& Maxwell's European Trade Mark Litigation Handbook" 36 (Sweet \& Maxwell, London 1998). See also Case C-273/00, Ralf Sieckmann [2002] ECR I-11737, para. 39 \& Case C-283/01, Shield Mark BV v. Joost Kist h.o.d.n. Memex [2003] ECR I-14313, paras. 34 and 35. See further Case C-104/01, Libertel Groep BV v. Benelux-Merkenbureau [2003] ECR I-3793, para. 23 and Case C-49/02, Heidelberger Bauchemie GmbH [2004] ECR I-6129, para. 22, which, in addition to reiterating the graphical representation and capability to distinguish as basic conditions a sign must fulfil in order to be registered, mention that the subject-matter of trademark application must be a "sign".

249 CORNISH, W. \& LLEWELYN, D., "Intellectual Property: Patents, Copyrights, Trade Marks and Allied Rights" (6th ed.) 688 (Sweet \& Maxwell, London 2007).

250 ECJ, 25 January 2007, Case C-321/03, Dyson Ltd [2007] ECR I-00687, paras. 37 to 40. 
general and abstract manner, all the conceivable shapes" of such a transparent bin or collection chamber.

\section{Formal requirement - the graphical representation}

The requirement that a registrable sign must be capable of being represented graphically, as stipulated under Article 4 of the CTMR, is reinforced under Article 26 of the CTMR, which requires an applicant for CTM registration to furnish OHIM with a representation of the trademark. ${ }^{251}$ The legal significance of the requirement for such a representation is mirrored by the fact that an application for trade mark registration may "claim special graphic features or colours, the use of small and capital letters and three dimensional marks" only through graphical representation. ${ }^{252}$

Graphical representation required under Article 4 of the CTMR does not mean actual reproduction of a sign in the register. Nevertheless, this is one methodology. The second method is to provide some contours representing the sign and some description enough to make the trademark examiner and other interested parties know what is claimed and the extent of the consequential monopoly. ${ }^{253}$

\section{Essence of the formal requirement}

A trademark protection regime must, as a matter of principle, encourage and foster the principle of legal certainty. ${ }^{254}$ A registered trade or service mark affords to its proprietor a monopoly over the exclusive use of the signs constituting such a trade or service mark. ${ }^{255}$ The use of a registered trade or service mark by third parties having no authorisation from the owner infringes the exclusive right(s) bestowed upon the right holder. The legal certainty, in

251 Article 26(1) (d) of the CTMR.

252 KOOIJ, P.A.C.E. van der, "The Community Trade Mark Regulation: An Article by Article Guide" 60 (Sweet \& Maxwell, London 2000). See also Rule 3(1) of the CTMIR.

253 DUMFARTH,P.,"Prozessuale und materiellrechtliche Aspekte des Widerspruchsverfahrens der Gemeinschaftsmarkenverordnung" 39 (Trauner, Linz 2008). Cf. also FEZER, K.-H., "Die Grafische Darstellbarkeite eines Markenformats" 44, in: BOMHARD, V. von, PAGENBERG, J. \& SCHENNEN, D., (eds.), "Harmonisierung des Markenrechts: Festschrift für Alexander von Mühlendahl zum 65. Geburtstag am 20. Oktober 2005" (C. H. Verlag, München 2005).

254 See the opinion of Advocate-General Ruiz-Jarabo Colomer in case C-273/00, Ralph Sieckman [2002] ECR I-11737.

$255 C f$. Articles 9 and 8 of the CTMR. 
relation to trade or service mark protection, should enable a person to know, through an inspection of the register the nature and scope of the signs protected as trade or service marks. This position is in line with a view that:

... the trade mark register is not supposed to be the result of an academic exercise in turning intangible concepts such as sounds and scents into words and pictures: it is a practical tool for any businessman who wants to go into business and who wants to know if he will get into legal trouble if he gives his goods a particular name, appearance, colour or smell. If the register cannot give him that information, it has failed in its primary objective. $^{256}$

The legal monopoly with respect to a trade or service mark is not granted automatically. Such monopoly is contingent upon the applicant furnishing the examiners with information sufficient to establish clearly what the signs are, which constitute a service or trade mark in question. The clarity and preciseness of this information make others aware of what they must refrain from doing in relation to a registered trade or service sign. This is the major reason why graphical representation (under the CTMR) of a sign in the register is mandatory.

\section{Formal and substantive requirements vis-à-vis non-traditional marks}

The standard required for the advancement of legal certainty under the CTMR is based on graphical representation. However, the CTMR does not give an exact and precise definition as to what the phrase "graphical representation" means. It only provides instances of signs that are capable of this kind of reproduction and representation. $^{257}$ Thus, it is pertinent to find out whether and how some new forms of trade symbols such as smells, sounds, colours and three dimensional marks ${ }^{258}$ are responsive of the formal and substantive requirements for trademark registration under the $\mathrm{CTMR}{ }^{259}$

256 Cf. PHILLIPS, J., “Trade Mark Law: A Practical Guide” 65 (OUP, New York 2003).

$257 C f$. Article 4 of the CTMR.

258 These signs are often referred to as non-traditional marks. For instance, while Sehirali Çelik uses the phrase in the article entitled „An overview of Turkish Case-Law on Trademark Disputes with Special Consideration Regarding the Rules of the European Court of Justice“, in 39(3) IIC 326 (2008); Ströbele refers to the same concept by using the phrase 'new trademark forms' in his article entitled "The Registration of New Trademark Forms", in 32(2) IIC (2001).

259 For an extensive discussion on graphical representation of the non-traditional marks see JACONIAH, J., "The Requirements for Registration and Protection of Non-Traditional Marks in the European Union and in Tanzania", 40(7) IIC 756 et seq. (2009). Cf. Also BENDER, A., "Die grafische Darstellbarkeit bei den neuen Markenformen" 157 et seq., in: BOMHARD, V. von, PAGENBERG, J. \& SCHENNEN, D. (eds.), "Harmonisierung 
However, it is important to mention one fact in the passing: there are no separate criteria for assessing the registrability of non-traditional signs. EU law, for example, does not require authorities to apply a stricter assessment of the registrability of new types of marks than it does for traditional marks. ${ }^{260}$

\section{Smells}

The EU trademark jurisprudence confirms that smells and sounds can be registered and function as trademarks. The case of Ralf Sieckmann ${ }^{261}$ is recorded to have broken new ground as far as registration of intangible mediums such as smells are concerned. As it was the first in a number of ECJ decisions dealing with unconventional trademarks, it has become the leading decision also with regard to sounds, colours and colour combinations ${ }^{262}$, where initially, the capability of being represented graphically was also considered as problematic, although there was little doubt as to such signs being generally capable of distinguishing goods or services. In the case concerned, the applicant, Mr. Sieckmann, had offered to the German Patent and Trade Mark Office (Deutsches Patent- und Markenamt) the following modes of representation of his olfactory mark:

Trade mark protection is sought for the olfactory mark deposited with the Deutsches Patent- und Markenamt of the pure chemical substance methyl cinnamate (= cinnamic acid methyl ester), whose structural formula is set out. ${ }^{263}$

In addition, Mr. Sieckmann had offered to deposit a sample of the smell for which registration was sought. It seems, in light of the first question that the German Patent and Trade Mark Office referred to the ECJ, that the opinion

des Markenrechts: Festschrift für Alexander von Mühlendahl zum 65. Geburtstag am 20. Oktober 2005" (C. H. Verlag, München 2005).

260 ECJ, 8 April 2003, Joined Cases C-53/01 to 55/01, Linde AG, Winward Industries Inc. \& RadoUhren $A G$ [2003] ECR I-03161, para.49.

261 ECJ, 12 December 2002, Case C-273/00, Sieckmann [2002] ECR I-11737.

262 See for example Case C-283/01, Shield Mark BV v. Joost Kist h.o.d.n [2003] ECR I14313, para. 28; ECJ, 24 June 2004, Case C-49/02, Case C-49/02, Heidelberger Bauchemie GmbH [2004] ECR I-06129, para. 25; Case C-104/01 Libertel Groep BV v. Benelux-Merkenbureau [2003] ECR I-3793, para. 28.

263 He added that "samples of this olfactory mark can also be obtained via local laboratories listed in the Gelbe Seiten (Yellow Pages) of Deutsche Telekom AG or, for example, via the firm E. Merck in Darmstadt." He also gave the structural formula C6H5-CH = CHHOOCH3 as a part of such description (Case C-273/00 Ralph Sieckmann [2002] ECR I-1173, para. 11). 
prevailed prior to Sieckmann ${ }^{264}$ that odours could neither be reproduced directly nor be perceived visually. In order to obtain clarification on this point, the German Patent and Trade Mark Office posed the question to the ECJ whether, in the light of Article 2 TD (which corresponds to Article 4 CTMR), smells which can in no way be perceived visually could be presumed to be capable of graphical representation if they are reproduced indirectly through certain aids. Based on a purposive interpretation of Article $2 \mathrm{TD}$, the ECJ concluded that since the list of signs capable of graphical representation contained in the Article does not claim to be exhaustive, odours and smells are not specifically excluded. For that matter, although smells are invisible, still they can be represented graphically "particularly by means of images, lines or characters". However, such representation must be "clear, precise, self-contained, easily accessible, intelligible, durable and objective". ${ }^{265}$

Consequently, not each mode of representation will constitute an acceptable graphical representation of an olfactory sign. Concerning the modes of representation offered by Mr. Sieckmann, ${ }^{266}$ the ECJ insists that "[in] respect of an olfactory sign, the requirements of graphic representability are not satisfied by a chemical formula, by a description in written words, ${ }^{267}$ by the deposit of an odour sample or by a combination of those elements". ${ }^{268}$ With regard to those representations, it is further observed that:

- Only few people would recognise in a formula the subject matter of a trademark application (in this case an odour).

- Description of an odour is graphic representation which is not "sufficiently clear, precise and objective". ${ }^{269}$ Moreover, "such a description is

264 However, the USA Patent Office has been registering olfactory signs and sounds, and the UK Patent and Trademark Office has been registering smell marks, before the Sieckmann decision $c f$. Case C-273/00 Ralf Sieckmann [2002] ECR I-11737, para.59).

265 Case C-273/00 Ralph Sieckmann [2002] ECR I-1173, para. 55.

266 Although description of an odour is graphic, it is not sufficiently clear, precise and objective (Case C-273/00 Ralph Sieckmann [2002] ECR I-1173, para. 70).

267 This position is contrary to that reached by the OHIM Board of Appeals in Vennootschap onder Firma Senta Aromatic Marketing's Application, Case R 156/19982 [1999] ETMR 429; and Myles Ltd's Application, Case R 711/1999-3, [2003] ETMR 718 (OHIM) in which the description in words 'the smell of fresh cut grass' and 'the scent of raspberries' were respectively held to be sufficient graphical representation since the smells concerned were well-known to the extent that any one perusing the register would easily recognise the smell concerned, hence further graphical representation were considered unnecessary.

268 Case C-273/00 Ralph Sieckmann [2002] ECR I-1173, para. 73.

269 Case C-273/00 Sieckmann [2002] ECR I-1173, para. 70. 
imbued with subjectivity and can be interpreted in a subjective way, that is, differently by different people". ${ }^{270}$

- Due to the fact that "an odour sample is not sufficiently stable or durable", deposit of such sample does not constitute a graphic representation for the purpose of Article 2 of the Directive". ${ }^{271}$

Viewed in light of the ECJ's observation above, "graphic representation seems sensibly to be limited to clear and easily determined means of describing sensations which can be appreciated by smell". ${ }^{272}$ The chance for such registrations to succeed is however minimal. Although OHIM had previously allowed registration of the smell of fresh-cut grass for tennis balls, ${ }^{273}$ it rather seems that, in view of the Sieckmann case, "unless and until there is a further ruling, no more smell marks can validly be registered in the EU". 274

\section{Sounds}

Regarding sound marks, the ECJ, in Shield Mark BV case, ${ }^{275}$ intimated that since sound signs are not by nature incapable of distinguishing the goods or services of one undertaking from those of other undertakings, Article 4 of the CTMR "must be interpreted as meaning that sounds may constitute a trade mark, on condition that they may also be represented graphically". ${ }^{276}$ Because in the Sieckmann case the ECJ had expounded the protectable subject matter enlisted in Article 4 of the CTMR to include signs which cannot be perceived visually but may be perceived through surrogate graphical representations, ${ }^{277}$ the Shield Mark case held that although sound signs are a category of marks that cannot be perceived visually, they may be registered as CTM provided that other conditions (such as graphical representation) are met. ${ }^{278}$

270 Case C-273/00 Sieckmann [2002] ECR I-1173, para. 65.

271 Case C-273/00 Sieckmann [2002] ECR I-1173, para 71.

272 W. CORNISH \& D. LLEWELYN “Intellectual Property: Patents, Copyrights, Trade Marks and Allied Rights" 691, 6th ed. (Sweet \& Maxwell, London 2007).

273 Cf. Vennootschap onder Senta Aromantic Marketing's Application [1999] ETMR 429.

274 FIRTH, A., et al, "Trade Marks - Law and Practice" (2nd ed.) 32 (Jordan Publishing, Ltd., Bristol 2005).

275 Case C-283/01, Shield Mark BV v. Joost Kist h.o.d.n [2003] ECR I-14313.

276 Case C-283/01, Shield Mark BV v. Joost Kist h.o.d.n [2003] ECR I-14313, paras. 36 and 37.

277 Case C-273/00 Ralph Sieckmann [2002] ECR I-1173, para 55.

278 Case C-283/01, Shield Mark BV v. Joost Kist h.o.d.n [2003] ECR I-14313, paras. 34 and 35 . 
Having established the view that sound signs are potentially capable of distinguishing goods or services within the ambit of Article 4 of the CTMR, the court proceeded with the decision as to which mode of graphical representation is suitable for such signs. The referring court had enumerated different forms of representation $^{279}$ and invited the ECJ to respond particularly on the suitability of those forms in respect of sound signs. In response thereto, the ECJ moved from an analogy that graphical representation (which may be effected by means of images, lines or characters) must be "clear, precise, self-contained, easily accessible, intelligible, durable and objective" ${ }^{, 280}$. It consequently concluded that:

In the case of a sound sign, those requirements are not satisfied when the sign is represented graphically by means of a description using the written language, such as an indication that the sign consists of the notes going to make up a music work, or the indication that it is the cry of an animal, or by means of a simple onomatopoeia, without more, or by means of a sequence of musical notes, without more. On the other hand, those requirements are satisfied where the sound is represented by a stave divided into measures and showing, in particular, a clef, musical notes and rests whose form indicates the relative value and, where necessary, accidentals. ${ }^{281}$

The ECJ did not rule upon the appropriateness of a sonogram as a means to represent sounds (e.g., the cry of animals) ${ }^{282}$. Hence, for the time being it is unclear in view of the Shield Mark case whether and how sound signs other than those consisting of a musical tune can meet the requirements for graphical representation, and thus for registration and protection as trademarks.

\section{Colours}

The EC trade mark regime ${ }^{283}$ provides for a possibility to register a single colour. The ECJ in case C-104/01 Libertel Groep BV v. Benelux-Merkenbureau addressed the question whether "a colour per se, not having any shape or contour" can constitute a trade mark within the meaning of the EC trademark directive. In response thereto, the ECJ clarified that a colour may be registered as a CTM, provided it meets the substantive and formal requirements for

279 Such as musical notes; a written description in the form of an onomatopoeia; a written description in some other form; a graphical representation such as a sonogram; a sound recording annexed to the registration form; a digital recording accessible via the internet; a combination of those methods; some other form and, if so, which?

280 Case C-283/01, Shield Mark BV v. Joost Kist h.o.d.n [2003] ECR I-14313, para. 55.

281 See Case C-283/01, Shield Mark BV v. Joost Kist h.o.d.n [2003] ECR I-14313, para. 2 of the operative part.

282 Although the question had been posed; see above, note 273.

283 Article 4 of the CTMR. 
registration. ${ }^{284}$ This clarification has now settled the position of EC law also with respect to the registration of a single colour mark: If used in relation to goods, a colour can serve as a trademark. Distinctiveness of a single colour is thus derived from prior use. In this sense, a colour per se cannot be inherently distinctive, unless some exceptional circumstances apply to it such as where the classes of goods (or services) in respect of which the mark is protected are very narrow and the goods are sold (or the services are offered) in a specific market. ${ }^{285}$

Distinctiveness is not the sole decisive requirement for the registration of a colour mark. A colour mark must additionally fulfil the requirements regarding the capability to be represented graphically in a manner that is clear, precise, self-contained, intelligible, durable and objective. ${ }^{286} \mathrm{~A}$ mere reproduction of a colour on a paper does not satisfy the requirement of graphical representation. However, the legal requirements are satisfied by a designation of a colour based on international identification code of the respective colour. ${ }^{287}$

The graphical representation of combination of colours may, as well, present some difficulties. The ECJ's holding in Heidelberg Bauchemie GmbH $H^{288}$ confirms that colours or combinations of colours may serve a trademark purpose. In this regard, however, a trademark proprietor must limit, through graphical representation, the extent of his protectable subject matter so as to meet the precision and durability requirements of the formal procedure for trademark registration. ${ }^{289}$ Graphical representation is not met by "the mere juxtaposition of two or more colours, without shape or contours, or a reference to two or more colours in every conceivable form". ${ }^{290}$ This is due to obvious reasons:

Such representations would allow numerous different combinations, which would not permit the consumer to perceive and recall a particular combination, thereby enabling him to repeat with certainty the experience of a purchase, any more than they would allow the competent authorities and economic operators to know the scope of the protection afforded to the proprietor of the trade mark. ${ }^{291}$

284 Case C-104/01 Libertel Groep BV v. Benelux-Merkenbureau [2003] ECR I-3793, para. 1 of the operative part.

285 Case C-104/01 Libertel Groep BV v. Benelux-Merkenbureau [2003] ECR I-3793, paras. 66 and 67. The concept of distinctiveness is discussed below in section D (I) (2) of this chapter.

286 Cf. Case C-104/01 Libertel Groep BV v. Benelux-Merkenbureau [2003] ECR I-3793, para. 1 of the operative part.

287 Cf. Case C-104/01, Libertel Groep BV v. Benelux-Merkenbureau [2003] ECR I-3793, para. 1 of the operative part.

288 Case C-49/02, Heidelberger Bauchemie GmbH [2004] ECR I-6129, paras. 40 and 41.

289 Case C-49/02, Heidelberger Bauchemie GmbH [2004] ECR I-6129, para. 32.

290 Cf. Case C-49/02, Heidelberger Bauchemie GmbH [2004] ECR I-6129, paras. 34 and 35.

291 Case C-49/02, Heidelberger Bauchemie GmbH [2004] ECR I-6129, paras. 34 and 35. 
Accordingly, the court rightly held that:

Colours or combinations of colours which are the subject of an application for registration as a trade mark, claimed in the abstract, without contours, and in shades which are named in words by reference to a colour sample and specified according to an internationally recognised colour classification system may constitute trade mark... where:

- It has been established that, in the context in which they are used, those colours or combinations of colours in fact represent a sign, and

- The application for registration includes a systematic arrangement associating the colours concerned in a predetermined and uniform way. ${ }^{292}$

\section{Grounds for Trade Mark Refusal}

To qualify for registration, a CTM must be subjected to absolute and relative grounds for trademark refusal. These grounds are respectively discussed in sections D(I) \& (II) of this chapter.

\section{Absolute Grounds}

While many signs may be used to market some products or services, not each of these trade symbols may withstand the rigorous registrability test stipulated under Article 7 of the CTMR. The Article serves as an absolute bar to registration of signs, which do not meet the requirements of Article 4 of the CTMR; or signs and indications which are generic, descriptive, non-distinctive and those signs covered under Articles 7(1) (f) - (k) of the CTMR. In summary, subparagraphs $(\mathrm{f})$ to $(\mathrm{k})$ prohibit the registration of signs which contravene public policy and/or good morals of the society; signs, the use of which is considered to be unauthorised use of emblems, badges or hallmarks; and geographical indications for wine not having that origin.

\section{Requirements of Article 4 of the CTMR}

Article 4 stipulates that, to constitute a CTM, a sign must meet both formal (capability to be represented graphically) and substantive (capability to distinguish goods and services) requirements. Article 7(1) (a) incorporates these requirements as absolute grounds for CTM refusal. Thus, the formal and 
substantive requirements for trademark registration under Article 4 of the CTMR each form a distinct absolute ground. ${ }^{293}$

\section{Distinctiveness}

The general principle underlying trademark protection is hinged on the requirement of distinctiveness. In this regard, the importance for trade signs to be distinctive is substantiated by the fact that a proprietor of a non-distinct symbol would unreasonably "prevent other producers from conveying important information to consumers" if he were allowed to monopolise the symbol by way of trade mark registration. ${ }^{294}$ Pursuant to Article $7(1)$ (b) of the CTMR, "trademarks which are devoid of any distinctive character" cannot be registered. This prohibition reflects the historic basis for trademark protection, namely "to protect marks as, in a broad sense, indicators of origin". ${ }^{295}$ Indeed, the limitation as to the signs capable of serving as trademarks contained in Article 7(1), highlights the significant role of the trade mark protection regime to prevent the grant monopoly rights in certain non-distinctive signs: If trade mark law did not put such a limit, consumers would, in reality, make many ignorant or blind purchase decisions due to want of concrete information regarding the origin and quality of the products. The limitation as to signs which can serve as trademarks provides a rational basis for economic justification of a trademark protection regime. $^{296}$

The main concern under Article 7(1) (b) of the CTMR is "not whether the sign has the potential of being distinctive, but if the trade mark as applied for is distinctive with respect to the goods and services to which it relates". ${ }^{297}$

The World Intellectual Property Organisation (WIPO) has also elucidated on the concrete distinctiveness required under Article 7(1) (b) by offering the following analysis:

293 Cf. Philips v Remington [1998] ETMR 124, 141.

$294 C f$. HORTWITZ, J. A., "Conflicting mark: embracing the consequences of the European Community and its unitary trademark regime" 18 Ariz. J. Int'l \& Comp. L.245, 254 (2001).

295 CORNISH, W. \& LLEWELYN, D., "Intellectual Property: Patents, Copyrights, Trade Marks and Allied Rights" (6th ed.) 688 (Sweet \& Maxwell, London 2007).

296 Cf. HORWITZ, J. A., "Conflicting marks: Embracing the consequences of the European Community and its unitary trademark regime”, 18 Ariz. J. Int'l \& Comp. L. 245, 253 (2001).

297 DAVIES, I. M., (ed.), "Sweet \& Maxwell's European Trade Mark Litigation Handbook" 37 (Sweet \& Maxwell, London 1998). 
Single tones or trivial sounds would not be perceived as distinctive signs, and the same would apply to a lengthy musical peace or a long play, even if it includes words. Following the principle of availability, sounds that would be regarded as common to the trade and required by other traders could not be registered as trademarks, for example, the sound of glass breaking in relation to "windscreen repair services" or well known classical music pieces in relation to "dancing tuition" services. However, many sounds have no particular descriptive relationship with the proposed goods or services and would be considered prima facie acceptable, for example, the sound of a "wolf howling" in relation to alcoholic beverages. ${ }^{298}$

The British Sugar plc case ${ }^{299}$, while interpreting Section 3(1) (b) of the United Kingdom Trade Marks Act 1994, which is similar to Article 7(1) (b) of the CTMR, elucidated the phrase "devoid of any distinctive character". According to the case, the phrase "devoid of any distinctive character" stands alone as a ground of exclusion from registration. It is nevertheless fallacious to discern that symbols which are not completely descriptive and therefore, not prohibited under Article 7(1) (c) of the CTMR, are distinctive. The phrase devoid of any distinctive character may still apply even where the signs concerned are neither descriptive nor generic. ${ }^{300}$ The recurrent objection against registration of trademarks on the "devoid of distinctive character" ground is in relation to surnames. In view of the holding in Unilever Plc's Application ${ }^{301}$ where registration of MISTER LONG regarded as surname in the United Kingdom was in issue; words possessing surnominal significance are "neither automatically eligible nor automatically ineligible for registration". Registration of names, and particularly of common surname, will generally be withheld unless it is clear to the registry that the name concerned has acquired distinctive character, hence its registration is not likely to extend unfair advantage to the first applicant for such a name. ${ }^{302}$

To establish whether a particular sign is devoid of any distinctive character (in relation to goods and services) it is inevitably needed to show that such sign has no potential characteristics that would allow the relevant consumers to draw a

$298 C f$. the analysis by WIPO's Standing Committee on the Law of Trademarks, Industrial Designs and Geographical Indications on the "Relation of Established Trademark

Principles to new types of Marks", Seventh Session (May 7 to 11, 2007) contained in SCT/17/3 dated 30 March 2007; available at $<$ www.wipo.int/edocs/mdocs/sct/en/sct_17/sct_17_3.pdf> (status: 30 July 2012).

299 British Sugar plc v. James Robertson \& Sons Ltd [1996] RPC 281.

300 CORNISH, W. \& LLEWELYN, D., "Intellectual Property: Patents, Copyrights, Trade Marks and Allied Rights" (6th ed.) 696 (Sweet \& Maxwell, London 2007).

301 [1999] E.T.M.R. 406

302 Cf. ECJ, 16 September 2004, Case C-404/02, Nichols plc [2004] ECR I-08499, para.12. 
distinction between the trade mark proprietor's goods and/or services and the products and/or services from a different commercial source. ${ }^{303}$

OHIM Examination Guidelines, particularly Guideline 8.3, ${ }^{304}$ also clarify the phrase "devoid of any distinctive character". It stipulates that:

The trademark must not be devoid of any distinctive character and must therefore, do more than describe the goods or services, whether in words or graphically. A word such as 'wine' in respect of wine is devoid of distinctive character. A trademark consisting one or two letters or digits, unless represented in an unusual fashion, would, except in special circumstances, be considered devoid of distinctive character. ... Simple signs such as circles or squares, whether on their own or in conjunction with descriptive elements, are generally considered to be devoid of distinctive character. Single, especially primary colours, of simple designs are usually devoid of distinctive character. Where a trade mark consists of a combination of several elements which on their own would be devoid of distinctive character, the trade mark taken as whole may have distinctive character. However, if a trade mark comprises nothing more than a combination of [a description, a generic sign or a functional shape] it is likely to be devoid of distinctive character.

It is noteworthy that the distinctiveness requirement is contained in both Articles 4 and 7(1) (b) of the CTMR. One may thus question whether, in view of the concept of distinctiveness as stipulated under Article 7(1) (b), the fusion of the requirements of Article 4 into Article 7(1) (a) is merely a repetition of the concept that any registrable mark must be capable of distinguishing goods or services of one origin from those tracing their origins from different sources; or whether the concepts in the two provisions differ. The EC legislature seems to have already provided an answer to this question, vide Article 7(3) of the CTMR. Within the ambit of this Article, the provisions of Article 7(1) (b), (c) and (d) do not, but only 7(1) (a), apply while assessing registrability of a sign which upon being used on the market acquires a secondary meaning in relation to goods and services corresponding to those in respect of which a CTM registration is sought. $^{305}$ This clarification throws some light to the main difference between paragraphs (a) and (b) of Article 7. In the circumstances, a sensible conclusion may be drawn to the effect that while Articles 4 and 7(a) of the CTMR connote "a general, absolute, abstract capacity to distinguish products of different

Celltech R\&D Ltd v. OHIM, 37(2) IIC 225, 226 (2006).

304 OHIM OJ 9/96, p. 1331.

305 Acquisition of a distinctive character as a consequence of the use of a mark requires that at least a significant proportion of the relevant section of the public identifies products or services as originating from a particular undertaking because of the mark (cf. CFI, 29 April 2004, Case T-399/02, Eurocermex v OHIM ('Botella Corona') [2004] ECR II391, para. 42). That use must be demonstrated in substantial part of the Community where the mark is devoid of any distinctive character within the meaning of Article 7(1) (b) of the CTMR (cf. CFI, 15 December 2005, Case T-262/04, BIC SA v OHIM [2005] ECR II-5959, para. 62). 
origins," Article 7(b) refers to CTM's distinctiveness in view of the class of goods or services marketed under the CTM in question. ${ }^{306}$ Thus, by incorporating the provisions of Article 4, Article 7(1) (a) intends fundamentally to bar registration of signs, which are generally considered to be incapable of serving as a trademark, whereas the prohibition enshrined under Article 7(1) (b), (c) and (d) excludes from registration signs, which do not meet a specific condition enshrined under Article 4 of the CTMR, namely, the capability to distinguish. ${ }^{307}$

Judged in terms of cogency, the stipulation on distinctiveness under Article 4 , being an abstract requirement, must be observed just as a matter of theory, 308 whereas that under Article 7(1) (b) of the CTMR may be waived provided that Article 7(3) applies to the mark in question.

The concept of "fair play underscores the purpose and necessity of trademark law". ${ }^{310}$ Article $7(1)$ of the CTMR is a vehicle through which a fair play in the marketplace may be brought about. Indeed, the need for symbols to be distinctive is reinforced by the fact that the owner of non-distinctive signs would prevent other business operators from conveying products or services information to consumers. While monopolisation of a non-distinctive trade sign would unfairly shield the proprietor against competition, "consumers would have great difficulty in identifying alternatives from the non-distinctive mark owner's goods, and in turn, would end up making misinformed purchases". ${ }^{311}$ Thus, by prescribing some guidelines for registrability of a CTM, Article 7(1) tends to balance the public interests against an unwarranted trademark monopoly.

Frequently, the ECJ has held that "in order to determine whether a sign presents a characteristic such as to render it registrable as a trade mark, it is

306 Cf. SAT.1 Satellitenfernsehen GmbH v. OHIM [2005] 1 C.M.L.R. 57.

307 Cf. MANIATIS, S. M., (2003), "Whither European Trade Mark Law? Arsenal and Davidoff: The Creative Disorder Stage", 7 Marq. Intell. Prop. L. Rev. 99, 109 (2003).

308 Since it has been held that "there is no class of marks having a distinctive character by their nature or by the use made of them which is not capable of distinguishing goods or services" within the meaning of Article 4 of the CTMR (Cf. Case C-299/99, Koninklijke Philips Electronics NV v. Remington Consumer Products Ltd. [2002] E.C.R. I-05475, para. 39).

309 Article 7(3) excludes application of Article 7(1) (b) by allowing registration of a mark, which would otherwise be prohibited under Article 7(1) (b).

310 HORWITZ, J. A., "Conflicting marks: Embracing the consequences of the European Community and its unitary trademark regime", 18 Ariz. J. Int'l \& Comp. L. 245, 249 (2001).

311 HORWITZ, J. A., "Conflicting marks: Embracing the consequences of the European Community and its unitary trademark regime", 18 Ariz. J. Int'1 \& Comp. L. 245, 252 (2001). 
appropriate to take the view point of the relevant public". 312 Consequently, each of the grounds for trademark refusal stipulated under Article 7 (1) attracts varied public interests; hence, these grounds have to be considered differently. ${ }^{313}$ It has, for instance, been held that the public interest underlying Article 7(1) (b) of the CTMR cannot be severed from the trademark's basic function, which is "to guarantee the identity of the origin of the marked product to the consumer or end-user by enabling him, without any possibility of confusion, to distinguish the product or service from others, which have another origin". "314 This position tends to highlight that the public interest underlying Article 7(1) (b) is to prohibit registration of signs, which are devoid of any distinctive character ${ }^{315}$ - a solitary fact, which renders the signs concerned incapable of performing the trademark's basic function.

\section{Descriptiveness}

Signs or indications are descriptive "if they are inevitably suggested by some quality of the product or business". 316 The general prohibition under Article 7(1) (c) of the CTMR applies to the signs, which exclusively serve to describe or indicate the goods and services by referring to the nature (and/or properties of the use intended) of the goods concerned. ${ }^{317}$ In case the "mark does no more than describe the type or quality of product on offer", it is descriptive of those products, and hence cannot fulfil the function of indicating the origin of that

312 Cf. Lloyd Schuhfabrik Meyer [1999] E.C.R. I-3819, para. 26; and Case C-104/01, Libertel Groep BV v. Benelux-Merkenbureau [2003] ECR I-3793, para. 46.

$313 C f$. ECJ decision, April 29, 2004, joined cases C-456 P and C- 457/01 P, Henkel KGaA v. OHIM [2004] ECR I-05089, paras. 45 and 46.

314 Cf. Hoffmann-La Roche [1978] E.C.R. 1139, para. 7 and Koninklijke Philips Electronics NV v. Remington Consumer Products Ltd. [2002] E.C.R. I-5475, para. 30.

315 The public interest demand that symbols which lack distinctive character should not be registered as trademarks ( $c f$. SAT.1 [2005] 1 C.M.L.R. 57, para. AG19). In view of "legal certainty and sound administration" stressed in Canon [1998] E.C.R. I-5507, para. 28 , it is important to exclude non-distinctive marks from registration since their registration could be challenged.

316 MCKEOUGH, J., STEWART, A. \& GRIFFITH, P., "Intellectual Property in Australia" (3rd ed.) 458 (LexisNexis Butterworths, Sidey 2004). The sign "soap" for instance, is a descriptive term; hence, cannot be registered for soap business. Nevertheless, such a sign upon passing a test of acquired distinctiveness or secondary meaning may be distinctive in respect of clothing (CORNISH, W. \& LLEWELYN, D., "Intellectual Property: Patents, Copyrights, Trade Marks and Allied Rights" (6th ed.) 689 (Sweet \& Maxwell, London 2007).

317 Telefon \& Buch VerlagsgmbH v. OHIM [2001] 3 C.M.L.R. 3. 
product. ${ }^{318}$ The CTMR ${ }^{319}$ does not allow such signs to be monopolised by way of trademark registration. It prefers that the signs of this kind ${ }^{320}$ be freely available to all instead of being reserved for one undertaking alone. There could, for instance, be good reasons for disallowing a monopoly in respect of descriptive word mark 'green' for any environmental conservation-related activity. ${ }^{321}$ In a different scenario, a combination of descriptive words may be registered as a CTM if it creates an impression which is different from that produced by the literal meaning of the word elements of the combination. ${ }^{322}$

Refusal of trademark registration will therefore be justified if the sign concerned induces the public, "immediately and without further thought, to perceive a description of the goods and services for which registration is sought". ${ }^{323}$ To identify whether a particular trade symbol is descriptive of the goods' or services' nature, quality or properties, the examiner has to make an assessment in light of the extent to which the consumers are likely to associate such symbol with the goods or services marketed under it. In FON WIRELESS Limited case, ${ }^{324}$ for instance, the sign FON was denied registration. The registration had been sought in relation to communications software, wireless communication systems and devices, transmission equipment for communication via internet, on-line or via computer network (class 9); provision of communications services (class 38); and design and development of communications software and equipment (class 42). The board of appeal held that "the sign 'FON' was a German way of writing 'PHONE' which is derived from the old Greek word 'PHON' which means sound" and used in German as an abbreviation for word Telefon (Telephone). It was found that when "FON" used for the goods and the services in relation to which it was applied for, it would serve as a description of the nature or of the intended purpose of the goods and/or the services concerned.

318 MCKEOUGH, J., STEWART, A. \& GRIFFITH, P., "Intellectual Property in Australia" (3rd ed.) 523 (LexisNexis Butterworths, Sidey 2004).

319 Article 7(1) (c) of the CTMR.

320 Descriptive signs and other indications mentioned in Article 7 (1) (c) of the CTMR.

321 F. GIOIA, "Alicante and the Harmonization of Intellectual Property Law in Europe" 41(1) CML Rev. 975, 981 (2004).

322 Cf. ECJ, 12 February 2004, Case C-265/00, Campina Melkunie BV v BeneluxMerkenbureau, [2004] ECR I-01699, para. 43. Cf. also the decision of OHIM's Board of Appeal in Case R 0793/200-1.

323 OHIM, 29 April 2008, Case R 49/2008-4 D.C.M.S., Inc. ('DATA CENTER WORLD'), para. 11. Cf. also CFI, 20 March 2002, Case T-355/00, DaimlerChrysler AG v OHIM ('Tel Aid') [2002] ECR II-1939, para. 28.

324 OHIM, 29 April 2008, Case R 1744/2007-5, FON WIRELESS Limited. 
In D.C.M.S., Inc case ${ }^{325}$ a firm position regarding descriptiveness of neologism signs was reiterated. There, OHIM's Board of Appeal stated that "a sign consisting of neologism or a word composed of elements each of which is descriptive of the characteristics of the goods or services in respect of which registration is sought", itself remains descriptive of those goods or services within the meaning of Article 7(1) (c) of the CTMR. ${ }^{326}$ Consequently, the sign 'DATA CENTER WORLD' (Whose registration was sought in respect of Class 35 (i.e. provision of extensive information about the field of data bases, a substantial area of information technology on a professional organised basis)) could not be registered for it consists of a combination of elements each of which is descriptive of the services covered by the said sign. Such a sign (i.e. the word mark 'DATA CENTER WORLD') is not an allusive combination of words to which a meaning different from its individual elements can be attached. Thus, the word 'WORLD' contextualised in light of "the elements 'DATA CENTER' clearly refers to an event where information and services in the field of data centres is the subject matter". ${ }^{327}$ The relevant public (i.e. English speaking people) would therefore perceive the expression as referring to services in respect of which registration of the sign was sought (i.e. provision of extensive information about the field of data bases, a substantial area of information technology on a professional organised basis) rather than the company owning the mark.

Similarly, in Telefon \& Buch Verlagsgmbh v. OHIM ${ }^{328}$ an application for registration of "UNIVERSALTELEFONBUCH and UNIVERSAL COMMUNIKATIONSVERZEICHNIS" trademarks was refused under Article 7(1) (c) because they tended to describe the goods and services. Registration of the marks was sought in respect of "recorded media for data processing installations and apparatus, in particular tapes, discs, CD-ROMs (class 9); printed matter, reference works (class16); publishing services, in particular the publication of texts, books, magazines, newspapers (class 41); editing of written texts (class 42)". Semantically construed, the German words in the mark mean universal telephone directory and universal communication directories. In view of this translation, the court observed that the mark described the goods and services in respect of which registration was sought. para. 12.

327 OHIM, 29 April 2008, Case R 49/2008-4 D.C.M.S., Inc. ('DATA CENTER WORLD'), para. 20. 
Jurisprudence regarding trademarks prone to be barred from registration under Article 7(1) (c) is very rich also in respect of geographical designations. ${ }^{329}$ According to ECJ's decision in Windsurfing Chiemsee case ${ }^{330}$, the prohibition against registration of geographical names stipulated under Article 7(1) (c) of the CTMR applies in two main scenarios, namely; where the relevant class of persons associate the place designated by the geographical name in question with the category of goods; and where, currently, there is no such association, the possibility that the geographical name may be used in future by the "undertakings concerned as an indication of the geographical origin of that category of goods".

An exception to the general rule regarding prohibition of registration of descriptive terms applies with respect to collective marks. Collective marks are normally registered to describe some quality and characteristics of goods. Registration of geographical names or indications of origin as Community collective marks is nevertheless allowed under Article 66(2) of the CTMR. This is not a contravention of the provisions of Article 7(1) (c) of the CTMR. Article 7(1) (c) proscribes registration of a descriptive term, as a trade mark, only to avoid a monopoly right to exclude others, which is customarily extended to a distinctive mark, being unfairly conferred to a proprietor of a descriptive sign: A registrant of a Community collective mark has no right to prevent third parties entitled to use a geographical name from using a Community collective mark based on such a geographical name. ${ }^{331}$

Even where indications which designate the geographical origin of goods are excluded from registration based on Article 7(1) (c), such exclusion cannot be

329 For extensive coverage on the registrability of geographical designations and how they can be used to challenge registration of CTMs and vice versa, see BEIER, F.-K., "Der Schutz geographischer Herkunftsangaben in Deutschland" 65(4) GRUR 169 et seq. (1963); HACKER, F., et al, "Das Verhältnis zwischen Marken und geographischen Herkunftsangaben (Q 191)", 55(8/9) GRUR Int 697 et seq. (2006); HEATH, C., "Parmigiano Reggiano by another Name: the ECJ's Parmesan Decision", 39(8) IIC 951 et seq. (2008); and EVANS, G.E., "The Comparative Advantages of Geographical Indications and Community Trade Marks for the Marketing of Agricultural Products in the European Union", 41(6) IIC 645 et seq. (2010).

330 Joined cases C-108/97 and C-109/97, Windsurfing Chiemsee Produktions- und Vertriebs GmbH v. Boots- und Segelzubehor Walter Huber and Attenberger [1999] E.C.R. I-2799, para. 37.

$331 C f$. MÜHLENDAHL, A., "Die Gemeinschaftsmarke" 29 (Staempfli Verlag AG, Bern 1998). Cf. also the last sentence of Article 67(2) of the CTMR pursuant to which any person whose goods or services originate in the geographical area concerned has a right to become a member of the association owning the Community collective mark. This is one of the conditions to which the use of collective mark is subjected. 
endorsed if the indication of geographical origin fulfils the conditions enshrined under Article 7(3). ${ }^{332}$

The public interests underlying Article 7(1) (c) is to the effect that "descriptive signs or indications relating to characteristics of goods or services in respect of which registration is sought may be freely used by all". ${ }^{333}$ The public interest stipulated under Article 7(1) (c) is nonetheless distinguishable from that accompanying registrability of some special categories of marks, such as a colour, which is assessed in light of the provisions of Article 7(1) (b). The public interest appreciated in Libertel ${ }^{334}$, for instance, was hinged on the need not to unduly restrict the availability of colours for other traders providing goods or services of the type in respect of which registration is sought. Thus, the public interest regarding restorability of colour marks envisages the fact that because there is a limited number of colours, giving a blanket monopoly in respect of colour marks would unnecessarily restrict other traders from enjoying the marketing advantage of a particular colour. Jeremy Phillips is more elaborate on the point. He states that:

The notion of avoidance of undue restriction is an interesting one, since in Libertel it appears to have evolved as response to the fact that the range of colours is itself the object of the limitation. If all telephone equipment is black, a trader who chooses to sell telephones that are orange may rightly be able to claim that his use of orange serves the function of indicating the identity of the origin of his telephone without actually inconveniencing any of his competitors. Yet by the time there are eight or nine makes of coloured telephone on the market, each having argued that its choice of colour is a unique means of identifying the source of that product, we suddenly find that we are approaching a situation in which subsequent market entry is barred to others because no telephone colour remains (except perhaps black for "generic" phones) that is not either (i) monopolised by an existing trader or (ii) similar to a colour monopolised by an existing trader. $^{335}$

Some legal opinion tends to draw a sharp distinction between the public interest underlying Article 7(1) (b) (i.e. the need not to unduly restrict availability of marks) and Article 7(1) (c) (i.e. signs or indication may be freely used by all). ${ }^{336}$ Nevertheless, a critic's eye may spot a point where the public interests in the two provisions converge. It is no doubt true that within the ambit of Article 7(1) (c) trade signs which exclusively serve to designate geographical origin of the goods

332 These conditions relate to the concept of secondary meaning or acquired distinctiveness which is considered in section D (I) (7) infra.

333 Cf. Windsurfing Chiemsee [1999] E.C.R. I-2799, at [25]; Linde and others [2003] E.C.R. I-3161, para. 73 and point 2 of the operative part.

334 Libertel Groep [2003] ECR I-3793, paras. 44 to 60.

335 PHILLIPS, J., "Trade Mark Law and the Need to Keep Free", 36(4) IIC 389, 393(2005).

336 See SAT.1 Satellitenfernsehen GmbH v. OHIM [2005] 1 C.M.L.R. 57, para. AG26. 
or services are excluded from registration because the public interest behind such a provision is to let indicators of geographical origins available for the use by other traders. However, a broad view would lead to a conclusion that, as the case is with the colour mark, geographical indications are limited in number, ${ }^{337}$ hence, a blanket monopolisation would unduly restrict a particular section of the society from using such indications in the marketplace. Thus, the distinction between the public interests under paragraphs (b) and (c) of Article 7(1) are more semantic and apparent than real. ${ }^{338}$

\section{Generic Signs}

Generic signs are, by their general nature, distinctive but due to excessive generic use in the course of time and trade lose their distinctiveness. A term which is initially non-descriptive of the goods or services for which it is used may later acquire a meaning that makes it generic. This phenomenon can be explained: "Just as a descriptive sign can become distinctive by its use as a trade mark, so a trade mark can lose distinctiveness through misuse as a product description". ${ }^{339}$ This opposite trail, in relation to generic marks, becomes eminent when trademarks of new products appearing in the market for the first time are not referred to by the generic name; but later on the trademarks become customary in the language to the extent that consumers do no longer regard the marks as a designation of origin, rather as the name of the products. Essentially, success of numerable trademarks increases a chance for these marks to lose distinctiveness and thus becoming generic. Famous examples regarding this fact can be cited: "SELLOTAPE, ASPRIN, ESCALATOR, HOOVER, FRIGIDAIRE, TERYLENE, FORMICA and THERMOS". ${ }^{340}$

Article 7(1) (d) of the CTMR bars registration of generic trademarks. According to the Article, "trade marks which consist exclusively of signs or indications, which have become customary in the current language or in the bona fide and established practices of the trade" shall not be registered.

337 Since in a particular geographical location there can only be one geographical designation/or indication, such indications are even fewer than colours.

338 Both colour and geographical designations need to acquire secondary meaning in respect of goods and services as condition for the grant of a trademark monopoly to individuals.

$339 C f$. FIRTH, A., et al, "Trade Marks - Law and Practice" (2nd ed.) 35 (Jordan Publishing, Ltd., Bristol 2005).

340 Cf. SHYLLON, F., "Intellectual Property Law in Nigeria" 189 IIC Studies Vol. 21 (Verlag C. H. Beck, München 2003). 
Merz \& Krell GmbH \& Co., case ${ }^{341}$ demonstrates one of the instances where the ECJ ceased an opportunity to discuss the issue concerning registration of a generic sign. A question regarding restorability of a word mark "BRAVO" arose in the above case. The German Patent and Trade Mark office refused registration of the word "BRAVO" for typewriters. The court based its decision on Article 3(1) (d) of the Community trade mark directive, which is similar to Article 7(1) (d) of the CTMR, on the ground that such word constituted a term of praise or an advertising slogan in respect of "writing implements" whose source of supply was sought to be designated by the word mark in question. The case went up to the German Federal Patent Court (Bundespatentgericht). The federal court encountered some difficulties in interpreting the provisions of Article 7(1) (d) of the CTMR, and thus asked the ECJ to throw some light on the matter. The federal court framed the following question:

Is Article 3(1) (d) of First Council Directive ... to be interpreted restrictively, contrary to the wording thereof, as meaning that only signs or indications which directly describe the specific goods and services in respect of which registration is sought, or the essential characteristics of features thereof, are affected by the bar to registration? Or is the provision to be construed as meaning that, in addition to generic signs and names, signs or indications which have become customary in the current language or in the bona fide and established practices of the trade in the relevant or a similar sector as advertising slogans, indications of quality or of incitements to purchase etc., without directly describing specific characteristics of the goods or services in respect of which registration is sought, may likewise not be registered?"342

In response thereto, the ECJ reasoned that the reliance on the provisions of Article 7(1) (d) of the CTMR only excludes "registration of a trade mark where the signs or indications of which the mark is exclusively composed have become customary in the current language or in the bona fide and established practices of the trade to designate the goods or services in respect of which registration of that mark is sought". ${ }^{343}$

Regarding registrability of the word mark "BRAVO", some authorities have been quick to point out that the sign, in principle, is regarded as an exclamation mark in most languages of the EC Member States. While it may be unsound to deny registration of the sign for "typewriters", it would be tenable to withhold

341 Case C-517/99, Merz \& Krell GmbH \& Co., v. Deutsches Patent- und Markenamt [2001] E.C.R. I-6959.

342 Case C-517/99, Merz \& Krell GmbH \& Co., v. Deutsches Patent- und Markenamt [2001] E.C.R. I-6959, para. [16].

343 Case C-517/99, Merz \& Krell GmbH \& Co., v. Deutsches Patent- und Markenamt [2001] ECR I-6959, para. 31. 
the grant of monopoly for "goods or services in the field of sports where the exclamation was used habitually". 344

\section{Shape Marks}

Shapes of goods may constitute a sign registrable as a trademark within the meaning of Article 4 of the CTMR. However, for a shape to be registered, besides meeting the requirements of graphical representation and capability to distinguish, it must not be one of the signs excluded from registration by Article 7(1) (e) of the CTMR. Thus, the three-dimensional shape of a product mark must, like any other category of trade mark, be examined for compliance with all the conditions listed in the Article mentioned in the immediately preceding sentence, and that these conditions must be construed and applied in the light of the public interest underlying each one. ${ }^{345}$ Article $7(1)$ (e) of the CTMR states that "signs which consist exclusively of the shape which results from the nature of the goods themselves ${ }^{346}$ or which is necessary to obtain a technical result ${ }^{347}$ or which give substantial value to the goods" cannot be registered. ${ }^{348}$ The Article concerns therefore, certain signs which, as a matter of principle, should not constitute trademarks and hence cannot be accommodated in a CTM register. ${ }^{349}$ In this way, Article 7(1) (e) contributes to the realisation of one of the principal aims of the trade mark protection regime, namely, to prevent monopolisation of

344 MANIATIS, S., "Trade Marks in Europe: A Practical Jurisprudence" (1st ed.) 229 (Sweet \& Maxwell, London 2006).

345 ECJ, 8 April 2003, joined cases C-53/01 to C-55/01, Linde AG, Winward Industries Inc. \& RadoUhren $A G$, [2003] ECR I-03161, para. 76.

346 A shape of a bicycle tube is an example of the shape resulting from the nature of the goods themselves. It would be unfair to grant a monopoly to one individual for such a shape. Granted, that kind of monopoly would unreasonably contravene the legitimate expectations of other traders to legitimately use such a shape in course of their business.

347 The shape under this category would be the shape of a propeller shaft or a fan. These instruments have to retain their form in order to function as they should.

348 This refers to the aesthetic appearance of the mark. While it is true that such an aesthetic appearance may be instrumental to enable a consumer reach a particular conclusion as to whether he may buy the goods or not, still such aesthetic features are not protectable as trademarks. However, such a shape may be protected under other branches of intellectual property such as design law. Moreover, pursuant to the Statement No 5 of the Joint Statements ([1996] O. J. O.H.I.M 613.); "Article 7(1) (e) applies to both the shape of the goods and that of their packaging, although this is not expressly mentioned in the provision" ( $c f$. DAVIES, I. M. (ed.), "Sweet \& Maxwell's European Trade Mark Litigation Handbook" 39 (Sweet \& Maxwell, London 1998).

349 Case C - 371/06 Benetton Group SpA v G-Star International BV [2007] ECR I07709,para. 26. 
certain shapes whose elements cannot be isolated from the products bearing those shapes and hence the need for the shapes concerned to be freely accessible by competitors. ${ }^{350}$ Concept-related shapes may be singled out as an example of the shapes covered under Article 7(1) (e) of the CTMR: This kind of shapes cannot be regarded a trade mark sign per se for they are more related to technical solutions (such as technical inventions whose protection is the concern of patent law) or functional characteristics of a product (which makes the shape generic and thus unregistrable as a trade mark). ${ }^{351}$

A proper decision by a trade mark examiner to refuse registration of a shape which results from the nature of the goods themselves within the ambit of Article 7(1) (e) of the CTMR cannot be overruled. Rigorous examination is required before the examining officer concludes as above: It is not an easy task to determine that a particular shape results from the nature of the goods, unless the goods concerned are the products of nature, such as pineapples and coconuts. ${ }^{352}$ Whereas a sign consisting of the shape of coconut for coconuts would be a shape which results from the nature of the goods themselves, the three-dimensional appearance of a bar of soap with longitudinal curved indents in the sides cannot be held to result from the nature of the soap itself. ${ }^{353}$ Assuming that the word 'nature' is to be taken literally, an orange's shape cannot be registered (for oranges) as a CTM for it results from the nature of oranges. Nevertheless, if the goods were orange juice, it is likely that an orange shape would, subject to the provisions of Article 7(1) (b) \& (c) of the CTMR respectively, ${ }^{354}$ be registered. Similarly, since "a liquid can have any shape, the shape of a container for liquids does not arise from the nature of the goods themselves" hence such a shape can be registered as a CTM.

In its judgment in Koninklijke Philips Electronics NV v. Remington Consumer Products Ltd ${ }^{356}$, the ECJ has commented upon the clause excluding from

350 DAVIES, I. M. (ed.), "Sweet \& Maxwell's European Trade Mark Litigation Handbook" 39 (Sweet \& Maxwell, London 1998).

351 Case C- 321/2003 Dyson Ltd v Registrar of Trade Marks [2007] ECR I-00687, para. 29.

352 KITCHIN, D., et al, "Kerly's Law of Trade Marks and Trade names" (4th ed.) 205 (Sweet \& Maxwell, London 2005).

353 CFI, 16 February 2000, Case T-122/99, The Procter \& Gamble Company v OHIM (SOAP), [2000]E.C.R. II - 265; [2000] E.T.M.R. 580.

354 In connection with this provision and since an orange's shape is naturally descriptive of orange juice and hence, not inherently distinctive; such a shape would only be registered for orange juice business upon acquisition of secondary meaning.

355 GASTINEL, E. \& MILFORD, M., "The Legal Aspects of the Community Trade Mark" 74 (Kluwer Law International, The Hague 2001).

356 ECJ, 18 June 2002, Case C-299/99 Philips v Remington. The material facts of the case 
protection product shapes consisting exclusively of the shape of goods, which is necessary to attain a technical result. ${ }^{357}$ In the previous literature, it had frequently been held that "a shape is only necessary to obtain a certain technical result when there are no equivalent alternatives to it for obtaining the same technical result". ${ }^{358}$ However, in Philips v. Remington, the ECJ clarified that the ground for refusal or invalidity of registration based on technical functionality of a shape cannot be overcome by establishing that there are other shapes which allow the same technical result to be obtained. The configuration of the electric shaver that was the object of the underlying conflict was therefore found to be excluded from protection. The same conclusion was drawn by the Grand Board of Appeal at OHIM regarding the LEGO building block and confirmed by the CFI. ${ }^{359}$ Where shapes are excluded for technical reasons, this applies even where people are inclined to think that the respective shape "looks good", for such a shape "is not there to indicate a connection with a trade mark owner but to do a job of work". 360

reveal that the bone of contention in the case was the use, by manufacturing and selling, by Remington, of an electric razor (in the UK) whose shape was similar to Phillips' shape mark (registered in the UK) made up of three rotary shaving heads set in an equilateral triangle on the shaving surface of the shaver. Basing on its trademark rights in the shape and configuration of the head of an electric shaver, Phillips sued Remington for trademark infringement. Remington counterclaimed and sought revocation of Phillips' registered rights in respect of the contentious shape. The High Court of Justice of England and Wales, Chancery Division (Patents Court) (United Kingdom) ordered revocation of Phillips' trade mark on the ground that the subject matter of trademark protection was devoid of any distinctive character and consisted of "a sign which served in trade to designate the intended purpose of the goods and of a shape which was necessary to obtain a technical result and which gave substantial value to the goods". Phillips appealed, against the High Court's decision, to the Court of Appeal (England and Wales) (Civil Division), which decided to refer the case to the ECJ as the arguments of the parties raised questions relating to the interpretation of Article 3(1) (e) of the TD.

357 The concept 'shape of the good necessary to obtain a technical result' may be likened "to the must-fit exclusion in design-right protection" where "[There] is no design freedom if a shape is dictated by the external need of fitting in with other part" ( $c f$. HAYS, T., "Distinguishing Use Versus Functional Use: Three Dimensional Marks" 97, in: PHILLIPS, J. \& SIMON, I. (eds), "Trade Mark Use”, (Oxford University Press, New York 2005).

358 DAVIES, I. M., (ed.), "Sweet \& Maxwell's European Trade Mark Litigation Handbook" 39 (Sweet \& Maxwell, London 1998).

359 Case T-270/06, LEGO Juris A/S v. OHIM., [2008] ECR II-03117, para. 13. Regarding the decision of the Grand Board of OHIM, cf. Case R856/2004 G, LEGO Juris A/S v MEGABRANDs Inc., [2007] ETMR 169.

360 PHILIPS, J., "Trade Mark Law: a Practical Anatomy" 146 (Oxford University Press, Oxford 2003). 
Shapes further remain unregistrable if they exclusively give substantial value to the goods. A product shape "gives substantial value to the goods if the shape in itself has intrinsic value, for example, if the product has a particularly elaborate design", in which case "protection may often be sought for the design as such". 36

Three dimensional shapes must, therefore, "satisfy the general tests of distinctiveness, under which inherent objections are balanced against evidence of use as an indication of origin" and that "shape, just as much as other product ingredients such as colour, patterning or smell, is not inherently distinctive as a mark" for "whatever form it takes, it will usually require considerable evidence of use before it can be registered". 362

Thus, where the shape possesses special characteristics as a result of which the public perceives such shape as departing from the usual and expected shape of the category of the product concerned it can neither be held to be part of the public domain nor denied registration. These special characteristics may be achieved through an application to the respective product shape or its packaging of two-dimensional features such as verbal or figurative elements and colours ${ }^{363}$ necessary to trigger a special impression produced by the three dimensional architecture.

\section{Further absolute grounds - Article 7(1) (f) - (k)}

Article 7(1) (f) of the CTMR prohibits the granting of legal monopoly in respect of signs whose registration would be contrary to public policy or accepted principles of morality; whereas Article 7(1) (g) of the CTMR excludes from registration as a CTM those trade symbols which are of such a nature as to deceive the public, for instance, as to the nature, quality or geographical origin of the goods or services.

Whether or not some signs contravene public policy or morality, it is the question for the court to address. The use of religious symbol such as "hallelu-

361 DAVIES, I. M. (ed.), "Sweet \& Maxwell's European Trade Mark Litigation Handbook" 39 (Sweet \& Maxwell, London 1998).

362 CORNISH, W. \& LLEWELYN, D., "Intellectual Property: Patents, Copyrights, Trade Marks and Allied Rights" (6th ed.) 707 (Sweet \& Maxwell, London 2007).

363 However, it was held in Case C-299/99 Philips v Remington (para. 49) that the EU law does not require that "the shape of the article in respect of which the sign is registered must include some capricious addition". 
jah" ${ }^{, 365}$ in relation to women clothing would obviously contravene both moral and public policy in the Christian community. Similarly, the use of Islamic name such as "Muhammad" as a Beer brand would unquestionably offend against the morality of people and public policy in the Muslim communities. In recent times the public policy principle acclaims strict adherence by trade mark practitioners and courts of law. In Phillips case, ${ }^{366}$ for instance, Attorney-General Ruiz-Jarabo opined that the word mark Babykiller for pharmaceutical products that are used for abortion was infringing on the accepted sentiments of right-thinking members of the society. Thus, justification for the exclusion from registration of signs that contravene the good morals of the society may be grounded on the fact that such signs "would cause offence to a section of the public" particularly where issues regarding sex, race, general matters of taste and decency or religious belief are reflected by a subject matter of trademark registration. ${ }^{367}$

There are some good reasons to exclude deceptive trade signs from registration: Since deceptive marks may claim the nature, quality or geographical origin which they do not have, consumers may be misled and turn to the goods or services marketed under the deceptive mark with a certain level of expectation based on their previous experience as far as the claimed nature, quality or geographical origin are concerned. ${ }^{368}$ Therefore, a deceptive mark is only concerned with the deceptiveness which is inherent in the sign itself. This is opposed to the deceptiveness which ensues in the relevant market where the use of similar or identical trade signs deceive (or rather, misleads) the consuming public.

Article 7(1) (h) and (i) of the CTMR outline some signs that cannot be registered as a CTM, unless a competent authority consents to the registration. While paragraph $(\mathrm{h})$ prohibits registration of state emblems, official hallmarks, and emblems of intergovernmental organisations within the meaning of Article $6^{\text {ter }}$ of the Paris Convention for the Protection of Industrial Property of 20 March 1883 as last revised at Stockholm on 14 July 1967 (hereinafter the Paris Convention) ${ }^{369}$; paragraph (i) protects symbols of public interest, ${ }^{370}$ other than

365 ISAACS, N., "Law of Trade Marks" 38 (CLT Professional Publishing, Birmingham 1996).

366 Phillips v. Remington [2001] E.T.M.R. 509, 516.

367 Cf. KITCHIN, D., et al, "Kerly's Law of Trade Marks and Trade names" (4th ed.) 212 (Sweet \& Maxwell, London 2005).

368 The OHIM's Board of Appeal found the sign "POLYblend" to be deceptive for "raw natural resins' as these materials could not be a mixture of polymers but the consumer may still think that the products which are marketed under the sign "POLYblend" were made of mixed polymers ( $c f$. OHIM, Case R-0924/2006-1).

369 Paragraph (1) of Article 6ter of the Paris Convention provides in part as follows:

"(a) The countries of the Union agree to refuse or to invalidate the registration, and to 
those already protected under paragraph (h), such as the Red Cross symbol. However, a cross containing some colour other than the red colour cannot be denied registration based on Article 7(1) (i), provided that words other than the "Red Cross" appear on it. ${ }^{371}$

A judgment of the CFI in Concept - Anlagen case ${ }^{372}$ expounds on the practical application of Article 7(1) (h). The appellant in the case sought to register a figurative mark which included a ring of twelve stars which made it look like the emblem of the European Union. Rejecting the application for registration, OHIM reasoned that since the EU emblem was reproduced in the mark applied for, "the impression that a mark sought designated a suborganisation of the European Union" was inevitable. ${ }^{373}$ As far as the emblems under Article $6^{\text {ter }}$ (a) and (b) of the Paris Convention are concerned, the prohibition does not apply if a registered trademark does not mislead the public as to the existence of connection between the user and the organisation. A decision by OHIM to allow registration of trademarks prohibited under Article 7(1) (h) and Article 7(1) (i) of the CTMR should analogically find justifications under Article $6^{\text {ter }}(1)(c)$ of the Paris Convention. Within the ambit of the second sentence of Article $6^{\text {ter }}(1)(\mathrm{c})$ :

$\ldots$ it is permissible, in the case of the emblem of an international organisation, to allow registration of a mark if it is not of such a nature as to suggest to the public that a connection exists between the organisation concerned and armorial bearings, flags, emblems, abbreviations and names or if such registration is probably not of such a nature as to mislead the public as to an existence of a connection between the user and the organisation. ${ }^{374}$

prohibit by appropriate measures the use, without authorisation by the competent authorities, either as trademarks or as elements of trademarks, of armorial bearings, flags, and other State emblems, of the countries of the Union, official signs and hallmarks indicating control and warranty adopted by them, and any imitation from a heraldic point of view. (b) The provisions of subparagraph (a), above, shall apply equally to armorial bearings, flags, other emblems, abbreviations, and names, of international intergovernmental organisations of which one or more countries of the Union are members, with the exception of armorial bearings, flags, other emblems, abbreviations, and names, that are already the subject of international agreements in force, intended to ensure their protection."

370 These symbols include badges, emblems or escutcheons which are of particular public interests ( $c f$. Article 7(1) (i) of the CTMR).

371 See OHIM's Board of Appeal decision in Case R 315/2006-1 (D\&W Repair) where a cross containing a different colour and the word "REPAIR" used in relation to spare parts was held not to contravene the Red Cross emblem.

372 CFI, 21 April 2004, Case T-127/02, Concept-Anlagen u. Geräte nach 'GMP' für Produktion u. Labor GmbH v. OHIM, not reported in the ECR.

373 See CFI, 21 April 2004, Case T-127/02, para. 6.

374 CFI, 21 April 2004, Case T-127/02, para 63. 
Literally interpreted, no sign can be registered within the ambit of Article 7(1) (j) of the CTMR, as a CTM for wines if such sign contains or consists of a geographical indication which tends to identify wines not having that origin. For this prohibition to apply, it is not necessary to prove that the use of false geographical indication is likely to mislead consumers. The only decisive factor is the falsehood implied in the relevant geographical indication.

\section{Acquired distinctiveness and public policy}

Article 7(3) of the CTMR stipulates that the absolute grounds against trademark registration provided for under paragraphs (b), (c) and (d) must not be observed where trade signs which were otherwise descriptive or generic acquire a secondary meaning, which when associated with the goods and services in respect of which registration of the signs in question is sought makes those signs distinctive. The question may thus arise as to whether the public interest enshrined in Article 7(1) of the CTMR is not observed under Article 7(3) ${ }^{375} \mathrm{~A}$ sound response would negate this question on two main grounds. Firstly, it is axiomatic that "a mark may be distinctive by nature or by "nurture". ${ }^{376}$ Similarly, distinctiveness of a trademark may be inherent or acquired. ${ }^{377}$ Secondly, acquired distinctiveness, otherwise known as secondary meaning, can only be appreciated after the mark has been used in the market.

The ECJ has once, in relation to acquired distinctiveness, opined that:

In determining whether a trade mark has acquired distinctive character following the use which has been made of it, the competent authority must make an overall assessment of the evidence that the mark has come to identify the product concerned as originating from a particular undertaking and thus to distinguish that product from goods of other undertakings. If the competent authority finds that a significant proportion of the relevant class of persons identify goods as originating from a particular undertaking because of the trade mark, it must hold the requirement for registering the mark to be satisfied. Where the competent authority has particular difficulty in assessing the distinctive character of a mark in respect of which registration is applied for, Community law does not preclude it

375 Jeremy Phillips posed, and addressed the same question: "what happens to "Need to Keep Free" in the Face of Conflicting Public Interests? It is not known what happens to the public interests in keeping a sign free once a sign that is barred from registration under "keep free" principles subsequently achieves registrability on the basis that it has acquired distinctiveness through use. Does it evaporate in the mists of time? Is it displaced by a higher public interest...?" (PHILLIPS, J., "Trade Mark Law and the Need to Keep Free", 36(4) IIC 389, 394 (2005).

376 FIRTH, A., et al, "Trade Marks - Law and Practice" (2nd ed.) 32 (Jordan Publishing, Ltd., Bristol 2005).

$377 C f$. Articles 7(1)(b) and 7(3) of the CTMR. 
from having recourse, under the conditions laid down by its own national law, to an opinion poll as guidance for its judgment. ${ }^{378}$

Distinctiveness that is ascertainable as above can be judged in light of several surrounding circumstances such as the goodwill a mark has given to the business in the relevant market. ${ }^{379}$ Thus, acquired distinctiveness is surely evidence that justifies the trademark protection regime which tries to avoid trademarks being dumped in the trademark register without the said mark being used in the marketplace. $^{380}$ It follows that Article 7(3) of the CTMR is designed to protect another category of public interest, namely prohibition against free riding the reputation of the mark developed in relation to particular goods or services. Reputation or goodwill of a mark does not emerge abruptly; it takes time for a person to create stronger business goodwill in the mind of the consuming public. Such process involves substantial investment in promotional activities for the said mark. ${ }^{381}$ It would be untenable to allow a third party to benefit from the goodwill in question, to which he has not made any contribution. Thus, the grant of a trademark monopoly on the basis of Article 7(3) (i.e. acquired distinctiveness) cannot be tantamount to the waiver of the public interests enshrined in Article 7(1) of the CTMR, but tends to define the scope of such interests. The public interest under Article 7(1)(b), for instance, applies as long as a particular sign lacks some concrete distinctiveness, while that under Article 7(1)(c) becomes relevant to a mark which is descriptive of goods or services. None of these two situations arises under Article 7(3). A mark to which the Article applies is distinctive and does not exclusively define the nature or quality of goods or services.

An important point regarding registrability of a sign as CTM under Article 7(3) looms high: acquired distinctiveness or secondary meaning, required for the

378 Cf. Joined cases C-108/97 and C-109/97, Windsurfing Chiemsee Produktions- und Vertriebs GmbH v. Boots- und Segelzubehor Walter Huber and Attenberger [1999]E.C.R. I-2799, operative part of the judgment. More on surveys and opinion polls as evidence of distinctiveness refer to NIEDERMANN, A., "Surveys as evidence inproceedings before OHIM", 37(3) IIC 260 et seq. (2006).

379 A sign acquires distinctiveness or secondary meaning when the consumers begin to believe that goods or services commercialized with the mark have one origin.

380 Inherent, as opposed to acquired, distinctiveness is the quality associated with the mark itself which makes it unique in the context of the goods or services it markets.

381 Such promotion may involve selling the products at loss, so that when the brand becomes stronger through acquired distinctiveness, the trademark proprietor may be able to recoup the business by selling at higher price. Incidentally, through extensive marketing and advertisement, the trademark proprietor teaches the relevant "consuming public that the sign, when used by him, is his way of demonstrating that goods or services bearing it originate with him" (cf. PHILLIPS, J., "Trade Mark Law and the Need to Keep Free", 36(4) IIC 389, 392 (2005). 
registration of a trade symbol which was otherwise devoid of distinctive character in some parts of the Community, must substantially be appreciated in those parts of the Community. This argument stems from the provisions of Article 7(2) of the CTMR, which bars registration of a sign as a CTM even where the mark lacks distinctiveness, or is generic, descriptive ${ }^{382}$ or customary in view of some circumstances obtaining only in a single part of the Community. While Article 7(2) incorporates the requirement that a registrable sign must possess distinctive character throughout the Community, the provisions in the Article enforce the "principle of unitary character" of the CTM. ${ }^{383}$

It is important to note that the provisions of Article 7(3) of the CTMR do not apply to shape marks. In view of the ECJ's decision in Benetton $/ G-S t a r$ " 384 'the shape of a product which gives substantial value to that product cannot constitute a trademark ${ }^{385}$ where, prior to the application for registration, it acquired attractiveness as a result of its recognition as a distinctive sign following advertising campaigns presenting the specific characteristics of the product in question".

To the extent that Article 15(1), second sentence of TRIPs, assumes that every medium is eligible for registration provided it is distinctive, the legal protection of three dimensional marks under the CTMR must be subjected to scrutiny. Whereas Article 4 of the CTMR already confirms that three dimensional shapes may be registered, such registration is only possible if these shapes are not specifically excluded from registration on the basis of absolute grounds under Article 7(1) (e) of the CTMR according to which signs resulting exclusively from the nature of the goods, which are necessary to obtain a technical result, or which give substantial value to the goods cannot be registered. Article 7(3) of the CTMR which permits registration of a sign based on a secondary meaning does not render the same result in respect of signs excluded from registration under Article 7(1) (e) of the CTMR. This position is a partial deviation from the

382 Where combination of words are, for instance, descriptive in one of the EU's languages used for trade in one of the Member States, such word combination are ineligible to be registered as a CTM ( $c f$. Article 7(2) and Case C-1112/99, Toshiba Europe GmbH v. Katun Germany GmbH [2001] ECR I-7945).

383 CFI, Case T-91/99, Ford Motor Company v. OHIM [2000] E.C.R. 1925, paras. 24 and 25.

384 ECJ, 20 September 2007, Case C-371/06, Benetton Group SpA v G-Star International $B V$ [2007] ECR I-07709, para. 28. The case concerns interpretation of Article 3(1) (e) of theTD, which is similar to Article 7(1) (e) of the CTMR. It was a reference made in the

course of the proceedings between the parties regarding the marketing by Benetton of an item of clothing which, by of its shape, infringes two shape marks registered by G-Star (cf. para. 2 of the judgment).

385 On the basis of acquired distinctiveness under Article 7(3) of the CTMR. 
provisions of second sentence of Article 15(1) of TRIPs whose literal import necessitates a conclusion that the shapes described under Article 7(1) (e) of the CTMR may be registered just upon meeting the distinctiveness test. The problematic aspect of those exceptions is that registration is not warranted even where the shapes referred to in Article 7(1) (e) of the CTMR acquire a secondary meaning. However, "[according] to the position adopted by the European Union, there is no conflict between this regulation [the CTMR] and the obligations under TRIPs, because shapes falling under the reservation clause cannot be regarded as "signs" in the meaning of the definition laid down in the first sentence of Article 15(1)". 386

It follows that the above position as adopted by the EU can only be justified under the public interests rather than the basic function of trademark; for "consumers are capable of recognizing the distinctive character of a product's shape", to the extent that they may even be confused as to the origin of two identically shaped products which bear different word marks. ${ }^{387}$

\section{Relative grounds for refusal}

Six types of relative grounds for refusal to register a CTM may be identified pursuant to Article 8(2) - (5) of the CTMR. These are: (1)earlier trademark registrations or applications, (2)earlier trademark registrations or applications with reputation, (3)earlier well-known marks, (4)agents' mark, (5)earlier unregistered trademarks, and (6)earlier signs used in the course of trade, except for signs with only local significance. ${ }^{388}$

According to Article 8(1) of the CTMR, relative grounds for trade mark refusal may be invoked by third parties to oppose registration of a CTM registration. ${ }^{389}$ Since the relative grounds for trademark refusal define the scope of a trademark monopoly, they are thus discussed in section $\mathrm{E}$ below in the context of CTM infringement.

386 KUR, A., "TRIPs and Trademark Law”, in: BEIER, F., \& SCHRICKER, G. (eds.), "From GATT to TRIPs - The Agreement on Trade-Related Aspects of Intellectual Property Rights" 100 IIC Studies Vol. 18 (VCH, Weinheim 1996).

387 PHILIPS, J., "Trade Mark Law: a Practical Anatomy" 143 (Oxford University Press, Oxford 2003).

388 Cf. also Rule 15(2) (b) of the CTMIR.

389 For the extensive discussion on opposition procedure and grounds for opposition $c f$. PAGENBERG, J., "Das Widerspruchsverfahren der Gemeinschaftsmarke - Neue Strategien im Markenrecht", 1998 GRUR 288. 


\section{E. CTM infringement}

Article 9 of the CTMR stipulates some circumstances under which CTM infringements may be presumed or proved. On the other hand, Article 8 of the CTMR strengthens the rights granted under Article 9 of the CTMR by allowing the right holder to prohibit registration of a sign the use of which would, but for registration, infringe his earlier rights. In order to determine whether a CTM has been, or is likely to be, infringed, various factors such as whether the use of a CTM by a third party falls within the scope of the exclusive rights that a CTM bestows upon the proprietor and the limitation posed against these rights have to be considered.

\section{Scope of CTM protection}

\section{Article 9 of the CTMR}

The scope of a CTM protection is systematically described under Article 9(1) (a), (b) and (c) of the CTMR.

According to Article 9(1) (a) of the CTMR, the CTM proprietor is entitled to interdict the use, in trade, by third parties, of any sign, which is identical to his trademark, where such use is in relation to goods or services, which are identical with those for which the proprietor's CTM was registered. A sign may be regarded as identical with a registered CTM if "it reproduces, without any modification or addition, all the elements constituting the trade mark or where, viewed as a whole, it contains differences so insignificant that they may go unnoticed by an average consumer". ${ }^{390}$ To put it simply, infringement under the paragraph will require the plaintiff to prove double identity, i.e. identity of the sign and the CTM as well as identity of goods or services marketed under the sign and the CTM. For a CTM proprietor to be able to prohibit the use of another sign within the ambit of Article 9(1) (a) of the CTMR, such a sign and the proprietor's mark must correspond in all aspects. If there is any difference between them, then the action must be decided under Article 9(1) (b). However, where an infringer reproduces in his sign a part of a registered CTM, he cannot be held liable under the double identity doctrine of infringement, notwithstand- 
ing the proof that the part which was reproduced in the infringing sign is "the most prominent part" of a CTM. ${ }^{391}$

A CTM proprietor enjoys some powers, pursuant to Article 9(1) (b) of the CTMR, to preclude third parties from using "any sign where, because of its identity with or similarity to the Community trade mark and the identity or similarity of the goods or services covered by the Community trade mark and the sign, there exists a likelihood of confusion on the part of the public". It follows that, ${ }^{392}$ where a CTM was registered to designate some goods, it may be infringed by an identical sign used in relation to similar goods, an identical sign used in relation to similar services, a similar sign in relation to similar goods, and a similar sign in relation to similar services. And, where registration of a CTM covers some services, infringing such a CTM would require an identical sign to be used for similar services, an identical sign to be used for similar goods, a similar sign to be used for identical goods, a similar sign to be used for similar services, and a similar sign to be used for similar goods. ${ }^{393}$

Article 9(1) (c) of the CTMR, empowers a CTM proprietor to prohibit third parties from using

... any sign which is identical with or similar to the Community trade mark in relation to goods or services which are not similar to those for which the Community trademark is registered, where the latter has a reputation in the Community and where use of that sign without the due cause takes unfair advantage of, or is detrimental to, the distinctive character or the repute of the Community trade mark.

Likelihood of confusion - a concept referred to in section E (II) of this chapter needs not be proven in order to substantiate trademark infringement claims brought under Article 9(1) (a) of the CTMR, since the law presumes existence of trademark confusion in every double identity cases. ${ }^{394}$ Given the special protection of a $\mathrm{CTM}^{395}$ enshrined under Article 9(1) (c) of the CTMR - a

391 Cf. PHILIPS, J., "Trade Mark Law: a Practical Anatomy” 314 (Oxford University Press, Oxford 2003).

392 Notwithstanding the language employed in Article 9(1) (b) of the CTMR, which does not lead to a clear, immediate understanding of the scope of the provision.

393 ANNAND, R. \& NORMAN, H., "Blackstone's Guide to the Community Trade Mark" 162 (Blackstone Press, London 1998).

394 Thus, liability for double identity cases (i.e. identical signs for identical goods) attaches strictly (ANNAND, R., \& NORMAN, H., "Blackstone's Guide to the Community Trade Mark" 162 (Blackstone Press, London 1998). The double identity cases are therefore helpful in particular in curbing "counterfeit or piracy cases" (KOOIJ, P.A.C.E. van der, "The Community Trade Mark Regulation: An Article by Article Guide" 33 (Sweet \& Maxwell, London 2000).

395 Article 9(1) (c) of the CTMR extends special protection to the CTM because it goes beyond the conventional trademark protection enshrined in the TRIPs Agreement. Article 16(1) of the Agreement limits trademark protection to the same scope of Article 
protection beyond the requirements of double identity or similarity as a yardstick for infringement - proof of likelihood of confusion is not required for the trademark infringement to be upheld. ${ }^{396}$ However, for an infringement to be upheld under the provisions of Article 9(1) (b) of the CTMR, the CTM proprietor must prove the likelihood of confusion in light of the likelihood of association. ${ }^{397}$

\section{Article 8 of the CTMR}

While the holder of rights stipulated under Article 8(2) (a) and (b) of the CTMR enjoys a right to prohibit unauthorised use of these rights based on Article 9(1) (a) and (b), he is as well allowed to interdict any attempt by third parties to register, as a CTM, any sign which is identical to or confusingly similar with these rights. The rights covered under Article 8 (2) (a) and (b) of the CTMR are earlier Community and national Trademark registrations as well as earlier Community and national trademark applications. ${ }^{398}$

The above analogy may as well be extended to Article 8(3) of the CTMR which regulates registration of a sign by an agent or representative of the right holder. Under the normal state of things an agent or a representative acts on behalf, and on the authority, of the principal. Thus, the use of the proprietor's mark by the agent or representative, in the course, and within the scope, of

9(1) (a) and (b) of the CTMR by stipulating that: "the owner of a registered trademark shall have the exclusive right to prevent all third parties not having the owner's consent from using in the course of identical or similar signs for goods or services which are identical or similar to those in respect of which the trademark is registered where such use would result in a likelihood of confusion. In case of the use of an identical sign for identical goods or services, a likelihood of confusion shall be presumed. The right described above shall not prejudice any existing prior rights, nor shall they affect the possibility of Members making rights available on the basis of use".

396 ECJ, 11 November 1997, Case C- 251/95, Sabel BV v. Puma AG [1997] ECR I-06191, paras. 20 and 21.

397 ECF, Case C-245/02, Anheuser-Busch Inc v Budějovický Budvar, OJ C 6, 8.1.2005, pp. 5 and 6 , para. 63.

398 While Article 8(2) (a) mentions the following earlier rights: (i) Community trade marks; (ii) trade marks registered in a Member State, or, in the case of Belgium, the Netherlands or Luxembourg, at the Benelux Trade Mark Office; (iii) trade marks registered under international arrangements which have effects in a Member State; (iv) trade marks registered under international arrangements which have effect in the Community, Article 8(2) (b) mentions applications for the trade marks referred to in Article 8(2) (2). However, only applications which mature to registration can entitle the applicant to object to registration of identical or similar signs. 
agency-principal relation, cannot amount to a CTM infringement under Article 9 of the CTMR. However, Article 8(3) of the CTMR foresees some activities by an agent which would be detrimental to the interests of the principal as far as trademark rights are concerned. Thus, pursuant to the immediately preceding Article, the agent will be acting outside the scope of his agency if, without proper authorisation, he seeks to register the principal's trademark. Hence, the principal is entitled to oppose an attempt by the agent to register the trademark. $^{399}$

This protection against the "disloyal agent or representative" that the proprietor of earlier CTM enjoys, under Article 8(3), is based on "a statusinherent obligation - which applies even without explicit agreement - to look after the business owner's interests" ${ }^{400}$ Such inherent obligation necessitates a conclusion that "without authorization, the agent should not be able to appropriate any right in a mark which the business owner previously claimed for himself and which typically is of no interest to the agent before he becomes the business owner's representative". ${ }^{401}$

Article 8(3) of the CTMR implements in part the provisions of Article $6^{\text {septies }}$ of the Paris Convention only to the extent the said provision in the Paris Convention gives the rightful owner the right to oppose registration of trademarks filed without his consent. The CTMR does not however provide for the business owner's right to recovery of damages. The express relief in this respect is available under Article 18 of the CTMR which provides that:

Where a Community trade mark is registered in the name of the agent or representative of a person who is the proprietor of the trade mark, without the proprietor's authorisation, the latter shall be entitled to demand the assignment in his favour of the said registration, unless such agent or representative justifies his action.

Article $8(5)$ of the CTMR strengthens protection of CTM or national trademarks with reputation. Thus, owners of these trademarks enjoy some right to exclude third parties, not only from using them, but also from having the said trademarks being registered in the third parties' names. Article 8(5) of the CTMR guarantees protection for trademarks with reputation even where the infringing sign is intended to be registered for goods which are not identical or similar to those for which the trademark with reputation is registered. Thus, Article 8(5) of the CTMR can be applied along with Article 9(1) (c) of the CTMR described above.

399 Corollary to this, the principal is entitled to prohibit the use of his mark by the agent pursuant to Article 11 of the CTMR.

400 INGERL, R., "Revised Regulation Governing Agents' Marks under the New German Trademark Act" 29(6) IIC 664, 665 (1998).

401 INGERL, R., "Revised Regulation Governing Agents' Marks under the New German Trademark Act" 29(6) IIC 664, 666 (1998). 
Hence, discussion on a trademark with reputation, in accordance with Article 9(1) (c) of the CTMR, addressed below under section 4.5.4 dealing with CTM with reputation, should be taken to refer to both Articles 9(1) (c) and 8(5).

Trademarks considered to be well-known in a Member State, within the meaning of Article 8(2) (c) of the CTMR, are distinguishable from trademarks with reputation under Articles 8(5) and 9(1) (c) of the CTMR. According to Article 8(2) (c) of the CTMR, an earlier but well-known mark ${ }^{402}$ within the prescription set out in Article $6^{\text {bis }}$ of the Paris Convention ${ }^{403}$ entitles its proprietor to oppose a similar mark. ${ }^{404}$ The only decisive factor is whether the respective trade mark is well known in the country where protection is sought or in a substantial part of $i^{405}$ and that the infringing mark is used for goods or services similar with those covered by the well-known mark. ${ }^{406}$ Coca-cola and Puma or BMW trademarks for instance, may be mentioned as examples of well-known trademarks.

402 Article 8(2) (c) of the CTMR defines earlier but well known trademarks as "trade marks, which on the date of application for registration of the Community trade mark, or where appropriate, of the priority claimed in respect of the application for registration of the Community trade mark, are well known in a Member State, in the sense in which the words 'well known' are used in Article 6bis of the Paris Convention."

403 Article 6bis(1) of the Paris Convention provides that "the countries of the Union undertake, ex officio if their legislation so permits, or at the request of an interested party, to refuse or to cancel the registration, and to prohibit the use, of a trademark which constitutes a reproduction, an imitation, or a translation, liable to create confusion, of a mark considered by the competent authority of the country of registration or use to bewell known in that country as being already the mark of a person entitled to the benefits of this Convention and used for identical or similar goods. These provisions shall also apply when the essential part of the mark constitutes a reproduction of any such well-known mark or an imitation liable to create confusion therewith".

404 Paragraphs 2 and 3 of Article 16 of TRIPs strengthens protection of well-known marks by stipulating that: " 2 . Article 6 bis of the Paris Convention (1967) shall apply, mutatis mutandis, to services. In determining whether a trademark is well known, Members shall take account of the knowledge of the trademark in the relevant sector of the public, including knowledge in the Member State concerned which has been obtained as a result of the promotion of the trademark. 3. Article 6bis of the Paris Convention (1967) shall apply, mutatis mutandis, to goods or services which are not similar to those in respect of which a trademark is registered, provided that use of that trademark in relation to thosegoods or services would indicate a connection between those goods or services and the owner of the registered trademark and provided that the interests of the owner of the registered trademark are likely to be damaged by such use".

405 ECJ, 22 November 2007, Case C-328/06, Alfredo Nieto Nuño v Leonci Monlleó Franquet [2007] ECR I-10093, para. 21.

406 However, Article 16(3) of the TRIPS Agreement requires a well-known mark to be registered in order to be protected against an infringing mark used for dissimilar goods or services. 
Unregistered trademarks or other signs such as company names, trade names, business signs, titles of protected literally or artistic works and the right to a sign under passing-off are all together regarded as 'unregistered and earlier signs used in trade'. ${ }^{407}$ These rights entitle the owner to register a similar mark. Consequently, the owner may, based on his unregistered and earlier signs used in trade, oppose any attempt by third parties to register a CTM which is similar to the earlier rights. However, the earlier rights protected under Article 8(4) of the CTMR are not mentioned in Article 42(2) and (3) of the CTMR in connection with the requirement of proof of use. Since enforceability of the earlier rights is contingent upon their use, evidence regarding the "use must be submitted in the reasoning of the opposition in the form that can be verified". 408

The earlier rights protected under Article 8(4) of CTMR must be of more than mere local significance. Although there is hitherto no ECJ's decision clarifying the phrase "rights of more than mere local significance", it may be assumed that, in view of analogous ECJ's decisions, ${ }^{409}$ the earlier rights concerned will fulfil the requirements of the quoted phrase if they are known by a big section of the people. One may thus question as to what happens when the earlier rights concerned are of local significance. The response to this query depends on the national law under which the rights concerned are protected. Unless the respective national law prohibits, the earlier rights of a mere local significance will, pursuant to Article 111(1) of the CTMR, entitle the proprietor to prohibit the use of a similar CTM in the territory where the said earlier rights enjoy protection. $^{410}$

These rights should predate the date of application for registration of a future CTM and the priority date which the application for registration of junior CTM claims.

407 “Opposition Guidelines" (Part 1), 16 (OHIM 2007).

408 PAGENBERG, J., "Opposition Proceedings for the Community Trademark - New Strategies in Trademark Law" 29(4) IIC 406, 409 (1998).

$409 C f$. for instance, Case C-375/97, General Motors Corporation v Yplon SA [1999] ECR I05421 (paras. 26, 28 and 31), which implies that an earlier right could be of more mere local significance if it is known by a significant number of people in just a part of one of the EU countries.

410 Different points, which are relevant to the earlier rights of a mere local significance and, which may be debated here, are reserved for the discussion in Chapter 5 infra in relation to the interface between CTM and national trademark rights. 


\section{Likelihood of confusion}

Likelihood of confusion is central for determining whether some use made of a particular sign by a third party is within the scope of the exclusive rights, of the CTM registrant, described under Article 9(1) (b) of the CTMR. ${ }^{411}$ The concept "likelihood of confusion" is given statutory recognition under Articles 8(1) (b) and 9(1) (b) of the CTMR. ${ }^{412}$ It must, however, be made clear at the outset that while likelihood of confusion serves as a relative ground for trademark refusal, it is also a condition for finding trademark infringement under Article 9(1) (b) of the CTMR as it constitutes the specific condition for the protection afforded by a CTM. ${ }^{413}$ This implies that the meaning ascribed to the phrase "likelihood of confusion" in course of CTM infringement proceedings does not differ from the way OHIM interprets the phrase, as a relative ground for a CTM refusal, during trade mark examination or opposition proceedings. ${ }^{414}$ Indeed, this approach cannot be questioned, since a CTM proprietor has right under both Articles 9(1) (b) and 8(1) (b) of the CTMR respectively to prevent anyone from using his mark, or anyone else applying to register a trademark the use of which could be prevented in view of the essential function of a trademark. ${ }^{415}$

\section{CTM function and likelihood of confusion}

Registration of a CTM guarantees that wherever such a mark is used, it will be used as an indication of origin. ${ }^{416}$ This conclusion is supported by various decisions of the $\mathrm{ECJ},{ }^{417}$ which altogether confirm that:

411 ECJ, 11 November 1997, Case C- 251/95, Sabel BV v. Puma AG [1997] ECR I-06191, para. 22. $C f$. also HIDAKA, S., et al, "A sign of the times? A review of key trade mark decisions of the European Court of Justice and their impact upon national trade mark jurisprudence in the EU", 94(5) TMR 1105, 1129 (2004).

412 Article 8(1) (b) of the CTMR stipulates that: "upon opposition by the proprietor of an earlier trade mark, the trademark applied for shall not be registered if because of its identity with or similarity to the earlier trademark and identity or similarity of the goods or services covered by the trade marks there exists a likelihood of confusion on the part of the public in the territory in which the earlier trade mark is protected; likelihood of confusion includes the likelihood of association with the earlier trade mark". Article 9(1)

(b) is reproduced in section E (I) (1) of this chapter.

$413 C f$. recital 8 of the CTMR.

414 Cf. "Opposition Guidelines" (Part 2 Chapter 2A) 3 (OHIM 2004).

415 The phrase "essential function of a trade mark" is elucidated in chapter 6 infra.

$416 C f$. recital 8 of the CTMR.

417 Cf. Case C-120/04, Medion AG [2005] ECR I-08551, para. 23; Case C-371/02, Björnekulla Fruchtindustrier [2004] ECR I-05791, para. 20 and Case 39/97, Canon 
The essential function of the trade mark is to guarantee the identity of the origin of the marked product to the consumer or end user by enabling him, without any possibility of confusion, to distinguish the product or service from others which have another origin. For the trade mark to be able to fulfil its essential role in the system of undistorted competition, it must offer a guarantee that all the goods or services bearing it have originated under the control of a single undertaking which is responsible for their quality. ${ }^{418}$

Such a guarantee is diminished where the use of a sign by another - not authorised by the CTM proprietor - carries with it the risk that the public might believe that the goods and services marketed under the sign and those marketed under the CTM come from the same or economically linked companies, for such use would constitute a likelihood of confusion. The same holds true even where the public is of the view that the goods or services do not originate from the same entity stricto sensu, but only from economically linked undertakings, as there could still be a risk of confusion in this scenario too. ${ }^{419}$ The controlling requirement here is the likelihood that the public believes that a single entity is responsible for the goods or services. ${ }^{420}$ It can generally be assumed that, "there can be no such likelihood of confusion where it does not appear that the public could believe that the goods and services come from the same undertaking or, as the case may be, from economically-linked undertakings". ${ }^{421}$ However, trademark infringement might also be upheld even where the use of an infringing sign does not interfere with the trademark's function at the point of sale, but does so after the sale. Post sale confusion ensues where "those who are confronted with the goods after they have left the infringer's point of sale, are likely to interpret the sign, as it is used by the infringer, as designating or tending to designate the undertaking from which the infringer's goods originate". ${ }^{422}$

[1998] ECR I-05507, para. 28.

418 Cf. Case C-10/89, HAG GF (HAG II) [1990] ECR I-3711, paras. 13 and 14.

419 This view is in line with a distinction between direct and indirect risks of confusion drawn by the ECJ in the following words: "there is a risk of confusion between two trade marks not only when the public might mistakenly assume that the goods concerned come from one and the same undertaking (direct risk of confusion) but also when the mistaken assumption relates to the existence of an organizational or economic link between the undertakings concerned, such as licensing agreement under which one undertaking is authorized to manufacture a product with the same properties as the product of the other (risk of confusion in the broadest sense)" ( $c f$. Case C-317/91 Deutsche Renault AG v AUDI AG [1993] ECR I-06227, para. 36).

420 Cf. "Opposition Guidelines" (Part 2 Chapter 2A) 7 (OHIM 2004).

421 Case C-39/97, Canon Kabushiki Kaisha [1998] ECR I-05507, para. 30.

422 ECF, Case C-245/02, Anheuser-Busch Inc v Budějovický Budvar, OJ C 6, 8.1.2005, p. 5- 6, para. 60 . 
Since the risk of confusion is eminent "when there is a likelihood that the public might believe that the goods or services in question come from the same undertaking, or as the case may be, from economically-linked undertakings", ${ }^{423}$ an assessment of the likelihood of confusion is therefore done in accordance with how the relevant public perceives the signs in relation to products or services in issue. Such an assessment takes into account all circumstantial factors relevant to each case, namely, the interdependence between the similarity of the signs and the similarity of the goods or services. ${ }^{424}$ Confusion is further assessed on the basis of how an average consumer ${ }^{425}$ would behave given two or more products of different origin but using identical or confusingly similar marks. It must be conceded that an average consumer perceives a mark as a whole and does not proceed to analyse its various details although he may break it down into word elements which, for him, suggest a concrete meaning or which resemble words known to him. ${ }^{426}$ The average consumer is presumed to be reasonable, fully informed, observant and circumspect. ${ }^{427}$

However, the level of attention that the ideal consumer pays varies depending on the type of goods or services concerned. ${ }^{428}$ If the goods in question are everyday consumer goods, the consumer involved here would not be adjudged as unreasonable or uninformed or not circumspect merely because he has mistakenly turned to some fake products assuming the same to be the ones, he usually purchases under the mark accustomed to him. Since such a consumer has some preconceived knowledge about the characteristics of the goods, he is accustomed

423 CIF, 6 May 2008, Case T-246/06 Redcats SA v OHIM, [2008] ECR II-00071, para. 29.

424 CFI, 11 July 2007, Case T-150/04, Mülhens GmbH \& Co. KG v OHIM [2007] ECR II02353 , para. 26.

425 The word " "consumer' is to be understood in the wide sense of the term, and should not be restricted to those persons who actually and physically consume the product. In that respect, reference can be made to the term 'consumer protection' which covers all parts of the consuming public. Because of the nature of the goods or services to which a mark is applied can vary considerably, actual and/or potential consumers can be different in each case. Groups of actual and/or potential consumers may be identified with the help of parameters such as the target group for the goods and services in relation to which the mark is used or the group of actual purchasers" ( $c f$. "Opposition Guidelines" (Part 2 Chapter 2A) 14 (OHIM 2004).

426 CFI, 27 February 2008, Case T-325/04, Citigroup, Inc. v OHIM [2008] ECR II-00029, para. 78 .

427 CIF, 6 May 2008, Case T-246/06, Redcats SA v OHIM [2008] ECR II-00071, para. 30.

428 CFI, 15 January 2008, Case T-9/05, Hoya Kabushiki Kaisha v OHIM [2008] ECR II00003 , para. 29. 
to; he is likely not to notice a slight dissimilarity between the infringing sign and the CTM.

In contrast, the result would not be the same as above where the products to which the infringing sign and a CTM are applied, though same or similar, are intended for consumption by a specific class of people who have a specialised knowledge regarding the products in connection with which the sign and the CTM are used. This may particularly be the case where the products concerned are some raw materials such as unprocessed plastics out of which the specialists who are engaged in further processing of the materials would manufacture semiprocessed plastics and plastic substances. ${ }^{429}$ Since these raw materials are not in common use, the specialists concerned (i.e. the average consumers) are reasonably expected to demonstrate a sufficient attentiveness when choosing the products. $^{430}$

Suppose the goods at issue are, antitussive medicines, food supplements and vitamin preparations, the relevant public would definitely comprise of a consumer, who, even where presumed attentive and informed about the characteristics of the pharmaceutical and nutraceutical products, which he purchases in order to improve his health, it would still be extremely difficulty (due to the often foreign and scientific sounding names of these products) for him (as non-specialised person) to remember them correctly. ${ }^{431}$ However, this scenario can be distinguished from the cases involving some very expensive products such as furniture. Under the latter, "the process of comparison and reflection before the choice is made" requires a higher level of attention. An average consumer does not regularly buy such expensive items and hence he is expected to be cautious by maintaining a higher level of attentiveness (than his normal level of attention) when purchasing those goods. ${ }^{432}$

Thus, a higher level of attention will be imputed to the consumer in every case concerning expensive, infrequent or risky purchases. ${ }^{433}$

429 CFI, 17 April 2008, Case T-389/03, Dainichiseika Colour \& Chemicals Mfg. Co. Ltd. V OHIM, [2008] ECR II-00058, paras. 57 to 59.

430 CFI, 17 April 2008, Case T-389/03, Dainichiseika Colour \& Chemicals Mfg. Co. Ltd. V OHIM [2008] ECR II-00058, para. 100.

431 See the decision of the second Board of Appeal (OHIM), 30 April 2008, Case R 1630/2006-2, Matthias Rath v Portela \& Ca., S.A., para. 59.

432 CFI, 16 January 2008, Case T-112/06, Inter-Ikea Systems BV v OHIM [2008] ECR II00006, para. 37.

433 "Opposition Guidelines" (Part 2, Chapter 2D) 11 (OHIM 2007). 


\section{Thresholds of likelihood of confusion}

For a CTM infringement to be affirmed under Articles 9(1) (b) and 8(1) (b) of the CTMR, likelihood of confusion will not be presumed, as the case would be where the goods and services as well as the conflicting signs were identical, but must be proved. ${ }^{434}$ As the ECJ has held repeatedly, "even where a mark is identical to another with a highly distinctive character, it is still necessary to adduce evidence of similarity between the goods or services covered", since "the likelihood of confusion presupposes that the goods or services covered are identical or similar". ${ }^{435}$ Likelihood of confusion is thus appreciated globally by taking account of several factors including, but not limited to, "the degree of similarity between the signs and the goods or services". ${ }^{436}$

\section{a) Similarity of trademarks}

In order to determine whether there is a likelihood of confusion the conflicting marks have to be compared in terms of their visual, aural and conceptual similarity. ${ }^{437}$ The distinctive and dominant components of the signs in question may be taken into account to determine the overall impression of such similarity.

\section{aa) Visual similarity}

As regards the visual comparison between the opposing signs, the visual similarity of the dominant elements of the earlier trademark is a decisive factor in founding the likelihood of confusion. In a case involving LES PAGES JAUNES (as a CTM) and PAGESJAUNES.COM (as an infringing sign); the expression "pages jaunes" could constitute a dominant element of the CTM and the sign. Hence, the dominant element makes the sign and the mark visually

434 However, an argument that likelihood of confusion must not be proven in relation to confusingly similar marks may be accentuated: Since from etymological point of view the term "likelihood of confusion" may be treated as a risk or a danger of confusion, actual confusion is not a condition for affirming a likelihood of confusion, even though evidence of actual confusion would favour a finding of a likelihood of confusion ( $c f$. "Opposition Guidelines" (Part 2, Chapter 2D) 17 (OHIM 2007).

435 Case C-39/97, Canon Kabushiki Kaisha [1998] ECR I-05507, para. 22.

436 ECJ, 11 November 1997, Case C- 251/95, Sabel BV v. Puma AG [1997] ECR I-06191, para. 22.

437 ECJ, 12 June 2007, Case C-334/05 P, OHIMv Shaker di L. Laudato \& C. Sas [2007] I04529 , para. 35. 
similar, notwithstanding the fact that the CTM comprises of "three words with a total of five syllables" in contrast to the infringing sign, which consists of one word of six syllables. ${ }^{438}$ It follows that a finding of a likelihood of confusion based on visual similarity cannot be overruled on the ground that the dominant word element included in the infringing sign (such as "pages jaunes") is a nondistinctive or is a generic term forming part of the CTM. In this regard, it has been held that "even in a case involving an earlier mark of weak distinctive character, there may be a likelihood of confusion on account, in particular, of a similarity between the signs and between the goods or services covered" ${ }^{439}$ This is because a weak distinctive character of an element of a complex mark may make an impression on consumers and be remembered by them. ${ }^{440}$ However, where a visually descriptive, dominant element (common to both the CTM and an infringing sign) leads to a finding of likelihood of confusion, such a finding cannot, by itself, confer on the CTM proprietor some exclusive rights on the use of such a dominant element. This could also be the case, for instance, where LINK (as a CTM) and WORLDLINK (as an infringing sign) are the subject of a dispute. In this scenario the word LINK would be held to be a dominant, visual element notwithstanding the fact that the term LINK lacks sufficient distinctiveness for "banking services for the dispensing of cash; fund transfer and payment services; financial services" ${ }^{441}$ Nevertheless, the court would not hesitate to uphold the likelihood of confusion between the infringing sign and the CTM, while leaving open the possibility of other proprietors to use the term LINK in relation to future trademark or applications. ${ }^{42}$

In assessing visual similarity, the figurative elements of a CTM used along with a word element are often considered to be marginal, especially where such word elements are predominantly similar to the infringing sign. Suppose that "amply" (a CTM) and "amplitude" (an infringing sign) are in issue. Assume further that the CTM is composed of some figurative elements of ordinary turquoise-blue printed letter. These elements cannot be considered dominant

438 Cf. CFI, 13 December 2007, Case T- 134/06, Xentral LLC v OHIM [2007] ECR II05213, paras. 53, 57 and 58 .

439 Case T- 134/06, Xentral LLC v OHIM [2007] ECR II-05213, para. 70.

440 Case T- 134/06, Xentral LLC v OHIM [2007] ECR II-05213, para. 54.

441 CFI, 27 February 2008, Case T-325/04, Citigroup, Inc. v OHIM [2008] ECR II-00029, para. 67.

442 CFI, 27 February 2008, Case T-325/04, Citigroup, Inc. v OHIM [2008] ECR II-00029, para. 98 . 
features of the CTM apart from the word "amply" itself, since the CTM is, with the exception of a single letter (y instead of i) included in the infringing sign. ${ }^{443}$

The CFI's jurisprudence reveals that the verbal element will not always be automatically considered where a mark in question consists of both verbal elements and figurative elements. This is due to the reasoning that in a complex mark the figurative elements may occupy a position equivalent to the verbal element. In Inter-Ikea Systems BV, the court considered the figurative elements of the contested mark ${ }^{444}$ and found that those elements possessed a relatively high degree of intrinsic distinctiveness due to the "small squares regularly aligned to evoke a sense of order or modularity". ${ }^{445}$ Thus, a distinctive figurative trademark cannot be held to be visually similar to earlier word mark on the ground that the trademark applied for uses in its figurative element the term which is visually similar to that used in the earlier mark.

bb) Aural or phonetic similarity

Pronunciation of the word elements of the opposing signs may determine the extent of the likelihood of confusion. In Quelle $\mathrm{AG}^{446}$ the earlier figurative national mark which had a word element MARS and the trademark NARS (the Community trademark applied for) were in dispute. Assessing aural similarity, the court found that the letters a, r, and s were phonetically common to the word elements of NARS and MARS. In spite of the fact that consumers usually attach more weight to the first part of the word, the phonetic difference to the first letters of the signs in question could not reverse a finding of aural similarity. Thus, minor phonetic difference does not "counteract the similarity arising from the identity between the most significant parts, in terms of number of letters, of the conflicting signs". 447

443 CFI, 15 January 2008, Case T-9/05, Hoya Kabushiki Kaisha v OHIM [2008] ECR II00003 , paras. 36 to 41 .

444 Whereas the sole element of the earlier mark was the term "ikea"; the contested mark was a complex mark composed of the verbal element "idea" and a figurative element. Such figurative element took the form of a grid with rounded corners made up of 15 small squares: 14 white squares and one black square, presented diagonally in the upper left corner.

445 CFI, 16 January 2008, Case T- 112/06, Inter-Ikea Systems BV v OHIM [2008] ECR II00006 , paras. 44 to 61 .

446 CFI, 8 February 2007, Case T-88/05, Quelle AG v OHIM [2007] ECR II-00008.

447 CFI, 8 February 2007, Case T-88/05, Quelle AG v OHIM [2007] ECR II-00008, para. 63. 
The CFI's judgment dealing with the marks AMPLITUDE/Amply ${ }^{448}$ stresses that visually dissimilar syllables may be phonetically similar when used in different languages. Thus, the court found that the first two syllables of the marks in question created phonetically similar impression due to the fact that "in Spanish, the letters ' $y$ ' and ' $i$ ' are both pronounced like the vowel 'i'". Despite the fact that consumers were likely to reinforce in their minds such phonetic similarity, the addition of syllables 'TUDE' doubled the length of the mark applied for and thus weakening the phonetic similarity. ${ }^{449}$ Diminishing the likelihood of confusion on phonetic similarity basis, the court held that, "in Spanish, the main stress, in respect of the two marks at issue, is on the penulti-mate syllable". Accordingly, in the word element amply, the main stress is on the syllable 'am' and, in the word element amplitude, the main stress is on the syllable 'tu'. Since "in Spanish, the stressed syllable 'tu' in the mark applied for" (is one of the syllables added to the common root of the conflicting marks, and) "is longer than the stressed syllable 'am' in the earlier mark", the court ruled in favour of phonetic difference. ${ }^{450}$

Where the conflicting marks consist of the same number of letters and contain the same sequence of vowels, the court may rely on the sound of a consonant in the marks to determine the phonetic similarity or difference of the marks. ${ }^{451}$ Thus, the consonants $d$ and $k$ in the idealikea marks were held to be different because the former is voiced epical consonant and the latter is a voiceless dorsal consonant. Consequently, there is no aural similarity between the marks concerned unless such marks contain in their word elements an "identical sequence of at most three matching sounds". ${ }^{452}$

Phonetic comparison "must be made with regard to all the languages spoken by the relevant public" ${ }^{453}$, i.e. all EC languages, "and not with regard only to

448 CFI, 15 January 2008, Case T-9/05, Hoya Kabushiki Kaisha v OHIM [2008] ECR II00003.

449 CFI, 15 January 2008, Case T-9/05, Hoya Kabushiki Kaisha v OHIM [2008] ECR II00003, paras. 42 to 44 .

450 CFI, 15 January 2008, Case T-9/05, Hoya Kabushiki Kaisha v OHIM [2008] ECR II00003 , para. 46.

451 CFI, 16 January 2008, Case T- 112/06, Inter-Ikea Systems BV v OHIM [2008] ECR II00006, para. 64.

452 CFI, 16 January 2008, Case T- 112/06, Inter-Ikea Systems BV v OHIM [2008] ECR II00006, para. 66.

453 Since "the protection afforded to the earlier mark covers the whole Community; what must be considered is the perception which the consumer of the goods at issue has of the marks at issue within the whole of that territory". Cf. CIF, 6 May 2008, Case T-246/06, Redcats SA v OHIM [2008] ECR II-00071, para. 31. 
French and English". ${ }^{454}$ International character of the market intended for the goods bearing the conflicting marks may also play a decisive role (as to which language is applicable) as far as aural similarity in relation to the likelihood of confusion is concerned. In GAVALLIA/GALVALLOY case, ${ }^{455}$ the OHIM's board of appeal based only on French rules of pronunciations to determine phonetic similarity of the two opposing marks. However, on appeal, the CFI found the two marks to be aurally similar on the basis of English pronunciation. The court reasoned that since the marks were intended to be used in the steel industry, the market in that industry was highly internationalised to the extent that only English was the corresponding consumer language in such market. ${ }^{456}$

It is important to note that "the degree of phonetic similarity between two marks is of less importance in the case of goods which are marketed in such a way that, when making a purchase, the relevant public perceives visually the mark" by which those goods are designated. ${ }^{457}$ Hence, an assessment of conceptual similarity comes into play to determine the intersection of the phonetic (or aural) and visual similarity.

\section{cc) Conceptual similarity}

Conceptual similarity between the sign and the CTM is assessed in the light of the impression which such marks call to the relevant consumer's mind. In a scenario involving PAGESJAUNES.COM (as an infringing sign) and LES PAGES JAUNES (as a CTM), confusion would be discerned on the basis of conceptual similarity. This finding would not be reversed by the fact that the CTM, by using LES at the beginning, differs from the infringing sign, which uses .COM at the end. Thus, comparison of the sign and the CTM may indicate that they both refer to yellow (pages) or paper-based directories, notwithstanding the ending of .COM to the infringing sign for such an ending does not alter the meaning of the expression PAGES JAUNES (which is dominant element to both

454 CIF, 6 May 2008, Case T-246/06, Redcats SA v OHIM [2008] ECR II-00071, para. 45.

455 CFI, 14 February 2008, Case T-189/05, Usinor SA v OHIM [2008] ECR II-00022, paras. 58 to 61 .

456 According to the court, the relevant public were French speaking consumers with knowledge of English language ( $c f$. Case T-189/05, Usinor SA v OHIM [2008] ECR II00022, paras. 59 and 65).

457 Cf. CFI, 8 February 2007, Case T-88/05, Quelle AG v OHIM [2007] ECR II-00008, Para. 69. 
marks) but merely suggests that the goods marketed under the infringing sign can be "consulted or bought over the internet". ${ }^{45}$

In order to conceptualise a mark consisting of a prefix and suffix, a relevant consumer will normally perceive such mark as a whole without resorting to a rigorous analysis of its various details. He may, nevertheless, perceive such a verbal sign by breaking it down "into verbal elements which, for him, suggest a concrete meaning or which resemble words known to him". 459 Thus, in GALVALLOY/GALVALLIA case, the court having determined that the relevant public was the French speaking with the knowledge of English language, concluded that such public would, in the mark applied for, "recognise the presence of the English word 'alloy', corresponding to 'alliage' in French, even if the first letter of that word 'a' has merged with the last letter of the prefix 'galva', according to the usual process of haplology". "460 Moreover, "the evocative force of the suffix "allia"" in the earlier mark could trigger a perception in the mind of the relevant public that the suffix referred to the word 'alliage'. Consequently, the possible interpretation, by the public would be that, "both signs referred to the concepts of galvanisation and alloy" and hence, (the opposing marks are) conceptually similar. ${ }^{461}$

Determination of the conceptual similarity is only possible where both the opposing marks contain word elements capable of semantic meaning; for "there can be no conceptual similarity between a mark which conveys no clear meaning in any of the official languages of the European Union" and another mark whose verbal element carries some actual meaning in the minds of the EC public. ${ }^{462}$ Thus, where the mark applied for (or the infringing sign) contains a word (such as idea) which has a real meaning for the European public, cannot be held conceptually similar to an earlier trademark containing neologism such as ikea. ${ }^{463}$

Moreover, grammatical rules are taken into account to justify conceptual similarity (and/or dissimilarity). In WORLDLINK/LINK case, the CFI had to

458 CFI, 13 December 2007, Case T- 134/06, Xentral LLC v OHIM [2007] ECR II-05213, para. 62 .

459 CFI, 14 February 2008, Case T-189/05, Usinor SA v OHIM [2008] ECR II-00022, para. 62.

460 CFI, 14 February 2008, Case T-189/05, Usinor SA v OHIM [2008] ECR II-00022, para. 65.

461 CFI, 14 February 2008, Case T-189/05, Usinor SA v OHIM [2008] ECR II-00022, paras. 66 to 68 .

462 CFI, 16 January 2008, Case T- 112/06, Inter-Ikea Systems BV v OHIM [2008] ECR II00006, para. 70 .

463 CFI, 16 January 2008, Case T- 112/06, Inter-Ikea Systems BV v OHIM [2008] ECR II00006 , para. 71. 
resort to the rules of English grammar and found that the element 'world' (in the trademark applied for) would be perceived by all consumers in the United Kingdom, "(on account of its position at the beginning) as an adjective meaning 'global' and qualifying the element 'link" with the consequence that the conceptual importance of the word element 'world' would be less if compared with the word element 'link'. ${ }^{464}$ Conceptually, therefore, the earlier mark link would literally be understood in its natural semantic meaning, whereas the mark applied for worldlink would be perceived by the relevant public as meaning 'global link'. Thus, the marks in question are conceptually similar for they are based on the same concept (link) only being distinguished by the addition of geographical qualifier (world).

\section{b) Similarity of goods and/or services}

Similarity between goods or services covered by the opposing marks may convey perception in the minds of consumers that the goods or services have the same origin or are marketed under one trademark. The provisions of Articles 8(1) (b) and 9(1) (b) of the CTMR presuppose that likelihood of confusion will mainly base on the identity or similarity between goods and services covered by the opposing marks. Even where the mark applied for (or the infringing sign) is obviously identical (in terms of aural, visual and conceptual similarity) to a particularly distinctive $\mathrm{CTM}^{465}$ it is still a condition to furnish evidence regarding the similarity between the goods or services covered by the opposing trademarks. ${ }^{466}$ It means therefore that slight similarity of the goods or services can be complemented by the high degree of similarity of the signs and vice versa. ${ }^{467}$

The practice obtaining in some European jurisdictions ${ }^{468}$ in relation to the assessment of similarity of goods or services takes into consideration various factors, namely uses of the goods or services; users or consumers of the goods or

464 CFI, 27 February 2008, Case T-325/04 Citigroup, Inc. v OHIM [2008] ECR II-00029, para. 82.

465 The distinctive character of an earlier trademark is taken into account "not in order to assess similarity of the goods, but in order to assess whether there is a likelihood of confusion" ( $c f$. CFI, 12 June 2007, Case T-105/05, Assembled Investments (Proprietary) Ltd v OHIM [2007] ECR II-00060, para. 29).

466 CFI, 11 July 2007, Case T-150/04, Mülhens GmbH \& Co. KG v OHIM [2007] ECR II02353, para. 27.

467 CFI, 11 July 2007, Case T-443/05, El Corte Ingles SA v OHIM, para. 40.

468 Jurisdictions such as the United Kingdom ( $c f$. FIRTH, A., et al, "Trade Marks - Law and Practice" (2nd ed.) 80 (Jordan Publishing, Ltd., Bristol 2005). 
services; physical nature of the goods or acts of service; channels through which the goods or services reach the market; nature of the shops where goods are sold (whether the goods are sold in the super markets, in particular whether they are shelved close to each other and the impact the self-service practice of the supermarkets will have on the consumer's confusion); and the extent to which the goods are in competition with each other. ${ }^{469}$

It is, thus, clear that likelihood of confusion on the grounds of similarity between the goods or services is assessed by taking into consideration "all the relevant factors which characterise the relationship between" the goods or services such as "their nature, their intended purpose and their method of use and whether they are in competition with each other or are complementary." ${ }^{470}$ Other factors such as distribution channels and business outlets may also be taken into account. ${ }^{471}$

The dictum stated in paragraph 109 in Koipe Corporación SL judgment ${ }^{472}$ reiterates the fact that distribution channels may enhance the level of consumer confusion where the opposing marks consist of similar or closely similar figurative elements. Basing on the fact that "olive oil is most commonly purchased in supermarkets", and given the fact that both CARBONELL (earlier mark) and la española (the mark applied for) use similar figurative elements and are applied to fat-related products, the court upheld the Board of Appeal's findings of similarity between the goods marketed under the opposing marks. The court was of the considered view that in supermarkets, "the consumer is guided by impression than by a direct comparison of the various marks". Consequently, in supermarkets the consumer normally examines the marks speedily and at the distance. In such circumstances and given the fact that an average consumer perceives a mark as a whole due to the wants of an analysis as to the mark's various details, the "differences between the signs at issue are more difficult to distinguish and the similarities are more apparent".

In Assembled Investments (Proprietary) $\mathrm{Ltd}^{473}$ the articles of glassware and the wine were held to be different in terms of their nature and purpose of use

469 Alison Firth mentions these factors and points out that the factors were cited in Canon Kabushiki Kaisha v Metro Goldwyn Mayer Inc (Case 39/94, [1999] ETMR 1) (cf. FIRTH, A., et al, "Trade Marks - Law and Practice" (2nd ed.) 80 (Jordan Publishing, Ltd., Bristol 2005).

470 CFI, 17 April 2008, Case T-389/03, Dainichiseika Colour \& Chemicals Mfg. Co. Ltd. V OHIM [2008] ECR II-00058, para. 61.

471 CFI, 11 July 2007, Case T-443/05, El Corte Ingles SA v OHIM [2007] ECR II-02579, para.37.

472 Cf. CFI, 12 September 2007, Case T-363/04, Koipe Corporación SL v OHIM [2007] ECR II-03355.

473 CFI, 12 June 2007, Case T-105/05 Assembled Investments (Proprietary) Ltd v OHIM, 
since "they are neither in competition with one another nor substitutable and not produced in the same area". Regarding the fact that "wine and certain articles of glassware are sometimes sold in the same places, such as specialist wine retailers"; the court found that such use of the same distribution channel was "a negligible proportion of the overall sales of the articles of glassware concerned" which could not cause confusion. ${ }^{474}$

Even where goods are regarded different in terms of their nature, purpose and method of use and for that matter not functionally complementary in the respective business sectors; may still be aesthetically complementally in the eyes of the relevant public. In the TOSCA BLU/TOSCA case ${ }^{475}$ in which goods in the fashion, body and facial care sectors were in dispute, it was held that such "aesthetically complementary nature must involve a genuine aesthetic necessity" to the extent that "one product is indispensable or important for the use of the other and consumers consider it ordinary and natural to use these products together". Thus, image of the product is central to the determination of the question whether goods are aesthetically complementary. ${ }^{476}$ This is particularly the case where, coordinating the various components of the external (image) look of the goods, the consumer is likely to perceive a connection between the goods concerned. ${ }^{477}$

The fact that goods appear in different classes does not necessarily lead to a conclusion that such goods are dissimilar. ${ }^{478}$ Nevertheless; classification of goods may remotely give a hint as to whether goods are similar. For instance, it has been held that since "goods in class 25 and those in class 18 are often made of the same raw material, namely leather or imitation leather"; such material similarity may be taken into account in assessing the similarity between the goods. ${ }^{479}$

[2007] ECR II-00060, para. 31.

474 CFI, 12 June 2007, Case T-105/05 Assembled Investments (Proprietary) Ltd v OHIM, [2007] ECR II-00060, para. 32.

475 CFI, 11 July 2007, Case T-150/04 Mülhens GmbH \& Co. KG v OHIM, [2007] ECR II02353 , paras. 35 to 39 .

476 "Goods such as shoes, clothing, hats or handbags may, in addition to their basic function, have a common aesthetic function by jointly contributing to the external image of the consumer concerned" ( $c f$. Case T-443/05 El Corte Ingles SA v OHIM [2007] ECR II-02579, para. 49).

477 CFI, 11 July 2007, Case T-443/05 El Corte Ingles SA v OHIM [2007] ECR II-02579, at [50].

478 "Classification of goods and services under the Nice Agreement is to serve exclusively administrative purposes" ( $c f$. Case T-389/03 Dainichiseika Colour \& Chemicals Mfg. Co. Ltd. v OHIM [2008] ECR II-00058, para. 62).

479 CFI, 11 July 2007, Case T-443/05 El Corte Ingles SA v OHIM [2007] ECR II-02579, para 42. 


\section{Likelihood of association}

Both Articles 8(1) (b) and 9(1) (b) conclude with a stipulation that "likelihood of confusion includes the likelihood of association". Some concerns may be raised as to whether the two terms are applied interchangeably. One may be persuaded, as the English High Court did, ${ }^{480}$ to conclude that the term "likelihood of association" adds nothing to the phrase "likelihood of confusion". Since likelihood of association is included in the likelihood of confusion, then likelihood of confusion is a genus while the likelihood of association is a species. Thus, likelihood of association would be presumed in every scenario in which likelihood of confusion is proved. In this sense, proof of likelihood of association is not a conclusive evidence of likelihood of confusion. Since a species cannot anticipate a genus, a genus has to be proved, in which case a species will be presumed. ${ }^{481}$ Thus, "the mere association which the public might make between two trade marks as a result of their analogous semantic content is not in itself a sufficient ground for concluding that there is a likelihood of confusion" within the meaning of the CTMR. ${ }^{482}$

While it can be conceded that likelihood of association is not an alternative to likelihood of confusion, the significance of the former must not be ignored as it serves to define the scope of the latter. ${ }^{483}$ To prove likelihood of association, one would be required to show that "on account of actual or likely use of the two marks, relevant consumers will be led to believe that the goods of the respective competitors are associated - perhaps because they have some common source or that one set of goods represent an extension of the product line of the other". ${ }^{484}$ Thus, establishment of likelihood of association is one step before establishment of likelihood of confusion.

\section{Trademark use as a condition for infringement}

Apart from a specific instance stipulated in Article 10 of the CTMR, under which the CTM proprietor is entitled to object to generic use of his trademark in

480 See Wagamama Ltd v City Centre Restaurants plc [1996] ETMR 307 (HC).

$481 C f$. Three Stripes trade mark [2002] ETMR 553.

482 ECJ, 11 November 1997, Case C- 251/95, Sabel BV v. Puma AG [1997] ECR I-06191, para. 26.

483 ECJ, 11 November 1997, Case C- 251/95, Sabel BV v. Puma AG [1997] ECR I-06191, para.18.

484 PHILIPS, J., "Trade Mark Law: a Practical Anatomy” 357 (Oxford University Press, Oxford 2003). 
reference works, which is not considered as a trademark use per se, a CTM infringement may only be justified if an infringing sign is used in the course of trade as a trademark. ${ }^{485}$

The phrase "in the course of trade", as it appears in Article 9(1), is not defined anywhere in the CTMR. However, from an etymological point of view, ${ }^{486}$ the phrase could mean that for a CTM infringement to take place, an infringing activity must be of a commercial nature undertaken "with a view to economic advantage, and not as a private matter". ${ }^{487}$ Thus, the infringer must be trading in the goods or services in relation to which the CTM proprietor claims the sign has been misused. Article 9(2) of the CTMR specifies some modalities of using a CTM as well as some activities, which may constitute use of a sign "in the course of trade" and "in relation to goods". It provides that:

The following, inter alia, may be prohibited under paragraph 1: (a) Affixing the sign to the goods or to the packaging thereof; (b) Offering the goods, putting them on the market or stocking them for these purposes under the sign, or offering or supplying services thereunder; (c) Importing or exporting the goods under that sign; (d) Using the sign on business papers and in advertising.

The ECJ has given some guidance in relation to the use requirement as a condition for infringement. In Arsenal Football Club ${ }^{488}$ the ECJ concluded that the rights of the CTM proprietor are not unlimited since he may only prohibit the use of sign identical to his CTM for goods identical to those for which the CTM is registered, provided that the use of the sign would affect the interests of the CTM owner, namely, the functions of a CTM, particularly the essential function of guaranteeing to consumers the origin of the goods. ${ }^{489}$

485 A trademark is used as a trademark as such if it "is used for the purpose of distinguishing the goods or services in question as originating from a particular undertaking". Cf. ECJ, Case C-63/97, BMW v Ronald Karel Deenik [1999] ECR I00905, para. 38. $C f$. also C-48/05, Adam Opel $A G$ [2007] ECR I-01017 which held that "where a trade mark is registered, inter alia, in respect of motor vehicles, the affixing by a third party, without authorisation of the proprietor of the trade mark, of a sign identical to that mark to scale models of that make of vehicle, in order faithfully to reproduce those vehicles, and the marketing of those scale models, do not constitute use of an indication concerning a characteristic of those scale models" (para. 45).

486 i.e. Legislative history, in view of the fact that the original 1964 draft of the CTMR spoke of "use in commerce".

487 KITCHIN, D., et al, "Kerly's Law of Trade Marks and Trade names" (4th ed.) 364 (Sweet \& Maxwell, London 2005).

488 ECJ, 12 November 2002, Case C-206/01Arsenal Football Club v Matthew Reed [2002] ECR I-10273.

489 Case C-206/01Arsenal Football Club v Matthew Reed [2002] ECR I-10273, paras. 51 and 54 . 
In view of the doctrine of constructive trademark infringement established in the Arsenal Football Club case "even where a trader uses a sign and at the same time explicitly denies the connection with the mark with a reputation there may be a likelihood of confusion" ${ }^{\text {"490; }}$; hence a trademark proprietor must be able to prevent that use. ${ }^{491}$ In the above case, Mr. Reed was selling football souvenir and memorabilia with some signs referring to Arsenal. Meanwhile, Arsenal was as well engaged on the same business under several of its registered marks such as "Arsenal" and "Arsenal Gunners". However, Mr. Reed had expressly disclaimed his commercial connection with arsenal football club by putting a large sign at his place of business which read: "the word or $\log$ (s) on the goods offered for sale, are used solely to adorn the product and does not imply or indicate any affiliation or relationship with the manufacturers or distributors of any other product, only goods with official Arsenal merchandise tags are Arsenal merchandise". The court nevertheless stamped the doctrine of constructive infringement by holding that "the use of that sign is such as to create the impression that there is a material link in the course of trade between the goods concerned and the trade mark proprietor", notwithstanding the likelihood that consumers who come across the mark at the point of sale would not confuse the origin of goods whereas those coming across the mark after the goods had left the point of sale would be confused. ${ }^{492}$ Given this likelihood, the use of the mark in the circumstances such as those in Arsenal's case would still be use of a trademark as a trademark as such in contravention of the CTM proprietor's interests even where it is apparent that the use of the infringing sign "is perceived as a badge of support for or loyalty or affiliation to the trademark proprietor". ${ }^{493}$

\section{Protection of a CTM with reputation}

\section{Reputation - what is it?}

Reputation is one of the elements that must be proved in order for the infringement under Article 9(1) (c) to apply. Reputation must be in relation to

490 Cf. MANIATIS, S. M., (2003), "Whither European Trade Mark Law? Arsenal and Davidoff: The Creative Disorder Stage”, 7 Marq. Intell. Prop. L. Rev. 99, 142 (2003).

491 Case C-206/01, Arsenal Football Club v Matthew Reed [2002] ECR I-10273, para. 61.

492 Case C-206/01, Arsenal Football Club v Matthew Reed [2002] ECR I-10273, paras. 57 and 61.

493 Case C-206/01, Arsenal Football Club v Matthew Reed [2002] ECR I-10273, operative part of the judgment. 
goods and/or services. The term "reputation", as used in the trademark context, refers to the "consequence of the fact that (i) consumers know that a trade mark is in use, (ii) competitors know that a trade mark is in use or (iii) consumers place a particular value on the trade mark in order to make or avoid making repeat purchases". ${ }^{494}$ Reputation must be appreciated in the EU, and, presumebly, on the date of the purported infringement. ${ }^{495}$

The absence of clear guidelines on how to categorise a CTM as a trademark with reputation renders it difficult for the proprietor to prove the existence of reputation in relation to his mark. The problem is exacerbated by the fact that any use of a particular mark will end up earning the mark concerned recognition in the commercial circles, however measurable and handful the reputation may be.

The ambiguity surrounding the extent of the reputation required under Article 9(1) (c) of the CTMR may be cleared up by distinguishing a trademark's reputation from a trademark's goodwill. It follows that:

The existence of 'reputation' is the consequence of the fact that consumers know that a trade mark is being used somewhere in the world. In contrast 'goodwill' is the consequence that, because consumers in a particular jurisdiction know that a trademark is used (in other words, that it has a reputation), they base their decision to purchase goods or services to which that trade mark is attached on the fact that they are attracted to those goods or services by virtue of the positive effect of the reputation. In this sense, goodwill would appear to be related to the concept of 'repute', the main difference being that a trade mark's 'repute' is its image in the eyes of the consumers while the 'goodwill' is the economic consequence of the trade mark having that image. ${ }^{496}$

In order to enjoin a third party from using an infringing sign, the CTM proprietor is duty-bound to prove that his mark has a reputation in the Community. He may thus base on the following factors to discharge his obligation:

(a) The degree of inherent or acquired distinctiveness of the mark; (b) The duration and extent of use of the mark in connection with the goods or services with which the mark is used; (c) The duration and extent of advertising and publicity of the mark; (d) The geographical extent of the trading area in which the mark is used; (e) The channels of trade for the goods or services with which the mark is used; (f) The degree of recognition of the mark in trade areas and channels of trade used by the mark's owner; and (g) The nature and extent of the same or similar sign by third parties. ${ }^{497}$

494 PHILIPS, J., "Trade Mark Law: a Practical Anatomy” 370 (Oxford University Press, Oxford 2003).

495 KITCHIN, D., et al, "Kerly’s Law of Trade Marks and Trade names" (4th ed.) 383 (Sweet \& Maxwell, London 2005).

496 PHILIPS, J., "Trade Mark Law: a Practical Anatomy" 177 (Oxford University Press, Oxford 2003).

497 These factors are mentioned in ANNAND, R. \& NORMAN, H., "Blackstone's Guide to the Community Trade Mark" 183 (Blackstone Press, London 1998). Cf. also Case C- 
Five types of use may be prohibited by the proprietor of a CTM with reputation. These are (i) the use which takes unfair advantage of the distinctive character of a proprietor's mark, (ii) the use which takes unfair advantage of the repute of this mark, (iii) the use which is detrimental to the distinctive character of the proprietor's mark, (iv) the use which is detrimental to the repute of this mark, and (v) the use of the proprietor's mark without any due cause. Pursuant to this categorisation, it is necessary to address the key terms such as unfair advantage, detriment and without due cause.

\section{a) Unfair advantage}

To contravene Article 9(1) (c) of the CTMR, the infringing sign must be used by a defendant in a way that enables him to take unfair advantage of the CTM's repute or distinctive character. Thus, unfair advantage is the result of the infringer's efforts and desire to free-ride "on the coattails of a famous mark or trading on its reputation". ${ }^{498}$ Such a desire on the part of an infringer is not allowed in view of the need "to protect the proprietor against competitors wishing to take advantage of the status and reputation of the trade mark". 499

The L'Oréal/Bellure case ${ }^{500}$ puts it clear that the phrase "taking unfair advantage of the CTM's repute or distinctive character" does not address the harm caused to the mark with a reputation but the unfair advantage taken by the third party as a result of the use of the identical or similar sign as a result of which the public establishes a link between a trademark with reputation and the infringing sign, without confusing them. Thus, the phrase "covers, in particular, cases where, by reason of a transfer of the image of the mark or the characteristics

75/97 General Motors Corporation v Yplon SA [1999] ECR I-05421 in which the ECJ has, for instance, required an earlier trademark with reputation to be known "by a significant part of the public concerned by the products or services covered by that trademark" (para. 26). However, clarifying on the extent of territorial recognition of a trademark with reputation, the ECJ pointed out that it was not a requirement that such a mark must have a reputation throughout the territory of the Member State, but only in a substantial part of it (para. 28), and that this substantial part may consist of just a part of one of the EU Member States (para. 31).

498 KITCHIN, D., et al, "Kerly's Law of Trade Marks and Trade names" (4th ed.) 384 (Sweet \& Maxwell, London 2005).

499 ECJ, Case C-63/97, BMWv Ronald Karel Deenik [1999] ECR I-00905, para. 52.

500 ECJ, Case C-487/07, L'Oréal SA v Bellure [2009] ECR I-05185, paras. 36, 37 and 41. 
which it projects to the goods identified by the identical or similar sign, there is clear exploitation on the coat-tails of the mark with a reputation". 501

\section{b) Detriment}

Detriment to the distinctive character or the repute of the CTM signifies that the infringer's activities harm or injure the CTM concerned in such a way that the CTM becomes "less attractive (tarnishing) or less distinctive (blurring)" ${ }^{502}$ The Intel case $\mathrm{s}^{503}$ elucidates on the concept of "detriment to the distinctive character of the earlier mark" - a concept which is interchangeably referred to as 'dilution', 'whittling away' or 'blurring'. According to the case, the concept is relevant when the ability of the earlier mark "to identify the goods or services for which it is registered and used as coming from the proprietor of that mark is weakened, since use of the later mark leads to dispersion of the identity and hold upon the public mind of the earlier mark" with the result that "the earlier mark which used to arouse immediate association with the goods and services for which is registered, is no longer capable of doing so". ${ }^{504}$

The concept "detriment to the repute of the mark" (otherwise referred to as 'tarnishment' or 'degradation') was given a judicial interpretation in the L'Oréal case. ${ }^{505}$ According to the school of thought in this case, a detriment to the repute of an earlier mark "is caused when the goods or services for which the identical or similar sign is used by the third party may be perceived by the public in such a way that the trade mark's power of attraction is reduced". A particular example of this concept would be where the "goods or services offered by the third party possess a characteristic or a quality which is liable to have a negative impact on the image" of the earlier mark.

501 Regarding how to determine the question whether the use of a sign takes unfair advantage of the distinctive character or the repute of the mark, refer to Case C-487/07, L'Oréal SA v Bellure [2009] ECR I-05185, para. 44.

502 KITCHIN, D., et al, "Kerly's Law of Trade Marks and Trade names" (4th ed.) 384 (Sweet \& Maxwell, London 2005).

503 ECJ, Case C-252/07 Intel Corporation Inc. v CPM United Kingdom Ltd [2008] ECR I08823.

504 Case C-252/07, Intel Corporation Inc. v CPM United Kingdom Ltd [2008] ECR I-08823, para. 29.

505 ECJ, Case C-487/07, L'Oréal SA v Bellure [2009] ECR I-05185, para. 40. 
c) Without due cause

The use of the term "without due cause" in Article 9(1) (c) implies that, under certain circumstances, a defendant is able to derive unfair advantage from, or to cause detriment to, the CTM in any of the ways explained above, without being held liable. To put it simply, a defendant can only be held liable if he fails to show due cause. A trademark use with due cause would therefore signify a different legal situation that may arise only when such a trademark use "can be justified by special circumstances which alter its basically illegal character". This would be the case, for instance, when the user of the mark is under compulsion to use a CTM with reputation or any other sign confusingly similar to the CTM in such a way that he cannot honestly be asked to refrain from doing so, notwithstanding the damages the owner of the CTM would suffer from such use, or where the user is entitled to the use of this very CTM in his own right and does not have to yield this right to that of the owner of the CTM. ${ }^{506}$

\section{$V$. Limitations to CTM rights}

A CTM registration does not give a proprietor a monopoly over a mark in all circumstances. Third parties may, for instance, use the very CTM owned by an independent person without infringing it. This possibility is clearly described under Articles 12 and 13 of the CTMR, just to mention but a few. ${ }^{507}$ While the legal entitlement to use a CTM pursuant to Article 12 of the CTMR is grounded on the honest use of the CTM by third parties, the entitlement under Article 13 of the CTMR implements the doctrine of CTM exhaustion. The contents of the two Articles are addressed below.

\section{Honest use of a CTM}

Where third parties use a CTM in a way that is considered honest according to practice of the relevant industry and commercial circle, the proprietor is not entitled to interfere with such use. Three types of use of a CTM by third parties are presumed honest, unless proved otherwise. These are (i) the use of one's own

$506 C f$. Benelux Court 01.03.1975 "Claeryn"/"Klarein" 7(3) IIC 420, 425 (176).

507 The limitations discussed under this part do not include, for instance, limitation in consequence of acquiescence, which is discussed infra in the part addressing opposition proceedings. 
name or address, (ii) descriptive use of the CTM, and (iii) use of a CTM to indicate the intended purpose of a product or service.

a) Use of one's own name and address

According to Article 12(a) of the CTMR, a CTM does not empower the proprietor to bar third parties from using in the course of trade their own names or addresses. The provision allows persons other than a CTM proprietor to use in relation to trade their personal designations, even where the designations concerned are identical or confusingly similar to the CTMR. ${ }^{508}$

A school of thought advocated for by the Council of the European Union and the Commission of the European Communities ${ }^{509}$ set forth a qualified interpretation $^{510}$ of Article 12(a) of the CTMR that the Article entitles only natural persons to exercise the right to the use of one's own name or address. In view of this school of thought it may seem that, in most cases the natural persons concerned, should be trading as sole traders. ${ }^{511}$

However, the ECJ provided a different interpretation which holds that, not only personal names, but also a trade name, may be based upon to enjoy the exception under Article 12(a) of the CTMR. ${ }^{512}$

508 Case C-404/02 Nichols plc v Registrar of Trade Marks [2004] ECR I-08499, paras. 33 and 34.

509 This school of thought is contained in the joint declaration issued by the EU Council and the Commission of the European Communities, and recorded in the minutes of the Council when Community Trade Mark Directive (i.e. Council Directive89/104/EEC harmonising trade mark law) was adopted. (See ECJ, Case C-245/02 Anheuser-Busch Inc. v Budéjovický Budvar, národni podnik, reported in the Official Journal C 219, 14/09/2002 P. 0004 - 0004, para. 78).

510 "A qualified interpretation" in the sense that statements of the Council and the Commission are not part of the legal text, hence they are without prejudice to the interpretation of the relevant legal text by the ECJ ( $c f$. ECJ, Case C-49/02 Heidelberger Bauchemie [2004] ECR I-06129, para. 17).

511 However, following the same school of thought, some forms of legal incorporation may qualify to exercise the right to one's name or address as per Article 12(a) of the CTMR. The specific example of this case would be where the incorporation concerned has no independent legal existence other than that of natural persons constituting it, as the case would be for a partnership registered in the United Kingdom. Under the immediately preceding example, partners of the firm would be allowed to adapt their own names (such as Brian \& Smith solicitors) as the designation of their firm without any liability to the CTM proprietor ( $c f$. Sections 1 and 5 of the UK Partnerships Act of 1890).

512 See Case C-245/02, Anheuser-Busch Inc. v Budéjovický Budvar, národní podnik, OJ C $219,14 / 09 / 2002$ P. 0004 - 0004, para. 81. 


\section{b) Descriptive use of a CTM}

Article 12(b) stipulates that a CTM shall not entitle the proprietor to prohibit a third party from using in the course of trade "indications concerning the kind, quality, quantity, intended purpose, value, geographical origin, the time of production of the goods or of rendering the service, or other characteristics of the goods or service". Article 12(b) of the CTMR is thus permissive of the descriptive use, made by third parties, of a protected CTM. An example of a descriptive use of a mark may be drawn from the fact that a juice manufacturer may not be prohibited from mentioning to consumers that his juice contains artificial sweetener of a certain type, even where, by so mentioning he makes use of a proprietor's CTM registered for sweeteners. Accordingly, a third party may use in course of commercial negotiation, without infringing, a proprietor's mark for the purposes of revealing the "origin of goods which he has produced himself", provided he uses the proprietor's mark "solely to denote the particular characteristics of the goods he is offering for sale so that there can be no question of the trade mark used being perceived as a sign indicative of the undertaking of origin". ${ }^{513}$

However, the descriptive use permitted under Article 12(b) seems to be controversial, since the descriptive use of CTM is likely to injure the proprietor's interests, particularly, by interfering with the guarantee of origin intimated in paragraph 8 of the preamble to the CTMR. This fear is, nevertheless, arrayed by the proviso to Article 12, described in $i v$ below, pursuant to which any purported descriptive use of CTM would be enjoined if it is not honest. ${ }^{514}$

c) Use of a CTM to indicate intended purpose

Within the ambit of Article 12(c) of the CTMR, a CTM does not bestow upon its proprietor a right to prohibit a third party from using in the course of trade the CTM "where it is necessary to indicate the intended purpose of a product or service, in particular as accessories or spare parts. ${ }^{515}$

513 Cf. Michael Hölterhoff v Ulrich Freisleben [2002] ECR I-04187, para.17.

514 See in this respect Case C-100/02 Gerolsteiner Brunnen GmbH \& Co. V Putsch GmbH [2004] ECR I-00691, para. 27.

$515 C f$. ANNAND, R. \& NORMAN, H., "Blackstone's Guide to the Community Trade Mark" 183 (Blackstone Press, London 1998). 
The ECJ decision, in Gillette case, ${ }^{516}$ reiterates that "use of the trade mark by a third party who is not its owner is necessary to indicate the intended purpose of a product marketed by that third party where such use in practice constitutes the only means of providing the public with comprehensible and complete information on that intended purpose in order to preserve the undistorted system of competition in the market for that product".

In the $B M W^{517}$ case, the ECJ considered the question whether informative use of a trademark by a third party infringed the exclusive rights of a trademark proprietor. In the case at hand, the defendant used the BMW mark in advertisements to inform the public that he carries out the repair and maintenance of BMW cars or he has specialised, or is a specialist, in the sale or repair and maintenance of those cars. The BMW Company objected to the defendant's use of the trademark, since the defendant, who carries on a garage business, used in course of trade the proprietor's mark. ${ }^{518}$ In the first place, the ECJ had to determine whether the defendant used a mark in dispute as a trademark as such. The court found that the mark was used as a mark ${ }^{519}$ even if infringement could only be upheld if the use complained of was not exempted under Article 12 of the CTMR.

The end results of the case as far as the application of Article 12(c) of the CTM is concerned concurred with the opinion delivered by the Attorney General Jacobs $^{520}$ who had opined that "if an independent trader carries out the maintenance and repair of BMW cars or is in fact a specialist in that field, that fact cannot in practice be communicated to his customers without using the BMW mark". 521

Thus, the defendant's use of the BMW mark in the $B M W$ case was not only considered legitimate but also honest within the meaning of the proviso to Article 12 of the CTMR, as in the circumstances described in the case the defendant observed "a duty to act fairly in relation to the legitimate interests of the trade mark owner". ${ }^{522}$

516 Gillette Company and Gillette Group Finland Oy v LA-Laboratories Ltd Oy [2005] ECR I-02337, Para. 1 of the operative part.

517 ECJ, Case C-63/97, BMWv Ronald Karel Deenik [1999] ECR I-00905, para. 33.

518 And given the fact that use of trademark in advertisements without authorisation is prohibited under Article 9(2) (d) of the CTMR.

519 ECJ, Case C-63/97 BMWv Ronald Karel Deenik [1999] ECR I-00905, operative part at [2].

520 Opinion of Mr. Advocate General Jacobs delivered on 2 April 1998 in ECJ, Case C63/97 BMW v Ronald Karel Deenik [1999] ECR I-00905.

521 ECJ, Case C-63/97 BMWv Ronald Karel Deenik [1999] ECR I-00905, para. 60.

522 ECJ, Case C-63/97 BMWv Ronald Karel Deenik [1999] ECR I-00905, para. 61. 


\section{d) Proviso to Article 12}

The proviso to Article 12 of the CTMR requires activities considered to be limitative to the rights enjoyed by the CTM proprietor, as may be undertaken by third parties, to be pursued "in accordance with honest practices in industrial and commercial matters". 523 According to the ECJ, "the condition of "honest practice' is, in essence, an expression of the duty to act fairly in relation to legitimate interests of the trade-mark proprietor". 524 Thus, the phrase "in accordance with honest practices in industrial or commercial matters" may be associated with the provisions of Article 10bis (2) of the Paris Convention. ${ }^{525}$ According to the provisions "any act of competition contrary to honest practices in industrial or commercial matters constitutes an act of unfair competition". Consequently, Article 10bis (3) mentions three instances of behaviour considered as not honest. Two of these behaviours, being directly relevant to the discussion on Article 12 of the CTMR, are worthy of verbatim quoting:

(1) all acts of such a nature as to create confusion by any means whatever with the establishment, the goods, or the industrial or commercial activities, of a competitor;

(2)...

(3) indications or allegations the use of which in the course of trade is liable to mislead the public as to the nature, the manufacturing process, the characteristics, the suitability for their purpose, or the quality, of the goods.

In the light of the above explanation, it is safe to conclude that an act, which on its face value would be permitted under the provisions of Article 12(a), (b) and (c) of the CTMR, will nevertheless be interdicted if it amounts to an unfair competition within the meaning of the provisions of the Paris Convention quoted above.

\section{Exhaustion of CTM rights}

Article 13(1) of the CTMR provides for the doctrine of trademark exhaustion by stipulating that "a Community trade mark shall not entitle the proprietor to prohibit its use in relation to goods which have been put on the market in the

$523 C f$. last sentence of Article 12 of the CTMR.

524 Case C-245/02 Anheuser-Busch Inc. v Budvar, reported in the Official Journal C 219, 14/09/2002 P. 0004 - 0004, para. 82. Cf. also Case C-100/02 Gerolsteiner Brunnen [2004] ECR I-00691, para. 24.

$525 C f$. ANNAND, R. \& NORMAN, H., "Blackstone's Guide to the Community Trade Mark” 183 (Blackstone Press, London 1998). 
Community under that trade mark by the proprietor or with his consent". In view of the above quotation, Article 13(1) of the CTMR establishes the principle of regional exhaustion of CTM rights.

Thus, the Article mirrors another instance where a CTM proprietor may not enjoin third parties from using his CTM in respect of goods and services, which have already been a subject of a sale done on the authority of a CTM owner. However, an exception, as contained in Article 13(2) of the CTMR, is applicable to the stipulation under Article 13(1) of the CTMR. The former Article excludes from application the provisions of the latter "where there exist legitimate reasons for the proprietor to oppose further commercialization of the goods, especially where the condition of the goods is changed or impaired after they have been put on the market".

The doctrine of regional exhaustion is considered in details in the context of the regime for the free movement of goods discussed in chapter six infra.

\section{Duties in relation to CTM}

\section{Renewal of CTM registration}

As opposed to other industrial property rights, a registered CTM may be protected for an indefinite period. ${ }^{526}$ While the CTMR sets out an initial validity term of 10 years, it provides a CTM proprietor with a possibility of renewing his trademark for unspecified number of times. ${ }^{527}$ Thus, the right to enjoy CTM rights beyond ten years is subject to the CTM concerned being renewed by the proprietor, whereas the right to unhampered enjoyment of CTM rights within any five years of registration is subject to the CTM concerned being used in commerce.

\section{Obligation to use a CTM}

Article 15(1) of the CTMR requires that a genuine use be made of a CTM in the Community in connection with the goods and/or services in respect of which the

526 Factually, CTM rights may be owned perpetually where the proprietor keeps on renewing the registration. Theoretically, however, a renewed CTM has a distinct legal existence as Article 47(5) of the CTMR provides that "renewal shall take effect from the day following the date on which the existing registration expires".

$527 C f$. Article 46 of the CTMR. 
CTM is registered. As a general rule, a CTM must be used within any five years following its registration. The Article was specially crafted to curb some incidences in which CTM holders would attempt to circumvent the use requirements by just using a CTM once in the first five years of its registration and suspend such use indefinitely, while retaining the CTM rights. ${ }^{528}$ Thus, within the ambit of the Article, some proper reasons for non-use must be given ${ }^{529}$ or else the non-use or suspension of a CTM use for a consecutive period of 5 years will render a CTM prone to revocation. ${ }^{530}$ Proper reasons for non-use are not expressly explained in the first sentence of Article 15(1). However, such reasons might exist in circumstances which are beyond the proprietor's control such as where the government prevents sale or marketing of the goods or services under the trademark for certain duration of time. ${ }^{531}$ A rule of reason would generally exonerate a CTM proprietor from losing his CTM rights provided he is not at fault for the non-use.

The ECJ jurisprudence addresses the requirement of genuine use of CTM. In Radetykz-Orden case, ${ }^{532}$ it was stated that genuine use was the opposite of a token trademark use actuated on the desire to preserve the rights conferred by the mark - a use which would be adjudged as inconsistent with the essential function of a trademark to serve as a guarantee of the identity of the origin of goods or services. ${ }^{533}$ Following the genuine use requirement, a CTM proprietor is obliged to use the CTM on the market for the goods or services protected by that CTM and not just internal use within the undertaking concerned. ${ }^{534}$

528 Recital 9 of the Community Trade Mark Directive states clearly the essence of the genuine use requirement: "In order to reduce the total number of trademarks registered and protected in the Community and, consequently, the number of conflicts which arise between them, it is essential to require that registered trademarks must actually be used, or if not used be subject to revocation."

529 This right to be given an opportunity to give reasons for non use is reinforced under the provisions of Article 5C (1) of the Paris Convention, which stipulates that "[If], in any country, use of the registered mark is compulsory, the registration may be cancelled only after a reasonable period, and then only if the person concerned does not justify his inaction".

$530 C f$. Article 51 of the CTMR.

531 KOOIJ, P.A.C.E. van der, "The Community Trade Mark Regulation: An Article by Article Guide" 44 (Sweet \& Maxwell, London 2000).

532 Case C-442/07, Verein Radetykz-Orden v Bundesvereingigung Kameradschaft 'Feldmarschall Radetzky ' [2008] ECR I-09223, para. 13.

533 On the concept of genuine use, cf. also Case C-495/07, Silberquelle GmbH v MaselliStrickmode GmbH [2009] ECR I-00137, para. 17; Case C-259/02, La Mer Technology Inc. v. Laboratoires Goemar SA [2004] E.C.R. I-1159, para. 1 of the operative part; Case C-40/01, Ansul [2003] ECR I-02439, paras. 35 and 36.

534 Case C-442/07, Verein Radetykz-Orden v Bundesvereingigung Kameradschaft [2008] ECR I-09223, para. 14. 
Article 15(1) (a) of the CTMR, provides as well some explanations as to which use may constitute genuine use of a CTM. Accordingly, "use of the Community trade mark in a form differing in elements which do not alter the distinctive character of the mark in the form in which it was registered" may still constitute a genuine use. ${ }^{535}$ Recognition of this mode of use is the logical consequence of Article 4 of the CTMR in the sense that a CTM is registered as long as it can distinguish goods or services it designates from goods or services designated by other signs. ${ }^{536}$ Hence, nothing would disqualify an italicised word mark, for instance, on non-use grounds where such word mark is used in a bolded font while retaining the distinctive character of the said italicised mark. Moreover, non-use may not be inferred from the fact that a CTM has been used only for export purposes. ${ }^{537}$ It will still constitute genuine use where the marked goods are not put on the European market but rather, being produced and the mark affixed in the EU Member State; the products were exported to be sold outside the EU borders. ${ }^{538}$

Article 15(2) of the CTMR provides a liberalised scenario pursuant to which a genuine use may be confirmed. Within the ambit of the Article, a constructive use of trademark by a proprietor is recognised where a CTM is used by a third party upon consent by the proprietor. Such consent may be express or implied from the underlying circumstances of each case. There is consent, for instance, "where the proprietor is a holding company allowing its subsidiaries to use the trade mark". 539

A CTM proprietor may consent to the use of his registered sign by issuing a license. License may be given for the use of a CTM in some parts of the Community. Thus, while a CTM must be valid for the whole Community, it is not necessarily that a license must cover the whole Community. Such license

535 Such use is also considered as a genuine use under Article 5C paragraph 2 of the Paris Convention.

536 However, there is no genuine trademark use where the trademark is used in relation to goods that are intended to be given as a gift to purchasers of some other goods marketed by the giver of the gifts, since in this scenario the items given free of charge "are not at all distributed with the aim of penetrating the market for the goods in the same class". In other words, affixing a trademark to items given free of charge "does not contribute to creating an outlet for those items, or to distinguishing, in the interest of customer, those items from the goods of other undertakings" (cf. Case C-495/07, Silberquelle GmbH v Maselli-Strickmode GmbH [2009] ECR I-00137, paras. 21and 22).

537 Cf. Article 15(1) (b) of the CTMR.

538 Article 9(2)(c) of the CTMR, regards as an infringement a use of a registered trade mark by a third party not having consent of a CTM proprietor. Thus, since a CTM proprietor enjoys exclusive of a CTM for export goods, such use is logically considered genuine.

539 KOOIJ, P.A.C.E. van der, "The Community Trade Mark Regulation: An Article by Article Guide" 44 (Sweet \& Maxwell, London 2000). 
will remain valid even if it is issued in respect of a single Member State or part of it. ${ }^{540}$ Consequently, the use made by a licensee in respect of a part of a geographical area in a Member State, will be accredited to the CTM proprietor as far as the CTM use requirement is concerned.

\section{Key principles relating to precedence of CTM rights}

\section{Priority Right}

Semantically, the term "Priority" means the right to precede others in order, rank or privilege. ${ }^{541}$ The decisive factor in deciding which signs precede the other is a priority date recognized under the CTMR. Article 29 of the CTMR is a legal foundation of the CTM priority right, and is built on the corresponding provisions of the Paris Convention. ${ }^{542}$ The Article stipulates that:

A person who has duly filed an application for a trade mark in or for any state party to the Paris Convention ... shall enjoy, for the purpose of filing a Community trade mark application for the same trade mark in respect of goods and services which are identical with or contained within those for which the application has been filed, a right of priority during a period of six months from the date of filing of the first application. ${ }^{543}$

Where a priority claim is made, ${ }^{544}$ the mark concerned may only become vulnerable to applications or registrations made before the priority date. Thus, under Article 31 of the CTMR, the date of priority counts as the "date of filing of the Community trade mark application for the purpose of determining which rights

Cf. Article 22(1) of the CTMR.

$541<$ http://dictionary.reference.com/browse/priority> (status: 30 July 2012).

542 i.e. Article 4 of the Paris Convention for the Protection of Industrial Property of March 20,1883 as revised.

543 Article 29(1) of the CTMR.

544 Priority right must be specifically claimed by including in the CTM application a declaration of priority and a copy of the previous application (cf. Article 30 of the CTMR). Pursuant to article 33 of the CTMR, priority claim may also be based on exhibition. However, priority right based on exhibitions differs from the one stipulated under article 29 of the CTMR. Whereas the latter is based on registration or application for registration, the former is based on exhibition of goods bearing the mark at an official or officially recognized international exhibition. To rely on the exhibition priority, a CTM applicant has to submit to OHIM evidence regarding the first date of the exhibition of the goods bearing the mark or of the services rendered under the mark during the exhibition. Thus, a CTM applicant will be required to submit a certificate issued by the competent authority of the exhibition stating the date on which the goods bearing the mark or the services rendered under the mark was first exhibited in connection with the goods or services. 
take precedence". In the circumstances, under the CTM system, as under any other trademark system "based on a first-to-file approach, the determination of the filing date has an overriding significance for both the applicant and holders of other rights, since priority and other precedence rights stemming from that date will affect the availability of the protected sign to third parties". .45

\section{Seniority right}

The right to priority stipulated under the CTMR should not be confused with the concept of "seniority" which is actually another form of precedence of rights. ${ }^{546}$ Under the concept, an applicant for Community trade mark may claim seniority of a national mark registered in a member state pursuant to Arts 34 and 35 of the CTMR. ${ }^{547}$ Thus, "seniority is a mechanism which allows a trade mark owner to consolidate his existing trade mark registrations in Member States under the 'umbrella' of a CTM registration". ${ }^{548}$ Seniority right is, nonetheless, used in the CTMR for ease of distinguishing priority rights claimable under the Paris Convention and those which are purely the creation of the Community law in its relation to trade mark law of the member states. ${ }^{549}$

\section{F. CTM Application and Opposition proceedings}

Article 6 of the CTMR identifies registration as a sole means by which CTMs may be obtained and protected. ${ }^{550}$ The mere use of a certain symbol as a trademark does not entitle the one who has adopted and used that symbol to

545 Blueco Limited's application [1999] E.T.M.R. 398, para. 12.

546 Timing is a demarcating line between the two seemingly same rights. While priority right is enjoyable within a certain period of time, the seniority right is limitless. Seniority right continues to be available to a proprietor of Community trade make even where the earlier national trade mark on whose basis seniority is claimable is surrendered or allowed to lapse (cf. Article 34(2)). Nevertheless, "failure to satisfy the requirements concerning the claiming of seniority of a national trade mark shall result in loss of that right for the application" (Article 36(6) of the CTMR).

547 These two provisions are discussed exhaustively in chapter 5 infra.

548 ANNAND, R. \& NORMAN, H., "Blackstone's Guide to the Community Trade Mark" 73 (Blackstone Press, London 1998).

549 The interface between the CTM system and the trademark system of the Member States is addressed under chapter 5 infra.

550 Cf. MARX, C., "Deutsches, europäisches und internationales Markenrecht" (2nd ed.) 404 (Wolters Kruwer Deutschland GmbH, Köln 2007). 
obtain a CTM protection by way of a registration in respect of that particular trade symbol.

\section{CTM application}

Some preliminary issues regarding an application for a CTM, such as a right to apply for a CTM, an entitlement to file a CTM application as well as the languages to be used in respect of such an application, may be highlighted.

In line with Article 5 of the CTMR, any person, whether natural or legal, has a right to become a proprietor of the CTM. Such a person cannot be disqualified from owning a CTM on the ground that he/she/it is not a citizen or resident of the European Union. ${ }^{551}$ The determination of the question, whether a particular body is a legal person entitled to own a CTM under the CTMR depends on how such a legal body is treated under a national law creating it. Thus, nothing will bar a legal person such as a company or a firm from owning a CTM, provided that a respective legal person enjoys under the national law, the right to conclude contracts, to sue and to be sued as well as to discharge any other legal obligetions in its own name. ${ }^{552}$

However, as regards a right to file a CTM application, the CTMR employs a different approach in two alternative ways. Any properly qualified trade-mark lawyer and a professional representative registered with OHIM is competent to file a CTM application, provided that he has secured a proprietor's power of attorney as an evidence of consent to such a representation. Similarly, a trademark proprietor may not need to be represented before OHIM if he has knowledge and skills needed for the processing of a CTM application, provided that, where a person concerned is not an EU citizen, he fulfils the condition of having business establishment in the EU. Thus, firms established outside the EU and, which have no business dealings within the EU, are incapable of filing a CTM application on their own. ${ }^{553}$

A CTM application has to comply with the language requirement stipulated under Article 119 of the CTMR. Essentially, any application tendered before

551 Prior to the amendment made to Article 5 of the CTMR by Council Regulation (EC) No 422/2004 of 19.2.2004, not every natural or legal person could own a CTM. Proprietorship of the CTM was dependent on various factors such as nationality and place of domicile of the natural or legal persons concerned. For a detailed account on the legal position before the 2004 amendment, see MÜHLENDAHL, A., et al, "Die Gemeinschaftsmarke" 21 and 22 (Staempfli Verlag AG, Bern 1998).

$552 C f$. Article 3 of the CTMR.

$553 C f$. Articles 92 and 93 of the CTMR. 
OHIM must bear one of the office's five languages, namely, Italian, Spanish, German, French and English. The rule is that in addition to the language in which the application is submitted, a CTM applicant has to choose an alternative language, which may be used in other proceedings relating to the CTM such as opposition and cancellation proceedings. A CTM application may, nevertheless, be tendered in a language other than OHIM's official languages provided a translation in one of the office's working language is made. It may thus be pointed out that the language's rules under the CTMR are flexible. For instance, a language in which the CTM application was filed may still be used for some proceedings before OHIM such as opposition, revocation, or invalidity, where the CTM proprietor is the only party to the proceedings. ${ }^{554}$

\section{Procedure and contents}

A CTM application may be filed either at OHIM or at the central industrial property office of a Member State or at the Benelux Trade Mark Office. It is left open for the applicant to decide where to lodge his CTM application. Applications submitted to central offices of the Member States have the same status as those filed directly at OHIM in Alicante, Spain. According to Article 27 of the CTMR, an application filed at the national industrial office or at the Benelux Trade Mark Office will acquire as its filing date the date on which all documents required by law to be included in the CTM application were filed at a relevant office provided that the application fee was paid within a month preceding the date when that application fulfilled the legal requirements. Unless applications, other than those filed directly at OHIM, are forwarded to OHIM within two weeks and, in any case, within a period not exceeding two months, such applications will be deemed to have been filed on the date on which the application reached OHIM. ${ }^{555}$

A CTM application must contain some information prescribed under Article 26 of the CTMR: a formal request for registration of a trade symbol as a CTM; identity of the applicant; information regarding the goods and services in respect of which registration of the trade symbol is requested; as well as a graphical representation of the trade symbol concerned.

As far as the identity of the CTM applicant is concerned, it suffices to point out that both natural and artificial persons may become proprietors of a CTM and hence entitled to file a CTM application. Whereas names, addresses and 
nationalities of the CTM applicants may serve to prove the applicants' identity, names of legal persons are indicated by their official designations and those of natural persons are indicated by their surnames and given names. ${ }^{556}$

Since the principle of trade mark certainty dictates that a CTM protection should only be in respect of goods and services specified in the application, ${ }^{557}$ a CTM applicant must expressly identify the goods and services which he intends to market or to offer using the mark applied for. He does so by classifying the goods and services in accordance with the "common classification referred to in Article 1 of the Nice Agreement Concerning the International Classification of Goods and Services for the Purposes of the Registration of Marks of 15 June 1957, as revised and amended". ${ }^{558}$ Moreover, in addition to paying a basic CTM application fee, the applicant is supposed to pay a "class fee for each class exceeding three to which the goods and services belong". 559

Representation of the mark applied for is likely to be very easy, especially where the applicant is not interested in securing CTM registration in respect of some isolated graphical features or colours, in which case the mark will be reproduced in normal scripts. This kind of reproduction may involve "typing the letters, numerals, and signs in the application". ${ }^{560}$

\section{Search procedure}

Article 38 CTMR provides for search procedure. The function of the search reports is to inform the applicant about prior rights which may conflict with the sign for which he has applied, so that he may take appropriate action even before publication. These search reports may result in the applicant withdrawing the application, if he finds there are clearly conflicting marks which will prevent him from obtaining a CTM registration and from using the mark in all Member States. ${ }^{561}$ Alternatively, he may amend the application, for instance by restricting the specification of goods and services in order to avoid a conflict of goods. Finally, he may take the matter up with the owner of the prior conflicting marks in order to seek an agreed solution.

$556 C f$. Rule 1 of the CTMIR.

557 Cf. GASTINEL, E. \& MILFORD, M., "The Legal Aspects of the Community Trade Mark" 98 (Kluwer Law International, The Hague 2001).

$558 C f$. Rule 2(1) of the CTMIR and Article 28 of the CTMR.

$559 C f$. Rule 4 of the CTMIR and Article 26(3) of the CTMR.

$560 C f$. Rule 3(1) of the CTMIR.

$561 C f$. KITCHIN, D., et al, "Kerly's Law of Trade Marks and Trade names" (4th ed.) 117 (Sweet \& Maxwell, London 2005). 
It may be deduced from the provisions of Article 8(1) that the search for earlier rights will be carried out in respect of identical trademarks for identical goods or services; similar trademarks for identical goods or services; similar trademarks for similar goods or services; and identical trademarks for similar goods or services. ${ }^{562}$ While the search report may form the basis for an opposition against a CTM registration, the opposition and cancellation divisions are not obliged to observe the outcome of the search. ${ }^{563}$ Similarly, the search report may not serve as a conclusive evidence as to whether or not a certain trade mark has a reputation in the community within the ambit of Article 8(5) of the CTMR. ${ }^{564}$

Before the revision of the Council Regulation (EC) No $40 / 94^{565}$ by the Council Regulation (EC) No 422/2004 of 19 February 2004, ${ }^{566}$ Article 39 of the revised Regulation required a mandatory national search to be carried out by the central industrial property office of all Member States participating in the system. For CTMs filed on or after 10 March 2008 (the date when the revisions of the Article came into force), the national search is no longer mandatory, but remains optional depending on the willingness of the CTM applicant to have a search conducted.

The old search system applied to all CTM applications made before 10 March 2008. Upon receipt of an application, OHIM was required to adhere to three basic steps, namely, to accord a filing date to a CTM application; to draw up "a Community search report citing those earlier Community trademarks or Community trademarks applications discovered" ${ }^{\prime 567}$ and to transmit a copy of the CTM application to the national trademark office of each Member State participating in the search system. ${ }^{568}$ The national office had to conduct a search

562 KOOIJ, P.A.C.E. van der, "The Community Trade Mark Regulation: An Article by Article Guide" 80 (Sweet \& Maxwell, London 2000).

$563 C f$. Articles 132 and 134 of the CTMR.

564 KOOIJ, P.A.C.E. van der, "The Community Trade Mark Regulation: An Article by Article Guide" 80 (Sweet \& Maxwell, London 2000).

565 OJ L 11, 14.1.1994, p. 1.

566 Some weaknesses inherent in the old search system led to the revision of Article 39 of the Council Regulation (EC) No 40/94. Lack of uniformity of national search reports is mentioned in the Commission report on the operation of the system of searches resulting from Article 39 of Council Regulation (EC) No 40/94. Cf. Commission document COM (2002) 754 final, available at <http://oami.europa.eu/pdf/mark/ec1.pdf $>$ (status: 30 July 2012).

567 The discovered earlier CTMs are those "which may be invoked under Article 8 against the registration of the Community trade mark applied for". Cf. Article 39(1) of the Council Regulation (EC) No 40/94 as it stood before 10 March 2008.

568 The copy of the CTM application is only sent to the trademark offices of the Member States which informed OHIM of their decision to operate a search in their registers of 
and submit a search report to OHIM within three months from the day it received a copy of CTM application. The national search report fulfils two connected objectives: it reveals earlier national rights or national trademark applications which can be invoked against registration of the CTM. ${ }^{569}$

According to the provisions of the revised Article governing the new search procedure, the search system is still very important: OHIM, upon according a filing date to the application, draws up a Community search report the same way it used to do in the old search system. ${ }^{570}$ Unless "at the time of filing a CTM application, the applicant requests that a search report also be prepared by the central industrial property offices of the Member States", OHIM is no longer obliged to send a copy of CTM application to the national trade mark office of the Member States. ${ }^{571}$

The new search system has made national searches optional. In order for a national search to take place three main conditions have to be fulfilled:

- Application for national search must be made together with the application for CTM registration.

- A request for a national search is only possible in the Member States which had informed OHIM that a national search report in respect of CTM application will be conducted by their central industrial property offices. ${ }^{572}$ Opting for a national search implies that all participating national offices will carry out the search. The applicant cannot decide to opt for few countries among the current 16 participating offices.

- The national search fee has to be paid within the time limit for the payment of the filing fee. This time limit is one month. If the optional search fee is not paid in time, the national search cannot be conducted.

However, some obligations that OHIM had in the old search system still apply in the new search system with slight modifications. For instance, under the old system OHIM had to transmit to the CTM applicant a Community search report and the national search reports, still it does the same under the new system. The only difference is the time limit within which OHIM has to transmit such reports.

trademarks in respect of CTM. Cf. Article 39(2) of the Council Regulation (EC) No 40/94 as it stood before 10 March 2008.

$569 C f$. Article 39(3) of the Council Regulation (EC) No 40/94 as it stood before 10 March 2008.

$570 C f$. Article 38(1) of the CTMR.

571 Cf. Article 38(2) of the CTMR.

572 By March 2008, only 16 European countries operated a national search in respect of CTM applications. These are Austria, Bulgaria, Czech Republic, Denmark, Finland, Greece, Hungary, Ireland, Lithuania, Poland, Portugal, Romania, Slovak Republic, Spain, Sweden and United Kingdom. 
Since the old search system allowed the national offices to submit search reports to OHIM within three months, OHIM could transmit the search reports to the applicant within three months as well. However, where the optional search is preferred and granted under the new system, the national office has the maximum duration of two months within which it has to submit to OHIM the national search report. OHIM has therefore to transmit such national search reports immediately to the CTM applicant after receiving them. ${ }^{573}$

Thus, both new and old search systems oblige OHIM to inform the proprietors of any earlier CTM rights or earlier CTM applications of the fact that a Community search report in respect of CTM application similar to, or closely resembling, theirs has been published. ${ }^{574}$ Publication of the CTM application is mandatory under Article 39 of the CTMR. Such publication allows proprietors of earlier rights to challenge registration of the published CTM application on the basis of relative grounds for trademark refusal.

\section{Opposition against CTM registration}

Where, in the opinion of OHIM, a particular sign has met the requirements of the CTMR,${ }^{575}$ such a sign will be registered as a CTM, provided no objection against its registration has been raised, or where such objection has been raised, it has not been successful, or has been withdrawn; and the registration fee has been paid. ${ }^{576}$

Opposition is a procedure which enables proprietors of earlier trademark rights to oppose registration of junior marks. The opposition proceedings are therefore "concerned with the ability of an applicant to acquire proprietary rights in the mark for which he sought registration". ${ }^{577}$ Oppositions may generally be based on relative grounds for trademark refusal mentioned under Article 8 of the CTMR. While third parties are not entitled to institute opposition proceedings before OHIM, they may still raise an objection against CTM registration. As a

573 See article 38(6) of the CTMR (new system) and Article 39(5) of the Council Regulation (EC) No 40/94 as it stood before 10 March 2008 (old system), respectively.

574 Cf. Article 38(7) of CTMR.

575 These requirements include those respectively described under Articles 4, 7, 8, 25 and 26 of the CTMR; namely, subject matter of the CTM registration, absolute grounds for refusal of registration, relative grounds for refusal of registration and conditions with which applications must comply.

$576 C f$. Article 45 of the CTMR.

577 PHILIPS, J., "Trade Mark Law: a Practical Anatomy” 425 (Oxford University Press, Oxford 2003). 
matter of law, a third party objection must be based on absolute grounds for trademark refusal. Hence, the objection procedure is distinguishable from opposition procedure in various ways which are discussed below.

\section{Objection procedure}

Since the CTM system is designed to accommodate the highest degree of transparency, third parties are allowed to submit their observations to OHIM where they think that a CTM applied for may not be registered because one or more of the absolute grounds for trademark refusal are applicable to the said mark. Following the publication of a CTM application, Article 40 of the CTMR entitles a prescribed group of third parties ${ }^{578}$ to communicate to OHIM their written observations pointing out some absolute grounds under Article 7 of the CTMR that are likely to defeat registration of the CTM applied for.

The aim of these observations is to move OHIM to reopen the examination procedure to see whether the absolute grounds of refusal put forward preclude registration of the mark claimed. Based on a need to comply with the European Convention on Human Rights ${ }^{579}$ enshrining a right to be heard, the above observations have to be communicated to the CTM applicant for possible comments. However, the right to submit observations is separable from the right enjoyed by the parties to the proceedings before OHIM.

Within the letters of the last sentence of Article 40(1) of the CTMR, persons submitting observations to OHIM are not parties to the proceedings before it. ${ }^{580}$ Since third parties have relatively limited and weaker rights in relation to CTM proceedings,${ }^{581}$ their observations cannot, in most cases, pose an insurmountable

578 These are "any natural or legal person and any group or body representing manufacturers, producers, suppliers of services, traders or consumers" (cf. Article 40(1) of the CTMR).

579 See in particular Article 10 of the European Convention on Human Rights signed in Rome on 4 November 1950.

580 Recall should thus be had to the position that pursuant to article 59 of the CTMR, an action may be brought before the Board of Appeal only by a party to a proceeding before OHIM. Additionally, under Article 65(4) of the CTMR, an action before the CTM courts is available only to parties to the proceedings before the Board of Appeal which led to the contested decision ( $c f$. CFI, 9 April 2003, Case T-224/01, Durferrit GmbH v. OHIM [2003] ECR II-01589, para. 74).

581 In view of the fact that they are not considered as parties to any proceedings before OHIM (cf. Article 40(1) of the CTMR). However, as of recent time, third party observers have regained some rights which they could not enjoy previously. For instance, Communication No. 1/00 of the president of OHIM dated 25 February 2000 concerning observations under Article 41 of the Council Regulation (EC) No 40/94 had 
threat to the registrant, since the CTM examiner will have considered all relevant absolute grounds before the publication of the CTM application. ${ }^{582}$ On the contrary, an opposition right remains the main stumbling block, which the CTM applicant must overcome in order to secure a CTM registration. ${ }^{53}$

\section{Grounds for opposition}

Proceedings relating to oppositions against CTM registrations are regulated under Articles 41 and 42 of the CTMR as well as under Rules 15 to 22 of the CTMIR.

Pursuant to Article 41 of the $\mathrm{CTMR},{ }^{584}$ an opponent has a maximum period of three months, counted from the date of the publication of a CTM application, ${ }^{585}$

limited the observer's rights only to the submission stage; meaning that he was not entitled to be informed specially on the action taken by OHIM in response to his observation, even if the observer retained a right to be informed on the OHIM's receipt of his observation and a confirmation that the applicant will receive such observation. While the above Communication remains OHIM's key document setting out the procedure of the Office concerning third party observations, it was amended in part by Communication No 3/02 of the President of the Office of 5 March 2002. According to this new communication, the observer is not only entitled to know the contents of the communication made to the CTM applicant by OHIM, but also to be informed about the action taken by the Office against the applicant.

582 Regarding this position see Articles 37(1) and 41(1) of the CTMR which indicate that in the normal examination procedure and before the opposition stage, "OHIM automatically examines whether registration of the mark claimed is precluded by an absolute ground of refusal" (cf. CFI, 9 April 2003, Case T-224/01, Durferrit GmbH v. OHIM [2003] ECR II-01589, para. 72).

583 A rough statistical data may reveal that "more than 20 per cent of CTM applications do not result in the registration of a CTM because of what happens during opposition proceedings" ( $c f$. GASTINEL, E. \& MILFORD, M., "The Legal Aspects of the Community Trade Mark" 110 (Kluwer Law International, The Hague 2001).

584 Article 41(1) of the CTMR provides that:

Within a period of three months following the publication of a Community trade mark application, notice of opposition to registration of the trade mark may be given on the grounds that it may not be registered under Article 8:

By the proprietors of earlier trade marks referred to in Article 8(2) as well as licensees authorised by the proprietors of those trade marks, in respect of Article 8(1) and (5); By the proprietors of trade marks referred to in Article 8(3); By the proprietors of earlier marks or signs referred to in Article 8(4) and by persons authorised under the relevant national law to these rights.

585 Publication date includes the date of republication of an amended application allowed under Article 43(2) of the CTMR (cf. Article 41(2) of the CTMR). On how the time limits enshrined in the CTMR are calculated see MÜHLENDAHL, A., et al, "Die Gemeinschaftsmarke" 94 (Staempfli Verlag AG, Bern 1998). 
within which to oppose registration of the CTM in the form it is applied for. ${ }^{586}$ Such opposition may be based on prior rights established under Article 8 of the $\mathrm{CTMR}^{587}$ mentioned in Section D(II) and discussed in Section E(I)(2) of this chapter. $^{588}$

\section{Entitlement to file a notice of opposition}

Given the various potential prior rights that may be invoked against a CTM application, the CTM applicant's chances of success plummet, whereas the position as to who may enjoy the locus standi to oppose is certain and stable. As a general rule, only a proprietor of earlier rights ${ }^{589}$ is automatically entitled to lodge a notice of opposition ${ }^{590}$ by advancing an argument that a particular trade symbol should not be registered as a CTM in view of his "pre-existing

586 BASTIAN, E.-M., KNAAK, R. \& SCHRICKER, G., (eds.) "Gemeinschaftsmarke und Recht der EU-Mitgliedstaaten“ 87 (Verlag C. H. Beck, München 2006).

587 On the basis of these prior rights, opposition proceedings are seen as a peculiar danger to the success of the CTM application. Since there are numerous prior rights, opposition to a CTM registration may base on a source in respect of which the applicant had no knowledge of its existence at the time when he filed his application. In the circumstances, even where the applicant is presumed to have acted with due diligence in searching for possible prior rights, he cannot discover some of the potential rights that end up ruining his chances of securing a CTM registration. This is the case particularly because some prior rights other than trademarks may entitle their owners to object registration of a CTM. These rights may, for instance, include copyrights or design rights. Moreover, oppositions may base on the "use of prior unregistered rights which cannot be searched and identified"; or may as well base on "prior and yet unpublished application to register a mark" ( $C f$. PHILIPS, J., "Trade Mark Law: a Practical Anatomy" 428 (Oxford University Press, Oxford 2003).

588 For an extensive discussion on the various prior rights stipulated under Article 8 of the CTMR $c f$. MÜHLENDAHL, A., et al, "Die Gemeinschaftsmarke" 36 (Staempfli Verlag AG, Bern 1998).

589 While persons other than the proprietor may lodge an opposition notice, where such notice is based on the grounds stipulated under Article 8(3), which deals with agent's mark, only the proprietor of the trademark is entitled to oppose registration of the mark concerned.

590 Thus, on the basis of this general rule, OHIM will always assume that the one lodging opposition notice is the proprietor of the earlier rights, hence no obligation on the part of owner of earlier rights to state in the opposition notice that he is the proprietor ( $c f$. “Opposition guidelines" (part 1) 20(OHIM 2007)). However, pursuant to Rule 15(2) (h) \& (i) of the CTMIR, an opponent who acts as a licensee or an authorised person has to include in the opposition notice his particulars such as a name and address as required under Rule 1 (1) (b) of the CTMIR. 
conflicting right", 591 namely; an earlier mark or particular sign used in business. $^{592}$ As an exception to the general rule, some categories of persons other than the proprietor may also enjoy the locus standi to oppose a CTM registration provided a relevant conditionality is met. Accordingly, within the ambit of Article 41(1) (a) licensees of trademark rights based on registrations or applications for registration as stipulated under Article 8(1) and (5) of the CTMR may file a notice of opposition in their own names, provided they are authorised by the owner. Similarly, on the authority of Article 41(1) (c) of the CTMR, persons authorised under the relevant national law to enjoy some rights in relation to earlier marks or trade symbols as described under Article 8(4) of the CTMR, are entitled to lodge a notice of opposition on their own. ${ }^{593}$

\section{Opposition proceedings}

After the notice of opposition has been received and examined by OHIM and found to be admissible pursuant to Rule 17 of the CTMIR, both parties are informed on the time limits of the opposition proceedings. The first stage of the proceedings is the "cooling-off stage" during which parties can negotiate aiming to secure an amicable solution or agreement. ${ }^{594}$ This stage lasts for two months with a possibility of extension of the period for up to 22 months and thus making the maximum duration for cooling-off to be 24 months. ${ }^{595}$ After the expiry of the

591 Cf. GASTINEL, E. \& MILFORD, M., "The Legal Aspects of the Community Trade Mark" 110 (Kluwer Law International, The Hague 2001).

592 These trademarks and signs may cumulatively be summed up as follows: "earlier identical trade marks for identical goods or services; earlier identical trade marks for similar goods or services; earlier similar trade marks for similar goods or services; earlier similar trade marks for identical goods or services; earlier identical trade marks for not similar goods or services; earlier similar trade marks for not similar goods or services; earlier trade marks, where an agent or representative of the proprietor applies for registration thereof without the consent of the latter; earlier non-registered trade marks or other signs used in the course of trade of more than mere local significance" (cf. KOOIJ, P.A.C.E. van der, "The Community Trade Mark Regulation: An Article by Article Guide" 84 (Sweet \& Maxwell, London 2000).

593 As an example of the rights protectable under the national law, one would cite Section 5(4) of the 1994 UK's Trade Mark Act which offers trademark protection under the law of passing off. One of the successful opposition based on passing off is Case R906/2001-1, Real Time Consultants v Manpower (Da Vinci device), O.J. OHIM 7-8/02, p.1427.

$594 C f$. Article 43(4) of the CTMR and Article 18(2) of the CTMIR, which entitle OHIM to "invite the parties to make a friendly settlement".

595 Nevertheless, any party to the opposition proceedings can bring to an end the cooling-off stage by sending a letter to OHIM. This possibility allows the parties to enjoy a freedom 
cooling-off stage, the parties are given four months to litigate the opposition. Out of these four months, the opponent gets two months to build up his case by submitting to OHIM all evidence, facts and observations on whose basis his opposition was tendered; ${ }^{596}$ whereas the CTM applicant will be given two months as well to respond to the opponent's evidence and arguments.

\section{Strategies and defences}

Opposition proceedings manifest a tug of war-like scenario. Where an opposition is lodged against a junior mark on the ground that the opponent owns an identical or similar senior mark or rights, the CTM applicant is entitled to attack his attacker by asking for evidence of genuine use made of the opponent's mark within the past five years. According to Rule 22(3) of the CTMIR it may suffice to discharge his obligation to provide proof of use of his mark if the opponent indicates the "place, time, extent and nature of use of the opposing trade mark for the goods and services in respect of which it is registered and on which the opposition is based". Evidence of such proof is particularly confined to the "submission of supporting documents and items such as packages, labels, price lists, catalogues, invoices, photographs, newspaper advertisements and statements in writings". ${ }^{597}$ Where the opponent opts to give statements in writings, they must be sworn or affirmed statements or statements having a similar effect under the law of the Member State in which the statement is made. ${ }^{598}$ Should the opponent fail to provide proof of use, he should then provide proper reasons for non-use; or else his opposition will fail. ${ }^{599}$

The case of Fiat veicoli Industriali S.P.A: (Iveco S.P.A.) v. Volkswagen AG $G^{600}$ demonstrates an instance in which an opposition against a CTM application was rejected by OHIM's Opposition Division on the ground that the opponent's mark was not put to genuine use as required under Article 42(2) of the CTMR. In this case, in order to sustain its opposition against registration of LUPO mark by Volkswagen, Fiat (the opponent) was required to furnish evidence of use of the mark (LUPO). The opponent (Fiat) failed to adduce satisfactory evidence

to go fast to the adversary stage (cf. Communication No 1/06 of the President of the Office of 2 February 2006 on extensions of the cooling-off period, which can be found at $<$ http://oami.europa.eu/en/office/aspects/pdf/co1-06en.pdf> (status: 30 July 2012).

$596 C f$. Rule 19 of the CTMIR.

597 Cf. Rule 22(4) of the CTMIR.

$598 C f$. Article 78(1) (f) of the CTMR.

$599 C f$. Article 42(2) of the CTMR.

600 [2000] E.T.M.R. 320. 
resolving the question whether Fiat had used the mark LUPO within five years preceding publication of the Volkswagen's CTM application. ${ }^{601}$

Moreover, the applicant may dispute the opponent's opposition by relying on Article 54(2) of the CTMR which bars a holder of senior trademark rights from opposing registration of a junior mark where the proprietor of senior mark acquiescence for a continuous period of five years in the use of his rights by third parties including a CTM applicant who later on seek to register the junior mark in his name. ${ }^{602}$

To carry forward the "tug-of-war concept", the CTM applicant is entitled to attack his attacker by alleging that the goods and services in respect of which the applicant seeks registration of the CTM applied for are different from those in respect of which the opponent's mark is protected. ${ }^{603}$ Where the danger of confusion is not dependent on the similarity between the junior and senior marks as well as similarity of the goods and services marketed under them, as the case is, for instance, with the well known or famous marks, the applicant may advance an argument disputing such a fame or a degree of knowledge on the part of consumers as far as the mark claimed to be famous or well known is concerned. While the opponent's proprietary interests in a mark, particularly a famous or well known mark, is hinged on goodwill generated by a respective mark, hence a reason to object free riding of the same, it must also be recalled that the logical basis for opposition is to avoid consumer confusion where the earlier and junior trademark rights are more or less the same. Thus, the opposetion will generally fail if the opponent is unable to prove to the satisfaction of the Opposition Division the existence of eminent danger of confusion.

The opposition proceedings in Brauerei Beck $G m b H \& C o$ case ${ }^{604}$ support the foregoing conclusion. In this case, the CTM applicant (Warsteiner) sought registration of the word mark ISENBECK for beer. The opponent (Brauerei Beck) opposed the registration on the basis of its earlier mark BECK's on the

601 The use evidence submitted by Fiat include a price list, newspaper advertisements and invoices which all together referred directly or indirectly to a trademark LUPO. The opponent also submitted lists of vehicles sold, evidence of use and a renewal certificate of mark "LUPETTO" which would be confused with LUPO - a contested mark. Nevertheless, the evidence revealed that the opponent did not use the mark within the five years period required under the law.

602 For the extensive discussion on the legislative history of the doctrine of acquiescence stipulated under Article 54 of the CTMR, $c f$. FERNANDEZ-NOVOA, C., "Die Verwirkung durch Duldung im System der Gemeinschaftsmarke", 45(4) GRUR Int 442 (1996).

603 See Article 8(1) (a) of the CTMR.

604 Brauerei Beck GmbH \& Co. v. Warsteiner Brauerei Haus GmbH \& Co. KG [1999] E.T.M.R. 225. 
ground that the applicant's mark was likely to be confused by the opponent's mark. The opponent argued that since it was also a proprietor of another trademark HAAKEBECK, public would take it for granted that beers whose names end with the suffix BECK were part of the family mark used to market beers brewed by the opponent. In disregarding the opposition, the Board of Appeal stated as follows:

While the products on which each mark were identical, there was no likelihood of confusion between them. There was little similarity between the marks in their appearance, or conceptual content. Even where there is an element which is common to the two marks (in this case, the word BECK), there is no likelihood of association between them unless the public understands that the element which is common refers in each case to the proprietor of the earlier mark, which could not be said to be the case here where ISENBECK would not convey the message of "a beer brewed by BECK". The claim that the public would assume there to be a series of beers brewed by Brauerei Beck on account of the use of "-beck" suffix would be disregarded in the absence of evidence as to whether, and if so to what extent, the HAAKEBECK mark was used.

It is noteworthy that where the opponent loses the case, he will be obliged to pay all costs of the suit. Pursuant to the provisions of Article 85(1) of the CTMR, "the losing party in opposition proceedings shall bear the fees incurred by the other party as well as all costs, without prejudice to Article $119(6)^{605}$ of the CTMR, incurred by him essential to the proceedings". ${ }^{606}$ Similarly, costs may also be apportioned. This is possible if both parties lose in part. Rules of equity require each party to bear its costs "unless the goods and services on which one party loses are clearly negligible". ${ }^{607}$

The Opposition Division is duty-bound to issue a reasoned decision at the end of opposition proceedings. Such a decision is notified upon the parties. A party aggrieved by the decision of the Opposition Division has a right under Article 58 of the CTMR to appeal against that decision. ${ }^{608}$ Such an appeal lies with the Boards of Appeal.

605 According to this Article, a party opposing registration of a particular CTM may be required, under the circumstances prescribed in the Article, to produce a translation of his application at his own expense.

606 See Brauerei Beck GmbH \& Co. v. Warsteiner Brauerei Haus GmbH \& Co. KG [1999] E.T.M.R. 225, 232.

607 Cf. "Opposition Guidelines" (Part 1: Procedural Matters) 58 (OHIM 2007).

608 Where an appeal is properly lodged, it "shall have suspensive effect" (cf. Article 58 of the CTMR). 


\section{G. Cancellation of CTM rights}

Cancellation is a legal concept, according to which CTM rights may either be revoked or invalidated. ${ }^{609}$ Revocation invalidates the CTM rights from the day on which such rights are revoked, whereas, as a result of successful invalidity proceedings, the respective rights are taken to have been non-existent from the time when registration certificate was issued by OHIM. Availability of the cancellation procedure under the CTMR affords to a person who would have objected to the registration of the mark, but for the limitation of time, an opportunity to challenge the validity of a CTM. ${ }^{610}$ Grounds for CTM revocation and invalidity are discussed below.

\section{Revocation}

The use of a CTM as described above, is central for determining the question whether a pertinent trade sign is prone to be revoked or not. Article 51 of the CTMR provides in no uncertain terms that "the rights of the proprietor of the Community trade mark shall be declared to be revoked on application to the Office or on the basis of a counterclaim in infringement proceedings" on the basis of non-use or, where allegations of non-use are rebutted by the proprietor, on the basis of improper use of a CTM.

\section{Non-use}

In order for a non-use of a trademark to constitute a ground for revocation of a CTM, the proprietor must not have complied with the provisions of Article 15 requiring him to put a mark on a genuine use within five years following registration. While Article 51(1) (a) of the CTMR reiterates the genuine use requirement, it additionally provides that even where there are no proper explanations for non-use of a CTM within the statutory period of five years, "no person may claim that the proprietor's rights in a Community trade mark should be revoked" provided that "during the interval between expiry of the five-year

$609 C f$. Article 56(3) of the CTMR.

610 This is particularly the case where invalidity issues are the basis for the cancellation proceedings. $C f$. BASTIAN, E.-M., KNAAK, R. \& SCHRICKER, G. (eds.), "Gemeinschaftsmarke und Recht der EU-Mitgliedstaaten" 88 (Verlag C. H. Beck, München 2006). 
period and filing of the application or counterclaim, genuine use of a trade mark has been started or resumed". Moreover, according to the rule laid down in the preceding Article, resumption of trademark use done within a period of three months after an application for revocation has been lodged or a counterclaim to that effect has be requested, may salvage the CTM from revocation only if its proprietor had not made such resumption or commencement of use after being tipped of the impending revocation application or counterclaim action. ${ }^{611}$ In other words, the proprietor must be judged to have resumed or commenced a trade mark use in good faith. ${ }^{612}$

\section{Improper use of a CTM}

A CTM may not only be revoked on the basis of non-use, but also on the basis of improper use. Article 51(1) (b) of the CTMR provides as a ground for revocation where because of certain acts or omissions of the proprietor with respect to the CTM use, the CTM is understood by the public as a "common name in the trade for a product or service in respect of which it is registered". To put it simply, improper use of a trade mark may turn a mark which was once distinctive into a generic mark. It is, nonetheless, incumbent upon the proprietor to salvage his trademark from becoming a generic name. He may do so by engaging on extensive marketing of the trademark while at the same time reinforcing the fact that his sign is not a generic but a brand name. The proprietor may additionally use the symbol ${ }^{\circledR}$, which is customarily accepted to signify that the trademark bearing it is registered or protected. Where piracy is a reason for the trademark losing its distinctiveness, the proprietor may reverse the situation by instituting legal proceedings against infringers. The outcome of the court proceedings will send a clear message to the consuming public that the trademark belongs to a particular source of products, in contrast to merely serving as a name of the products concerned. ${ }^{613}$

$611 C f$. BOMHARD, V. von, "Dormant Trademarks in the European Union - Swords of Damocles?" 96(5) TMR 1122, 1125 (2006).

612 The ECJ's jurisprudence reveals that, whereas in considering the question whether an alleged trade mark use is "genuine use" such consideration must be directed to the use made of the mark before the filing date of an application for revocation, trademark use after this period may be taken into account, provided that according to the circumstances of the case, such use does not reflect an intention on the part of the proprietor to defeat that application for trademark revocation ( $c f$. ECJ, Case C-259/02 La Mer Technology Inc. v. Laboratoires Goemar SA [2004] E.C.R. I-1159, para. 2 of the operative part.

613 SHYLLON, F., "Intellectual Property Law in Nigeria" 189 IIC Studies Vol. 21 (Beck, München 2003). 
However, the generic nature of a CTM under Article 51 of the CTMR must be distinguished from a generic mark addressed in the provisions of Article 7(1) (d) of the CTMR. While the former trade mark becomes generic due to inactivity or acts of the proprietor, the proprietor is not an instrumental in making the mark in the latter category generic. The mark in the latter category is inherently generic and its registration may be objected on the basis of absolute grounds described above.

Another mode of improper trade mark use which renders a CTM liable for revocation is stated in Article 51(1) (c) of the CTMR. The provisions warrant revocation of a CTM "if, in consequences of the use made of it by the proprietor of the trade mark or with his consent in respect of the goods or services for which it is registered, the trade mark is liable to mislead the public, particularly as to the nature, quality or geographical origin of those goods or services". However, there is a notable difference between the provisions of Article 51(1) (c) of the CTMR, which, accordingly, deals with the trade mark liable to mislead the public following the use made of it, and the legal import of Article 7(1) (g), addressing the trade signs which have potentialities to mislead the public ab initio. As a matter of law, the former provisions serve as a ground for revocation, while the latter serve as an absolute ground for refusal to register a trade sign as a CTM.

\section{Invalidity}

The rights of a CTM proprietor are not immune from being challenged. Third parties are empowered by the provisions of Articles 52 and 53 of the CTMR to challenge the legality of a registered CTM under certain circumstances. Two options are available to the one who seeks to challenge the existence of CTM rights: 1 . He may lodge his claim for invalidity directly with OHIM asking the Office to cancel the CTM, or; 2. if the CTM proprietor institutes infringement proceedings before a CTM court, the defendant may counterclaim by pleading that the registration of the CTM is invalid. ${ }^{614}$ The substantive justifications for invalidity proceedings are not based on whether such proceedings are instituted before OHIM or the CTM court; but rather on the existence of substantive and relative grounds for invalidity.

$614 C f$. Article 99(1) which stipulates as follows: "The Community trade mark courts shall treat the Community trade mark as valid unless its validity is put in issue by the defendant with a counterclaim for revocation or for a declaration of invalidity". 
Article 52 of the CTMR describes various legal scenarios whose proof renders a CTM absolutely invalid. Essentially, the CTM is to be declared invalid if the subject matter of the CTM registration did not meet the requirements of Article 7 of the CTMR. ${ }^{615}$ Thus, where the absolute grounds for trademark refusal skipped the mind of OHIM, and the registrar proceeded to register a sign as a CTM, Article 52 of the CTMR transforms the absolute grounds for trademark refusal under Article 7 of the CTMR into absolute grounds for invalidity.

A CTM registered in breach of Article 7(1) (b) (c), or (d) may not be invalidated on absolute grounds, if a sign covered by such a CTM has acquired a secondary meaning. ${ }^{616}$ In other words, "a trademark which is not distinctive, or is generic or descriptive, has nevertheless been registered, it cannot be declared invalid if, as a result of the use which has been made of it, it has, after registration, acquired a distinctive character in relation to the goods or services for which it is registered", 617

As a matter of principle, a proprietor should always act honestly when registering his trade mark. Thus, a CTM registration secured based on a bad faith will not withstand invalidity proceedings instituted on the basis of absolute grounds mentioned under Article 52(1) (b) of the CTMR. The "bad faith" mentioned in the above provision, have been interpreted to refer to a scenario where a CTM applicant is taken to have proceeded with the CTM registration notwithstanding a clear or imputed knowledge as to prior use of another trademark similar with or identical to his. ${ }^{618}$ However, the practice of OHIM's Boards of Appeal in relation to invalidity based on 'bad faith' shows that good faith will always be presumed unless the contrary is proved. The burden to render such proof is primarily placed on the cancellation applicant. ${ }^{619}$

615 Article 7 of the CTMR deals particularly with signs which are incapable of distinguishing goods or services of one undertaking from those marketed or offered by other undertakings. For the discussion on the Article $c f$. sction $\mathrm{D}(\mathrm{I})$ of this chapter.

$616 C f$. Section D (I) (7) of this chapter.

617 GASTINEL, E., \& MILFORD, M., "The Legal Aspects of the Community Trade Mark" 171 (Kluwer Law International, The Hague 2001).

618 KOOIJ, P.A.C.E. van der, "The Community Trade Mark Regulation: An Article by Article Guide" 103 (Sweet \& Maxwell, London 2000).

$619 C f$. the following decisions of the OHIM's Boards of Appeal: R 0336/2007-2 CLAIRE FISHER / CLAIRE FISHER; R 255/2006-1 JOHNSON PUMP; R 1264/2006-2 KREMOVY; and R 1265/2006-2 SMETANOVY. The decisions are cited in OHIM's Boards of Appeal: Yearly Overview of Decisions 2007, at p. 20, available at $<$ http://oami.europa.eu/en/office/aspects/pdf/BoAcaselaw2007_en.pdf $>$ (status: 30 July 2012). 
According to Article 52(3) of the CTMR, a CTM need not be invalidated in totality. Thus, a CTM may be invalidated partially. Partial invalidation is possible where for instance the mark is found not to be distinctive in respect of some goods covered by registration, hence it will be invalidated to the extent of its non-distinctiveness, while remaining valid in respect of the goods or services in connection with which it is distinctive. Thus, invalidity based on bad faith may deny the CTM's use only in respect of limited number of goods covered by the bad faith "scandal".

It is not an easy task to determine whether an application for CTM registration was made in bad faith. ${ }^{620}$ Nevertheless, the Colour of Elegance case ${ }^{621}$ throws some light on a legal interpretation of the phrase "bad faith". The case considers some fundamental issues such as "whether an application to register the Community trade mark THE COLOUR OF ELEGANCE for clothes should be withdrawn for bad faith" or "whether the proprietor of the trade mark ELEGANCE acted dishonestly by seeking to register the COLOUR OF ELEGANCE to prevent a competitor from launching an advertising campaign under that name". ${ }^{62}$ Accordingly, the Deutscher Bundesgerichtshof (i.e. the Germany Federal Supreme Court) held that:

A trade mark application in bad faith is to be presumed if the application is an abuse of the law or dishonest. The applicant for a sign, however, is not acting dishonestly simply because he knows that another is using the same sign in Germany for the same goods

620 The concept "bad faith" "is the functional equivalent to "fraudulently obtained registrations" under the Lanham Act". The concept "fraudulent registrations" under the Act has been construed by the U.S. Patent and Trademark Office (USPTO) as an "intentional deceitful practice or act designed to obtain something to which the person practicing such deceit would not otherwise be entitled. Specifically, it involves a wilful withholding from the Patent and Trademark Office by an applicant or registrant of material information or fact which, if disclosed to the Office, would have resulted in the disallowance of the registration sought or to be maintained" ( $C f$. PETRIN, M., "Cancellation of Fraudulent Trademark registrations under the Lanham Act and the European Community Trade Mark Regulation" 11(2) Intell. Prop. L. Bull. 161, 165 (2006-2007)).

621 Germany, Bundesgerichthof (Colour of Elegance) (I ZR 29/02), 37(2) IIC 226, 228 (2006).

622 The case concerns essentially a bad faith claim grounded on unfair competition. The plaintiff was using his unregistered mark ELEGANCE in Germany for a long time. When he got to know that the defendant was about to launch advertising campaign using a mark similar to the one adopted and used by the plaintiff in respect of goods identical or confusingly similar to those of the plaintiff; the plaintiff processed the registration of the said mark. However, the defendant went on to carry out his advertisements even after the mark has been registered. The plaintiff sued, and in course of the proceedings, the defendant entered a plea of counterclaim on the grounds that registration of the mark was secured on the basis of a bad faith. (Cf. 37(2) IIC 226 (2006). 
without having acquired formal trademark rights. However, the case may be different if there are particular circumstances on the part of the holder of the sign that cause the registration of the sign to appear dishonest within the meaning of the said provisions. ${ }^{623}$ Such circumstances could be that the sign holder, knowing the established interests of the prior user and without sufficient objective grounds, has the same or a confusingly similar sign registered for the same or similar goods with the aim of interfering with latter making use of the designation. Competitive dishonesty can also be found in a trade mark applicant's misappropriating the blocking effect that is created upon registration of the trade mark and that in terms of competition law is of itself unobjectionable, as a means of competition.

The "bad faith" doctrine is regarded to be a narrow concept within the ambit of the CTMR. ${ }^{624}$ Due to the lack of specific meaning of the phrase, efforts to expound it antithetically are on record. The OHIM's cancellation board has for example held "bad faith" to be the opposite of "good faith" signalled by an inference that a scheme used to secure a CTM registration was haunted by an actual or constructive fraud, or "an intention to mislead or deceive another including any sinister motive". ${ }^{625}$

The facts of the BE NATURAL case ${ }^{626}$ may throw some more light as to the meaning of the bad faith doctrine. A defendant, a UK resident, was a distributor of some "confectionary and health food bars" manufactured by an Austrian company (i.e. the applicant in the invalidity proceedings before OHIM) and sold under the mark "BE NATURAL". The applicant had registered the mark in Austria intending to register the same in the UK. Meanwhile, the UK distributor attempted to secure a UK registration of the mark BE NATURAL in his name without success because the UK Trade Mark Office had concluded that the distributor did not have a right to register the mark in question. However, the distributor sought, and succeeded, to secure a CTM registration for the said mark. OHIM cancellation division upheld the applicant's arguments supporting cancellation of the distributor's CTM. In view of the fact that the distributor's application for the registration of the mark in the UK was refused, it was held

623 The provisions concerned are Articles 52(1) (b) and 3(2) (d) of the CTMR and the Community trade mark directive respectively. Germany law on trade mark and other distinctive signs implements Article 3(2) (d) of the directive in its Sections 8(2), (10) and $50(1)$.

624 i.e. Article 52(1) (b) of the CTMR.

625 See OHIM, Cancellation Division, Decision in BE NATURAL, C000479899 (25 October 2000). See in particular paragraph 10 of the decision where OHIM adds that "bad faith can be understood as a "dishonest intention" ... that ... may be interpreted as an unfair practices involving lack of any honest intention on the part of the applicant of the CTM at the time of filing".

626 OHIM, Cancellation Division, Decision in BE NATURAL, C000479899 (25 October 2000), paragraph 4 . 
that the distributor's application to register the mark as a CTM was actuated by bad faith, particularly since he knew that, in his agent-principal relationship, the principal intended to register the mark; the distributor (i.e. an agent) wanted to pre-empt his principal/employer from registering the mark in the UK.

\section{Relative grounds for invalidity}

Relative grounds upon which a CTM may be declared invalid by OHIM or a CTM court are provided for under Article 53 of the CTMR. These are essentially the earlier rights mentioned in Article 8(2) to (4) of the CTMR, which entitle owner of a respective rights to oppose registration of a particular sign as a CTM. $^{627}$ Similarly, earlier rights such as a right to a name, a right of personal portrayal, a copyright; or an industrial property right "which may prohibit the use of a trademark pursuant to domestic system of law which governs that earlier right" 628 are also relative grounds for invalidity. However, the holder of the above earlier rights is not entitled to challenge a later CTM if he had expressly consented to its registration. It is important to note, where more than one earlier right forms part of the relative grounds for invalidity, such rights must be outlined in the first application for invalidity or in the first counterclaim in the infringement proceedings. Thus, a person invoking one or some of these grounds cannot be allowed to challenge the validity of a CTM basing on some grounds which were not invoked in the previous proceedings relating to the same CTM.

\section{Effects of CTM revocation and invalidity}

According to Article 55 of the CTMR, the rights which a CTM proprietor enjoys under the Community trade mark regulation, in particular the exclusive rights provided for under Article 9, are regarded not to have been effective as from the date of application for revocation or of the counter-claim. As one author points out, "the retroactive effect of any revocation of CTM rights does not affect decisions in infringement actions, which have become final and have been enforced prior to the revocation of CTM rights, subject to the application of relevant provisions of national law as to the remedies which might be available

627 See section D of this chapter, for a discussion on relative grounds for refusal to register a sign as a CTM.

628 GASTINEL, E., \& MILFORD, M., "The Legal Aspects of the Community Trade Mark" 172 (Kluwer Law International, The Hague 2001). 
as a result notably of unjust enrichment, or negligence, or bad faith on the part of the proprietor of a CTM" ${ }^{229}$ Similarly, a CTM revocation does not render void contracts whose conclusion predates the decision revoking the CTM, provided that the decision to revoke was reached well after the relevant contractual obligations have been discharged. ${ }^{630}$

The consequences of revocation and invalidity explained above may be distinguished in a peculiar sense: "the rights of the proprietor shall be declared to be revoked if the trademark or its proprietor no longer complies with the provisions laid down in the basic Regulation and in the Implementing Regulation. The trademark shall be declared invalid if the trademark or its proprietor did not comply with the said provisions as from the date of filing of the application". ${ }^{631}$ As a point of convergence, both proceedings for CTM revocation and those for declaration of invalidity are put into legal machinery in a similar manner: the CTM may be revoked or declared invalid by the CTM court pursuant to a counterclaim pleaded by the defendant in infringement proceedings. The CTM may as well be revoked or declared invalid by OHIM (acting through a Cancellation Division). ${ }^{632}$

\section{H. International Registration Procedure under the CTMR}

Trademarks "registered under international arrangements, which have effect in a Member State" or, which have effect in the EU, are mentioned in the CTMR as relative grounds for CTM refusal ${ }^{633}$ and as a basis for opposition ${ }^{634}$ and revocation $^{635}$ of a CTM.

629 GASTINEL, E., \& MILFORD, M., "The Legal Aspects of the Community Trade Mark" 160 (Kluwer Law International, The Hague 2001).

630 Nevertheless, "repayment of amounts paid under such contracts may, in certain circumstances, be claimed on grounds of equity" ( $c f$. GASTINEL, E., \& MILFORD, M., "The Legal Aspects of the Community Trade Mark" 160 (Kluwer Law International, The Hague 2001).

631 KOOIJ, P.A.C.E. van der, "The Community Trade Mark Regulation: An Article byArticle Guide" 100 (Sweet \& Maxwell, London 2000).

632 KITCHIN, D., et al, "Kerly's Law of Trade Marks and Trade names" (4th ed.) 136 (Sweet \& Maxwell, London 2005).

$633 C f$. Article 8(2) (a) (iii) \& (iv) of the CTMR.

634 Article 41(1) (a) of the CTMR.

635 Article 51 of the CTMR. 
Since the European Community is a signatory to the Protocol, ${ }^{636}$ international trademark registrations ${ }^{637}$ are, in the CTM context, governed by the Madrid Protocol. ${ }^{638}$ Trademark rights under the CTMR or applications for CTM processed by OHIM may be extended to other geographical territories outside the European Community. ${ }^{639}$ Similarly, protection under the CTMR may be extended to trademarks that were initially registered outside the jurisdictional territory of OHIM. These possibilities are discussed infra. ${ }^{640}$

\section{EC as a designated territory}

A process of designating the EC under the international trademark registration scheme established under the Madrid Protocol is initiated by the right holder (R) himself. Where the basis for R's application is a trademark registered in the country signatory to the Madrid Protocol, that basis is technically referred to as a basic registration; and where $\mathrm{R}$ bases his application for international registration on a pending trademark application at the trademark office in his country, his basis is technically known as a basic application. The trademark office in R's country is referred to as the office of origin. The office of origin works in cooperation with the WIPO office responsible for international registration

636 See the Proposal for a Council Decision approving the EC accession to Protocol Relating to the Madrid Agreement Concerning International Registration of Marks, adopted on June 27, 1989.

637 The term "international registration" should not be confused with the term "global trademark" as some listeners would tend to think. While the former refers to the system of trademark registration established under the Madrid Protocol, there is hitherto no international trademark regime that would confer global and unitary rights in respect of a single trademark symbol, which the latter connotes.

638 The Madrid Protocol, (relating to the Madrid Agreement concerning the International Registration of Marks concluded in 1891), which came into force on 1 April 1996.

$639 C f$. Article 145 of the CTMR.

640 The discussion is, however, not intended to be exhaustive as far as the international registration system is concerned. Since, only the interface between the Madrid Protocol and the CTM system is briefly addressed, technical issues, such as the consequences of cancellation of the national trademark on whose basis the international registration was secured, are not within the ambit of the discussion under this part. For an extensive discussion on the international registration with effect in the EU, please refer to the following literature: BASTIAN, E.-M., KNAAK, R. \& SCHRICKER, G. (eds.), "Gemeinschaftsmarke und Recht der EU-Mitgliedstaaten", 48-52 (Verlag C. H. Beck, München 2006); EISENFÜHR, G. \& SCHENNEN, D., "Gemeinschaftsmarkenverordnung“ (3rd ed.) 1285-1340 (Carl Heymanns Verlag, Köln 2010); and ANNAND, R. \& NORMAN, H., "Blackstone's Guide to the Community Trade Mark" 275-278 (Blackstone Press, London 1998). 
which is referred to as the international bureau. Thus, to realise his endeavour of designating the EU, $\mathrm{R}$ is required to ask the international bureau, (by either sending the application, containing the names of the countries where $\mathrm{R}$ wants his trademark to be protected, directly to the international bureau or channelling such an application through the national trademark office), to facilitate registration of the trademark in the countries that $\mathrm{R}$ has designated in the application. In case $\mathrm{R}$ designates the $\mathrm{EU}$, he will get an automatic trademark protection covering the 27 Member States. In other words, such a designation has the effect of an application for a CTM. ${ }^{641}$

One of the consequences of treating international registration designating the EU as an application for CTM is not only that OHIM takes charge of the procedural aspects of such processing, but also such an application is subjected to the very provisions of the CTMR regarding the formal and substantive requirements for trademark refusal. ${ }^{642}$ As far as an examination as to absolute grounds for refusal to which an international registration is subjected are concerned, OHIM may, depending on the outcome of the examination, react as hereunder:

- If, in OHIM's view, the basic application or the basic trademark registration (whichever in the case) does not meet the registration requirements under the CTMR, OHIM will issue ex officio notice of provisional refusal of the international registration. ${ }^{643}$

- In the event that the examination of absolute grounds reveals that the subject matter of international application contains an element which is not distinctive, the inclusion of which would make the scope of protection of the international registration doubtful, OHIM's ex officio notice may require the applicant to disclaim such an element as required under the provisions of Article 37 of the CTMR.

- Sometimes, the ex officio notice of provisional refusal of granting protection to the mark concerned is followed by a final refusal of international protection if the applicant does not take reasonable steps to furnish OHIM with a statement disclaiming a non-distinctive element in his trademark. ${ }^{644}$

$641 C f$. Article 3(4) and 3ter (2) of the Madrid Protocol.

$642 C f$. Article 154 of the CTMR.

643 Cf. Article 5(1) \& (2) and Rule 17(1) of the Madrid Protocol and the Common Regulation to the International Bureau. See also Rule 113 of the CTMIR.

644 Pursuant to Rule 115(1) of the CTMIR, ex officio notice of provisional refusal is issued in the event the international application is opposed. 
International application must comply with the language requirement to the same extent a normal CTM application does. ${ }^{645}$ Failure to satisfy the language requirement triggers OHIM provisionally to refuse the international registration. The applicant must overcome all the impediments contained in the notice of provisional refusal; otherwise OHIM enters a final decision refusing the grant of international registration. ${ }^{646}$ One of these impediments may be a notice of opposition levelled against the international application. ${ }^{647}$

As it is for opposition, the interested parties have a right under Article 158 of the CTMR to commence proceedings before OHIM with intention to invalidate the effect of international registration in the European Community. The procedure leading to this invalidation is equivalent to that of CTM revocation or invalidation. ${ }^{648}$

Regardless of whether protection of international registration is refused by OHIM or the effect of international registration ceases, still the applicant has two alternative remedies: he may either convert the international registration into the national trademark application in accordance with the provisions of Articles 112 and 114 of the CTMR $;{ }^{649}$ or designate the EC Member State which is party to the Madrid Protocol or the Madrid Agreement. ${ }^{650}$ A national trademark application or an application designating a member state pursuant to a conversion of an international registration designating the Community retains a priority date of the international registration. ${ }^{651}$

\section{CTM registration or application as a basis for international registration}

The CTMR provides for a procedure pursuant to which an application for CTM registration or a CTM registration itself may result in an internationally protected trademark. Article 146(1) of the CTMR is clear to this effect: "international applications pursuant to Article 3 of the Madrid Protocol based on an application for a Community trade mark or on a Community trade mark shall be filed at the Office". The applicant for international registration need not wait until the CTM

645 The OHIM's language regime is regulated under Article 119 of the CTMR and Rule 126 of the CTMIR.

$646 C f$. Rule 112(4) of the CTMIR.

$647 C f$. Article 156 of the CTMR.

$648 C f$. Articles 51 to 53 of the CTMR. See also Section 7 supra, which addresses cancellation of CTM.

649 See Chapter five infra, where the doctrine of CTM conversion is addressed.

650 See Rules 122 and 123 of the CTMIR.

$651 C f$. Articles 3(4) and 3ter(2) of the Madrid Protocol. 
registration is granted. He only needs to state whether a CTM application forms a basis for international registration or he waits until the CTM is granted. OHIM will act and submit an application for international registration to the international Bureau according to the trademark proprietor's wishes. In addition to observing the OHIM's official languages, the applicant for international registration must ensure that a translation in the language allowed under the Protocol is submitted. This is a case where the application submitted to OHIM is in a language (though OHIM's language) other than those allowed under the Madrid Protocol. ${ }^{652}$

However, "where a mark that is the subject of a national or regional registration in the Office of a contracting party is also the subject of an international registration and both registrations stand in the name of the same person, the international registration is deemed to replace the national or regional registration". ${ }^{653}$

This legal assumption does not apply if both registrations are not identical in terms of ownership, goods or services and where the national or regional registration is not senior to international registration. On this understanding, an international registration granted based on national or regional application for trademark registration is not useful in the context of replacement.

Although replacing national or regional registration with international registration results in an ostensible cheapness of renewal fees, it is advisable not to forgo earlier national or regional rights until such a period when dependency of rights lapses. ${ }^{654}$ Moreover, relying on a CTM application or registration to secure international registration is not completely a safe venture to undertake. In practice many months will elapse before OHIM publishes the examination report. Moreover, a greater proportion of CTM applications are opposed. ${ }^{655}$ The likelihood of the international trademark registration being opposed is exacerbated by the fact that, in practice, OHIM does not substantively examine on relative grounds (for conflict with earlier marks), ${ }^{656}$ but simply carries out a

652 While OHIM's languages are English, French, German, Italian and Spanish (cf. Article 119(2) of the CTMR), the Protocol's languages are English, French and Spanish (cf. Rule 6(b) of the Common Regulations under the Agreement and the Protocol).

653 Article 4bis (1) of the Protocol.

654 Cf. FIRTH, A., et al, "Trade Marks - Law and Practice" (2nd ed.) 258 (Jordan Publishing, Ltd., Bristol 2005). Regarding dependency of rights refer to Article 6(2) and (3) of the Madrid Protocol.

$655 C f$. FIRTH, A., et al, "Trade Marks - Law and Practice" (2nd ed.) 260 (Jordan Publishing, Ltd., Bristol 2005).

656 With regard to international registration, OHIM only checks the application in relation to entitlement to file on the basis of indication made in the OHIM form EM2 or WIPO Form MM2(Cf. Rule 103(2)(f) of the CTMIR). 
search and reports the outcome. ${ }^{657}$ Given the fact that the EU membership ranges to 27 Member States, the scope of opposition against CTM registration is considerable. ${ }^{658}$

$657 C f$. Article 38 of the CTMR.

658 Cf. FIRTH, A., et al, "Trade Marks - Law and Practice" (2nd ed.) 260 (Jordan Publishing, Ltd., Bristol 2005). 


\section{Chapter 5: Interplay between Community trade mark and trademark systems of EU Member States}

\section{A. Introduction}

Trade mark directive (henceforth, TD $)^{659}$ and Community Trade Mark Regulation (henceforth, CTMR) ${ }^{660}$ describe the interplay between CTM and trademark systems of the EU Member States. The TD aims to harmonise trademark laws of the EU countries. It requires all Member States to align their laws with its provisions so that fundamental principles governing registrability of signs as national trademarks in the Member States do not differ from those contained in the CTMR. ${ }^{661}$ For its part, the CTMR introduces a regional trademark regime with the unitary rights valid throughout the European Union. ${ }^{662}$ The CTMR does not replace, but supplements, the national trademark systems of the Member States. ${ }^{63}$ Under certain circumstances, rights established under the national systems may prevail over those established under the CTMR and vice versa. ${ }^{664}$ This is only one of the legal tactics employed in the CTMR to make sure that the system established under it remains unitary while in certain instances resorting to the rules established under the national laws, such as those relating to enforcement of CTM rights. ${ }^{655}$

659 Directive No 2008/95/EC of the European Parliament and of the Council of 22 October 2008 (codified version), which repeals the First Council Directive No. 89/104/EEC of 21 December 1988 to approximate the Laws of the Member States Relating to Trademarks.

660 Council Regulation (EC) No 207/2009 of 26 February 2009 on the Community trade mark (codified version), which repeals Council Regulation (EC) No 40/94 of 20 December 1993 on the Community trade mark.

661 See, for example, Article 2 of the TD requiring a registrable sign to be capable of being represented graphically. The same requirement is enshrined under Article 4 of the CTMR.

662 Cf. EDENBOROUGH, M., "The Free Movement of Trade Marked Goods in the European Community", in: POULTER, A., BROWNLOW, P., \& GYNGELL, J. (eds.), "The Community Trade Mark: Regulations, Practice and Procedures" (2nd ed., Release \#4) XII.7 (INTA, New York 2005).

663 The CTMR is independent of the TD. Its entire body of rules binds on all the EU Member States.

664 An instance of this scenario would be where earlier national trademark rights are relied upon to cancel a registered CTM, or where the CTM is relied upon to revoke a national trademark which was registered after the CTM's registration was secured.

$665 C f$. Article 14 of the CTMR. 
This chapter reviews some essential aspects of the CTM system, namely, seniority right, trademark conversion, and co-existence of CTM and national trademark rights. A space is also allocated in this chapter for a brief discourse on the impact that enlargement of the European Union has on the CTM system. The chapter further addresses the CTM enforcement regime. In this regard, the chapter covers institutions responsible for CTM enforcement and their powers, the law applicable to actual or threatened infringements, and the question of how judgments on CTM matters are recognised and enforced.

\section{B. Essential aspects of Community trade mark system}

The term "essential aspects of CTM", as used in this chapter, encompasses (i) the principle of co-existence of trademark rights protected under the national law and those protected under the CTMR; (ii) the principle of seniority of trademark rights; and (iii) the principle of trademark conversion.

\section{Co-existence of trade marks}

The question of co-existence of trademarks in the EU is the centrepiece of the system established under the CTMR. It had already been envisaged in the early phases of the adoption of the CTMR that since some enterprises would not find any economic motives to get their trademarks protected throughout the Community, national trademark systems should be left to co-exist with the $\mathrm{CTM}^{666}$ The CTMR stipulates a need to maintain a legal space within the national trademark systems in order to accommodate interests of persons who would just like to have a national legal security of their marks. It further sets out some mechanism to promote interests of proprietors who would like to extend their trade activities to the scale of the Community. ${ }^{667}$

The principle of co-existence affords to beneficiaries of the trademark systems in the EU an opportunity to choose from different trademark regimes under

$666 C f$. Article 6 of the pre-draft of the Regulation Relating to the Community Trade Mark of April 1977 (Document No. III/ex X1/C/268/77-E). The Article stipulated that: "This regulation shall be without prejudice to the right of Member States to maintain their national laws relating to trade marks". See also recital 6 of the CTMR, which insists on the need of co-existence of national and Community trademark rights.

667 SANDRI, S., "Community Trade Marks and Domestic Laws", in: FRANZOSI, M. (ed.) (1997), "European Community Trade Mark" 415 (Kluwer Law International, Boston 1997). 
which their trade marks may be protected. Trademark proprietors in the EU may apply for registration of their trademarks at national, regional and/or international levels. A trademark owner who does not want to trade beyond the national borders may opt for the national trademark registration. Those who attach great importance to the extension of their business beyond the national boundaries are likely to opt for a Community trademark registration.

An applicant for a trade mark registration has a number of factors to consider before opting for a particular registration scheme. The CTM would, for instance, be more cost effective than where a trademark proprietor attempts to register his trademark in each of the Member States aiming to secure multiple trademarks. Although the multiple national registrations in the Member States would substantially be equal to the CTM since all the EU countries have incorporated the TD provisions in their municipal trademark laws, this stratagem is more costly than obtaining a CTM. Where a trademark proprietor opts for a multipleregistration ruse, some duties in relation to maintenance of the trademark rights concerned such as the requirement of trademark use, renewal, and other proceedings relating to trademark cancellation and infringements have to be undertaken in each single country where a trade mark is registered. ${ }^{668}$ In contrast, proceedings relating to CTM are centralised and undertaken in a single procedure or process.

In the light of the foregoing, it is clear that a trademark proprietor may initially register his trademark, in a single Member State, as a national trade mark and apply for registration of the same mark as a CTM and vice versa. The principle of co-existence concerns a scenario in which a single trademark owned by a single, legal or natural person gets double protection as a national trademark and as a CTM. ${ }^{669}$

The double registrations of a trademark are likely to burden a trademark proprietor who has to maintain both national and CTM registrations. This burden may, nonetheless, be alleviated by the principle of seniority right, which allows the national trade mark and CTM registrations to be consolidated into one.

$668 C f$. POULTER, A., BROWNLOW, P. \& GYNGELL, J. (eds.), "the Community Trade Mark: Regulations, Practice and Procedure" (2nd ed., Release \#4) 14 (INTA, New York 2005)

$669 C f$. MÜHLENDAHL, A., OHLGART, D. C. \& BOMHARD, V. von, "Die Gemeinschaftsmarke" 10 (Staempfli Verlag AG, Bern 1998). 


\section{Seniority}

The principle of seniority facilitates the "merger of Community trade marks and identical earlier national registrations of the same mark for the same owner and for the same goods and services" ${ }^{670}$ Seniority is neither defined in the TD nor in the CTMR. While the CTMR makes reference to the right of seniority, the term is not mentioned in the TD. This omission is not accidental. The tenet of seniority is propounded under the CTMR ${ }^{671}$ to improve the CTM system in contrast to the national trademark systems. The principle of seniority motivates owners of earlier national trademarks to apply for registration of their mark as CTMs. The purpose of seniority right is "to make the Community trade mark an attractive option for persons who have already registered a particular trade mark in a number of Member States" and thus allowing the persons concerned an opportunity to take advantages of the CTM system stemming from financial savings and administrative convenience, which they would not otherwise enjoy "if they had to maintain their national registrations in addition to a Community trade mark" ${ }^{672}$ The principle, therefore, acts as a magnet that attracts proprietors of earlier national trademark to consolidate their national rights into a CTM without relinquishing the said national rights.

The legislative intent behind incorporation of seniority right in the CTMR is to enable owners of existing national trademarks to be the first to apply for registration of a corresponding $\mathrm{CTM},{ }^{673}$ since trademark proprietors "might be reluctant to abandon their national registrations unless they could be certain of retaining whatever rights they enjoyed as a result of those national registrations" ${ }^{674}$ Some fundamental issues in relation to the principle of seniority, such as the requirements for seniority, examination of seniority claim, and the merits and demerits of claiming a seniority right, are discussed below.

$670 C f$. Communication No $2 / 00$ of the President of the Office of 25 February 2000 concerning seniority examination, available at

$<$ http://oami.europa.eu/en/office/aspects/communications/02-00.htm $>$ (status: 30 July 2012).

$671 C f$. Articles 34 and 35 of the CTMR.

672 Cf. OHIM, Decision of the First BoA of 15 May 1998, Case R 5/97-1 (VICEROY), at [29].

673 Cf. FRANZOSI, M. (ed.), "European Community Trade Mark” 427 (Kluwer Law International, Boston 1997).

$674 C f$. OHIM, Decision of the First BoA of 15 May 1998, Case R 5/97-1 (VICEROY), at [29]. 


\section{Requirements for seniority}

In order to enjoy the seniority right, the owner of an earlier trademark must claim it. Such a claim must indicate (1) the status of earlier national trademark (i.e. the basis for a seniority right) and, (2) a proof that the earlier national trade fulfils the requirements of "triple identity rule".

\section{a) Status of the earlier national trademark}

In order to form a basis for seniority claim, a trademark concerned must be a national trademark, which is earlier than the CTM claiming such seniority. This implies that the earlier national trademark must have a filing date and priority date (where it is claimed) which is earlier than the filing date of the application for the CTM or the priority date which the CTM claims. ${ }^{675}$ Whereas under the national laws of some EU Member States, such as Germany, unregistered trademark rights are recognised ${ }^{676}$ such rights cannot confer on the proprietor a seniority right however senior and prior the unregistered trademarks may be. Only earlier and registered national trademark rights may be used as a base to claim a seniority right.

\section{b) Triple identity rule}

Three basic requirements, which Classical scholars categorically refer to as a "triple-identity rule" ${ }^{677}$ must be fulfilled in order to establish an entitlement to the right of seniority. Elements of the rule are analysed below.

675 MÜHLENDAHL, A., "Seniority” (ECTA's special newsletter no. 30 of May 1996) 19 (European Communities Trade Mark Association (ECTA) Secretariat, The Hague 1996).

$676 C f$. Section 4(2) of the German Law on Trade Marks and other Distinctive Signs of 1994 , as amended severally.

677 Cf. MÜHLENDAHL, A., "Seniority” (ECTA's special newsletter no. 30 of May 1996) 17 (European Communities Trade Mark Association (ECTA) Secretariat, The Hague 1996); BOMHARD, V. von \& PETERSENN, M., "Seniority under European Community Trademark Law", 92(6) TMR 1327, 1328 (2002); ANNAND, R. \& NORMAN, H., "Blackstone's Guide to the Community Trade Mark" 103 (Blackstone Press, London 1998). 
aa) Identity of the marks

Seniority right may only be validly claimed where the national trademark and the CTM are same. In contrast, where the CTM is just similar to the earlier national trademark, seniority claim will fail since, similarity is different from identity.

bb) Same owner

The second limb of the triple-identity rule reiterates the requirement of identity between the owner of the earlier national trademark and the owner of the CTM. In other words, the seniority claim may hold water only if the two marks are subject to a single ownership.

cc) Identical goods and/or services

The third appendage of the "triple-identity" rule dictates that, goods and services covered by the earlier national trademark must be identical with those covered by the CTM registration or by the CTM application. The enumeration of goods and services in the national trademark register is regarded as a maximum list in respect of which the earlier national trademark is registered and protected. Thus, a CTM or an application for a CTM registration protected or seeking protection only in respect of some of the goods and services covered by the national trademark may be considered to have met the requirement of identity of goods and services for seniority purposes. However, such a requirement is not met where a CTM or an application for a CTM exceeds the list of goods and services covered by the earlier national trademark. In the event the CTM or an application for a CTM exceeds the list of goods and services covered by the earlier national trademark, such goods or services in excess cannot be covered by the seniority right. ${ }^{678}$ To put it simply, "where the specifications differ, seniority can be claimed only with respect to the overlapping goods and services covered by the CTM and the national mark". ${ }^{679}$ Hence, a trademark proprietor is allowed to claim partial seniority.

678 MÜHLENDAHL, A., "Seniority” (ECTA's special newsletter no. 30 of May 1996) 29 (European Communities Trade Mark Association (ECTA) Secretariat, The Hague 1996).

679 BOMHARD, V. von \& PETERSENN, M., "Seniority under European Community Trademark Law”, 92(6) TMR 1327, 1330 (2002). 
Partial seniority claims are allowed in recognition of some difficulties, which trademark applicants or their representatives face while attempting to offer a precise delineation of the identical goods and services, in view of the fact that it might appear that the language of the earlier national registration differs from that of the CTM application. Consequently, OHIM is prepared to accept general or unspecified claims like "seniority is claimed for all the goods which are found in the earlier mark to the extent that they are also found in the application". ${ }^{680}$

\section{Examination of seniority claim}

Seniority claim may be lodged together with the application for CTM registration. OHIM is expected to act promptly, not only to examine the CTM registrability requirements, but also to examine whether the requirements for seniority claim have been met. However, in the light of a big number of seniority claims presented before the Office each year, ${ }^{681}$ OHIM has previously endorsed a policy allowing a CTM registration before examining the seniority claim. ${ }^{682}$ OHIM will, nevertheless, need some sound reasons before it decides to defer the examination of seniority claim to the time after the publication of a CTM application or registration (whichever is the case). It is, for instance, accepted

680 Cf. Communication No 1/97 of the President of the Office of 17 June 1997 concerning examination of seniority claims (paragraph 2, point III), available at $<$ http://oami.europa.eu/en/office/aspects/communications/01-97.htm> (status: 30 July 2012).

681 The 1996 OHIM's statistical data show that 25 per cent of all CTM applications during that year claimed one or more seniorities ( $c f$. Communication No 6/98 of the President of the Office of 14 November 1998 concerning examination of seniority claim (para. 1, point I), available at <http:/oami.europa.eu/en/office/aspects/communications/0698.htm> (status: 30 July 2012)). However, as an indication that proprietors of earlier national trademarks have been striving to merge their national marks with the CTM registrations by claiming seniority rights since the inception of the CTM system, the number of seniority claims dropped to 20 per cent of all applications in 2000 ( $c f$. Communication No 2/00 of the President of the Office of 25 February 2000 (para. 1, point I), available at <http://oami.europa.eu/en/office/aspects/communications/0200.htm> (status: 30 July 2012)).

682 Due to a large number of applications received in 1997, for instance, OHIM suspended the examination of seniority claim under Article 34 in order to concentrate all human resources on the processing of CTM applications from the application to the registration stages. Such a decision did not affect seniority examination under Article 35 of the CTMR, (see Communication No 6/98 of the President of the Office cited above). However, having reduced the CTM processing workload, OHIM resumed examination of seniority under Article 34 in 2000 (see Communication No 2/00 of the President of the Office, cited above). 
that a full-scale examination of seniority claims under the 'triple-identity rule' presents some difficulties, complexities and consumes a lot of time, hence the delay in processing applications for CTM. In these circumstances, deferral of the examination of seniority is not fatal as the "rights arising from seniority claims under Article 34 of the CTMR exist only after registration of the CTM and the surrender or lapse of the registration which is the subject of the seniority claim". ${ }^{63}$ Thus, under certain circumstances, suspension of seniority examination may not be adverse to, but pro, the proprietors' interests of securing exclusive rights in the CTM which would otherwise be delayed by the examination of seniority. ${ }^{684}$

In practice, and as far as seniority examination in respect of the "tripleidentity rule" (same goods, same proprietors and same trademarks) is concerned, OHIM examines one element only, namely, identity of trademarks. This practice takes into account the fact that changes affecting identity of goods and identity of proprietors, regarding both the earlier national trademark and the CTM registration, may occur between the time of tendering the seniority claim to the Office and the time when the proprietor may not renew the national registration in order to let it lapse. ${ }^{685}$ However, it does not mean that the other two elements, namely, identity of ownership and identity of goods and services, are less important. These elements must be specified in the seniority claim as well. Any obvious omission will render the seniority claim unsuccessful.

\section{Merits and demerits of seniority right}

\section{a) Merits}

Seniority right is accompanied by some appreciable advantages. The proprietor will enjoy double protection - first, in the country where earlier trademark rights existed, and second, at the Community level based on the CTM that assumed seniority right. Consolidation of earlier national trademark into a CTM is not a waiver of the national rights. The legal protection of the earlier national trademark remains intact. Such protection is not subjected to renewal requirements under the national law, provided the consolidated CTM is renewed as per

683 Communication No 2/00 of the President of the Office, cited above.

684 According to Article 9(3) of the CTMR, proprietary interests in a CTM can only be asserted against third parties after publication of a relevant CTM.

685 For further justifications regarding the practice, see Communication No 2/00 of the President of the Office, cited above. 
the CTMR requirements. ${ }^{686}$ Thus, claiming a seniority right minimises renewal and other administrative costs, since the trademark proprietor needs only to maintain the $\mathrm{CTM}^{6}{ }^{67}$ The principle of seniority right may, therefore, be seen as a contract between OHIM and the proprietors of earlier national rights seeking protection of these rights as CTMs. Under the terms of such a contract, the proprietor of a national trademark enjoys the right to seniority only if he forbears to renew the earlier national trademark, or if he allows it to lapse. As a consideration for such forbearance or abandonment, the national trademark will be deemed under the CTMR to remain validly registered under the national law of the Member State concerned. ${ }^{688}$

\section{b) Demerits}

Under certain circumstances, seniority right may be compromised. This is particularly a case inscribed under Article 34(3) of the CTMR. According to the Article, "[the] seniority claimed for the Community trade mark shall lapse if the earlier trade mark the seniority of which is claimed is declared to have been revoked or to be invalid or if it is surrendered prior to the registration of the Community trademark". Pursuant to the forgoing provision, the fate of the seniority right claimed before a CTM registration is dependent on the continued validity of the earlier national trademark, which serves as the foundation for such seniority. Any successful legal action (such as invalidity and revocation proceedings) challenging the validity of the earlier national trademark undertaken before the seniority claim has been accepted by OHIM, will result into the loss of the seniority right. While the proprietor has a right to surrender or to decide not to renew the earlier national trademark right even before the CTM is registered, in the event he does so before the seniority claim is accepted he will lose the seniority claim. ${ }^{689}$

The CTMR does not guarantee that a CTM consolidating the earlier national trademark cannot be challenged. Registration of a CTM can be challenged based on earlier trademark rights. Even where these earlier rights are not earlier than the national trademark on whose basis the seniority right was claimed, the

$686 C f$. Article 47 of the CTMR.

687 Cf. AIDE, C.M. \& DITTMER, S., "Registration and Enforcement of European Community Trade Marks: A Practical Guide", 14 I.P.J. 283, 292 (1999-00).

$688 C f$. Article 34(2) of the CTMR.

$689 C f$. DURAN, L. \& ANNAND, R.E., "Seniority", in: POULTER, A., BROWNLOW, P. \& GYNGELL, J. (eds.), "the Community Trade Mark: Regulations, Practice and Procedure" (2nd ed., Release \#4) VI.38 (INTA, New York 2005). 
validity of the CTM concerned can still be questioned. Imagine a scenario in which two national trademarks (i.e. NTM1 and NTM2), which were registered in different Member States in 1970 and 1993 respectively, are in issue. Suppose further that in 1994 the proprietor of NTM1 successfully registered a CTM and claimed the seniority right of his 1970 national trademark. Under this scenario, the proprietor of NTM2 may challenge the validity of a CTM even if NTM2 is very junior to NMT1. NTM2 can, thus, be based upon as a relative ground for a CTM refusal. ${ }^{690}$ This is the result of the territoriality principle of trade mark rights, which holds a particular national trade mark as valid only in the country where such mark is registered.

In view of the above conclusion, it is clear that seniority right is not entirely a safety valve, since various national trademarks unknown to the proprietor of NTM1 may be based upon to challenge his CTM. In the circumstances where the CTM is challenged as above, the principle of trademark conversion enables the proprietor to transform his CTM registration into national registrations.

\section{Trade mark conversion}

A CTM proprietor has a right to convert his CTM registration or application into national trademark applications in the Member States where similar trademarks do not exist. The right and the procedure leading to conversion are regulated under Articles 112 to 114 and 159 to 161 of the CTMR as well as Rules 44 to 47 and 122 to 124 of the CTMIR. It is important to note that:

The national trade mark application resulting from the conversion of a Community trade mark application or a Community trade mark shall enjoy in respect of the Member State concerned the date of filing or the date of priority of that application or trade mark and, where appropriate, the seniority of a trade mark of that State claimed under Articles 34 or $35 .{ }^{691}$

\section{Grounds for conversion}

a) Withdrawal of a Community trade mark application

An applicant for a CTM registration has a right, pursuant to Article 43(1) of the CTMR, to withdraw his application. This may happen, for instance, where a

$690 C f$. in this respect Article 8 of the CTMR.

$691 C f$. Article 112(3) of the CTMR. 
CTM applicant learns about the existence of some prior rights after he had already applied for a CTM registration. Article 112(1) (a) of the CTMR permits a person who has withdrawn his application for a CTM registration to convert the application into applications for national trademarks. Only a CTM application, to which a filing date has been assigned, in accordance with Article 26(1) of the CTMR, may confer a right of trademark conversion. A CTM application may, nevertheless, retain an original filing date only if the trademark proprietor pays a basic application fee within a month following a date, on which the competent office received the application. Thus, a trademark application withdrawn before a basic application fee is paid does not confer a right of conversion to the trademark proprietor. Under certain circumstances, a CTM applicant may be deemed to have withdrawn his application. ${ }^{692}$ A constructive withdrawal, for instance, will be confirmed if the class fees, ${ }^{693}$ or if the registration fee is not paid within a prescribed period, or when a central trademark office of the Member State fails to forward to OHIM a CTM application channelled through it. ${ }^{694}$

b) Cessation of effects of Community trade mark

A CTM shall cease to have effect if it is not renewed, if it is surrendered, or if it is cancelled. ${ }^{695}$ If the effects of a CTM cease, the proprietor has a right, under Article 112(1) (b) of the CTMR to convert it into national applications for trademark registration.

\section{c) Refusal of registration}

A trademark must be refused registration, unless it fulfils the conditions for CTM registration. ${ }^{696}$ Article 112(1) (a) permits a proprietor whose CTM application has been refused registration to convert the refused application into applications for national trademark registrations. It is important to note that registration of a

$692 C f$. Articles 36(5) and 45 of the CTMR.

$693 C f$. Article 36(1) (c) of the CTMR requiring fees to be paid for each class applied for.

694 Cf. Article 25(3) of the CTMR. See also McGOVERN, P., "Conversion", in: POUlTER, A., BROWNLOW, P. \& GYNGELL, J. (eds.), "the Community Trade Mark: Regulations, Practice and Procedure" (2nd ed., Release \#4) IXA.8 (INTA, New York 2005).

695 See, respectively, Articles 47, 50 and 55 of the CTMR.

696 See the grounds for trademark refusal in section D of chapter 4. 
trademark can be approved in part (i.e. in respect of some of the goods and services). If this happens, the proprietor shall have the right to convert the mark into national applications for the goods and services in connection with which a CTM registration has been refused.

d) Successful cancellation proceedings

A CTM registration may be cancelled either by being revoked or by being invalidated ${ }^{697}$ Cancellation of a CTM may be based on some grounds available in a single Member State. In the circumstances, the proprietor can be allowed to convert his CTM into national registrations in the Member States where grounds for cancellation do not exist.

2. Grounds for excluding conversion

a) Non-use of a Community trade mark

Article 15 of the CTMR warrants revocation of a CTM, which has not been put to genuine use. ${ }^{698}$ According to Article 112(2) (a) of the CTMR, a CTM revoked on non-use grounds does not confer on the proprietor a right of conversion.

b) Grounds for refusal available in one Member State

Within the ambit of Article 112(2) (b) of the CTMR, a CTM cannot be converted into a national trademark in the Member State where, due to some grounds for trademark refusal or for revocation or for invalidity available in this Member State, the subject matter of a CTM registration would not have been registered as a national mark. However, such a trademark can be converted into national trademarks in other Member States where no such prior rights exist.

697 See respectively Articles 51 and 52 of the CTMR.

698 Regarding the use requirement, see section E (VI) (2) of chapter 4. 


\section{Enlargement of the European Union and Community trade marks}

Any accession to the European Union by new Member States impacts on the CTM. ${ }^{699}$ Arrangements have to be made to ensure that the unitary character of a CTM and the rights protected in the new Member States before accession date are not affected. To facilitate integration of national trademark systems of new Member States into the CTM system, two solutions were conceived, namely, automatic extension of earlier CTMs and the "possibility for the holders of earlier national rights in the new Member States to prohibit the use of such extended Community rights in case of conflict". ${ }^{700}$

\section{Automatic extension of Community trade marks}

A registered CTM, or an application for a CTM registration made, before the date of accession of a new Member State, extends automatically to the territory of this new Member State. This is what Article 165(1) of the CTMR stipulates.

\section{Absolute grounds for trademark refusal}

Accession of new Member States to the EU results in "potential conflicting additional new prior" or earlier trademark rights. ${ }^{701}$ It might happen that, in the light of a language in use in the acceding State, a registered CTM becomes descriptive of the goods or services it markets. Under the general rules, ${ }^{702}$ this CTM must be cancelled. However, a special provision was enacted in the CTMR to the effect that, no registration of a CTM applied for before the date of accession may be refused on the basis of absolute grounds for trade mark refusal, which becomes relevant upon accession of this new Member State. ${ }^{703}$ This does not, nevertheless, "mean that Community trade mark of this nature, once

699 Cf. GASTINEL, E. \& MILFORD, M., "The Legal Aspects of the Community Trade Mark" 143 (Kluwer Law International, The Hague 2001).

$700 C f$. Communication No 05/03 of the President of the Office (i.e. OHIM) of 16 October 2003, available at <http://oami.europa.eu/en/office/aspects/communications/05-03.htm> (status: 30 July 2012).

$701 C f$. GEVERS, F. \& PIRE, J. L., "European Union, Enlargement to ten new Member States and the impact on the Community trade mark" in: POULTER, A., BROWNLOW, P., \& GYNGELL, J. (eds.), "the Community Trade Mark: Regulations, Practice and Procedure" (2nd ed., Release \#4) XIII.7 (INTA, New York 2005).

$702 C f$. Article 7(1) of the CTMR.

$703 C f$. Article 165(2) of the CTMR. 
registered will necessarily create a monopoly in a descriptive word in the new Member States where the absolute ground for refusal existed before enlargement". ${ }^{704}$ Thus, depending on the meaning that the word mark conveys to the mind of the consuming public in the acceding State, a CTM may be outlawed in this State, without affecting the validity of a CTM and the use of that CTM in other Member States.

\section{Opposition against registration of Community trade marks}

A CTM applied for during a period of six months prior to the date of accession may be opposed by a proprietor of an earlier national trademark protected in the acceding State. This may happen only if the earlier national trademark was acquired in good faith and has a filing date or priority date (if claimed), which is earlier than that of the CTM application. ${ }^{705}$ This kind of opposition need not conform to the provisions of Article 41 of the CTMR requiring an opposition to be lodged within three months after publication of the CTM application.

\section{Cancellation of Community trade marks}

If an application for CTM registration is not opposed as above, no cancellation proceedings may be instituted against it on the basis of absolute and relative grounds for invalidity available in the new Member State. Similarly, a counter claim for the invalidity of a CTM cannot be approved if the ground for the counter claim becomes relevant due to some facts discovered in the acceding Member State. ${ }^{706}$ To put it simply, "extended CTMs can only be cancelled on the basis of a ground that was valid at the time before enlargement (meaning that they cannot be cancelled on the basis of grounds that become applicable merely because of accession)". ${ }^{707}$

704 Cf. FOLLIARD-MONGUIRAL, A. \& ROGERS, D., "the Community trade mark and designs system and the enlargement of the European Union", 26(2) E.I.P.R. 48,49 (2004).

$705 C f$. Article 165(3) of the CTMR.

$706 C f$. Article 165(4) of the CTMR.

$707 C f$. Communication No $05 / 03$ of the President of the Office (i.e. OHIM) of 16 October 2003, available at $<\mathrm{http} / /$ oami.europa.eu/en/office/aspects/communications/05-03.htm> (status: 30 July 2012). 


\section{Preservation of earlier rights under national law}

Pursuant to Article 165(5) of the CTMR, a proprietor of an earlier national trademark whose registration was secured in good faith and prior to the accession date may prohibit the use of a CTM in the territory of the acceding state. The right to prohibit the use of a CTM on the basis of an earlier national right confirms what is already contained in Articles 110 and 111 of the CTMR. Article 110 reiterates that by acceding to the CTMR, a new Member State does not jeopardise the right existing under its laws pursuant to which claims for infringement of earlier rights recognised under the $\mathrm{CTMR}^{708}$ may be enforced against the use of a later CTM. For its part, Article 111 envisages a scenario in which a national registration affirms validity of earlier rights even where such rights apply only to a particular locality. Where this is a case, the owner of national earlier rights has a right to oppose the use of a CTM in the territory of the acceding state in which his rights enjoy protection. Even where the owner of earlier rights confined to a particular locality can no longer oppose the use of a later CTM because five years within which, pursuant to Article 111(2), he is entitled so to oppose have elapsed, ${ }^{709}$ the CTM proprietor will be allowed to use his CTM in the territory concerned without affecting the rights of the proprietor of the earlier national rights. The territory where the earlier national rights are protected will become a no-man's land, since the CTM proprietor will be able to use his CTM in the territory without prohibiting the use, by the owner, of the earlier national rights identical or similar to a CTM.

\section{Enforcement of Community trade mark rights}

The interrelationship between the CTM system and the national trademark systems of the Member States may, as well, be explained in light of the CTM enforcement regime provided for under the CTMR. The CTMR establishes a legal system devoted solely to the enforcement of CTM rights. ${ }^{710}$ The system, however, depends so much on the various legal systems of the Member States for its effectiveness. It identifies among national institutions of the Member States courts, which are competent to deal with the CTM enforcement issues. Since various laws such as the national law of the Member States or the Brussels

$710 C f$. Title $\mathrm{X}$ of the CTMR. 
Regulation, in addition to the CTMR, have to be applied to CTM infringement suits, the enforcement system lacks sufficient certainty, clarity and predictability.

\section{Application of Brussels Regulation}

Article 94(1) of the CTMR identifies Regulation (EC) No 44/2001 of 22 December 2000 on jurisdiction and the recognition and enforcement of judgments in civil and commercial matters (henceforth the Brussels Regulation) as a key piece of legislation applicable to issues regarding CTM enforcement.

Before the Brussels Regulation came into force, the Convention on Jurisdiction and Enforcement of Judgments in Civil and Commercial Matters, signed at Brussels on 27 September 1968 (as amended severally) (henceforth, the Brussels Convention) applied to CTM enforcement disputes. This was made possible by Article 90 of the Council Regulation No 40/94 of 20 December 1993 on the Community trade mark (before its replacement by Article 94 of Council Regulation (EC) No 207/2009 of 26 February 2009 on the Community trade mark). The consolidated version of the Brussels Convention, published in OJ EC C 27/1998, p. 1, was replaced (except between the EU Member States and Denmark) by the Brussels Regulation. According to paragraph 22 of the preamble to the Brussels Regulation, the Brussels Convention applies to the relationship between the EU Member States and Denmark.

The legislative purpose of Article 94(1) of the CTMR is to ensure that the provisions relating to CTM enforcement contained in the CTMR do not conflict with those contained in the Brussels Regulation. The Article stipulates as follows:

Unless otherwise specified in this Regulation, Regulation (EC) No 44/2001 shall apply to the proceedings relating to Community trade marks and applications for Community trade marks, as well as to proceedings relating to simultaneous and successive actions on the basis of Community trade marks and national trade marks.

Article 94(1) of the CTMR is, therefore, a default rule. Where the CTMR is silent on certain aspects of CTM enforcement, the provisions of the Brussels Regulation have to be applied. To put it tritely, the application of the Brussels Regulation is subject to what is stipulated elsewhere in the CTMR. Thus, the rules enacted at Brussels ${ }^{711}$ are excluded in cases covered by the CTMR's own system. ${ }^{712}$

711 As contained in the Brussels Regulation (EC) No 44/2001 of 22 December 2000.

712 Cf. FAWCETT, J. J. \& TORREMANS, P., "Intellectual Property and Private International Law" 320 (Oxford University Press, Oxford 1998). 
It is important to note that the Brussels Regulation deals with enforcement issues touching on any commercial and civil matters. Since the CTMR enshrines specific provisions regulating CTM enforcement, the legal maxim lex specialis derogat legi generali may be based upon to qualify application of the Brussels Regulation to CTM enforcement. Article 94(2) (a) of the CTMR, for instance, expressly excludes Articles 2, 4 and 5(1), (3) - (5) of the Brussels Regulation from being applied to the CTM disputes.

\section{Community trade mark courts}

Article 95 of the CTMR establishes Community trade mark courts. Pursuant to the provisions of the immediately preceding Article, Member States are directed to designate a limited number of national courts and tribunals of first and second instances to serve as Community trade mark courts. It is considered that designation of limited number of CTM courts may "encourage uniform application of the CTM Regulation and, hence, further promote the uniformity of the CTM system". 713

States which were already EC Members in 1994 when the system established under the CTMR became operational, were thus required to designate the CTM courts in their territories by 14 March 1997 (i.e. within three years after the CTM system came into force). ${ }^{714}$ Since new EU Member States must accept the acquis communautaire of the EU law as it stood on the accession day, it cannot be doubted that these States are as well obliged to nominate few courts within the national court system to serve as CTM courts.

Germany complied with the provisions of Article 95(1) of the CTMR by designating 18 Regional Courts (Landgericht) to serve as CTM courts of first instance and 18 Higher Regional Courts (Oberlandesgericht) to operate as CTM courts of second instance. This designation does not interfere with the powers of the German Federal Patent Court, which enjoys an exclusivity of a mandate to deal with appeals emanating from decisions of the German Patent and Trade Mark Office, for the court deals with the CTM only when it comes to "opposition against registration of a national trademark ... based on a Community trade mark with an older priority". ${ }^{715}$ On its part, the United Kingdom

$713 C f$. FAMMLER, M. \& AIDE, C., "Enforcement of CTM in the EU: the real test of their commercial value", 86 J. Pat. \& Trademark Off. Soc'y 135, 140 (2004).

714 Article 95(2) of the CTMR.

715 Cf. RADEN, L. van, "Community Trademark Courts - German Experience", 34(3) IIC 270 et seq. (2003). 
designated only four courts to serve as CTM courts. The courts are the High Court of England, Wales and Northern Ireland, and the Court of Session of Scotland (in the first instance). The Court of Appeal of England, Wales and Northern Ireland, and the Scottish Court of Appeal are designated for the second instance. $^{716}$

CTM courts would therefore be required to carry out some duties entrusted to them under the CTMR. ${ }^{717}$ The stipulation in the CTMR, pursuant to which Member States have to appoint some national institutions to deal with CTM rights, has been criticised since the use of national language in the proceedings relating to CTM does not necessarily have to be renounced. ${ }^{718}$

National courts of the Member States, other than those expressly designated as the CTM courts, are, under certain circumstances given power to deal with disputes concerning infringement and validity of CTMs. It follows from the wording of Article 95(5) of the CTMR that in the event a Member State concerned does not designate some local courts to serve as CTM courts, the normal national courts with jurisdiction to hear disputes concerning infringement and validity actions of the national trademark rights are given power to hear disputes concerning CTM rights. Indeed, Article 95(5) of the CTMR extends the national court's "jurisdiction ratione loci and ratione materiae in the case of proceedings relating to a national trade mark" to proceedings relating to CTM.

\section{Jurisdiction over infringement and invalidity proceedings}

The CTMR delineates jurisdiction of the CTM courts in relation to CTM disputes. ${ }^{719}$ The term jurisdiction is normally employed to refer to some powers entitling legal authorities, particularly courts of law, to adjudicate over disputes prescribed in the instrument granting the pertinent powers. A response to the question whether a particular court has some powers to deal with a CTM depends on whether a dispute in question relates to infringement, or whether it concerns validity of a CTM. Both alternatives are addressed under Article 96 of the CTMR.

$716 C f$. M. FAMMLER \& C. AIDE, "Enforcement of CTMS in the EU: the real test of their commercial value", 86 J. Pat. \& Trademark Off. Soc'y 135, 140 (2004). Cf. also $<$ http://oami.europa.eu/pdf/mark/ctmcourts_addreses.pdf $>$ (status: 30 July 2012).

717 Cf. Article 95(1) of the CTMR.

$718 C f$. RADEN, L. Van, "Community trademark courts - German Experience", 34(3) IIC 270, 276 (2003).

$719 C f$. Articles 96 to 100 of the CTMR. 
a) Infringement actions

Article 96(a), (b) and (c) of the CTMR establishes competence of CTM courts in relation to various actions. These courts may, for instance, adjudicate on an action concerning infringement of a CTM, or an action the result of which would be a declaratory judgment confirming that the plaintiff does not infringe a particular CTM. Similarly, CTM courts have powers to deal with actions concerning "threatened infringement relating to Community trade mark" ${ }^{720}$ It is important to note that for CTM courts to have powers to deal with actions of threatened infringements or those concerning a declaration of non-infringement, the national law of a Member State in which a respective CTM court is situated must be permissive. ${ }^{721}$ This implies that the CTM courts, being established under the national law on one hand, and being part of the national legal system on the other, have to take account of the national law with the result that in the event of a conflict with the Community law (i.e. the CTMR) such as where the national law ousts jurisdiction of the national courts in respect of certain aspects of CTM enforcement, the national law will prevail over the Community law granting powers in respect of those aspects.

EU jurisprudence confirms that an application for a CTM registration confers a property right even before such an application matures to registration. Article 9(3) of the CTMR reiterates this position. It provides that "Reasonable compensation may... be claimed in respect of matters arising after the date of publication of a Community trade mark application, which matters would, after publication of the registration of the trade mark, be prohibited by virtue of that publication". Analogous to this reality, is the legal position stipulated under Article 96(c) of the CTMR, which empowers a CTM court to adjudicate on some conflicts arising out of the use by third parties of a plaintiff's sign, while the said sign was a subject of a CTM application at the time when the defendant applied the sign to his goods. While there is nothing in the CTMR to prohibit the CTM courts from dealing with infringing use of a sign which is a subject of a published CTM application, the courts have unhampered liberty to defer such actions to a future date after a registration certificate is issued. ${ }^{722}$

$722 C f$. Article 9(3) of the CTMR, last sentence. 
b) Validity of a Community trade mark

OHIM and CTM courts enjoy concurrent competence to deal with CTM revocation and invalidity proceedings. Where the actions relating to revocation and declaration of invalidity of a CTM have not yet been raised before the CTM courts by way of counterclaim, OHIM has an exclusive jurisdiction to determine the fate of a CTM insofar as the counterclaim is concerned. ${ }^{723}$ OHIM's decision on a counterclaim has a res judicata effect. Where OHIM determines a dispute relating to revocation or a declaration of invalidity of a CTM, finally and conclusively, the counterclaim in relation to the same issues as determined by OHIM and in relation to the same parties may not be pleaded successfully in an infringement action before the CTM courts. ${ }^{724}$

The CTM courts cannot deal with revocation or invalidity proceeding suo $m o t u$. They must, while dealing with infringement suits, proceed on an assumption that a registered CTM is valid. ${ }^{725}$ Presumption of CTM validity is nonetheless rebuttable. A defendant may, in an infringement action, plead a defence of counter claim putting a validity of a CTM concerned in issue. ${ }^{726}$ In this scenario, a CTM court seized of the matter, by virtue of Article 96(d) of the CTMR, must conduct a trial within a trial - a stance which may lead to a declaration of invalidity (or confirmation of validity), or revocation of the CTM rights concerned. However, where the CTM proprietor requests, a CTM court may, as an option, decide not to conduct the "trial within a trial", and, instead, stay the main proceedings with the order being given to the defendant requiring him to submit his counterclaim to OHIM. The court will, however, be waiting for the outcome of the counterclaim to proceed with the infringement action. If the defendant does not take the counterclaim to OHIM, the CTM court will deem such a claim to have been withdrawn. ${ }^{727}$

\section{International jurisdiction}

Article 97 of the CMR, which describes international jurisdiction of CTM courts, determines jurisdiction based on three main factors, namely, a close connection

$723 C f$. Article 51 to 53 of the CTMR.

724 Cf. Article 100(2) of the CTMR.

$725 C f$. Article $99(1)$ of the CTMR.

726 "The validity of a Community trade mark may not be put in issue in an action for a declaration of non-infringement" ( $c f$. Article 99(2) of the CTMR).

727 $C f$. Article 100(7) of the CTMR. 
of the parties and the courts, the factors contained in the Brussels Regulation, and a place where a harmful act takes place.

\section{a) Connection of parties and courts}

Article 97 (1) to (3) of the CTMR devises a certain logical approach to the question of jurisdiction, by granting powers to the CTM courts on account of domicile or establishment of the defendant or the plaintiff. Where these two elements cannot be traced in the EU, a CTM court of general jurisdiction has to be identified. The following checklist is instrumental for the determination of international jurisdiction stipulated in the above provisions:

- Is the defendant's place of domicile traceable in one of the Member States? If the answer is in the affirmative, then the CTM court of the Member State concerned will have powers to determine the dispute in issue (cf. Article 97(1)).

- If the answer to the above question is in the negative, the question whether a defendant is commercially established in one of the Member States has to be determined. If it is found that the defendant is established in the EU, the CTM court in the Member State where the defendant is established have power to deal with a dispute in issue (cf. Article 97(1)).

- If it appears that the defendant is neither domiciled nor established in the EU, the place of domicile or the place of establishment of the plaintiff will be decisive as to the CTM courts with jurisdiction to litigate on issues concerning a CTM. The result here will be that the CTM courts of the Member State in which the plaintiff is domiciled or established will have powers to deal with a CTM by virtue of that domicile or establishment (cf. Article 97(2)).

- Suppose that both the defendant and the plaintiff have neither their domicile nor establishment in the EU. The CTM courts of Spain (which have general international jurisdiction by virtue of the fact that Spain is the Member State in which OHIM has its seat) will have powers to deal with any action relating to a CTM (cf. Article 97(3)). 
It should be noted that the above checklist must be observed strictly and consecutively. ${ }^{728}$

b) Factors contained in the Brussels Regulation

Article 97(4) of the CTMR provides a special category of jurisdiction to a CTM court which, pursuant to the checklist in (i) above, would not have jurisdiction to deal with a dispute concerning a CTM, but for the agreement reached between the parties; ${ }^{729}$ or, because the defendant has entered an "appearance before a different Community trade mark court" ${ }^{730}$ In essence, Article 97(4) provides a supplemental jurisdiction to CTM courts. It states clearly that the provisions of Articles 23 and 24 of the Brussels Regulation may be taken into account to determine a court with competence to deal with CTM suits.

The following checklist, which is based on the provisions of Articles 23 and 24 of the Brussels Regulation, may aid a CTM court to establish whether it is competent to deal with a dispute relating to CTM infringement:

- Have the parties to the suit concluded an agreement indicating their preference as to a suitable forum to deal with the dispute? If the answer is 'yes', then this forum has a full legal mandate to deal with a dispute.

- Is there any forum which may constructively be deemed as a place of domicile of the defendant so as to confer jurisdiction on the CTM courts of this forum? Article 24 of the Brussels Regulation, may be applied to confer jurisdiction on the courts before which a defendant enters an appearance. However, a note of caution looms high here: the rule laid down in Article 24 cannot be relied upon to confer jurisdiction on a court if the defendant entered appearance solely to contest jurisdiction of the said court.

As an advantage of the party autonomy enshrined in Article 23 of the Brussels Regulation, litigants are able to "avoid the compartmentalization of the dispute

$728 C f$. JENKINS, N., "Litigation: Jurisdiction and procedure" in: POULTER, A., BROWNLOW, P. \& GYNGELL, J. (eds.), "the Community Trade Mark: Regulations, Practice and Procedure" (2nd ed., Release \#4) XI.5 (INTA, New York 2005).

729 Cf. Article 77(4) (a) of the CTMR.

730 Article 97(4) (b) of the CTMR. 
in many legal systems" and hence, the possibility to "foresee the applicable law". ${ }^{731}$

c) Place where harmful act takes place

Article 97(5) of the CTMR provides an alternative approach to the question of a court with jurisdiction to deal with disputes concerning CTMs. Pursuant to this provision, an infringement suit may be brought in a forum in which a harmful act takes place, irrespective of whether the defendant or the plaintiff is domiciled or established in the forum. However, this source of jurisdiction, entitles the CTM courts of the forum where an infringement takes place to deal only with the suits concerning actions described under Article 96 of the CTMR, ${ }^{732}$ but subject to the exception stipulated under Article 97(5) of the CTMR. According to this exception, the court which assumes jurisdiction by virtue of Article 97(5) has no power to deal with "actions for a declaration of non-infringement of a Community trade mark".

\section{Delimitation of jurisdiction}

Article 98 of the CTMR distinguishes the powers of the courts having jurisdiction by virtue of Article 97 (1) to (4), and those of the courts having jurisdiction to deal with CTM disputes based on Article 97(5). If the CTM court finds that it has jurisdiction based on the sole fact that the harmful act has taken place in its own territory in accordance with Article 97(5), its competence will be limited to the events of infringement or to acts of threats of infringement committed in that territory only. ${ }^{733}$

However, a different result might be confirmed if the CTM court decides that it has jurisdiction on the basis of Article 97(1) to (4). ${ }^{734}$ The extent of jurisdiction is not limited to the events of infringements or acts of threat of infringement of a registered CTM or in respect of a sign whose application for registration is already published that take place in the country where the said CTM court is

731 PERTEGAS, M., "Intellectual property and choice of law rules", in: MALATESTA, A. (ed.), "The unification of choice of law rules on torts and other non-contractual obligations in Europe" 236 (CEDAM, Padova/Milan 2006).

732 Cf. Section D (II)(1)(a) of this chapter.

$733 C f$. Article 98(2) of the CTMR.

734 See section D (II)(2)(a) \& (b) of this chapter. 
situated. These courts have a mandate under Article 98(1) to deal with any infringement acts, which take place in any EU Member State. It follows naturally that an action can be brought before a German court, where the defendant is domiciled or established, in respect of an act of infringement committed in England.

\section{Related, simultaneous and successive actions}

The courts dealing with trademark disputes are required under the law ${ }^{735}$ to decline their power to deal with the disputes arising out of claims, which are related. Thus, "actions are deemed to be related where they are so closely connected that it is expedient to hear and determine them together to avoid the risk of irreconcilable judgments resulting from separate proceedings". ${ }^{736}$ This may happen in two scenarios, namely, where only the CTM rights are in issue, or where the CTM rights and the national rights are in question, given that the CTM and the national trademark both are similar, owned by a single person and used in relation to similar/identical goods and/or services.

\section{a) Similar Community trade mark claims}

When it comes to specific claims regarding CTM infringement, Article 104 of the CTMR, stipulates the conditions which must be fulfilled before a CTM court is obliged to renounce its jurisdiction. The Article reads as follows:

A Community trade mark court hearing an action referred to in Article 96, other than an action for a declaration of non-infringement shall, unless there are special grounds for continuing the hearing, of its own motion after hearing the parties or at the request of one of the parties and after hearing the parties, stay the proceedings where the validity of the

Community trade mark is already in issue before another Community trade mark court... ${ }^{737}$

CTM courts and OHIM work closely. For instance, OHIM is also required to stay proceedings relating to revocation or declaration of invalidity, if these issues are already before a CTM court, being brought there by way of a counter-claim defence. $^{738}$ However, the fact that the CTM court is obliged to stay the

$735 C f$. Articles 27 and 28 of the Brussels Regulation, as well as Articles 104 and 109 of the CTMR.

736 Article 28(3) of the Brussels Regulation.

737 Article 104(1) of the CTMR.

738 Article 104(2) of the CTMR. 
proceedings does not mean that the court is barred from ordering "provisional protective measures for the duration of the stay". ${ }^{739}$

Article 104 of the CTMR takes the cause of legal certainty by reinforcing the idea that favours avoidance of contradictory judgments and unfounded legal proceedings. Nevertheless, the provisions of Article 104 of the CTMR do not apply in relation to a declaration of non-infringement. The provisions only apply in respect of counterclaim, which might have effects of revoking, or which might lead to the declaration of invalidity of, the rights concerned.

\section{b) Related Community trade mark and national trademark claims}

Article 109 of the CTMR describes some instances under which simultaneous and successive actions based on a CTM or national trademarks may oblige a CTM court to decline its own jurisdiction in favour of another CTM court first seized of the matter. Article 109(1) for instance, proceeds on hypothetical facts reflecting a scenario under which simultaneous proceedings are brought before courts of two different Member States. While the infringement claims brought before one of the courts is based on a CTM, the other claim is based on a national trademark. For the rule under Article 109(1) of the CTMR to apply, two alternative questions must be answered in affirmative: ${ }^{740}$ (a) Do the CTM and the national trademark concerned fulfil the "triple-identity" rule? The question seeks to determine whether the marks and the goods or services and the owners are the same. (b) Are the CTM and the national trademark concerned identical and protected for similar goods or service? If no, are the CTM and the national trademark concerned similar and protected for identical goods or services?

An affirmative response to question (a) will mean that the "court other than the court first seized shall of its own motion decline jurisdiction in favour of that court" and where the jurisdiction of the court first seized of the matter is challenged, the other court may stay its proceedings pending determination of the jurisdictional question. The positive response to question (b) will mean that the court other than the one first seized of the matter will not be obliged to decline its jurisdiction, but may deem it wise to stay the proceedings.

Interpretation of Articles 27 and 28 of the Brussels Regulation may also serve as guidance for the interpretation of Article 109 (1) (a) \& (b) of CTMR. Article 27 leads to a conclusion that jurisdiction is to be declined even where the CTM court first seized of the matter has not yet determined its jurisdiction. As a matter 
of principle, the courts second seized of the matter cannot determine their jurisdiction, unless the court first seized has already determined that it has no power to deal with the suit. The matter becomes more complicated as a list of various courts which might have declined their jurisdictions, by paying patronage to this rule, have to be established according to a cascading order, with the consequence that each court has to determine whether it has jurisdiction upon a negative conclusion regarding the jurisdiction by the court first seized of the matter. This likelihood raises a cause for concern given that whilst courts are busy determining their jurisdiction, an abeyance of proceedings will not be avoided. If several courts are required to decide, consecutively, on jurisdictional issues (as explained above), the enforcement system established under the CTMR cannot avoid criticisms for it condones dilatory measures, to an extent which could eventually jeopardise the attractiveness of the Community trade mark.

Article 28 deals with the situation where the court first seized of the dispute has already established its jurisdiction and is already considering the claim, under which event this court should be left alone to deal with matter.

On the other hand, successive actions - one based on the CTM and another based on the national trademark and vice versa - may trigger a court hearing an infringement suit to reject the second claim. ${ }^{741}$ The scenario, which is reflected under Article 109(2) \& (3) of the CTMR describes the reality that a proprietor of a CTM and of a corresponding national trademark registration may seek to sanction infringement of trademark either by (a) suing in the national court for infringement of the national trademark corresponding to the CTM, or by (b) suing for the infringement of the CTM corresponding to the national trademark.

If, pursuant to alternative (a) the court dealing with the matter has finally and conclusively pronounced a judgment on merits of the case, such a decision has a res judicata effect with respect to any claim that would be brought before the court by the proprietor in respect of infringement perpetuated by the same defendant. It is no defence for a plaintiff to plead that the judgment on merits serving as a res judicata was in respect of an infringement of a national trademark and that the current claim is based on an infringement of a CTM. The overriding point, which guides the court in rejecting the claim, is the fact that the national trademark and the CTM are actually the same, falling under a single ownership. Alternative (b) means the opposite of alternative (a). Here the claim already determined on merits was based on a CTM infringement, which will

741 Cf. FAWCETT, J. J. \& TORREMANS, P., "Intellectual Property and Private International Law” 338 (Oxford Univ. Press, Oxford 1998). 
serve as a res judicata against filing a claim regarding the same infringement, but this time based on the national trademark.

Article 109(2) \& (3) does not envisage a situation where the infringement suits are instituted concurrently, for if this were the case, then the situation depicted in the provision would hardly happen since the court would be required to decline its own jurisdiction in favour of the court first seized of the matter as per Article 109(1). What must be made clear is that the provisions of Article 109(2) \& (3) equate claims arising out of an infringement of national trademark and a CTM as a single claim and thus restricting splitting a single claim into two. This is essentially a recognition and practical application of the principle of "res judicata". Recognition of the principle under the enforcement system established under the CTMR removes in part the likelihood of having conflicting decisions since several courts may have jurisdiction to try similar or one and the same claim. On the other hand, such recognition confirms that even if the enforcement mechanism established under the CTMR subjects itself to the jurisdiction of various courts, those courts are regarded as one and same court - a fact which reaffirms the unitary characteristics of a registered CTM.

\section{5) Jurisdiction to award temporary reliefs}

The CTMR, in its Article 103, uses the phrase "provisional and protective measures" to refer to the term "temporary relief". The phrase "provisional, including protective, measures" within the meaning of Article 103(1) of the CTMR is regarded to refer to measures which, in matters within the scope of the CTMR, "are intended to preserve a factual or legal situation so as to safeguard rights the recognition of which is otherwise sought from the court having jurisdiction as to the substance of the case". ${ }^{742}$

Both the national courts and the CTM courts have concurrent jurisdiction to grant "provisional, including protective, measures in respect of a Community trade mark or a Community trade mark application as may be available under the law of that state in respect of a national trade mark". The courts' power to grant temporary relief cannot be assailed solely on the ground that a CTM court of another Member State has a jurisdiction to deal with the substance of the matter. $^{743}$

742 Cf. Case C-391/95 van Uden Maritime [1998] ECR I-07091, para. 37. Cf. also Case C261/90 Mario Reichert v Dresdner Bank AG [1992] ECR I-02149, para. 34.

743 Cf. Article 103(1) of the CTMR. 
While an agreement between the parties can exclude jurisdiction of the courts, which seek to determine the suits finally and conclusively, courts' power to grant temporary relief is an inherent mandate which cannot be ousted by an agreement since, where granted, a temporary relief does not determine the matter finally and conclusively. ${ }^{744}$

However, Article 103(2) of the CTMR delimits the extent of the effects of the temporary reliefs that may be granted pursuant to Article 103(1) of the CTMR. Consequently, the decisive factor as to whether a court considering granting the provisional and/or protective measure has power to grant the corresponding relief with effects beyond the Member State in which the court has its seat, depends on whether the said court has jurisdiction to deal with the matter based on the establishment or domicile of the defendant or the plaintiff. ${ }^{745}$ If the court's source of jurisdiction is other than the foregoing, ${ }^{746}$ then the resulting order will have effects only to the scale of a single Member State where the court issuing such an order is situated.

\section{Applicable law}

\section{Rome II Regulation}

The general choice of law rule in intellectual property infringement actions in Europe is contained in Article 8 of Regulation (EC) No 864/2007 of the European Parliament and of the Council of 11 July 2007 on the law applicable to non-contractual obligations (henceforth, Rome II) ${ }^{747}$ According to the Article "the law applicable to a non-contractual obligation arising from an infringement of an intellectual property right shall be the law of the country for which protection is claimed". ${ }^{748}$ The Article provides further that "in the case of a noncontractual obligation arising from an infringement of a unitary Community intellectual property right, the law applicable shall, for any question that is not

744 Cf. Case C-391/95 van Uden Maritime [1998] ECR I-07091, para. 48.

745 It must be recalled that constructive domicile or establishment of the parties can be inferred where the parties concerned enter into an agreement requiring them to submit their dispute to the courts of the country stipulated in the agreement, or where the defendant voluntarily submits himself before the courts of a Member State. See in this respect, section D (II) (2) (a) and (c) of this chapter.

746 Such as where the jurisdiction is based on Article 97(5) of the CTMR, i.e., the place where an act of infringement or an act of threatening infringement takes place.

747 According to its Article 32, Rome II entered into force on 11 January 2009 in respect of all provisions except Article 29, which entered into force on 11 July 2008.

748 Article 8(1) of Rome II. 
governed by the relevant Community instrument, be the law of the country in which the act of infringement was committed". ${ }^{749}$

Article 8(1) of Rome II, therefore, adapts the lex loci protectionis rule to the enforcement of national intellectual property rights. To put it in the context of national trademark rights, the Article implies that the law of the Member State where the relevant rights are protected will determine the conditions for trademark protection and the law to be applied to the trademark enforcement. ${ }^{750}$ This conclusion enforces the principle of territoriality of intellectual property, trademark rights in particular, according to which, trademarks can only be valid in the territory of the state for which they are granted. ${ }^{751}$

In spite of its unitary character, it is tenable to submit that the CTM can also benefit from the lex loci protectionis rule. ${ }^{752}$ It may certainly be argued that the CTM rights "are not infringed in the Community but rather in the Member States of the Community, and cannot be enforced in the Community but only in the Member States". ${ }^{753}$

To the extent that Article 8(2) of Rome II recognises national law of the Member State as a substantive law applicable to enforcement of Community intellectual property rights, which are not governed by the relevant Community instruments, it supplements the enforcement provisions of the CTMR as the discussion below under section $\mathrm{D}(\mathrm{III})(2)(\mathrm{c})$ of this chapter depicts.

\section{Community Trade Mark Regulation}

a) General applicable law

Article 14 of the CTMR entrusts regulation of the effects of CTM rights to the provisions of the CTMR alone. According to a declaration contained in the Article, CTM courts have to apply to CTMs procedural law and infringement law the same law that applies to national trademarks. Article 14 of the CTMR

749 Article 8(2) of Rome II.

750 Cf. ECJ, Case C-9/93 IHT Internationale Heiztechnik GmbH v Ideal Standards GmbH [1994] ECR I-02789, para. 2 of the summary of the judgment.

751 LUNDSTEDT, L., "Jurisdiction and the Principle of Territoriality in Intellectual Property Law: Has the pendulum swung too far in the other direction?", 32(2) IIC 124 (2001).

752 Article 8(2) of Rome II confirms this conclusion.

$753 C f$. KNAAK, R., "The legal enforcement of the Community trademark and prior national rights", 29(7) IIC 754 (1998). 
does not, however, give a clear picture as to whether it is the national law or the CTMR that has a primacy over the other.

Certainly, CTMR must be identified as the law applicable to the protection of the rights established under it. Article 101 of CTMR establishes a set of norms which are applicable to disputes concerning CTM rights. While the CTM courts are required to apply the provisions of CTMR as a primary law governing issues relating to CTMs, where CTMR is silent on certain aspects the courts are given mandate to apply not only the law of the country in which the court is established but also the private international law of this Member State. ${ }^{754}$ Furthermore, in the event CTMR does not provide to the contrary, a CTM court is required to resort to the "rules of procedure governing the same type of action relating to a national trade mark in the Member State where it has its seat". 755

The fact that Article 101 of CTMR creates a pointer to the national laws of the Member States means that these laws are (in addition to the CTMR) the lex loci protectionis, which may be applied to determine a fate of CTM rights. ${ }^{756}$ Article 101(2) of the CTMR does not identify one specific set of national laws, as it also makes reference to private international law of the country where the CTM court, before which infringement claim is instituted, is situated.

b) The law applicable to sanctions

The practical application of Article 101 of CTMR described above can be demonstrated by a discourse on Article 102 of CTMR which identifies the law applicable to sanctions. Article 102(1) alone may suffice to indicate how CTMR and the national law may be applied simultaneously. The provision allows a CTM court to issue a perpetual injunction based on CTMR, with a possibility of resorting to the rules of national law if that would be an efficient way of making the injunction enforceable in the country where the CTM court is situated. Indeed, CTM courts are obliged to grant injunctive relief "unless there are circumstances specific to the case which would allow a conclusion that further infringements will not occur". ${ }^{757}$ Civil imprisonment or a penalty may be regarded as some of the measures the CTM court may undertake pursuant to the

754 Article 101(1) \& (2) of the CTMR.

$755 C f$. Article 101(3) of the CTMR.

$756 C f$. See section D (III) (1) of this chapter for the justification of the application of lex loci protectionis rule to the CTM enforcement.

$757 C f$. MÜHLENDAHL, A., "Enforcement of Intellectual Property Rights - Is Injunctive Relief Mandatory?” 38(4) IIC 377, 380 (2007). 
law of a Member State concerned. ${ }^{758}$ Any measures which the CTM court opts for, must ensure that the injunction is complied with "even if the national law includes a general prohibition of infringement of Community trade marks and provides for the possibility of penalising further infringement or threatened infringement, whether intentional or due to gross negligence". ${ }^{759}$ It follows therefore that, the measures to be taken by the CTM courts within the meaning of Article 102(1) of CTMR, should ensure compliance with the injunction even where the said measures could not, pursuant to the national law, be taken "in the case of corresponding infringement of a national trade mark" ${ }^{760}$

The foregoing conclusion is in line with the provisions of the enforcement directive, ${ }^{761}$ which harmonises the means of enforcing intellectual property rights, such as "the arrangements for applying provisional measures, which are used to preserve evidence, the calculation of damages, or the arrangements for applying injunctions". ${ }^{762}$ Article 3 of the directive provides that:

Member States shall provide for the measures, procedures and remedies necessary to ensure the enforcement of the intellectual property rights... Those measures, procedures and remedies shall be fair and equitable and shall not be unnecessarily complicated or costly, or entail unnecessary time-limits or unwarranted delays. ${ }^{763}$

On its part, Article 102(2) tries to capture all conceivable aspects of enforcement other than by way of permanent injunctions. The Article identifies the law applicable to infringement aspects or aspects of threat of infringement to be the law of the country where the "acts of infringement or threatened infringement were committed, including the private international law".

\section{c) Efficacy of lex loci delicti rule}

To a passive observer, the legislative techniques employed under Article 102 would seem a perfect solution to the CTM enforcement since infringements are likely to be perpetuated in some demarcated, territorial precincts where the lex

758 KOOIJ, P.A.C.E. van der, "The Community Trade Mark Regulation: An Article by Article Guide" 166 (Sweet \& Maxwell, London 2000).

759 ECJ, Case C-316/05, Nokia Corp. v Joacim Wärdell [2006] ECR I-12083, para. 3 of the operative part.

760 ECJ, Case C-316/05, Nokia Corp. v Joacim Wärdell [2006] ECR I-12083, para. 4 of the operative part.

761 Directive 2004/48/EC of the European Parliament and of the Council of 29 April 2004 on the enforcement of intellectual property rights, contained in $O J L 195,2.6 .2004, p$. $16-25$.

$762 C f$. Paragraph 7 of the preamble to the enforcement directive.

763 Article 3(1) of the enforcement directive. 
loci protectionis sufficiently provides a remedy. And, indeed, the rule laid down in Article 8(2) of Rome II does not conflict with Article 102(2) of CTMR, since the former Article confirms, more precisely, what is already contained in the latter. While Article 102(2) refers to the law of the Member State where infringing act takes place including the private international law of this State, Article 8(2) of Rome II refers only to the general law of the Member State where incidence of infringement takes place. This reference in Rome II implicitly extends to private international law of the Member State concerned, for it is a national law which determines a country's private international law. However, a critical, legal analyst cannot take it for granted that the rules laid down in the above Articles do not lead to any irreconcilable legal implications.

The fact that the law of the Member State is applicable to a CTM if the act infringing the CTM concerned is carried out in this Member State, means that the law of this particular Member State becomes lex loci protectionis. Thus, all CTM courts in the EU will be forced to apply this lex loci protectionis. This cannot pose any legal problem if the infringement takes place only in one country. However, neither CTMR nor Rome II has provided a proper solution in case several infringing acts are traced in different Member States. In the latter scenario, a CTM court will find itself obliged to apply laws of different Member States to a single infringement suit.

\section{Recognition and enforcement of Judgments}

There is no provision in CTMR dealing with the recognition and enforcement of judgments issued by the courts with competence to deal with disputes arising out of exploitation of a CTM. However, the Brussels Regulation is applicable based on the general reference in Article 94 of CTMR. Article 33(1) of the Brussels Regulation directs the EU Member States to acknowledge and enforce judgments issued in any Member State. ${ }^{764}$

In some instances, however, a judgment for the enforcement of a CTM issued by a court in one Member state may not be recognised in other Member States. This would be the case, for example, if by recognising such a judgment the institutions concerned would be in breach of the odre public, which must be observed in the Member State concerned. ${ }^{765}$ More the same, an ex-parte judgment issued against a defendant who can justify his non-appearance, before

$764 C f$. WURTENBERGER, G., "Enforcement of Community Trade Mark Rights", 4 I.P.Q. 402, 412 (2002).

$765 C f$. Article 34 of the Brussels Regulation. 
the court, to take part in the proceedings which culminated in the judgment sought to be enforced may be disregarded by the authorities in the country where enforcement is sought. As a valid ground for opposing enforcement of a foreign, ex-parte judgment, the judgment debtor may adduce evidence revealing the fact that he was not served with the plaint in sufficient time, hence was not able to arrange for his defence. However, the court of the Member State in which enforcement of the judgment is sought will have to inquire into the veracity of the defendant's averment, since if it is obvious that the defendant had an opportunity to challenge the judgment ${ }^{766}$ but did not do so in time, the opposition against recognition and enforcement cannot be successful. ${ }^{767}$ The opposition against recognition and enforcement would be successful if the judgment debtor is smart enough to prove that the foreign judgment conflicts with a judgment issued, between the same parties and the same cause of action, by a court in the territory where enforcement is sought. ${ }^{768}$

The judgment debtor would, nevertheless, achieve the same results as above, if he can substantiate the fact that the foreign judgment conflicts with another judgment between the same parties issued by a court in another Member State or another third country. However, rejection of enforcement of the latter judgment irreconcilable with the former depends on whether the former judgment has already been enforced in the Member State where such enforcement was requested. If the former judgment has not yet been enforced, the law of the Member State where enforcement is (or would be) preferred has to be examined to find out whether the enforcement of the former judgment is (or would be) permissible. $^{769}$

It should, however, be noted that the findings contained in a foreign judgment, which is a subject of recognition and enforcement proceedings in another EU Member States, are sanctity. Thus, the judgment debtor cannot challenge the substance of a foreign judgment, ${ }^{770}$ nor can he ask the court in the Member State where enforcement is sought to vary the facts on which the court of the Member State of origin based its jurisdiction ${ }^{771}$ since the court in the country of

766 Three common ways to challenge a judgment may be identified: (1) review (i.e. a court considering its own judgment/decision), (2) revision (a superior court in the hierarchy considering the appropriateness of a judgment by the lower court without issuing a judgment but directing the lower court to deal with a judgment in a certain specified way), and (3) appeal (a superior court considers an application to challenge a decision of the lower court and issues a judgment on merits of the appeal).

$767 C f$. Article 34(2) of the Brussels Regulation.

768 Article 34(3) of the Brussels Regulation.

769 Article 34(4) of the Brussels Regulation.

770 Article 36 of the Brussels Regulation.

771 Article 35(2) of the Brussels Regulation. 
enforcement has no power to review the jurisdiction of the court issuing a foreign judgment, with the consequence that the odre public, as a ground to exclude recognition and enforcement of judgment, may not be relied upon to challenge the jurisdiction of the court of the Member State of origin. ${ }^{772}$

\section{E. Concluding remarks}

The discussion in this chapter reveals that the establishment of the European Community trade mark system required a somewhat complicated legal formula in order to achieve a viable interplay between this newly established unitary right and the different national trade mark rights created and protected in the Member States. While the devised formula enables trade mark proprietors in the EU to own both national and CTM registrations in respect of one and same sign, it also gives them a liberty to switch from the national-based protection regime to the CTM regime and vice versa if they wish to have national registration being integrated in CTM registration or vice versa, provided both national and CTM registrations concern the same mark owned by the same person and registered for identical or similar goods. In view of this aspect of the formula, it is certain that seniority right and the right of a trade mark conversion will continue to be of paramount importance as long as the national trade marks and CTMs still coexist.

While the devised formula deserves compliments for its tactical approach to the complicated question of enforcement of CTM rights, the formula renders the enforcement mechanism less predictable since various national laws must be interpreted by national authorities, each in its own jurisdiction, in relation to CTM infringement. Thanks to the Rome II Regulation which, to a certain extent, clears the ambiguity by pointing directly to the law of the country where respective rights are protected and where infringement takes place as the law applicable to enforcement of industrial property. The CTM enforcement mechanism may be even better if the EU could introduce a regulation on intellectual property enforcement in addition to the EU's enforcement directive which is already at work to harmonise national measures regarding enforcement of industrial property rights. 


\section{Chapter 6: Free movement of branded goods in the European Union}

\section{A. Introduction}

This chapter examines the balance achieved by the ECJ and the $\mathrm{EC}^{773}$ legislature to ensure that trade-mark rights are not used to compartmentalise the EU Common Market into different national markets. In this regard, the Chapter addresses some fundamental principles, which determine the precincts of a trade mark monopoly, namely, the existence-exercise dichotomy, the specific subjectmatter and essential function of trade marks, as well as the principle of exhaustion of trade-mark rights. The chapter explores further various practical instances that clarify the doctrine of exhaustion. Some preliminary considerations in the Chapter are directed to provisions of the Treaty on the Functioning of the European Union (TFEU), which stipulate the principle of free movement of goods.

The central thesis of this chapter is that the principle of free movement of goods in the EU Common Market is not an absolute, but a qualified freedom, as it accommodates some concessions which are necessary to ensure that trade mark proprietors enjoy the monopoly in a way that does not distort competition in the internal market. In this regard, the Chapter reinforces a legal position that the "capacity of a trade mark proprietor to oppose the marketing of products by an importer, where they have been placed on the market in the Member State of export by him or with his consent is regarded as justified, unless it is established, in particular, that such opposition contributes to the artificial partitioning of the markets between Member States". ${ }^{774}$

773 Throughout this Chapter the terms EC (i.e. European Community), EU (i.e. European Union) and EEA (i.e. European Economic Area) are used interchangeably to refer to the geographical area to the scale of which the Community trade mark directive and the CTMR, as well as the Treaty on the Functioning of the European Union (TFEU) are applicable.

774 ECJ, Case C-379/97 Pharmacia \& Upjohn SA v Paranova A/S [1999] ECR I-0692, para. 72 of summary of the judgment. 


\section{B. Legal basis for free movement of branded goods}

\section{The Treaty on the Functioning of the European Union}

The interplay between intellectual property and free movement of goods in the European Union (EU) is regulated under Articles 34 to 36 and 345 of the TFEU. ${ }^{775}$ The use of intellectual property rights to prohibit free movement of goods constitutes a measure having equivalent effects within the meaning of Article 34 of the TFEU. The Article provides that "Quantitative restrictions" on imports and all measures having equivalent effect shall be prohibited between Member States". For its part, Article 36 of the TFEU manifests recognition by the EU legislature of the significant role of industrial property rights in a free market economy "despite their inherent potential to undermine the E.U. free trade objective". ${ }^{777}$ It stipulates that "The provisions of Articles 34 shall not preclude prohibitions or restrictions on imports... or goods in transit justified on grounds of ... the protection of industrial and commercial property". However, the reliance on intellectual property rights to prohibit free movement of goods may be justified only to the extent such use does not constitute a "means of arbitrary discrimination or a disguised restriction on trade between Member States" - a requirement stipulated in the proviso to Article 34 of the TFEU.

The term "disguised restriction on trade between Member States", as expressed in recent ECJ's case law, refers to a scenario in which a trade mark proprietor devises a scheme enabling him to artificially partition the market between the EU Member States. For instance, the proprietor will be regarded as embarking on artificial partitioning of the EC Common Market when, with deliberate intention to segment the market, he relies on a national law, or contractual arrangements, to prohibit imports of similar goods bearing his trade mark that were legally marketed in another Member State. ${ }^{778}$ The ECJ's use of the term "artificial partitioning" presupposes existence of "natural partitioning". It follows from the principles laid down in Article $36 \mathrm{TFEU}$, that the proprietor of a trade mark is naturally allowed to rely on his trade mark rights as owner to oppose the marketing of the branded goods "when such action is justified by the

775 The consolidated version of the TFEU was published in the Official Journal of the European Union No. C 115/47 of 9.5.2008.

776 Quantitative restrictions encompass "measures which amount to a total or partial restraint of, according to the circumstances, imports, exports or goods in transit" ( $c f$. ECJ, Case C-2/73 Gedo v Ente Nazionale Risi [1973] ECR 865, para. 7).

$777 C f$. GROSS, N., "Trade mark exhaustion: the U.K. perspective", 23(5) E. I. P. R. 224, $226(2001)$.

778 ECJ, joined cases C-414/99 to 416/99, Zino Davidoff [2001] ECR I-0869, para. 45. 
need to safeguard the essential function of the trade mark", in which case the resultant partitioning could not be regarded as artificial. ${ }^{779}$

The essential function of intellectual property rights is one of the principles developed by the ECJ in the course of interpreting provisions of the EU law in relation to the free movement of branded goods. It was preceded by the principle that requires a distinction to be made between the existence and exercise of intellectual property rights, and the principle of specific subject-matter of intellectual property rights.

\section{Principles developed by the ECJ}

\section{Existence and exercise of intellectual property}

The principle that requires a distinction to be made between the existence and exercise of intellectual property rights was expounded by the ECJ as a response to a fundamental question of how to achieve a balance between the legitimate interests of right holders to enjoy a monopoly in respect of industrial property protected under the national law and the EU's objective to maintain undivided common market. This question becomes of paramount importance when the owner of a national industrial property seeks to enjoy his rights in a way that clashes with interests of the EU's Common Market, namely the principle of free movement of goods. A partial solution to this question can be found in Article 36 of the TFEU, which disqualifies any attempt, by individuals, to rely on intellectual property to hamper free movement of goods, especially where such reliance disguisedly restricts trade between Member States. However, Article 345 of the TFEU, which provides that the Treaty "shall in no way prejudice the rules in Member States governing the system of property ownership", is a very antithesis of the foregoing conclusion. In the light of this Article, the TFEU seems to subordinate the EU law governing ownership of intellectual property to national law of the Member States regulating the same subject. This begs the question whether the proviso to Article 36 of the TFEU outlaws the use of national industrial property adjudged to be a disguised restriction on trade between Member States.

The provisions of Article 345 and the first part of Article 36 of the TFEU ostensibly trigger individuals in the EU Member States to assume that their nationally protected copyrights, patents, trade marks and other forms of 
intellectual property are sacrosanct rights, unassailable on the basis of Community law, but "left to the authority and control of the Member States". ${ }^{780}$ Nevertheless, in view of some ECJ's judgments, such as Grundig, ${ }^{781}$ Parke, ${ }^{782}$ Sirena, ${ }^{783}$ and Deutsche Grammophon, ${ }^{784}$ this assumption would be treated as a clear misconception of the relationship between Community law and the laws of the Member States. Insofar as this relationship is concerned, these cases offer a two-level approach:

- The court seized of the matter must acknowledge that the existence of intellectual property rights protected in the Member States is a matter of national legislation of a Member State concerned and abstain from questioning such existence on the basis of the Community law.

- The same court must thus employ a legal fiction to isolate existence from exercise of intellectual property rights so that whenever the exercise of intellectual property right comes into conflict with the Community law, such exercise shall be declared illegal without affecting existence of the respective rights under the national law.

As the discussion below elaborates, the above cases were basically decided based on competition law rather than the rules on free movement of goods contained in Articles 34 and 36 of the TFEU. The relevant competition provisions of the TFEU are Articles 101 (1) and 102.

Article 101(1) of the TFEU provides that:

The following shall be prohibited as incompatible with the common market: all agreements between undertakings, decisions by associations of undertakings and concerted practices which may affect trade between Member States and which have as their object or effect the prevention, restriction or distortion of competition within the common market...

On its part, Article 102 of the TFEU stipulates that:

Any abuse by one or more undertakings of a dominant position within the common market or in a substantial part of it shall be prohibited as incompatible with the common market insofar as it may affect trade between Member States...

780 MANIATIS, S., “Trade Marks in Europe: A Practical Jurisprudence” (1st ed.) 454 (Sweet \& Maxwell, London 2006).

781 ECJ, Joined cases 56 and 58-64, Etablissements Consten S.a.R.L. and Grudig-VerkaufsGmbH v Commission of the European Community [1966] ECR 00299.

782 ECJ, Case 24/67 Parke, Davis and Co. v Probel, Reese, Beintema-Interpharm and Centrafarm [1968] ECR 00055, para. 2 of summary of the judgment.

783 ECJ, Case 40/70, Sirena S.r.l. v Eda S.r.l. and others [1971] ECR 00069, para. 1of summary of the judgment.

784 ECJ, Case 78/70, Deutsche Grammophon Gesellschaft mbHv Metro-SB-Großmärkte GmbH \& Co. KG. [1971] ECR 00487. 


\section{a) Grundig}

Grundig $^{785}$ is one of the early ECJ's cases which involved the exercise of intellectual property rights in a way that conflicts with the Community law. The material facts of the case present Grundig as a company registered in Bavaria, Germany. It owns, and affixes to all its goods, a trademark "GINT". Grundig entered into an exclusive distribution agreement with French Company Consten. The Grundig-Consten agreement manifests a win-win scenario: Consten is assured access to Grundig stocks on a condition that it must abstain from selling the stocks in EU countries other than France, whereas Grundig rewards Consten's forbearance by undertaking not to distribute similar products to Consten's business competitors in France. To ensure that no third party could export to France products bearing Grundig's GINT mark bought elsewhere, Consten registered the trade mark "GINT" as a French national mark. The registration was undertaken as a part of Grundig-Consten agreement. Analysing the circumstances surrounding the case, the ECJ concluded that the registration of GINT as a French national trade mark aimed at restricting parallel imports into France of Grundig products. Thus, the registration strengthened the contractual restrictions already agreed upon by the parties, with the consequences that no third party could import Grundig products from other Member States of the Community for resale in France "without running serious risks". 786

Having been convinced that the Grundig-Consten agreement aimed at "isolating the French market for Grundig Products and maintain artificially, for products of a very well-known brand, separate national markets within the Community", the ECJ held that the agreement distorted competition contrary to Article 101 of the TFEU. Drawing on the fact that the agreement prevented undertakings other than Consten from importing Grundig products into France, and at the same time restricted Consten from re-exporting those products to other countries of the common market, the ECJ held that the agreement affected trade between Member States contrary to the provisions of the TFEU. ${ }^{787}$

The ECJ hinted, indirectly, on the existence-exercise dichotomy by arguing that "the Community rules on competition do not allow the improper use of

785 ECJ, Joined cases 56 and 58-64, Etablissements Consten S.a.R.L. and Grudig-VerkaufsGmbH v Commission of the European Community [1966] ECR 00299.

$786 C f$. ECJ, Joined cases 56 and 58-64 Etablissements Consten S.a.R.L. and GrudigVerkaufs-GmbH v Commission of the European Community [1966] ECR 00299, para. 6 of summary of the judgment.

787 Cf. ECJ, Joined cases 56 and 58-64, Etablissements Consten S.a.R.L. and GrudigVerkaufs-GmbH v Commission of the European Community [1966] ECR 00299, para. 6 summary of the judgment. 
rights under national trade-mark law in order to frustrate the Community's law on cartels". ${ }^{788}$ With this conclusion, the ECJ intimated that the trade mark registration of the GINT mark made under the French law could not justify restriction on trade between Member States, since the registration in issue was secured in execution of a plan agreed upon by Grundig and Consten - a plan which contravenes the EU competition law.

\section{b) Parke}

Parke case ${ }^{789}$ depicts some weaknesses inherent in the Grundig-Consten judgment. The Grundig case basis solely on competition rules of the EC Treaty to prohibit proprietors of intellectual property right from relying on their rights to restrict trade between the EU Member States. In order for Article 101(1) of the TFEU to apply, it is necessary to prove the existence of an agreement..., or a decision... or concerted practice... which tends to restrict trade between Member States. ${ }^{790}$ This was not a case in Parke, which basically concerned reliance on a patent legally protected in the Netherlands. The patent covered medicinal products. The contentious issue was whether the proprietor of the patent in issue was justified to prohibit marketing, in the Netherlands, of similar medicinal products produced in another Member State where such medicinal products do not qualify for protection under patent law. The referring court had asked the ECJ to determine whether the action by the patentee was contrary to the provisions of Articles 101(1) and 102 of the TFEU. The ECJ affirmed that existence of a patent right protected in the Member State could not be affected by the prohibitions contained in the above provisions. Since there was no agreement, decision or concerted practice involved, the exercise of the said patent was not contrary to the provisions of Article 101(1) of the TFEU. In a case (such as Parke) in which the conditions required for Article 101(1) to apply are not fulfilled, the patentee can only be restrained from relying on his protected rights if he contravenes Article 102 of the TFEU. However, the exercise of patent right cannot be enjoined on the basis of Article 102 of the TFEU; unless it is proved that the right holder abused his dominant position.

788 Cf. ECJ, Joined cases 56 and 58-64, Etablissements Consten S.a.R.L. and GrudigVerkaufs-GmbH v Commission of the European Community [1966] ECR 00299, para. 10 of summary of the judgment.

789 Case 24/67 Parke, Davis and Co. v Probel, Reese, Beintema-Interpharm and Centrafarm [1968] ECR 00055.

790 ECJ, Case 24/67 Parke, Davis and Co. v Probel, Reese, Beintema-Interpharm and Centrafarm [1968] ECR 00055, para. 2 of summary of the judgment. 


\section{c) Sirena}

According to Sirena ${ }^{791}$ case, a contract for an assignment of a trade-mark will always be invalidated if it negatively affects trade between EU Member States. In the case at hand, an American company (henceforth the US company) owned a trade mark in connection with which it used to market cosmetics and medicinal cream worldwide. The US Company "sold, assigned and transferred all rights, titles and interests in the said trademark" to two European Companies, namely an Italian company (henceforth IT) and a German company (henceforth DE). ${ }^{792}$ Each company was required under the agreement to use the trade mark on its own territory. IT registered the trade mark in Italy in respect of cosmetic and medicinal products. DE sought to import in Italy cosmetic and medicinal products bearing a trade mark identical to that used by IT on identical goods. IT regarded such importation as an infringement of its trade mark registered in Italy and objected the importation. The following question was thus framed by the referring court (i.e. the Italian Court) soliciting the ECJ's response thereto: "assuming that the national law recognises the right of a trade-mark proprietor to impede imports from other Member States, does Community law affect the extent of this right?". ${ }^{793}$ As what might be seen as a response to this question, the ECJ conceded that:

A trade mark right, as a legal entity, does not in itself possess those elements of contract or concerted practice referred to in Article [101(1)]. Nevertheless, the exercise of that right might fall within the ambit of the prohibitions contained in the Treaty each time it manifests itself as the subject, the means or the result of a restrictive practice. When a trade mark right is exercised by virtue of assignments in one or more Member States, it is thus necessary to establish in each case whether such use leads to a situation falling under the prohibitions of Article [101]. ${ }^{794}$

While building on the principles established in Parke, ${ }^{795}$ the ECJ, in Sirena case, made some slight improvements on the former judgment. It clearly associated the rules in Articles 101(1) and 102 of the TFEU with the provisions of Article 36 of the TFEU which justifies, in certain instances, the exercise of intellectual property to prohibit free movement of goods. In this regard, a relevant paragraph of the judgment provides that:

791 ECJ, Case 40/70, Sirena S.r.l. v Eda S.r.l. and others [1971] ECR 00069.

792 ECJ, Case 40/70 Sirena S.r.l. v Eda S.r.l. and others [1971] ECR 00069, para. 2.

793 ECJ, Case 40/70, Sirena S.r.l. v Eda S.r.l. and others [1971] ECR 00069, para. 3.

794 ECJ, Case 40/70, Sirena S.r.l. v Eda S.r.l. and others [1971] ECR 00069, para. 9.

795 Cf. ECJ, Case 40/70, Sirena S.r.l. v Eda S.r.l. and others [1971] ECR 00069, para. 1 of summary of the judgment. 
... [Article 36], although it appears in the chapter of the Treaty dealing with quantitative restrictions on trade between Member States, is based on a principle equally applicable to the question of competition, in the sense that even if the rights recognised by the legislation of a Member State on the subject of industrial and commercial property are not affected, so far as the existence is concerned, by Articles [101 and 102 TFEU], their exercise may still fall under the prohibitions imposed by those provision. ${ }^{796}$

Thus, if the cumulative assignments to different users of a national trade mark protected in two or more Member States for the same product re-enacted "impenetrable frontiers between the Member States" a conclusion could be drawn that such practice affected as well trade between the Member States, and distorted competition in the common market ${ }^{797}$ - a fact that would lead sanctions against the said behaviour being proffered based on Articles 36 and 101(1) of the TFEU.

\section{d) Deutsche Grammophon}

In Deutsche Grammophon" 798 , the ECJ was asked to determine whether "the exclusive right of distributing the protected articles which is conferred by a national law on the manufacturer of sound recordings may, without infringing Community provisions, prevent the marketing on national territory of products lawfully distributed by such manufacturer or with his consent on the territory of another Member State". The court was urged to respond to this question in the light of the provisions of Article 101(1) of the TFEU. ${ }^{799}$ However, the ECJ "widened the scope of the question, linked competition with free movement, and exported the distinction between existence and exercise of a right from the field of competition to that of free movement of goods" ${ }^{800}$ This new approach acknowledges the fact that the exercise of intellectual property rights which does not result from an agreement between the parties cannot be enjoined under Article 101(1) TFEU even where such exercise produces some shrewd effects on the common market. However, under the circumstances as the foregoing, it is necessary for the court to consider whether such use is in consonance with other provisions of TFEU especially those concerning free movement of goods. ${ }^{801}$

796 ECJ, Case 40/70, Sirena S.r.l. v Eda S.r.l. and others [1971] ECR 00069, para. 5.

797 ECJ, Case 40/70, Sirena S.r.l. v Eda S.r.l. and others [1971] ECR 00069, para. 10.

798 ECJ, Case 78/70, Deutsche Grammophon Gesellschaft mbH v Metro-SB-Großmärkte GmbH \& Co. KG. [1971] ECR 00487.

799 Cf. Case 78/70 Deutsche Grammophon [1971] ECR 00487, para. 4.

800 Cf. MANIATIS, S., "Trade Marks in Europe: A Practical Jurisprudence" (1st ed.) 455 (Sweet \& Maxwell, London 2006).

$801 C f$. ECJ, Case 78/70, Deutsche Grammophon [1971] ECR 00487, para. 7. 
The aim of attaining a single market in the European Community provided an impulse for the ECJ to link competition rules and the principles of free movement of goods contained in Article 36 of the TFEU. ${ }^{802}$

Returning to the provisions of Article 36 of the TFEU, the court, justifiably, made a distinction between existence and exercise of industrial property rights as follows:

Amongst the prohibitions or restrictions on the free movement of goods which it concedes Article [36] refers to industrial and commercial property. On the assumption that those provisions may be relevant to a right related to a copyright, it is nevertheless clear from that Article [36] that, although the Treaty does not affect the existence of rights recognised by the legislation of a Member State with regard to industrial and commercial property, the exercise of such rights may nevertheless fall within the prohibitions laid down in the Treaty. ${ }^{803}$

Adding to the foregoing, the ECJ made an important step for the protection of the European internal market by providing a predictable demarcation of the extent to which intellectual property rights may be based upon to abrogate the freedom of movement of goods:

Although it permits prohibitions or restrictions on the free movement of products, which are justified for the purpose of protecting industrial and commercial property, Article [36] only admits derogations from that freedom to the extent to which they are justified for the purpose of safeguarding rights which constitute the specific-subject matter of such property. ${ }^{804}$

The court did not, however, provide a firm interpretation of what constituted "specific subject-matter" of intellectual property.

\section{Specific subject-matter of intellectual property}

The principle of specific subject matter of intellectual property right essentially means that when a trade between Member States may be affected by a proprietor who relies on his right, such reliance must be justified on the grounds of protecting the specific subject-matter of the right concerned. The principle, therefore, aims to prevent trade mark rights to be used to "partition off national markets" and thereby restrict trade between the Member States, in a situation where no such restriction was necessary to guarantee the essence of the exclusive right flowing from the trade mark. ${ }^{805}$ Where the reason is to protect a specific

802 Cf. ECJ, Case 78/70, Deutsche Grammophon [1971] ECR 00487, para. 8.

803 Cf. ECJ, Case 78/70, Deutsche Grammophon [1971] ECR 00487, para. 11.

$804 C f$. ECJ, Case 78/70, Deutsche Grammophon [1971] ECR 00487, para. 11.

805 ECJ, Case C-16/74, Centrafarm BV et Adriaan de Peijper v Winthrop BV [1974] ECR 
subject-matter of an intellectual property right, derogation from the Community law requiring unhampered free movement of goods will be justified. ${ }^{806}$

Each type of intellectual property has a specific subject-matter which it protects:

In relation to trade marks, the specific subject-matter ... is the guarantee that the owner of the trade mark has the exclusive right to use that trade mark, for the purpose of putting products protected by the trade mark into circulation for the first time, and is therefore intended to protect him against competitors wishing to take advantage of the status and reputation of the trade mark by selling products illegally bearing that trade mark. ${ }^{807}$

It is apparent that a trade mark proprietor may not prohibit marketing in his national territory of a product put on the market of another Member State by himself or with his consent, since under this scenario, the proprietor will be presumed to have profited from the specific subject-matter of the protection extended to his trade mark.

The ECJ has however held that the scope of the right to enjoy a specific subject-matter of a trade mark can be determined by making a reference to essential function of a trade mark. ${ }^{808}$

\section{Essential function of a trade mark}

The ECJ made it clear in Hoffmann-La Roche ${ }^{809}$ that the essential function of a trade mark was to guarantee "the identity of the origin of the trade-marked product to the consumer or ultimate user, by enabling him without any possibility of confusion to distinguish that product from products which have another origin". The essential function of trade marks is therefore to provide an assurance to the ultimate consumer that a branded good which is being marketed to him comes directly from the proprietor of a trade mark or from a person authorised to use a mark by the proprietor so that the consumer is certain of quality of the products usually bearing the proprietor's mark. ${ }^{810}$ In the event third

01183, para. 11.

806 ECJ, Case C-16/74, Centrafarm BV et Adriaan de Peijper v Winthrop BV [1974] ECR 01183 , para. 8.

807 ECJ, Case C-23/78, Hoffmann-La Roche \& Co. AG v Centrafarm [1978] ECR 01139, para. 7.

808 ECJ, Case C-10/89, SA CNL-Sucal NV v HAG G AG [1990] ECR I-03711, para. 14.

809 ECJ, Case C-102/77, Hoffmann-La Roche \& Co. AG v Centrafarm [1978] ECR 01139, para. 7.

810 ECJ, Case C-102/77, Hoffmann-La Roche \& Co. AG v Centrafarm [1978] ECR 01139, para. 7. 
parties interfere with the essential function of a trade mark, the proprietor will not be able to enjoy the specific subject-matter of his trade mark.

It follows naturally that the proprietor can enforce his specific subject matter of a CTM based on the essential function of a trade mark as well. This could happen if a third party, who has no authorisation to a use a mark, markets the goods bearing the mark in such a way as to impair the "guarantee of origin". ${ }^{811}$

It is important to note that the principles of specific subject matter and the essential function of trade mark right are relied upon by the ECJ to define the extent to which manufacturers and/or trade mark proprietors may rely on the principle of trade mark exhaustion stipulated in Articles 7 and 13 of the TD and the CTMR respectively, to prohibit free movement of goods. As is shown in section $\mathrm{C}$ below, the principle of exhaustion is the ECJ's approach to the balancing of two opposing interests, namely, the fundamental tenet of free movement of goods assured by Article 34 of the TFEU and the legitimate interests, which trade mark proprietors can enforce based on Articles 345 and 36 of the TFEU. ${ }^{812}$

\section{Exhaustion of trade mark rights}

\section{Delineation and forms of trade mark exhaustion}

Section C (I) (2) (a) of chapter 3 hints to the fact that a regime for trade mark exhaustion is usually delimited to a specific geographical area ${ }^{813}$ The doctrine of trade mark exhaustion in the EU "relates to the territory of the Member States". The European Union applies to the Community trade mark regime the principle of regional exhaustion based on Article 13(1) of the CTMR. Similarly, Member States are required under Article 7(1) of the TD to apply the principle of regional exhaustion to trade mark rights protected under the national law. Pursuant to the principle of regional exhaustion, "trade mark rights cannot be invoked to restrain the free movement of goods within the EU, but they can be used to restrain the entry of such goods into the EU". ${ }^{814}$ Thus, regional exhaustion of CTM rights is

811 ECJ, Case C-102/77, Hoffmann-La Roche \& Co. AG v Centrafarm [1978] ECR 01139, para. 7.

812 ENCHELMAIER, S., "the inexhaustible question - free movement of goods and intellectual property in the European Court of Justice's Case Law, 2002-2006", 38(4) IIC 453 (2007).

813 Cf. STUCKI, M., "Trademarks and Free Trade" 26 (Staempfli Verlag AG, Bern 1997).

$814 C f$. Commission of the European Communities, "possible abuses of trade mark rights within the EU in the context of Community exhaustion", Commission Staff Working 
a "necessary tool to safeguard the objective of the establishment of a single market. Any other solution would inevitably lead to the fragmentation and partitioning of the market". ${ }^{815}$

Regional exhaustion of CTM rights can be differentiated in a number of ways from national and international exhaustion. ${ }^{816}$ In the context of national exhaustion, the trademark proprietor waives his rights in relation to goods he puts on the national market. This leaves him with the freedom to prevent importation of the goods in his own territory, where the said goods have not been marketed in the national market by the proprietor or any other person with the trade-mark owner's approval. With regard to international exhaustion, the trade mark proprietor cannot control subsequent marketing of his products which he has sold in a particular country. It does not make any difference if he markets the goods in the country where the trade mark is registered or in a third country where the trade mark does not enjoy any protection. The decisive factor is the first marketing of the product in any part of the world, after which event trade mark rights exhaust globally. ${ }^{817}$

\section{Rationale of Community trade mark exhaustion}

One reckons with the fact that while the principles underlying Community trade mark exhaustion were developed to meet the desire of having an undivided market in Europe,${ }^{818}$ adaption of regional trade mark exhaustion to CTM went beyond the initial motives. If the aim were just to ensure that goods circulated freely after the first sale, the doctrine of international trade mark exhaustion would as well have achieved the same end. It would therefore seem that besides the urge to meet the demand of undivided EU's internal market, the legislature had also to take account of the interests of the EU's business community. This can be viewed in light of the features characterising the principle of regional exhaustion. The principle enables CTM proprietors to market their branded

Paper No. SEC (2003) 575.

815 STAMATOUDI, I. A. \& TORREMANS, P.L.C., "International exhaustion in the European Union in the Light of "Zino Davidoff": Contract Versus Trade Mark Law", 31(2) IIC 123, 125 (2000).

816 National and international exhaustion principles are discussed in section C (I) (2) of chapter 3 supra.

817 Cf. TORREMANS, P., "Holyoak and Torremans Intellectual Property Law" 448 Oxford University Press, Oxford 2008).

818 Cf. FRANZOSI, M., "Grey Market - Parallel Importation as a Trademark violation or an Act of Unfair Competition”, 21(2) IIC 194, 203 (1990). 
goods outside the EU Common Market without exhausting the rights within it. ${ }^{819}$ Thus, the Community-wide trade mark exhaustion is inclined to protect the competitiveness of the EU industry since, by giving power to the EU companies to decide where the initial marketing of their products takes place; EU companies are given an incentive to invest in new brands with high quality of goods and services. ${ }^{820}$ If adapted, international exhaustion would defeat this noble objective, since the EU Common Market could no longer be reserved for EU undertakings or establishments alone. Goods placed in the market outside the EU would easily find their way back to the EU market. To put it simply, the "flow of goods into the EU could not be restrained" on the basis of CTM rights. $^{821}$

The ECJ, in Silhouette case, ${ }^{822}$ made it clear that Member States were not allowed to introduce the principle of international exhaustion of trademark rights in their domestic laws. The case concerned re-importation, into Austria, of goods originally produced by the proprietor of a trade mark registered in Austria. The proprietor, who opposed such re-importation, had marketed the goods in Bulgaria. ${ }^{823}$ Although Austria had already implemented Article 7 of the Community trade mark directive, authorities in this country were unsure whether the principle of regional exhaustion contained in the Directive rendered inapplicable the principle of international exhaustion, which originally contained in the Austrian trade mark law. ${ }^{824}$ The ECJ ruled out the principle of international exhaustion of trade mark rights protected in the EU Member States by providing that "... national rules providing for exhaustion of trade-mark rights in respect of products put on the market outside the EEA under that mark by the proprietor or with his consent are contrary to Article 7(1) of the Directive". ${ }^{825}$

To the extent that they do not support the principle of international exhaustion of trade mark rights, the Community trade mark directive, the CTMR and the Silhouette decision may be criticised. Proponents of international exhaustion

819 ECJ, joined cases C-414/99 to C-416/99 ZinoDavidoff SA [2001] ECR I-08691, para. 33.

$820 C f$. ZARPELLON, S., "The scope of the exhaustion regime for trade marks rights", 22(9) E.C.L.R. 382, 386 \& 386 (2001).

$821 C f$. Commission of the European Communities, "possible abuses of trade mark rights within the EU in the context of Community exhaustion", Commission Staff Working Paper No. SEC (2003) 575, at section 2.

$822 C f$. ECJ, Case C-355/96, Silhouette International Schmied GmbH \& Co. KG v Hartlauer Handelsgesellschaft mbH [1998] ECR I-04799, para. 39.

823 Note that, when the Silhouette judgment was rendered in 1998, Bulgaria had not yet secured the EU membership.

824 As per explanatory memorandum to the Austrian law implementing Article 7 of the Directive ( $c f$. ECJ, Case C-355/96, Silhouette[1998] ECR I-04799, para. 12). 
argue that the principle of regional trade mark exhaustion discourages parallel importation notwithstanding some justifiable policy grounds. ${ }^{826}$ Parallel importation is a tool that limits the ability of trade mark owners to dissect the global markets into pieces of national or regional markets. As a tangible benefit of this tool, intra-brand competition is enhanced with the results that the prices of branded goods are reduced. Moreover, essential function of trade mark supports the practice of parallel trade, for the essence of trade mark regime is to guarantee the origin of trade-marked goods and hence their quality. ${ }^{827}$ This guarantee remains unaffected by a normal practice of parallel importation except in some isolated scenarios, discussed in section C (III) below in this chapter, in which the practice of parallel importation is likely to contravene some legitimate interests of trade mark proprietors especially where the condition of goods is impaired or the packaging is changed.

\section{Conditions for Community trade mark exhaustion}

Pursuant to the provisions of Articles 7(1) and 13(1) of the TD and the CTMR respectively, a "trade mark owner's rights are exhausted in respect of specific goods once he puts those goods on the market in the EEA himself or if he has either expressly or impliedly consented to those goods being marketed there". ${ }^{828}$ The purpose of Articles 7(1) and 13(1) of the TD and the CTMR is "to make possible the further marketing of an individual item of a product bearing a trade mark that has been put on the market with the consent of the trade-mark proprietor and to prevent him from opposing such marketing". 829

To the extent the trade mark proprietor is able to adduce some legitimate reasons justifying his action of opposing further commercialisation of the goods to whose sale he has already consented, the doctrine of exhaustion will not apply in respect of those goods. This could particularly be the case, if the "the condition of the goods has been changed or impaired after they have been put on the market". ${ }^{830}$

826 Cf. N. GROSS, "Trade mark exhaustion: The U.K. perspective”, 23(5) E.I.P.R. 224, 228 (2001).

827 Cf. ECJ, Case C-173/98, Sebago Inc. SA v G-B Unic SA [1999] ECR I-04103, para. 16.

828 PHILIPS, J., "Trade Mark Law: A Practical Anatomy” 285 (Oxford University Press, Oxford 2003).

829 ECJ, Case C-173/98, Sebago Inc. and Ancianne Maison Dubois \& Fils SA v G-B Unic SA [1999] ECR I-04103, para. 20.

$830 C f$. Articles 7(2) and 13(2) of TD and CTMR respectively. 
Trade mark rights protected in Europe cannot be regarded as exhausted, unless it is proved that not only the goods have been put on the market but also that the putting of goods on the market was accompanied by a clear consent on the part of the trade mark proprietor.

\section{Putting goods on the market}

The central question in this section is whether the mere putting of trade-marked goods on the market exhausts the trade mark proprietor's exclusive rights. The term "putting goods on the market" simply means an act of marketing the goods in the Community. The term can be clearly and precisely explained in light of the Peak Holding case. ${ }^{831}$ The dispute in this case concerned the use of Peak Performance trade mark owned by Peak Holding - a group of companies. Peak Performance Production AB (henceforth the claimant), being a member of that group, was able to secure some rights to use the trade mark in relation to clothing and accessories, that it produced and marketed in Sweden and in other countries. Factory Outlet (henceforth the defendant) carried out parallel imports of goods bearing claimant's trade mark in Sweden. It transpired that the goods in issue were manufactured outside the EU and imported into the EU by the claimant, who put the products in production shops and in base camp stores for purpose of selling them to final consumers. The defendant received the claimant's products from another dealer (independent of the claimant) before those goods were actually sold in the EU by the claimant. The defendant maintained that the goods had been put on the market by virtue: (i) of their import into the internal market by the claimant with the intention of selling the goods in the Community, and (ii) of having been marketed by the claimant in its own shops and the Base Camp Store. The defendant reiterated that, in the foregoing circumstances, the goods had been offered to consumers. ${ }^{832}$

As the defendant's submissions necessitated a legal interpretation of the term "putting goods on the market", the ECJ responded that:

... goods bearing a trade mark cannot be regarded as having been put on the market in the EEA where the proprietor of the trade mark has imported them into the EEA with a view to selling them there or where he has offered them for sell to consumers in the EEA, in his own shops or those of an associated company, without actually selling them. ${ }^{833}$

831 ECJ, Case C-16/03, Peak Holding AB v Axolin-Elinor AB [2004] ECR I-11313.

$832 C f$. Case C-16/03, Peak Holding AB v Axolin-Elinor AB [2004] ECR I-11313, paras. 6 to 18.

833 ECJ, Case C-16/03, Peak Holding AB v Axolin-Elinor AB [2004] ECR I-11313, para. 44. 
The argument in the above quotation is based on the legal position which regards an act of placing the goods on the market outside the EEA as incapable of exhausting the trade mark owner's right to prohibit the importation of those goods. ${ }^{834}$ This legal position reflects the mind of the EU legislature expressed in Articles 9 and 13 of the CTMR. It must be recalled that Article 9 grants a CTM proprietor some exclusive rights, whereas Article 13 tactically limits those rights in a way that does not affect the right of a trade mark proprietor to control the initial marketing of the goods in the EEA of goods bearing the mark. ${ }^{835}$ Both Articles 9 and 13 of the CTMR incorporate the term "putting the goods on the market", albeit in different connotations.

It is noteworthy that Article 9(2) of the CTMR stipulates some specific acts in relation to a trade mark, which can only be perpetuated by a trade mark proprietor or another person authorised by him. Some of these acts include: (a) affixing the signs to goods or to the packaging thereof; (b) offering the goods, putting them on the market or stocking them for these purposes under that sign, or offering or supplying services thereunder; (c) importing or exporting the goods under that sign. The term "putting them on the market" appearing in Article 9(2) (b) has been interpreted differently from a semantically similar term found in Article 13(1). The term "putting on the market" as a sword which the CTM proprietor may apply against third parties pursuant to Article 9(2) (b) is not necessarily confined to actual selling of the branded products but encompasses as well an act of putting the goods in the shop for the purposes of selling them or any act of putting the goods in the state which would constitute an act of selling. ${ }^{836}$ However, the term as applied in the context of Article 13(1) to restrict the proprietor from controlling the after-market goods, refers to an actual sale of the product concerned. ${ }^{837}$ This is opposed to merely stocking the goods in a shop waiting for customers to buy the goods. Thus, goods offered in a shop have been put on the market for the purpose of Article 9(2) of CTMR but not for the purpose of Article 13(1) of the CTMR. ${ }^{838}$

It cannot be presumed that where a trade mark proprietor imports his goods with a view to selling them in the EEA or offers them for sale in the EEA, has

834 ECJ, Case C-16/03 Peak Holding AB v Axolin-Elinor AB [2004] ECR I-11313, para. 36.

835 Opinion of Advocate General Stix-Hackl, in: ECJ, Case C-16/03, Peak Holding [2004]

ECR I-11313, para. 20.

836 Opinion of Advocate General Stix-Hackl, in: C-16/03, Peak Holding [2004] ECR I11313 , paras. $28 \& 29$.

837 Opinion of Advocate General Stix-Hackl, in: C-16/03, Peak Holding [2004] ECR I11313, para. 40.

838 Opinion of Advocate General Stix-Hackl, in: C-16/03, Peak Holding [2004] ECR I11313 , paras. $36 \& 37$. 
put the goods on the market within the meaning of Article 13(1) of CTMR. ${ }^{839}$ Through these acts, the CTM owner does not dispose of the goods nor does he "realise the economic value of his trade mark" ${ }^{840}$ Thus, putting the goods on the market within the meaning of Article 13(1) signifies an act of actual sale of a branded good for the first time. Thereafter, any third parties are free to put the same good on the market for the subsequent times without infringing exclusive trade mark rights enjoyed by the proprietor under Article 9 of CTMR.

\section{Consent}

The term "consent" as stipulated in Article 13 of CTMR refers to an act of putting the goods on a market in the EEA. The purpose of requiring the proprietor's consent as a condition for trade mark rights to be exhausted is to allow the CTM owner to control where and when initial marketing of his branded product(s) should take place. Thus, consent is a legal proof of the fact that the proprietor has renounced his exclusive CTM rights. ${ }^{841}$ Evidence of such renunciation is governed by the rule that (i) consent is required for each specific batch of goods sold, (ii) implied consent can only be inferred from unequivocal facts, and (iii) contractual restrictions between the parties do not extend to the principle of trade mark exhaustion.

\section{a) Consent is given for specific goods}

Consent, for purpose of CTM exhaustion, relates only to specific goods whose initial marketing was done by the proprietor himself or any other person with the proprietor's approval. The trade mark owner's consent in relation to a single batch of goods "does not exhaust the rights conferred by the trade mark as regards the marketing of other batches of his goods even if they are identical". ${ }^{842}$ This position is confirmed in Article 13(2) of CTMR. By employing the phrase "further commercialisation of goods", Article 13(2) limits the principle of

839 Indeed, if a mere importation customs clearance of branded goods could be considered as exhausting trade mark rights, the "proprietor would, in the final analysis, have no control over the first sale of the goods in the EEA" ( $c f$. opinion of Advocate General Stix-Hackl, in Case C-16/03, Peak Holding [2004] ECR I-11313, para. 25).

840 ECJ, Case C-16/03, Peak Holding AB v Axolin-Elinor AB [2004] ECR I-11313, para. 42.

841 ECJ, Case C-244/00 Van Doren $+Q$. GmbH v Lifestyle sports + sportswear Handelsgesellschaft mbH and Michael Orth [2003] ECR I-03051, para. 34.

842 ECJ, Case C-173/98, Sebago Inc SA v G-B Unic SA [1999] ECR I-04103, para. 15. 
exhaustion to "only specific goods which have first been put on the market with the consent of the trade-mark proprietor". 843

\section{b) Express and implied consent}

Consent for the sale of specific batch of goods must be expressed positively. The case law provides an appropriate response to the question whether a trade-mark proprietor's consent must be express, or whether it may also be implied. In Zino Davidoff, ${ }^{844}$ the ECJ was called upon to clarify the circumstances under which a trade mark owner may be presumed "as having consented, directly or indirectly, to the importation and marketing in the EEA by third parties who currently own them, of products bearing that trade mark, which have been placed on the market outside the EEA by the proprietor of the mark or with his consent". The court's findings attached great weight to the fact that the proprietor's consent extinguishes the trade mark owner's exclusive rights that enable him to control the initial marketing in the EEA. In view of this serious effect, the court held that "consent must be so expressed that an intention to renounce those rights is unequivocally demonstrated". ${ }^{845}$ While the proprietor's intention to renounce his exclusive rights is derived from an express statement of consent, in some cases, such intention may also be discerned from "facts and circumstances prior to, simultaneous with or subsequent to the placing of the goods on the market outside the EEA". ${ }^{846}$ These facts and circumstances must, nonetheless, demonstrate unambiguously that the proprietor signified his intention to renounce his rights. It follows that where consent is not expressly given, an implied consent can be endorsed by the court only if the facts of the case demonstrate, unequivocally, that "the trade mark proprietor has renounced any intention to enforce his exclusive rights". ${ }^{847}$ However, implied consent, for the marketing of the goods in the EU of the goods initially marketed outside the EU market, cannot be discerned from the fact that the trade mark proprietor was silent and/or did not oppose the subsequent marketing of the goods in the EU or the goods did not carry with them the proprietor's notice to such opposition. ${ }^{848}$

843 ECJ, Case C-173/98, Sebago Inc. SA v G-B Unic SA [1999] ECR I-04103, para. 20.

844 ECJ, joined cases C-414/99 to 416/99, Zino Davidoff [2001] ECR I-0869, para. 34.

845 ECJ, joined cases C-414/99 to 416/99, Zino Davidoff [2001] ECR I-0869, para. 45.

846 ECJ, joined cases C-414/99 to 416/99, Zino Davidoff [2001] ECR I-0869, para. 46.

847 ECJ, joined cases C-414/99 to 416/99, Zino Davidoff [2001] ECR I-0869, para. 53.

848 ECJ, joined cases C-414/99 to 416/99, Zino Davidoff [2001] ECR I-0869, paras. 55 - 58. 
c) Contractual restrictions do not vitiate consent

It is of particular interests to enquire whether, a third party, who buys some branded products, can be prohibited, by a contract between him and the trade mark proprietor, to resale those goods in the EEA.

Contractual restrictions on resale may be elaborated under two instances. The first instance relates to a scenario in which a trade mark proprietor sells the branded product in the market outside the EEA with an express prohibition from reselling the product in the EEA. This scenario reflects the facts of Zino Davidoff $^{849}$ which reveal that the company Zino Davidoff $S A$ (henceforth the claimant) owns cool water and Davidoff Cool Water trade marks registered in the United Kingdom. The claimant uses the two trade marks to market, within and outside the EU, a wide range of toiletries and cosmetics. ${ }^{850}$ The claimant sold the products to a trader (henceforth the distributor) in Singapore pursuant to an exclusive distribution agreement which required the distributor not to resell the products into the EU. The distributor undertook as well to impose the same restrictions on traders to whom the goods were subsequently distributed by the distributor. It transpired that A \& G Imports Ltd (henceforth the defendant) acquired the claimant's products produced in the EU but which had been sold, legally, in Singapore. The defendant re-imported the products into the United Kingdom. The claimant alleged that by importing and selling the goods in the United Kingdom, the defendant infringed the claimant's rights, and thus bringing the question of consent required under Article 13(1) of CTMR in issue, since the claimant submitted that it had not consented to the marketing of the goods in the EU. In view of these facts, contractual prohibition would seem unnecessary for the trade mark proprietor to achieve his aim of keeping the goods out of the EEA market, since the doctrine of Community-wide exhaustion allows a trade mark owner to market goods outside the EU common market without exhausting the rights within the EU market. ${ }^{851}$

The second instance may be exemplified by a scenario in which a trade mark owner sells the product to a purchaser in the EEA with a restriction on resale of the purchased product in the EEA. This is a typical situation reflected in Peak Holding case, ${ }^{852}$ in which the claimant sold the goods to the defendant

849 ECJ, joined cases C-414/99 to 416/99, Zino Davidoff [2001] ECR I-0869, para. 34.

$850 C f$. Council Directive 76/768/EEC of 27 July 1976 on the approximation of the laws of the Member States relating to Cosmetic products (OJ 1976 L 262, p. 169), which was implemented in the United Kingdom by the Cosmetic Products (Safety) Regulations 1996 (SI 2925/1996).

$851 C f$. ECJ, joined cases C-414/99 to 416/99, Zino Davidoff [2001] ECR I-0869, para. 33.

852 ECJ, Case C-16/03, Peak Holding AB v Axolin-Elinor AB [2004] ECR I-11313. 
established in France. The defendant signed an undertaking stipulating that it (the defendant) was not allowed to resell the products in European countries other than Russia and Slovenia. ${ }^{853}$ The court held that:

...the stipulation, in a contract of sale concluded between the proprietor of the trade mark and an operator established in the EEA, of a prohibition on reselling in the EEA does not mean that there is no putting on the market in the EEA within the meaning of Article 7(1) of the Directive and thus does not preclude the exhaustion of the proprietor's exclusive rights in the event of resale in the EEA in breach of the prohibition. ${ }^{854}$

The court clarified further that any territorial restrictions on the right to resell the goods imposed on a purchaser by a contract concerns only the relations between the parties to the contract. ${ }^{855}$ This confirms the elaborative opinion, of AdvocateGeneral Stix-Hackl, which holds that:

...exhaustion of rights arises by operation of law, irrespective of the contract between the proprietor and purchaser. Breach of any territorial restrictions on sale which the proprietor may have imposed on a purchaser of the goods in relation to their sale in the EEA may give rise to claims under the contract, but is not relevant in principle under trade mark law. ${ }^{856}$

In the light of the holding in the above cases, it is appropriate to conclude that the rights of the trade mark proprietor within the Member States of the Community are determined by the Community legislature. It is therefore, unacceptable to apply the national law of contract to limit the rights of the trade mark proprietor (such as where goods, which were marketed outside the EEA, are considered exhausted), or to extend those rights beyond the parameters set out in Article 13(1) of CTMR (i.e. where the contract allows the proprietor to retain control over the after-market goods).

\section{Burden of proof in relation to exhaustion}

The general rule of evidence places a burden on whoever alleges existence of certain facts to prove those facts. In light of this rule, it would seem that a defendant who pleads exhaustion as a defence against trade mark infringement has to prove that the proprietor's rights in branded-goods are exhausted. ${ }^{857}$ Under

853 ECJ, Case C-16/03, Peak Holding AB v Axolin-Elinor AB [2004] ECR I-11313, para. 12.

854 ECJ, Case C-16/03, Peak Holding $A B v$ Axolin-Elinor $A B$ [2004] ECR I-11313, para. 56.

855 ECJ, Case C-16/03, Peak Holding $A B v$ Axolin-Elinor $A B$ [2004] ECR I-11313, para. 54.

856 Cf. opinion of Advocate-General, in: Case C-16/03, Peak Holding [2004] ECR I-11313, para. 49.

857 ECJ, Case C-244/00 Van Doren + Q. GmbH v Lifestyle sports + sportswear Handelsgesellschaft mbH and Michael Orth [2003] ECR I-03051, para. 35. 
certain circumstances, the court may depart from the general rule of evidence especially if placing a burden of proof on the defendant may lead to the partitioning of the internal market contrary to the provisions of Articles 34 and 36 of TFEU. In the Van Doren case ${ }^{858}$ the ECJ appreciated the need to qualify the above general rule of evidence in order to avoid a conflict with the principle of free movement of goods.

One would wonder as under which circumstances could a rule requiring a defendant to prove that the trade mark proprietor's rights are exhausted interfere with the free movement of goods. Manufacturers have unhampered powers to establish own exclusive marketing or distribution systems. Under most exclusive distribution systems, manufacturers supply their products only to distributors who are faithful to the distribution scheme. The manufacturers ensure that only members of the exclusive distribution systems get the supplies. In so doing, the manufacturer is able to partition the internal market. A third party's commercial interests in maintaining future supplies require him not to disclose a distributor (belonging to the exclusive distribution system) who sells the goods to him, since if disclosed, the manufacturer would stop supplying his products to this unfaithful distributor.

A defendant who raises a reasonable doubt that "there is a real risk of partitioning of national markets if he himself bears the burden of proving that the goods were placed on the market in the EEA by the proprietor of the trade mark or with his consent", ${ }^{859}$ is discharged from that burden. Instead, the burden shifts to the trade mark proprietor by being required to adduce evidence showing that he had never sold the goods in the EU, and the goods in respect of which a third party claims exhaustion were marketed by the proprietor of the trade mark outside the EEA. The burden shifts again to the defendant to prove that even if the goods were marketed outside the EEA, they were thereafter marketed in the EEA with the consent of the trade mark proprietor. ${ }^{860}$

\section{Factors vitiating exhaustion}

The principle of exhaustion provided in 13(1) above can be derogated from on the basis of Article 13(2) of CTMR. ${ }^{861}$ According to the Article, CTM rights are

858 ECJ, Case C-244/00, Van Doren + Q. GmbH, ibid., para. 37.

859 ECJ, Case C-244/00, Van Doren + Q. GmbH, ibid., para. 41.

860 ECJ, Case C-244/00, Van Doren + Q. GmbH, ibid., para. 41.

861 Cf. BAINBRIDGE, D. I., "Intellectual Property" (6th ed.) 782 (Longman, London 2007). 
not exhausted "where there exist legitimate reasons for the proprietor to oppose further commercialisation of the goods, especially where the condition of the goods is changed or impaired after they have been put on the market". A central question in relation to Article 13(2) of CTMR hinges on the interpretation of the term "legitimate reasons" and "change or impairment of the condition of the goods".

The term "legitimate reason" is too general to be ascribed to a single notion. The term is capable of encompassing several scenarios in which a trade mark proprietor may prohibit further commercialisation of his branded products notwithstanding his consent to the first sale of the products in issue. Reasons can always be considered legitimate if they are supported by the law. In the context of trade mark rights, legitimate reasons entitle the CTM proprietor to enforce against third parties his legitimate expectations in relation to his trade mark. The trade mark proprietor has a legitimate expectation to maintain goodwill of his CTM by marketing quality goods. This constitutes a legitimate reason for him to prohibit further marketing of products, by recalling them, if it appears that the products under his CTM have contaminated some obnoxious elements and their continued sale would negatively impact on his legitimate expectations of maintaining a high-quality brand.

Legitimate reasons exist as well if for whatever reasons imported products "contravened local ingredient-labelling regulations or their packaging infringed intellectual property rights which were owned locally by third parties". ${ }^{862}$ Under these circumstances, the trade mark proprietor will have legitimate reasons to prohibit resale of those products, as he will be supported by the law.

Article 13(2) hints as to what might inclusively constitute legitimate reason on which the trade mark proprietor may base to prohibit resale of the products. The Article specifies, without giving tangible examples that the defendant's act of changing or impairing the original condition of the goods is against the trade mark proprietor's legitimate interests. It follows that the proprietor will have a justified cause to control the after-market goods by opposing resale of his products, which had been stored inappropriately, especially if the quality of these goods has been affected to an appreciable degree.

The subject under Article 13(2) may better be explored based on repackaging cases.

862 PHILIPS, J., “Trade Mark Law: A Practical Anatomy” 291 (Oxford University Press, Oxford 2003). 


\section{Repackaging and re-affixing of a trade mark}

Parallel importers have a tendency of buying the branded goods in their original forms and modify their packaging in a way that would enable them market the repackaged goods parallel to the original goods being sold by the trade mark proprietor. As long as the repackaging and/or re-affixing of the trade mark does not contravene the trade mark's essential function and specific subject-matter, a third party cannot be enjoined from competing with the trade mark proprietor. It has to be recalled that the concept "essential function" in relation to trade mark, is associated with the trade mark's perceived ability to guarantee the origins and quality of the goods. In view of this principle, the repackaged goods still originate from the trade mark owner; hence, the proprietor's mark re-affixed on the packaging of the repackaged goods fulfils faithfully the essential function of guaranteeing the origin of the goods. What is questionable, however, is whether the re-affixed trade mark can still faithfully guarantee that the quality of the repackaged goods is the same as that of the original goods. Generally speaking, "so long as the third party has made only objectively necessary modifications to the packaging of the goods, the trade mark proprietor cannot complain, and so such modifications are deemed permissible". ${ }^{863}$

The ECJ has, in a number of cases, ${ }^{864}$ clarified some factors that can be relied upon to allow a third party to resale the repackaged goods notwithstanding the trade-mark proprietor's objections. Consequently, the trade-mark proprietor cannot oppose marketing of repackaged products if the third party is able to adduce evidence showing that (1) there is a danger of partitioning the internal market; (2) the repackaging does not affect the condition of the product; (3) a notice to the trade mark proprietor has been given; (4) identity of the person who repackaged the goods is legibly indicated on the packaging; and (5) repackaging does not damage the reputation of a the trade mark concerned. These factors are considered below.

863 EDENBOROUGH, M., "The Free Movement of Trade Marked Goods in the European Community", in: POULTER, A., BROWNLOW, P. \& GYNGELL, J. (eds.), "The Community Trade Mark: Regulations, Practice and Procedures" (2nd ed., Release \#4) XII.16 (INTA, New York 2005).

864 The first case to deal with repackaging of branded products was ECJ, Case 102/77, Hoffmann-La Roche \& Co. AG v Vertriebsgesellschaft Pharmazeutischer Erzeugnisse $m b H$ [1978] ECR 01139. The principles set out in this case have been relied upon in various subsequent ECJ's decisions such as the joined cases C-427/93, C-429/93 and 436/93 Bristol-Myers Squibb v Panarova [1996] ECR I-3457 (which has become a leading decision on issues regarding repackaging of pharmaceutical products), Case C276/05 The Wellcome Foundation Ltd v Paranova Pharmarzeutika Handels GmbH [2008] ECR I-10479; (also reported in 40(7) IIC 874 et seq. (2009). 
a) Artificial partitioning of the common market

Member States have different requirements and practices relating to the size of the packets of branded products, pharmaceutical products in particular. In certain instances health insurance companies make reimbursement of medical expenses subject to the "size of the packaging, or a well-established medical prescription practices based, inter alia, on standard sizes recommended by professional groups and sickness insurance institutions". ${ }^{865}$ Usually the package of the product bears some description of the product concerned. The description language may differ according to the national market intended for the respective product. This may force a trade-mark proprietor to adapt different packaging standards according to the requirements in force in a particular Member State. Thus, in order to be able to resale in country $\mathrm{C} 2$ a product destined for country $\mathrm{C} 1$, a third party will be obliged to repackage that product, aiming to conform to the packaging regulations in force in $\mathrm{C} 2$.

It would constitute an artificial partitioning of markets if a trade mark owner were to rely on his trade mark rights to prevent changes in the packaging that are necessary in order to market the product in the Member State of importation. ${ }^{866}$

A court confronted with a dispute relating to repackaging of branded goods has to determine the question whether the marketing requirements in the Member States where importation is sought may be complied with without the need for repackaging. The court may particularly find out whether this end could be attained by "affixing to the original external or inner packaging new labels in the language of the Member State of importation, or by adding new user instructions or information in language of the Member State of importation, or by replacing an additional article not capable of gaining approval in Member State of importation with a similar article that has obtained such approval" ${ }^{867}$ Affirmative findings on this question will mean that the trade mark proprietor is entitled to oppose repackaging of his products in new external packaging.

$865 C f$. ECJ, joined cases C-427/93, C-429/93 and 436/93, Bristol-Myers Squibb v Panarova [1996] ECR I-3457, para. 53.

866 Cf. SCHUMACHER, C., "Use of trade marks on repackaged and relabeled pharmaceutical goods", in: PHILLIPS, J. (ed.), "Trade Marks at the Limit" 74 (Edward Elgar, Cheltenham 2006).

867 Cf. Bristol-Myers Squibb v Panarova [1996] ECR I-3457, para. 55. 
b) Condition of goods

A lawful repackaging by a third party does not have adverse effects to the condition of the goods inside the packaging. The trade mark proprietor is entitled to oppose repackaging if such repackaging is likely to affect the original condition of the product. There is no hard and fast rule to determine whether repackaging may affect the condition of the goods, as this question depends on the nature of the goods and the method of repackaging. ${ }^{868}$ In many cases, it can be presumed that the original condition of the product is not likely to be adversely affected if the products concerned have been marketed in a doublepackaging and that only the external (NOT the internal) packaging is affected by the repackaging. This presumption holds true also if the repackaging is subject to inspection by a public authority in charge of ensuring that there is no risk for the condition of the repackaged products to be adversely affected. ${ }^{869}$

Under certain circumstances, the original condition of the product inside the packaging may be affected indirectly and thus entitling the trade mark proprietor to oppose such packaging. Indirect adverse effect to the goods may be exemplified by two instances ${ }^{870}$ namely, where:

- the external or inner packaging of the repackaged product, or a new set of user instructions or information, omits certain important information or gives inaccurate information concerning the nature, composition, effect, use or storage of the product; or

- an extra article inserted into the packaging by the importer and designed for the ingestion and dosage of the product does not comply with the method of use and the doses envisaged by the manufacturer.

The indirect adverse effects to the condition of the goods cannot be confirmed, unless it is revealed, by a comparison between products marketed by the importer and those marketed by the trade mark proprietor that the information added by the importer contradicts the original information by the manufacturer.

\section{c) Notice of repackaging}

Repackaging will be opposed, unless the trade mark proprietor is given notice of that fact prior to the sale of the repackaged products. The parallel importer is

868 Hoffmann-La Roche \& Co. AG v Vertriebsgesellschaft Pharmazeutischer Erzeugnisse $m b H$ [1978] ECR 01139, para. 10.

869 Cf. Bristol-Myers Squibb v Panarova [1996] ECR I-3457, para. 60.

870 Cf. Bristol-Myers Squibb v Panarova [1996] ECR I-3457, para. 65. 
duty-bound "to furnish to the proprietor of the trade mark the information which is necessary and sufficient to enable the latter to determine whether the repackaging of the product under that trade mark is necessary in order to market it in the Member State of importation". ${ }^{871}$ In this connection, the trade mark proprietor may require the reseller to furnish him with some samples of the repackaged products in order to satisfy himself that the importer has repackaged the products in a way that does not affect the original condition of the goods. Indeed, this check mechanism will allow the trade mark proprietor an opportunity to discover some counterfeit goods, if any, among the repackaged goods. $^{872}$

Moreover, a trade mark proprietor's interest is to see that consumers understand that products bearing the proprietor's mark are marketed under his control and that the proprietor is responsible for their quality. It is thus natural for the trade mark proprietor to require a prior notice from marketers of repackaged products, on which the proprietor's mark is affixed. The notice gives the proprietor an opportunity to control by ensuring that consumers do not confuse the repackaged goods with the original goods. ${ }^{873}$

d) Identity of a person who repackaged the goods

The importer has to indicate clearly on the external packaging of the repackaged product that he, the importer, is responsible for the repackaging. ${ }^{874}$ Where the importer includes additional article in the repackaged product, he has to state that fact so that the consumer knows that the origin of the added article is not the trade mark proprietor but the third party who has repackaged the product. ${ }^{875}$ This information should be "in print such that a person with normal eye-sight, exercising a normal degree of attentiveness, would be in a position to understand". ${ }^{876}$

871 Cf. ECJ, Case C-276/05, The Wellcome Foundation Ltd v Paranova Pharmarzeutika Handels GmbH [2008] ECR I-10479, para. 2 of operative part of the judgment. The case is also reported in 40(7) IIC 874 et seq. (2009).

872 Cf. Bristol-Myers Squibb v Panarova [1996] ECR I-3457, para. 78.

873 Hoffmann-La Roche \& Co. AG [1978] ECR 01139, para. 12.

874 Cf. Bristol-Myers Squibb v Panarova [1996] ECR I-3457, para. 71.

875 Cf. Bristol-Myers Squibb v Panarova [1996] ECR I-3457, para. 73.

876 KITCHIN, D., et al, "Kerly's Law of Trade Marks and Trade names" (4th ed.) 553 (Sweet \& Maxwell, London 2005). 
e) Reputation of a trade mark

Reputation of a trade mark is a property nurtured by and protected for the benefit of the trade-mark proprietor. The proprietor has, by virtue of the specific subject matter of a trade mark, some legitimate interests to enjoin certain acts by third parties that would damage the reputation of trade mark. Inappropriate presentation of the repacked product may damage a trade mark's reputation notwithstanding a notice that might have been printed on the package indicating that the trade mark owner is not responsible for the packaging of the repackaged product. ${ }^{877}$ In examining whether a repackaged product presented in a particular manner is likely to damage reputation of the trade mark, preliminary regard must be directed to the nature of the products and the market for which the products are intended. The approach, based on the nature of the product, is necessary to distinguish between normal products such as those in the clothing industry and sensitive products such as those in the pharmaceutical industry in which only the high quality and integrity of the product concerned (including its packaging) may attract public confidence in relation to the product concerned. The market-based approach must be acknowledged for being decisive as to whether a trade mark's reputation is likely to be damaged through repackaging.

Insofar as sensitive products are concerned, it is always presumable that "defective, poor quality or untidy packaging could damage the trade mark's reputation". ${ }^{878}$ Indeed, if it is established that "repackaging of the pharmaceutical product is necessary for further marketing in the Member State of importation, the presentation of the packaging should be assessed only against the condition that it should not be such as to be liable to damage the reputation of the trade mark or that of its proprietor". ${ }^{879}$ Where pharmaceutical products, for instance, are destined to be sold to hospitals, packaging of the repackaged products may not damage reputation of the trade mark concerned as the representation of medicines is not relevant to professionals such as medical doctors who are responsible for administering medications to consumers. However, where the products concerned are sold to consumers through pharmacies, packaging of the product is of paramount importance, notwithstanding the duty of care inherent in

877 Cf. SCHUMACHER, C., "Use of trade marks on repackaged and relabeled pharmaceutical goods", in: PHILLIPS, J. (ed.), “Trade Marks at the Limit” 78 (Edward Elgar, Cheltenham 2006).

878 Cf. Bristol-Myers Squibb v Panarova [1996] ECR I-3457, para. 76.

879 Cf. ECJ, Case C-276/05, The Wellcome Foundation Ltdv Paranova Pharmarzeutika Handels GmbH [2008] ECR ECR I-10479, para. 1 of the operative part of the judgment. The case is also reported in 40(7) IIC 874 et seq. (2009). 
patient-doctor relationship that necessitates a conclusion that patients will build up confidence in medical prescriptions. ${ }^{880}$

2. Extension of repackaging principles to other case scenarios
a) Rebranding

A third party may be unable to import a product in a particular Member State if the trade mark affixed on the product contravenes the law of the country of import. This may necessitate rebranding the product, since it is only by substituting the proprietor's trade mark with another mark that meets the legal requirements a further commercialisation of the product will be possible in the country of import. ${ }^{881}$ However, rebranding cases do not fall within the precincts of Article 13(1) of CTMR. Where rebranding is in issue, the rights of the parties will be determined on the basis of Articles 34 and 36 of TFEU. Thus, the principles relating to the free movement of goods established in the context of repackaging and relabeling or re-affixing of a trade mark apply to rebranding cases as well. ${ }^{882}$

b) Removal of a stock code

In the light of the principles discussed above in the context of repackaging, it is interesting to inquire whether those principles could be relied upon by an importer who, in order to undertake a further commercialisation of the import products, is forced to remove the product identification code usually used by manufacturer to control distribution and redistribution of their products in the commercialisation chain.

880 Cf. Bristol-Myers Squibb v Panarova [1996] ECR I-3457, para. 77.

881 Cf. Davis, J., Intellectual Property Law, (2nd ed.) 305 (LexisNexis UK, London 2003). Cf. also J. Davis, Intellectual Property Law, (3rd ed.) 242 (Oxford Univ. Press, Oxford 2008).

882 EDENBOROUGH, M., "The Free Movement of Trade Marked Goods in the European Community", in: POULTER, A., BROWNLOW, P. \& GYNGELL, J. (eds.), "The Community Trade Mark: Regulations, Practice and Procedures" (2nd ed., Release \#4) XII.17 (INTA, New York 2005). 
The ECJ's judgment in Frits Loendersloot case ${ }^{883}$ whose contentious issue was whether relabeling of the products in order to remove the product identification code placed by the trade mark proprietor was illegal, provides some guidance as to when removal of product identification code can be allowed and vice versa. The decision to endorse the removal of identification code hinges on the effects that the respective codes would have on the internal market. This will always be determined in light of any existing product distribution scheme that the manufacturer might have devised. It is thus, upon the importer to show that, in view of that scheme, the identification codes help the trade mark proprietor to control and identify who sells which products to which importer. Importer's positive evidence will prove that the "identification numbers have been placed on products by producers to enable them to reconstruct the itinerary of their products, with the purpose of preventing their dealers from supplying persons carrying on parallel trade". ${ }^{884}$ In the circumstances, the importer's decision to remove the codes would be justified in view of the need to hide the identity of the distributor who supplied the products to him. In this connection, the court observed that:

...removal of the identification numbers might nevertheless prove necessary to prevent artificial partitioning of the markets between Member States caused by difficulties for persons involved in parallel trade in obtaining supplies from distributors for fear of sanctions being imposed by the producers in the event of sales to such persons. ${ }^{885}$

It is equally important to note that trade mark proprietors may, sometimes, decide to use product identification numbers with good intentions. For instance, a product coding system would be practically helpful in case the necessity to recall faulty goods arises. ${ }^{886}$ Sometimes the trade mark proprietor will use product code numbers in order to fulfil the requirements of the law. ${ }^{887}$ Moreover, the provisions of Article 13(1) CTMR entitle a trade mark proprietor to prohibit

883 ECJ, Case C-349/95, Frits Loendersloot v George Ballantine \& Son Ltd and others [1997] ECR I-06227.

884 Case C-349/95, Frits Loendersloot v George Ballantine \& Son Ltd and others [1997] ECR I-06227, para. 40.

885 Case C-349/95, Frits Loendersloot v George Ballantine \& Son Ltd and others [1997] ECR I-06227, para. 40.

886 EDENBOROUGH, M., "The Free Movement of Trade Marked Goods in the European Community", in: POULTER, A., BROWNLOW, P. \& GYNGELL, J. (eds.), "The Community Trade Mark: Regulations, Practice and Procedures" (2nd ed., Release \#4) XII.4 (INTA, New York 2005).

887 Cf. Council Directive 76/768/EEC of 27 July 1976 on the approximation of the laws of the Member States relating to Cosmetic products (OJ 1976 L 262, p. 169), which was implemented in the United Kingdom by the Cosmetic Products (Safety) Regulations 1996 (SI 2925/1996). 
marketing of the products in the EU where the proprietor sold the products in issue outside the EU single market. ${ }^{888}$ Thus, code numbers would for all practical matters enable the producer to identify importers who infringe the specific subject of his trade mark rights.

\section{c) Reworked products}

Article 13(2) of CTMR is relevant in many aspects. The clothing sector is not an exception to the rule stipulated in Article 13(2) of CTMR. The "Dyed Jeans" case $^{889}$ clearly reveals that the trade mark owner can legitimately prohibit the sale in the EU of jeans bearing its trade mark but which have been dyed by another party without the proprietor's consent, when they have been put on the market with the proprietor's consent in the EU. However, the court admits that not every incidence of dyeing will infringe the trade mark proprietor's legitimate interests and thus allowing him to interfere with further commercialisation of the goods - a right which would otherwise be considered exhausted but for the dyeing. The dyeing must be conducted in a way that changes the characteristics of the branded goods so that the trade mark owner is entitled to oppose further commercialisation of the goods. In this particular case, the court concluded that the defendant's act of dyeing the jeans in flashy colours interfered with the inherent quality of the jeans in question. The court had to analyse the defendant's motive behind the dyeing and found that the use of flashy colours instead of the original muted ones aimed to meet the interests especially demonstrated by young persons in flashily coloured jeans. In the court's view, the modification made to the jeans was tantamount to creating some new jeans. ${ }^{890}$

\section{Concluding summary}

The discussion in this chapter has revealed a healthy interplay between intellectual property rights and the single market's principle of free movement of goods achieved in the EU through some necessary concessions. The interplay

888 See the judgment of the Germany's Federal Supreme Court in "Dyed Jeans" 28(1) IIC 131 et seq. (1997), in which Article 13(1) of the CTMR applied and not Article 13(2), since the products whose original condition was claimed to have been changed were first sold in the US, and thereafter imported into the EU.

889 German Federal Supreme Court, "Dyed Jeans" 28(1) IIC 131, 133 (1997).

890 German Federal Supreme Court, "Dyed Jeans" 28(1) IIC 131, 133 (1997). 
ensures that intellectual property rights - trade marks in particular - are not based upon to distort competition in the EU's internal market. This has led to the acceptance of the basic principle that as long as the trade mark proprietor basis on the specific subject-matter of his trade mark rights to prohibit free movement of goods, such reliance is not a disguised restriction on trade between the Member States since, it is the only means for the trade mark concerned to perform its essential function.

The essential function of a trade mark does not entitle a trade mark proprietor to monopolise the after-market goods. Except where goods initially marketed by the trade mark proprietor are subjected to further processing or repackaging which affect or impair the condition of the goods, trade mark owners are not allowed to prohibit third parties from further commercialising the goods. It has thus emerged in this chapter that under certain circumstances, it will be necessary for the third parties to repackage the products, to re-affix the trade mark, and to rebrand the products, without a permission of the trade-mark proprietor. These activities are only allowed insofar as they are objectively necessary for the third party to access the market for the goods concerned. Where it is clear that the third party seeks to secure commercial advantages at the expense of the trade mark proprietor, the above-mentioned acts will be enjoined in the proprietor's commercial interests. 


\section{Chapter 7: A Model Trade Mark Regime for the East African Community}

\section{A. Introduction}

The task in this chapter is to depict a regional trade mark system that may contribute to the proper functioning of the EAC common market. To realise this goal, the ideal EAC trade mark regime should not only be capable of facilitating the free movement of goods and serve as a legal means of integrating branded goods into the system of intra-EAC competition, but should also be capable of affording manufacturers and marketers an opportunity to expand economic activities throughout the EAC without undue interference by third parties on the basis of trade mark rules of the individual Partner States. These objectives are articulated in EAC law ${ }^{891}$ and they reflect similar goals which actuated the EU to introduce the CTM system. ${ }^{892}$ This objective similarity provides a strategic ground for scrutinising the principles governing the EU's CTM system with a view to determining the extent to which the principles may be employed to establish the EAC trade mark system. In this regard, the chapter questions whether the key trade mark principles such as the unitary principle and the principle of trade mark coexistence underlying the EU's CTM system may be based upon to develop the envisaged EAC trade mark system. In a concrete approach, the chapter scrutinises the merits and demerits of these principles in relation to the regulation of regional trade mark rights. In a bid to redress the deficiencies (if any) inherent in the trade mark coexistence and unitary principles, the chapter resorts to the rules underlying the trade mark protection regime under the Benelux Uniform Trade Mark Law ${ }^{893}$ and the trade mark rules

891 In relation to the free movement objective $c f$. Articles 2(4) and 4(2) of the CMP, as well as the sixth recital to the CMP. With regard to the system of fair and free competition objective cf. Articles 33 and 36 of the CMP. In relation to general objectives of the EAC including extension of economic activities to the EAC scale $c f$. Article 5 of the EAC Treaty.

$892 C f$. Commission of the European Communities, "The need for a European trade mark system. Competence of the European Community to create one", Commission working paper No. III/D/1294/79-EN of October 1979, at p. 17.

893 The principles underlying the EU's CTM system "lean heavily for their derivation on the Benelux law of trade marks", hence the latter may be helpful in interpreting the former (cf. TATHAM, D. \& RICHARDS, W., "ECTA Guide to E.U. Trade Mark Registration" 22 (Sweet \& Maxwell, London 1998). 
that were devised to govern trade mark rights after the reunification of the Federal Republic of Germany. The hybrid of these principles ${ }^{894}$ will form a framework for the proposal regarding rules and principles that should govern the creation, maintenance and cession of EAC trade mark rights insofar as the contemplated EAC trade mark regime is concerned.

\section{B. Key Principles governing Community trade mark system}

CTMR enshrines the tenets of trade mark coexistence ${ }^{895}$ and the unitary character $^{896}$ as the centrepiece of the EU's CTM system. The question may be posed as to whether CTMR's principles mentioned in the immediately preceding sentence could be adapted for devising the EAC regional trade mark system. A negative response to this question would mean that the principles under discussion should necessarily be modified to make them suit the ideal EAC trade mark system. A deliberation on these issues follows below.

\section{The principle of unitary character}

The principle of unitary character is a legal technique that embellishes a particular regional trade mark system with more attractive features than those enjoyable under the national systems of trade mark protection. These features are reflected in the fact that when applied in relation to the Community trade mark system, the principle of unitary character, suggests avoidance of segmentation of the common market based on a system of protection of trade mark rights. ${ }^{897}$ The principle requires that Community trade marks be registered for, and the exclusive rights stemming thereof be protected to the scale of, the entire Community. ${ }^{898}$ In this sense, the Community trade mark registration must be

894 i.e. the principles underlying the EU's CTM system, the Benelux trade mark regime and Germany's trade mark system which was designed to concretise reunification of the East and West Germany after the cold war.

$895 C f$. section B (I) of chapter 5.

$896 C f$. Article 1(2) of the CTMR.

897 From a semantic point of view, the term "unitary" in the phrase "principle of unitary character" has been expounded as follows: "having the character of a single thing that is a constituent of a whole". <http://dictionary.reference.com/browse/unitary> (status: 30 July 2012).

$898 C f$. MÜHLENDAHL, A., "Koexistenz und Einheitlichkeit im Europäischen Markenrecht - Überlegungen zur Berücksichtigung älterer Rechte im künftigen europäischen Markenrecht für den Gemeinsamen Markt”, 25(1) GRUR Int. 27, 28 (1976). 
refused on the basis of prior rights existing in only one Partner State. ${ }^{899}$ The corollary of this is that a registered Community trade mark is vulnerable for revocation or cancellation even where the prior rights forming the basis for the invalidity proceedings are only protected in a single Member State of the regional organisation. Moreover, application of the principle of unitary character means that the Community trade mark rights can only be alienated or assigned for the whole territory of the regional organisation. ${ }^{900}$

\section{The principle of Coexistence of trade mark rights}

When applied in relation to national and regional trade mark protection regimes, the principle of coexistence ${ }^{901}$ connotes that introduction of a regional trade mark system does not become a replacement of, but a supplement to, the existing national trade mark protection schemes of the Member States of a given regional organization. $^{902}$ In this sense, the principle of trade mark coexistence allows existing national trade mark systems to operate alongside the regional trade mark scheme. ${ }^{903}$ Thus, the principle provides trade mark proprietors with a freedom to pursue their own business interests. A choice between the national and the regional trade mark systems should naturally be dictated by one's own business plans. In this regard, a trade mark proprietor wishing to trade to the scale of a regional bloc would find registration of his trade mark as a Community trade mark a suitable option, whereas a national trade mark registration would suit a person who has resolved to confine his business in a single Member State. Moreover, a person owning several registrations of the same mark in different Member States may decide to consolidate those national registrations into a Community trade mark registration while being assured by the principle of coexistence that should the consolidation process fail, or the consolidated

899 In relation to grounds for trade mark refusal, $c f$. section D of chapter 4 supra.

900 Under certain circumstances, exceptions that avoid the rigidity of the unitary principle are applicable. For instance, registration of a sign as a Community trade mark may be granted even where identical or confusingly similar prior rights of mere local significance are protected in one of the Member States (cf. by implication Article 8(4) of the CTMR).

901 The World English Dictionary defines the term "coexistence" to mean "to exist together at the same time or in the same place" (cf. $<\mathrm{http}$ ://dictionary.reference.com/browse/coexistence $>$ (status: 30 July 2012)).

$902 C f$. MÜHLENDAHL, A., "Koexistenz und Einheitlichkeit im Europäischen Markenrecht - Überlegungen zur Berücksichtigung älterer Rechte im künftigen europäischen Markenrecht für den Gemeinsamen Markt”, 25(1) GRUR Int. 27, 28 (1976).

$903 C f$. section B (I) of chapter 5. 
Community trade mark be cancelled, the national trade mark regime will avail him with protection of his trade mark based on the principle of trade mark conversion. ${ }^{904}$

It is noteworthy that the principle of trade mark coexistence has a direct connection with the principle of free movement of trade-marked goods underlying the EAC's common market. If, supposedly, the envisaged EAC regional trade mark system is designed to coexist with the national trade mark regimes, the chances that trade marks protected under the coexisting systems may conflict with one another are very high. This would in turn lead to several consequences such as restrictions on the free movement of goods, ${ }^{905}$ and distortion of competition in the EAC common market.

\section{Interaction between trade mark coexistence and unitary principles}

On the one hand, the principle of coexistence allows national trade mark systems to be maintained along with a regional trade mark regime irrespective of whether the national and regional trade mark rights may conflict with one another. But, on the other hand, the danger of trade mark conflict within the coexisting trade mark systems is minimised by the unitary principle, which allows registration of a trade mark only if there is no registration of similar mark in the national or in the Community trade mark register. ${ }^{906}$ Thus, the main role played by the unitary principle is to ensure that the coexisting trade mark regimes coexist in harmony without frictions resulting from conflicts between trade marks. Similarly, the principle applies only with respect to registrability of a Community trade mark, since failure of a trade sign to meet the requirement of the unitary principle and hence failure to meet registrability requirements does not mean that the trade sign cannot be registered as a national trade mark. In this sense, the solution to trade mark confusion provided by the principle of unitary character only addresses this problem ${ }^{907}$ in limited context of the relationship between national and regional trade mark systems. Thus, the principle does not solve the likelihood of confusion of national trade marks inter se. It instead exacerbates the danger of national trade mark confusion. In this regard, suppose that an

$904 C f$. MÜHLENDAHL, A., "Unitary Character and Problems of Coexistence in the future European Trade Mark System", 7(2) IIC 173, 177 (1976).

$905 C f$. BEIER, F.-K., "Industrial Property and the Free Movement of Goods in the Internal European Market" 21(2) IIC 131, 141 (1990).

906 But see the exception regarding prior rights of mere local significance implied in Article $8(4)$ of the CTMR.

907 i.e. Trade mark confusion. 
application for registration of a trade mark (say PUNCHO) as an EAC trade mark is refused on the ground that a PUNCHO national trade mark is already registered in Uganda. This refusal, which is basically actuated by the principle of unitary character, will mean that the applicant for an EAC trade mark will, pursuant to the principle of trade mark conversion, be allowed to register PUNCHO trade mark as a national trade mark in all EAC Partner States except in Uganda where a similar registration already exists. Application of the principle of unitary character as in the immediately preceding scenario will give rise to three legal problems. Firstly, the likelihood of trade mark confusion cannot be avoided since PUNCHO trade mark in Uganda is identical to PUNCHO trade marks in other EAC Partner States: It will be difficult for consumers to distinguish between, and clearly identify the origin of, the goods bearing the PUNCHO trade mark. In this sense, the trade mark will no longer serve its intended function. ${ }^{908}$ Secondly, the principle of free movement of goods underlying the EAC common market is likely to be circumvented: The proprietor of PUNCHO trade mark in Uganda will be able to prohibit PUNCHO goods from other EAC Partner States to circulate freely in Uganda. Thirdly, even if the principle of regional trade mark exhaustion ${ }^{909}$ is applied to the national trade mark as a legal guarantee that the PUNCHO proprietor in Uganda is restricted from invoking his trade mark to prohibit free circulation, in Uganda, of PUNCHO goods from other EAC Partner States, this will only solve the free movement problem but will not solve the danger of trade mark confusion.

These problematic aspects of the interface between the principle of trade mark coexistence and the unitary principle have to be addressed while devising an EAC trade mark system.

\section{Principles that should govern the EAC trade mark system}

Given the demerits inherent in the principles of unitary character and trade mark coexistence, it is sensible to question whether the proposed EAC regional trade mark system should be governed by these principles. It is particularly necessary to address the issue whether the legal problems associated with the application of the unitary principle ${ }^{910}$ may be solved by modifying the principle, for instance by relaxing the condition requiring the unitary character to be defined by the entire

$908 C f$. section C (I) (1) of chapter 3 in relation to a discourse on trade mark functions.

$909 C f$. section $\mathrm{C}$ of chapter 6 in relation to the principle of regional exhaustion of trade mark rights.

910 Explained in section B (III) supra. 
territory of the EAC common market; or whether the problems may be solved, once for all, if the unitary principle is abandoned. In relation to the principle of coexistence it might be questioned whether the abolition of the national trade mark systems; or whether employing the principle of coexistence as a transition to a single EAC regional trade mark regime could pave a way for acquisition of EAC trade mark to which the principle of unitary character applies. These issues are considered below.

\section{Modifications to the principle of unitary character}

The uniform Benelux law on marks ${ }^{911}$ may clearly explain the proposed modifications to the unitary principle governing the EU's CTM. ${ }^{912}$ In a proper analysis, one may discover that the law under discussion ${ }^{913}$ does not accentuate that a trade mark should have a unitary character in order to be registered and protected as a Benelux mark. Article 32 of the Benelux law enshrines a general rule that guarantees that the validity of a Benelux mark will be enjoyed to the territorial scale of the three Benelux countries. However, this rule is subject to two exceptions: The validity of a Benelux mark cannot extend to the territory of a Benelux country where another person lawfully owns an identical or similar Benelux trade mark effective in that territory; or where a trade mark which is a subject of extension would be regarded invalid either for lack of distinctiveness or due to other grounds for nullification of a trade mark. ${ }^{914}$ This implies that a

911 i.e. The Uniform Benelux Law on Marks (amended by the Protocol of November 10, 1983, amending the Uniform Benelux Law on Trademarks and by the Protocol of December 2, 1992, amending the Uniform Benelux Law on Marks) (henceforth, the Benelux law).The text is available at <http://www.wipo.int/wipolex/en/results treaty.jsp?col_id=\&organizations $=$ BOIP \& cat id $=4>$ (status: 30 July 2012).

912 The Uniform Benelux Law on Marks provides for a possibility of securing trade mark registration and protection effective in three countries forming up the Benelux territory, namely, the Kingdom of Belgium, the Kingdom of the Netherlands and the Grand Duchy of Luxembourg ( $c f$. Article 36 of the Benelux law). Prior to the establishment of the Benelux trade mark system, these countries had national trade mark protection regimes. The Benelux law incorporates some provisions which facilitated the transformation of national trade marks into the new regional trade mark regime ( $c f$. section C (II) (2) (b) of this chapter).

913 This law is not the current law (cf. last paragraph of section C (II) (2) (b) of this chapter). The law is therefore discussed here to indicate how the Uniform Benelux Law on Marks was initially designed and to see whether the same design may be adapted for designing the EAC trade mark system.

914 The grounds for nullity of a Benelux trade mark are outlined in Article 14 of the Benelux law. 
Benelux trade mark may be registered and have its effects in less than the three Benelux States. A trade mark lawfully registered in the Benelux becomes a Benelux mark regardless of whether it has effects in one, two or all three Benelux States. ${ }^{915}$

The proposal to either abandon the unitary principle or to relax the principle in such a way that trade mark's unitary characters are not necessarily required for the entire territory of the regional bloc clearly reflects the trade mark registrability requirements applicable in the Benelux. It only remains to assess the legal impacts such proposals might have on a regional trade mark regimes such as the envisaged EAC trade mark system.

\section{Abandonment of the unitary principle}

The central question under this heading is whether a regional trade mark system such as the proposed EAC trade mark regime could achieve its objectives if the trade mark rights protected under it are not subjected to the unitary principle. To address this issue, one should proceed from the premises that the abandonment of the unitary principle will justify the curtailment of the territorial scope of the EAC trade mark. Rights protected under the envisaged EAC trade mark system will no longer be unified and predictable: Non-observance of the unitary principle would mean that an EAC trade mark could even be granted to have its effect only in one EAC Partner States if similar or identical trade marks are already registered, as national trade marks, in other Partner States. In turn, this would lead to a situation whereby various identical or confusingly similar trade marks, both EAC and national trade marks, are registered and protected in the EAC common market. Under these circumstances, consumer confusion would not be avoided since similar or identical trade marks could be applied to identical or similar goods having different origins.

\section{Unitary character not to be defined by the entire scale of the regional bloc}

Alternatively, it may be debated whether granting registration of a trade mark as an EAC mark could make any sense if the unitary character of a registered trade mark is not rigidly required for the whole EAC territory. A positive response to this question would mean that an EAC trade mark could be registered to have its

$915 C f$. section C (II)(1) of this chapter, which shows that the only trade mark in existence in Benelux is a Benelux mark. 
effect in more than one Partner State but not necessarily in all EAC Partner States. In this sense, if a national trade mark identical to or confusingly similar with an EAC trade mark applied for is already registered and protected in Kenya, this should not be a reason to deny registration of the same trade mark as an EAC trade mark effective in Tanzania, Rwanda, Burundi and Uganda. Under the proposal at hand, it is possible to obtain unity of trade mark rights albeit to a lesser geographical area of the EAC.

\section{Justifications for the proposed modifications to the unitary principle}

As a condition for implementation in the EAC trade mark system, the proposed modifications to the unitary principle should contribute to the realisation of the key EAC interests. According to the stipulations under the EAC Treaty and the EAC Common Market Protocol, the EAC is interested to achieve the following goals: (a) the free movement of goods; (b) fair and free competition in trademarked goods; (c) providing manufacturers and marketers with legal means to extend economic activities to the EAC scale. ${ }^{916}$ These goals are discussed below.

\section{a) Free movement of goods}

The proposal requiring the unitary principle not to be necessarily defined by the entire territory of the EAC facilitates free movement of goods albeit in a limited manner: Pursuant to the proposal, goods bearing an EAC trade mark with effect say in four EAC Partner States may circulate freely to the scale of these four States. While this is not a complete answer to a situation whereby trade mark rights act as a barrier to the free movement of goods, it is an improved solution when compared with the proposal for the abandonment of the unitary principle. Both proposals ${ }^{917}$ do not remove the possibility that trade mark proprietors may invoke their exclusive trade mark rights to segment the EAC common market and thus restrict the free movement of goods. The only difference between the two proposals is the degree to which the segmentation is possible. By providing for the legal possibility of securing registration of an EAC trade mark in a single EAC Partner State, the proposal for the abandonment of the unitary principle facilitates dissection of the EAC common market in the same manner the

$916 C f$. Article 5 of the EACT and Articles 2(4), 4(2), 33 and 36 of the CMP.

917 i.e. the proposal requiring the unitary principle not to be defined by the entire EAC territory and the proposal for the abandonment of the unitary principle. 
proposal requiring the unitary principle not to be defined by entire EAC territory does. In line with the latter proposal, a trade mark proprietor may secure EAC trade mark registration covering two or more (but not all the five) EAC Partner States. This proposal may in effect serve as a conduit pipe for the segmentation of the EAC common market.

\section{b) Competition in trade-marked goods}

A trade mark is an instrument of competition. It extends to the proprietor a right to exclude others from the relevant market. ${ }^{918}$ The two proposals for the modification of the unitary principle described above make it hardly possible to integrate trade mark protection into a system of intra-EAC competition in trademarked goods. ${ }^{919}$ The proposals under discussion allow registration of a trade mark as an EAC trade mark notwithstanding the fact that the validity of the trade mark concerned does not extend to the scale of the entire EAC territory. Protection of an EAC trade mark as above cannot escape the consequence of the territoriality principle ${ }^{920}$ underlying national trade mark protection systems: An EAC trade mark registered to have its effects in one, two, three or four Partner States cannot be invoked to prohibit anti-competitive behaviour being perpetuated on the basis of a national trade mark protected in the fifth EAC Partner State where the EAC trade mark does not enjoy protection. This means that unless an EAC trade mark is registered to confer exclusive unitary rights to the EAC scale, competition issues relating to the exercise of the monopoly right of the EAC trade mark will be regulated based on the national competition regulatory framework. National trade mark law would strictly enforce the principle of territoriality pursuant to which a trade mark protected outside the national borders enjoys no protection within those borders. The result here is that goods bearing an EAC trade mark effective outside the borders of one EAC Partner State, cannot be placed within those borders to compete with identical or confusingly similar goods bearing a protected national trade mark which is identical with or confusingly similar to the EAC trade mark concerned. Under these circumstances, distortion of competition may not be regarded unfair since

918 Cf. Article 9 of the CTMR.

$919 C f$. Commission of the European Communities, "The need for a European trade mark system - Competence of the European Community to create one", Brussels, 1979 (III/D/1294/79-EN), p 17.

920 In relation to this principle $c f$. section B (II) of chapter 3. 
the EAC trade mark is not protected in the Partner State where the market entry is denied.

c) Unitary character as a means of expansion of economic activities

The abandonment of the unitary principle as a guiding principle of the proposed EAC trade mark regime means that a significant objective for which the EAC was established may not be realised. The EAC is charged with a duty to develop policies and programmes that are necessary for widening and deepening cooperation among the Partner States in various fields and affairs. ${ }^{921}$ This cooperation would inter alia lead to the attainment of "accelerated, harmonious and balanced development and sustained expansion of economic activities" in the EAC. ${ }^{922}$ In this regard, "trade marks enabling the products and services of undertakings to be distinguished by identical means throughout the entire $E A C$, regardless of frontiers, should feature amongst the legal instruments which undertakings have at their disposal". ${ }^{923}$ This calls for the introduction of the EAC trade mark system pursuant to which manufacturers and marketers should be able, by means of an uncomplicated, single procedure, to secure an EAC trade mark which is not only uniformly protected but also which is effective to the scale of the EAC.

While the measure to abandon the unitary principle is opposed to the objective of enabling manufacturers and marketers in the EAC to expand their economic activities, the principle of unitary character may still be instrumental for achieving the foregoing objective even where application of the principle is not necessarily defined by the entire territory of the EAC. Even where because a conflicting national trade mark is registered in one EAC Partner State the EAC trade mark cannot be registered to have effect to the EAC scale but only to the scale of four Partner States, still this allows the trade mark proprietor to market trade-marked goods throughout the territorial precincts of the four States by means of a single EAC trade mark and hence, extension of economic activity by means of an EAC trade mark.

$921 C f$. Article 5(1) of the EACT.

$922 C f$. Article 5(2) of the EACT.

$923 C f$. the third sentence, recital 2 of the CTMR. 


\section{Modifications to the principle of co-existence}

The legal problems associated with the application of the principle of unitary character are exacerbated by the principle of trade mark coexistence. The conditions to which the former principle is subjected do not give room for registration of a sign as a regional trade mark unless there is no identical or similar existing national trade mark or other prior rights protected at the national level. In order to ensure that the existence of national trade marks does not serve as a barrier against registration of several signs as EAC trade marks, the principle of trade mark coexistence should be modified. The possible modifications may include (a) abolishing the national trade mark registration and protection systems; (b) employing the principle of co-existence as an interim solution; and (c) employing the trade mark model under the German Extension Law, which concretised the re-unification of West and East Germany.

\section{Abolition of the national trade mark}

An alternative to a situation whereby national and Community trade marks coexist is to abolish the national trade mark protection systems. This should be done in a way that does not negatively affect the trade mark rights that are already secured. ${ }^{924}$ The Benelux trade mark system ${ }^{925}$ may be cited as an example whereby the national trade mark systems are abolished and the trade mark rights initially protected under the abolished national systems are transformed into regional trade marks. ${ }^{926}$

924 If abolition of national trade mark systems negatively affected the trade mark rights already protected under these systems, such abolition would be regarded to contravene property right which the constitutions of the EAC Partner States guarantee (cf. Article 24 of the Constitution of the United Republic of Tanzania, 1977 (as amended) (Cap. 2 of the laws of Tanzania), Article 75 of the Constitution of Kenya, Revised Edition 2008 (2001), and Article 26 of the Constitution of the Republic of Uganda, 1995 (as amended)).

925 Discussed in section C (II) (2) (b) below.

$926 C f$. TATHAM, D. \& RICHARDS, W., "ECTA Guide to E.U. Trade Mark Registration" 28 (Sweet \& Maxwell, London 1998). 


\section{Coexistence as a transition solution}

The fact that the national systems of trade mark protection already exist in the EAC Partner Sates means that coexistence of national trade marks and trade marks that will be protected under the proposed EAC trade mark regime cannot be avoided at least for a certain period of time. In other words, even where the national trade mark systems are abolished, the principle of trade mark coexistence may still be observed for some time as a means to facilitate smooth transition from national to regional system of trade mark protection. Coexistence modalities which are relevant in this respect are (a) the EU's CTM modality, which does not expressly incorporate a rule requiring all existing national trade marks to be transformed into Community trade marks, but embellishes the CTM regime with many advantages in a bid to allure trade mark proprietors to seek trade mark protection under the CTM system and hence the importance of national trade mark systems would gradually decline; and (b) the modality under the Benelux trade mark system pursuant to which trade mark coexistence is allowed for a certain period of time within which trade mark proprietors should actively transform their national trade mark rights into regional rights.

a) Incentives to ensure that the national system fades away

Under the "incentive" modality, it would not be necessary to take active legal action to abolish the national trade mark systems: The coexistence problem could be solved by employing legal techniques that make the EAC trade mark more attractive to the extent that proprietors could trust in the regime than they would in the national trade mark systems. The possibility of securing an EAC trade mark registration using one process and single application fee would be a sufficient economic ground to win over the interests of trade mark proprietors in the EAC trade mark system. A similar effect would be produced if protection of an EAC trade mark is subjected to single renewal process and fees.

These incentives have been tested under the EU's CTM regime, with a similar objective of making the regime more attractive in comparison with the national trade mark systems, ${ }^{927}$ but have hitherto not led to the diminishment of the national trade mark protection systems of the EU Member States. However, the failure of these incentives in the EU does not mean that their intended results cannot be realised in the EAC. It might turn out that the national trade mark 
systems in the EU still attract interests of trade mark proprietors on the basis of the quality of the services offered under the systems. Given that IP protection infrastructure in the EAC is generally weak in comparison with those in the EU, the trade mark incentives under discussion might produce positive results if employed under the EAC trade mark protection system.

However, even if the EU's national trade mark protection systems were weak, the incentives under discussion would not lead to the total disappearance of these systems so long as the system of trade mark conversion is still observed under CTMR: Trade mark conversion makes sense only if the national trade mark regime is there to accommodate the regional trade mark being converted into applications for national trade mark registrations. ${ }^{928}$ Therefore, if the incentives under discussion are to make any significant impact on the gradual disappearance of the systems of national trade mark protection of the EAC Partner States, the principle of trade mark conversion should not form part of the EAC trade mark jurisprudence.

b) The Benelux model: Transforming existing national trade marks into EAC trade marks

As a means to do away with coexistence of trade mark rights protected in two different systems of trade mark protection, a proposal requiring all existing national trade marks to be transformed into Community trade marks would hold water. The Uniform Benelux Law on Marks (henceforth, the Benelux law) employs a trade mark model which provides for the trade mark transformation from one system to the other.

In this regard, the Benelux law adopts the following approach: In the first place, coexistence of national rights and the regional trade mark rights secured under the Benelux law could coexist only for one year after the coming into force of the Benelux law. ${ }^{929}$ The coexistence was devised in order to allow proprietors of nationally protected trade mark rights an opportunity to upgrade their rights to regional level. ${ }^{930}$ If they did not do so within a year, the national trade mark rights would retrospectively cease to have effect from the day the

$928 C f$. Section B (III) of chapter 5, which discusses the principle of trade mark conversion.

$929 C f$. Article 30 of the Benelux Law.

930 According to Article 29 of the Benelux law, national trade mark rights include both registered and unregistered trade marks which were valid according to the national law before the coming into force of the Benelux law. Unregistered trade mark rights are secured by virtue of first use in trade of the mark. 
Benelux law came into force. The retrospective cessation of effect means that the national rights can no longer be invoked against registration of a Benelux mark even where the Benelux mark was applied for and registered within the one year period in which coexistence is allowed. This is due to the fact that any registered Benelux mark (be it a national trade mark transformed into a Benelux trade mark or a new trade mark applied for and registered as a Benelux mark) is deemed to have been valid as from the date of entry into force of the Benelux law. ${ }^{931}$

At this juncture, it is safe to endorse a position that the coexistence approach adopted under the Benelux law as a transition from national to regional based trade mark regime is a strategy that the EAC may adopt while transforming the existing national trade marks into the envisaged Community trade marks.

It is worth mentioning that the current Benelux trade mark regime differs from the one described above: The Benelux Convention on Intellectual Property (Trademarks and Designs) of 25/02/2005 (henceforth, the replacing law) has replaced the Uniform Benelux Law on Marks and its amending Protocols. ${ }^{932}$ The replacing law does not, for instance, refer to a situation in which a Benelux trade mark can be owned by two persons (who are not connected in trade) in different Benelux States. Thus, an inference can be drawn from the scope of trade mark protection stipulated under Article 2.20 of the replacing law that the new Benelux trade mark regime allows trade mark registration and protection for the entire territory of the Benelux States.

\section{The German trade mark model}

Two trade mark regulatory models are implicit in the trade mark regime that concretised the re-unification of West and East Germany in 1990. On the one hand, the regime avoids coexistence of trade mark systems by providing for cross-extension of the trade mark rights which were protected in the two parts of the Federal Republic of Germany. But, on the other hand, the regime permits coexistence of trade mark rights as opposed to coexistence of trade mark systems. Thus, the Unification Treaty concluded between the Federal Republic of Germany (FRG) and the Germany Democratic Republic (GDR) of August 31, $1990^{933}$ may offer a trade mark model that could possibly serve as a reference in

$931 C f$. Article 32 of the Benelux law.

$932 C f$. recital 1 of the Benelux Convention on Intellectual Property (Trademarks and Designs), (i.e. the replacing law).

933 The Treaty is available at http:/germanhistorydocs.ghidc.org/pdf/eng/Unification_Treaty.pdf (status: 30 July 2012). 
designing the EAC trade mark system. Article 3 of the Unification Treaty extended application of the basic law of the FRG to the GDR, since the GDR opted to join the FDR by accession. ${ }^{934}$ As a condition for the Unification Treaty to enter into force, the FRG and the GDR governments were required to fulfil certain internal requirements that were essential for the unification to materialise. ${ }^{935}$ In relation to industrial property rights for instance, the internal requirements were fulfilled by enacting the Law on the Extension of Industrial Property Rights of April 23, 1992. ${ }^{936}$

Pursuant to section 1 of the Extension Law, industrial property rights, such as trade marks, and the applications for such rights already existing on May 1, 1992, in the FRG were extended to the territory of the GDR and maintained their priority. Similarly, by virtue of section 4 of the Extension Law, industrial property rights, such as trade marks, and the applications for such rights already existing on May 1, 1992, in the GDR were extended to the territory of the FRG and maintained their priority.

While trade marks protected in the FRG and extended to the territory of GDR continued to be governed by the federal trade mark law, validity issues regarding trade mark rights created and protected in accordance with the trade mark law of the GDR and extended to FRG continued to be governed by this law. As concerns other trade mark issues, the GDR trade marks extended to the FRG are "governed by the provisions of the Federal law transferred to them under the Unification Treaty". 937

The cross-extension of trade marks and of applications for registration of trade marks stipulated in sections 1 and 4 of the Extension Law depicts an interesting legal scenario: An informed and inquisitive trade mark expert may wonder as to how, in such situation of cross-extension, the danger of trade mark confusion could be avoided. In this regard, the Extension Law offers a two-tier solution. In the first place, the Extension Law allows cancellation of a registered trade mark or opposition of registration of a trade mark if the challenging party satisfies the

934 Cf. Preuß, U.K., "German Unification: Expectations and Outcomes", Hertie School of Governance - Working Papers, No. 48, November 2009, at p. 4. The paper is available at<http://www.hertie-school.org/facultyandresearch/publications/workingpapers/working-papers/2009/> (status: 30 July 2012).

$935 C f$. Article 45 of the Unification Treaty.

936 i.e. Gesetz über die Erstreckung von gewerblichen Schutzrechten (ErstreckungsgesetzsErstrG) vom 23. April 1992 (i.e. The Law on the Extension of Industrial Property Rights (Extension Law-ErstrG) of April 23, 1992 (as last amended by the Law of August 30, 1994)). The law as last amended came into force on January 1, 1996. The text is available at $<$ http://www.wipo.int/wipolex/en/text.jsp?file_id=126205> (status: 30 July 2012).

$937 C f$. Section 5 of the Extension Law. 
relevant conditions. A third party seeking cancellation of a trademark extended to the GDR on the identity or similarity of marks ground must, in order to be successful, prove that the application leading to registration of a challenger's mark and which forms the ground for trade mark cancellation, was submitted to the FRG trade mark office not earlier than July 1, 1990 and not after October 2, $1990 .{ }^{938}$ A similar time condition applies to a person who seeks cancellation of a trade mark originally registered in the GDR and extended to the FRG by virtue of section 4 of the Extension Law, provided that the challenger's trade mark was extended to the GDR by virtue of section 1 of the Extension Law and such mark enjoys a priority date which is earlier than the trade mark being challenged. ${ }^{939}$ In relation to trade mark opposition, the Extension Law provides for the possibility of opposing an application for registration of trade mark which has been extended either to the GDR or FRG provided that before its extension the application was filed in the respective trade mark authority between July 1 and October 1990. In this regard, in case two applications for trade mark registration are pending before the trade mark authorities in both the GDR and the FRG, a trademark proprietor whose application for trade mark registration in the GDR is pending, may successfully base on his pending application to oppose extension to the GDR territory of the trade mark application filed in the FRG if the application pending in the GDR has a priority date which is earlier than that which the applicant in FRG enjoys. ${ }^{940}$ The opposite trail of this scenario means that if the trade mark application in FRG has an earlier priority date than that of the trade mark application in the GDR, the former trade mark application will form a basis for opposition of extension to the FRG territory of the latter trade mark application. ${ }^{941}$ This means therefore that, a proprietor of a trade mark (registered in the FRG) who has successfully extended his trade mark to the territory of GDR may successfully base on his trade mark rights to oppose extension to the FRG territory of similar or identical trade mark application provided that the trade mark serving a basis for opposition enjoys an earlier priority right than that of the trade mark application whose extension is being sought. ${ }^{942}$

Prospective trade mark rights pose no challenges insofar as trade mark conflicts are concerned, since the GDR trade mark regime became defunct in order to allow all future trade mark applications to be processed and protected to

938 Cf. Section 2 of the Extension Law.

$939 C f$. Section 21 of the Extension Law.

$940 C f$. Section 3 of the Extension Law.

$941 C f$. Section 23 of the Extension Law.

$942 C f$. Sections 3 and 23 of the Extension Law. 
the scale of the combined territory of the GDR and FRG based on a single trade mark law administered by the German Patent and Trade Mark Office. In relation to trade mark rights created before and after the dates mentioned above, ${ }^{943}$ the Extension Law also offers a model for solving trade mark conflicts. The general rule in this regard stipulates that trade mark conflicts resulting from crossextension of trade marks within the ambit of sections 1 and 4 of the Extension Law will be solved in the following manner: a GDR trade mark extended to the FRG territory will be used only in the GDR territory, and the proprietor of an FRG trade mark extended to the territory of the GDR cannot use his mark in the GDR. Under these circumstances, the trade mark may only be used in the prohibited territory, as per the foregoing elaboration, only if the proprietor of the competing trade mark consents to that use. ${ }^{944}$ Exceptions to this rule apply to allow a person who would otherwise be prohibited to market his trade-marked goods in one part of the Federal Republic of Germany (as per general rule) to use his mark in that part of the Republic without such consent of the owner of a conflicting trade mark. ${ }^{945}$

Irrespective of whether the exception to the general rule applies or not, the solution to cross-extension stipulated under the Extension Law allows coexistence of trade mark rights protected under a single law, owned by different persons, used for identical or similar goods. For that matter, the envisaged solution does not completely solve the problem of trade mark confusion: Pursuant to the general rule regarding the solution at hand, the use of trade marks is limited to the segmented territories of the GDR and the FRG. However, once the goods bearing the trade mark are sold in one part of Germany (be it the GDR or the FRG) are supposed to move freely to every part of the Federal Republic. ${ }^{946}$

943 i.e. the time between July 1 and October 1990 stipulated in sections 3, 21, and 23 of the Extension Law.

$944 C f$. Section 30(1) of the Extension Law.

945 Section 30(2) of the Extension Law outlines the conditions to be fulfilled in order for the exception to apply. The exception applies, in particular, if (1) the trade mark is used in the advertisement (say television or radio broadcasting, internet, and Newspaper advertisement), which from a technical point of view cannot be restricted to one part of the Federal Republic where the trade mark exclusively enjoyed protection before the extension, to the other part of the Republic, of the said mark (section 30(2), paragraph 1 ); or (2) "the owner can convincingly show that he is entitled, under the provisions of the Law on Property, to the return of the other mark or of the undertaking to which the other mark belongs" (Section 30(2), paragraph 2); or (3) "exclusion from use of the mark in that territory proves unreasonable taking into account all the circumstances of the case and weighing up the justified interests of those concerned and of the general public" (Section 30(2), paragraph 3).

946 This is because Germany is required, by virtue of Article 7 of the Community trade mark Directive, to implement in the Federal trade mark law the principle of regional trade 
This may lead to post-sale consumer confusion ${ }^{947}$ and thus allowing one of the two trade mark proprietors to trade on the coattails of the other's trade mark, depending on the degree of reputation and goodwill one trade mark enjoys in comparison to that enjoyed by the other mark. The danger of trade mark confusion is multiplied in the event the exception (under section 30(2) of the Extension Law) applies: Trade-marked goods of different origins will be marketed with the same or confusingly similar mark(s) in a single territorial market.

On the one hand, the risk of confusion inherent in the general rule regarding the solution to trade mark conflicts resulting from cross-extension does not allow a trade mark to serve as a legal means to extend economic activity to the scale of the whole territory of the Federal Republic of Germany. But, on the other hand, the exception to the general rule which is meant to allow proprietors to extend economic activity to the whole territory of the Federal Republic may lead to distortion of fair competition since trade mark proprietors are likely to trade on the coattails of another's trade mark.

While the trade mark model under the Extension Law may serve as a template for devising the EAC trade mark regime, the shortcomings contained in the Extension Law, particularly with respect to the danger of trade mark confusion, should be adjusted to suit the objectives for which the EAC trade mark system is to be established. ${ }^{948}$

\section{The Proposal for the EAC trade mark regime}

In the light of the discussion in the previous sections of this chapter, ${ }^{949}$ the trade mark regulatory models under the EU's CTM system, the uniform Benelux Law on Marks and the Germany's Extension Law have some strengths and weaknesses. The EAC trade mark protection system should be designed in such a way that it avoids the weaknesses of these models. In this regard, the EAC trade mark system should borrow the unitary principle underlying the EU's CTM system. In relation to the principle of trade mark coexistence, the EAC trade mark system should employ the principle of coexistence of EAC trade mark

mark exhaustion. This provision has been implemented by Article 24 of the Gesetz über den Schutz von Marken und sonstigen Kennzeichen (i.e. The German Law on the Protection of Trade Marks and other Signs (Trade Mark Law) of October 25, 1994 as amended).

947 Cf. INGERL, R. \& ROHNKE, C., "Markengesetz" (3rd ed.) 421( Beck, München 2010).

948 The objectives are described in section C (I) (3) of this chapter.

949 i.e. sections C (I) and (II) of this chapter. 
registers (i.e. trade mark register maintained by the national office and the register maintained by the EAC trade mark office). This is opposed to the principle of coexistence of national and Community trade mark regimes observed in the EU. The principles under the Germany's Law on Extension should be applied in the EAC context as a means to regulate national trade mark rights and applications for national trade mark registrations existing at the time when the EAC trade mark regime will have come into force, especially when it comes to transforming these rights into EAC regional trade mark rights.

\section{Acquisition of trade mark rights and the extent of validity}

The EAC trade mark system should be based upon both examination and nonexamination registration systems. Non-examination system of trade mark registration should be conducted at the national trade mark office; whereas the EAC trade mark office should be empowered to offer trade mark protection in respect of examined trade marks. A trade mark protected in the EAC should be unitary and its validity appreciated to the EAC scale.

\section{Non-examination system at national offices}

The role of national trade mark offices of the EAC Partner States should be changed from that of accepting and processing national trade mark applications to that of accepting and recording in the register existence of a trade mark owned by a proprietor who is a resident or established in the Partner State where recording is sought. The validity of a trade mark so recorded should extend to the entire territory of the EAC. However, a person whose trade mark has been recorded in the trade mark register of the Partner State must put that mark to genuine use in each of the EAC Partner States within the prescribed time as a condition for the prolongation of the exclusive rights. ${ }^{950}$

The national trade mark register of one EAC Partner State should be made electronically accessible to other EAC Partner States. ${ }^{951}$ In view of the envisaged accessibility, the national trade mark office should search in the national trade

950 Consequences of failure to comply with the use requirement are outlined in section D (I) (3) of this chapter.

951 In this regard, it is assumed that, in view of the current development level of internet technology and information society, it will be possible for one national office to access trade mark register of other EAC Partner States. 
mark registers to find out whether an identical or confusingly similar trade mark is already recorded in one of the national trade mark registers and which in effect would serve as a prior right against protection of trade mark whose recording is requested.

Under the recording system, there should be no trade mark opposition. The recourse to redress the grievances caused by recording of a trade mark should be pursued before the EAC trade mark office. This means that if objection is sought by a proprietor of another trade mark recorded in the national register, the proprietor must apply for registration of his trade mark with the EAC trade mark office as a condition for securing a standing to object recording of another conflicting mark in the national trade mark register. The same should apply when the objection is based on an unrecorded right. The same procedure should also be followed by a proprietor who wants to object registration of a trade mark at the EAC trade mark office. The fact that a proprietor of a trade mark recorded in the national register can challenge registration and/or the use of an identical or confusingly similar trade mark only if his trade mark is registered in the trade mark register maintained by the EAC trade mark office, or if application for registration in the EAC register has been filed, signifies the inferior legal protection enjoyed by an EAC trade mark recorded in the national register. In effect, the requirement will serve as an incentive to have many marks recorded in the national register being submitted to the EAC trade mark office for examination and registration in the EAC trade mark register, and hence stronger protection. On the other hand, the proposal for recording procedure takes into account the fact that trade mark examination requires a high level of technical and legal expertise which personnel in the national trade mark office may be lacking. Moreover, the recording system makes it easy for newcomers in the relevant market to access trade mark protection infrastructure than if the trade mark protection system in the EAC were centralised. Since under the recording system there should be no requirements for trade mark examination, trade mark protection costs would be much lower.

\section{Examination system at the EAC trade mark office}

Alternative to the recording system under the national trade mark regimes, the EAC trade mark office (manned with competent personnel) should be empowered to receive and examine trade mark applications and register the same as EAC trade marks. Registration of trade mark in the trade mark register maintained by the EAC trade mark office should be effected on the condition that proprietor of the mark has used or has signified his intention to use the trade 
mark concerned in each of the EAC Partner State within a time stipulated under the law. In order to be registered in the EAC trade mark register, there should not be in the national trade mark register an identical or confusingly similar trade mark with a priority date which is earlier than that of the trade mark whose registration is sought in the EAC register. In this regard, a trade mark recorded in the national trade mark register should serve as a ground for opposing registration of a trade mark in the EAC trade mark register. ${ }^{952}$

3. Trade mark use requirement and the consequences thereof

a) The use requirement

Any EAC trade mark should be subjected to the use requirement as a condition for the continuation of the validity of the trade mark concerned. This condition should apply for both trade marks recorded in the national register and those registered in the trade mark register maintained by the EAC trade mark office. In relation to this requirement, a trade mark should be used within a time limit specified under the law. This statutory time should be counted from the date of trade mark registration and from the day of any subsequent renewals of such registration.

b) Consequences of non-compliance with the use requirement

The consequences for non-compliance with the use requirement should differ depending on the register in which a trade mark concerned is registered.

Failure to put to genuine use ${ }^{953}$ (in each of the EAC Partner States) a trade mark registered in the EAC trade mark register should render that mark prone to deregistration. A proprietor of a trade mark deregistered as above should be allowed to file for recording of the same mark in the national trade mark register and maintain priority date of the deregistered mark, provided that the reason for deregistration was the proprietor's failure to use the trade mark to the scale of entire EAC territory. Therefore, recording in the national trade mark register of a deregistered mark should be allowed only if the trade mark has been used in at

952 See the requirements for objecting registration of a trade mark in the EAC trade mark register outlined in section D (I) (1) of this chapter.

953 Genuine use should be regarded to include use of a trade mark by licensees in relation to goods and/or services for which the mark is protected. 
least one Partner State. The use in one or more limited EAC States will indicate that the trade mark proprietor had either no commercial interests or sufficient financial capability to use the mark in other States, which altogether rule against conferring exclusive monopoly in the mark for the territories where the proprietor is unlikely to use the mark. Conditions regarding trade mark recording in the national trade mark register (except the time limit for complying with the use requirements) should apply to the deregistered trade mark under discussion. However, a deregistered EAC trade mark recorded into the national trade mark register should not enjoy the time limit for putting to genuine use of a trade mark originally recorded in the national trade mark register. This means that the consequences for non-compliance with the genuine use requirement regarding a trade mark recorded in the national trade mark register should apply forth-with to a trade mark deregistered from the EAC trade mark register.

Failure to put to genuine use a trade mark recorded in the national trade mark register should lead to two alternative consequences depending on whether the trade mark was not used in any Partner State at all; or whether it was used in one or few Partner States. In relation to a trade mark which was not used at all, third parties should be able to apply for registration of the same mark in the EAC trade mark register. Once the trade mark in issue is registered in the EAC register, recording of the same mark in the national trade mark register should immediately cease to have its effects. Regarding a trade mark recorded in the national trade mark register and which was put to genuine use in one or few Partner States, third parties in the Partner States where the mark was not put to genuine use should be allowed to register the same mark in the EAC trade mark register as an EAC collective mark. ${ }^{954}$ Coexistence of the registered EAC collective mark and the trade mark recorded in the national trade mark register which has failed to comply with the use requirement, which would result into trade mark confusion, should be avoided. To achieve this, the proprietor whose mark is recorded in the national trade mark register should be afforded an opportunity to adduce evidence regarding genuine use of his trade mark as a condition for registering the EAC collective trade mark by third parties. Even where he fails to prove the genuine use requirement to the entire EAC scale, the proprietor of the trade mark recorded in the national trade mark register must be one of the proprietors of the EAC collective mark so registered, provided that the proprietor of the recorded mark proves that his mark was at least used in one of the EAC Partner States. Loss of the right to use the mark will thereafter be undertaken in accordance with the rules governing proprietorship of the EAC collective marks.

954 It means that the EAC trade mark office will examine the trade mark concerned and register the same if it passes the registrability conditions. 


\section{Integration of the existing national trade mark rights into the EAC trade mark regime}

The term "national trade mark rights" is employed under this section to mean both trade marks registered and protected in the Partner States and applications for trade mark registrations pending in the national trade mark offices of the Partner States before coming into force of the proposed EAC trade mark protection regime.

\section{National trade mark registrations}

Trade marks protected in the EAC Partner States should be integrated into the EAC trade mark regime by extending the exclusive trade mark monopoly to the entire territorial scale of the EAC. In realising this, cross-extension of trade marks cannot be avoided: The validity of trade marks registered in Kenya will be extended to Tanzania, Uganda, Burundi and Rwanda; and vice versa. This crossextension would lead to conflicting trade marks being protected in the EAC common market - a situation which will lead to trade mark confusion and the consequences stemming thereof. ${ }^{955}$

To avoid the danger of trade mark confusion, the cross-extension of national trade marks should be formalised only after ex-officio examination of the national trade mark registers of all EAC Partner States has been undertaken to identify all conflicting trade marks. Proprietors of conflicting trade marks should be contacted by the trade mark conciliatory board (to be established) ${ }^{956}$ with the proposals as to how the conflicts may be resolved. It is only after resolving the trade mark conflict, the conflicting national trade marks may be entered into the EAC trade mark register.

\section{Applications for national trade marks}

Trade mark applications that will be pending before the national trade mark offices should, after the entry into force of the EAC trade mark protection

955 The consequences of trade mark confusion include the following: (a) restriction on the free movement of branded goods, (b) distortion of fair and free competition in trademarked goods, (c) a trade mark not serving as a legal means for extending economic activities to the EAC scale ( $c f$. section C (I) (3)of this chapter).

956 Duties of the conciliatory board are described in section D (II) (3) of this chapter. 
system, be treated as applications for EAC trade mark registrations. The EAC trade mark office should be empowered to examine these trade mark applications in light of the national trade mark law of the Partner State before whose trade mark office the application was initially filed. All trade mark applications of this category should be examined for compliance with the registration conditions. A trade mark which passes the substantive requirements test, and which do not conflict one another, should be registered in the EAC trade mark register. ${ }^{957}$ Those trade mark applications meeting the substantive requirements for trade mark registration but which conflict one another should be identified. Proprietors of the conflicting applications should be informed accordingly. Solutions to the conflicting applications should be processed through the trade mark conciliatory board.

\section{Conciliation board}

Conciliation as a means to resolve trade mark conflicts is not a new phenomenon. The success of the conciliation procedure in Germany, ${ }^{958}$ for instance, shows that the EAC trade mark regime also stands to benefit from the establishment of the conciliation board. The trade mark conciliation board should be established as a department in the EAC trade mark office. This department should be manned not only by legal (trade mark) experts, but also economists (who would determine the value of the conflicting trade marks, and the extent to which each proprietor has contributed to that value). The conciliation board should be empowered to aid the proprietors of conflicting trade marks to reach to an amicable settlement of the conflicts. The board's proposals in relation to trade mark conflict should be two-tier, namely, binding and non-binding proposals. In relation to a non-binding proposal, the conciliation board should, inter alia, suggest the following:

- To limit the goods and services in respect of which conflicting trade marks may be used so that while the trade marks remain identical, the list of goods and services is adjusted to avoid consumer confusion.

- The conflicting trade marks to be used in specific form, such as applying the marks on different packaging, provided that, in view of the

957 The conditions explained in section D (I) of this chapter should apply to the EAC trade mark under discussion as well.

$958 C f$. Part 3 of the Germany's Law on the Extension of Industrial Property Rights of April 23, 1992 cited above. 
board's finding, this measure is sufficient to allay the danger of consumer confusion.

- The proprietor who has not massively invested in the trade mark concerned to be fiscally compensated and leave registration of the trade mark in the EAC trade mark register in the name of the other proprietor who has invested in the mark.

In case there is no amicable agreement between the proprietors as per above proposals, the board should be empowered to issue some binding proposals for the avoidance of trade mark conflicts. In this regard, it would be practicable for the board to require the parties concerned to register the conflicting trade mark as an EAC collective trade mark. The board should be able to identify and propose the means to compensate the economic loss suffered by a proprietor, who has massively invested in the mark, as a result of consolidating the conflicting trade marks as above. In this sense, it should be the duty of the person who has not massively invested in the mark to compensate the other proprietor. If it appears that the proprietor who is required to compensate the other is financially incapable to do so, the board should have some funds from which compensation should be drawn. However, if the board compensates a trade mark proprietor as above, it should attain a status of co-owner of the trade mark concerned for the purposes of recovering the compensation paid. In this regard, the board should in effect be able to license the collective trade mark concerned. The owners of the collective trade mark so registered should have right to buy out the board's share in the mark. 


\section{Bibliography}

AIDE, C.M. \& DITTMER, S., "Registration and Enforcement of European Community Trade Marks: A Practical Guide", 14 I.P.J. 283 (1999-00).

ANNAND, R., \& NORMAN, H., "Blackstone's Guide to the Community Trade Mark" (Blackstone Press, London 1998).

BAINBRIDGE, D., "Intellectual Property" ( $7^{\text {th }}$ ed.), (Pearson Education Limited, Harlow 2009).

BASTIAN, E.-M., KNAAK, R. \& SCHRICKER, G. (eds.) "Gemeinschaftsmarke und Recht der EU-Mitgliedstaaten“" (Verlag C. H. Beck, München 2006).

BEIER, F.-K., "Der Schutz geographischer Herkunftsangaben in Deutschland” 65(4) GRUR $169(1963)$

BEIER, F.-K., "Industrial Property and the Free Movement of Goods in the Internal European Market” 21(2) IIC 131 (1990).

BEIER, F.-K., "Objectives and Guiding Principles of Future Trade Mark Law”, 8(1) IIC 1, 16 (1977).

BENDER, A. \& von KAPFF, P., "Born to be free - the Community Trade Mark in Practice", 32(6) IIC 625 (2001).

BENDER, A., "Die garfische Darstellbarkeit bei den neuen Markenformen", in: von BOMHARD, V. von, PAGENBERG, J. \& SCHENNEN, D (eds.), "Harmonisierung des Markenrechts: Festschrift für Alexander von Mühlendahl zum 65. Geburtstag am 20. Oktober 2005” (C. H. Verlag, München 2005).

BOMHARD, V. von \& PETERSENN, M., "Seniority under European Community Trademark Law", 92(6) Trademark Rep. 1327 (2002).

BOMHARD, V. von, "Dormant Trademarks in the European Union - Swords of Damocles?" 96(5) TMR 1122 (2006).

BOSSCHE, P. van den, "The Law and Policy of the World Trade Organization: Text, Cases and Materials" ( $2^{\text {nd }}$ ed.) (Cambridge University Press, Cambridge 2008).

BRONCKERS, M.C.E.J., "The Exhaustion of Patent Rights under WTO Law”, 32(5) JWT 137 (1998).

CARVALHO, N. P. de, "The TRIPS Regime of Trademarks and Designs" (Kluwer Law International, The Hague 2006).

CORNISH, W. R. \& LLEWELYN, D., "Intellectual Property: Patents, Copyrights, Trade Marks and Allied Rights" (6 $6^{\text {th }}$ ed.), (Sweet \& Maxwell, London 2007).

CORNISH, W.R. \& PHILLIPS, JENNIFER, "The Economic Function of Trade Marks: An analysis with Special Reference to Developing Countries", 13(1) IIC 41 (1982).

CORREA, C. M. \& YUSUF, A. A. (eds.), "Intellectual Property and International Trade: The TRIPS Agreement” (Kluwer Law International, Alphen aan den Rijn, 2008).

CORREA, C. M. "Trade Related Aspects of Intellectual Property Rights: A Commentary on the TRIPS Agreement” (Oxford University Press, Oxford 2007). 
COTTIER, T., “Trade and Intellectual Property Protection: Collected Essays”, (Cameron May Ltd, London 2005).

DAVIES, I. M., (ed.), "Sweet \& Maxwell's European Trade Mark Litigation Handbook" 36 (Sweet \& Maxwell, London 1998).

Davis, J., "Intellectual Property Law”, (2 $2^{\text {nd }}$ ed.) (LexisNexis UK, London 2003).

Davis, J., "Intellectual Property Law”, (3 ${ }^{\text {rd }}$ ed.) (Oxford University Press, Oxford 2008).

DAVIS, J., "To Protect or Serve? European Trade Mark Law and the Decline of the Public Interest”, 25(4) E.I.P.R. 180 (2003).

DHANJEE, R. \& CHAZOURNES, L. B. de, “Trade Related Aspects of Intellectual Property Rights (TRIPS): Objectives, Approaches and Basic Principles of the GATT and of Intellectual Property Conventions", 24(5) JWT 6 (1990).

DUMFARTH, P., "Prozessuale und materiellrechtliche Aspekte des Widerspruchsverfahrens der Gemeinschaftsmarkenverordnung" (Trauner, Linz 2008).

DURAN, L., \& ANNAND, R.E., "Seniority", in: POULTER, A., BROWNLOW, P. \& GYNGELL, J. (eds.), "the Community Trade Mark: Regulations, Practice and Procedure" ( $2^{\text {nd }}$ ed., Release \#4) (INTA, New York 2005).

EDENBOROUGH, M., "The Free Movement of Trade Marked Goods in the European Community", in: POULTER, A., BROWNLOW, P. \& GYNGELL, J. (eds.), "The Community Trade Mark: Regulations, Practice and Procedures" ( nd $^{\text {nd }}$ ed., Release \#4) (INTA, New York 2005).

EHRING, L., "De facto Discrimination in WTO law: National and Most-Favoured-Nation Treatment- or Equal Treatment?" Jean Monnet Working Paper 12/01 $<\mathrm{http} / / /$ centers.law.nyu.edu/jeanmonnet/papers/>

ENCHELMAIER, S., "the inexhaustible question - free movement of goods and intellectual property in the European Court of Justice's Case Law, 2002-2006”, 38(4) IIC 453 (2007).

EVANS, G.E., "The Comparative Advantages of Geographical Indications and Community Trade Marks for the Marketing of Agricultural Products in the European Union", 41(6) IIC 645 (2010).

FAMMLER, M. \& AIDE, C., "Enforcement of CTM in the EU: the real test of their commercial value", 86 J. Pat. \& Trademark Off. Soc'y 135 (2004).

FAWCETT, J. J. \& TORREMANS, P., "Intellectual Property and Private International Law" (Oxford University Press, Oxford 1998).

FERNANDEZ-NOVOA, C., "Die Verwirkung durch Duldung im System der Gemeinschaftsmarke", 45(4) GRUR Int. 442 (1996).

FEZER, K.-H., "Die Grafische Darstellbarkeite eines Markenformats", in: von BOMHARD, V., PAGENBERG, J., \& SCHENNEN, D. (eds.), "Harmonisierung des Markenrechts: Festschrift für Alexander von Mühlendahl zum 65. Geburtstag am 20. Oktober 2005" (C. H. Verlag, München 2005).

FEZER, K.-H., "Markenrecht” (13th ed.) (Verlag C.H. Beck, Munich 2009).

FIRTH, A. et al, "Trade Marks - Law and Practice" ( $2^{\text {nd }}$ ed.) (Jordan Publishing, Ltd., Bristol 2005).

FOLLIARD-MONGUIRAL, A. \& ROGERS, D., "the Community trade mark and designs system and the enlargement of the European Union", 26(2) E.I.P.R. 48 (2004).

FRANZOSI, M. (ed.) (1997), "European Community Trade Mark" (Kluwer Law International, Boston 1997). 
FRANZOSI, M., "Grey Market - Parallel Importation as a Trademark violation or an Act of Unfair Competition”, 21(2) IIC 194 (1990).

GASTINEL, E., \& MILFORD, M., "The Legal Aspects of the Community Trade Mark" (Kluwer Law International, The Hague 2001).

GEVERS, F., \& PIRE, J. L., "European Union, Enlargement to ten new Member States and the impact on the Community trade mark" in: POULTER, A., BROWNLOW, P. \& GYNGELL, J. (eds.), "the Community Trade Mark: Regulations, Practice and Procedure" ( $2^{\text {nd }}$ ed., Release \#4) XIII.7 (INTA, New York 2005).

GIOIA, F., "Alicante and the Harmonization of Intellectual Property Law in Europe" 41(1) CML Rev. 975 (2004).

GROSS, N., "Trade mark exhaustion: The U.K. perspective”, 23(5) E.I.P.R. 224 (2001).

HACKER, F., et al, "Das Verhältnis zwischen Marken und geographischen Herkunftsangaben (Q 191)", 55(8/9) GRUR Int. 697 (2006)

HAYS, T., "Distinguishing Use Versus Functional Use: Three Dimensional Marks", in: PHILLIPS, J. \& SIMON, I., (eds), “Trade Mark Use”, (Oxford University Press, New York 2005).

HEATH, C. "Parmigiano Reggiano by another Name: the ECJ's Parmesan Decision", 39(8) IIC 951 (2008).

HEATH, C., "The Most-Favoured Nation Treatment and Intellectual Property Rights", in: C. HEATH, C. \& SANDERS, K. (eds.), "Intellectual Property and Free Trade Agreements" (Hart Publishing, Oxford and Portland 2007).

HIDAKA, S., et al, "A sign of the times? A review of key trade mark decisions of the European Court of Justice and their impact upon national trade mark jurisprudence in the EU”, 94(5) Trademark Rep. 1105 (2004).

HORTWITZ, J. A., "Conflicting mark: embracing the consequences of the European Community and its unitary trademark regime" 18 Ariz. J. Int'l \& Comp. L. 245 (2001).

IHIJA, S. N., "Monitoring Mechanism for Elimination of Non-Tariff Barriers" - a project undertaken on behalf of the East African Community \& East African Business Council in 2009

$<$ http://www.eac.int/customs/index.php?option=com_content\&view=article\&id=4:ntbsmonitoring-mechanism\&catid $=3$ :key-documents\&Itemid $=141>$.

INGERL, R. \& ROHNKE, C., "Markengesetz" (3 ${ }^{\text {rd }}$ ed.) (Beck, München 2010).

INGERL, R., "Revised Regulation Governing Agents' Marks under the New German Trademark Act" 29(6) IIC 664 (1998).

ISAACS, N., "Law of Trade Marks" (CLT Professional Publishing, Birmingham 1996).

JACONIAH, J., "The Requirements for Registration and Protection of Non-Traditional Marks in the European Union and in Tanzania", 40(7) IIC 756 (2009).

JENKINS, N., "Litigation: Jurisdiction and procedure" in: POULTER, A.., BROWNLOW, P. \& GYNGELL, J. (eds.), "the Community Trade Mark: Regulations, Practice and Procedure" $\left(2^{\text {nd }}\right.$ ed., Release \#4) (INTA, New York 2005).

KIEFF, F. S., \& NACK, R., "international, United States and European Intellectual Property: Selected Source Material 2007-2008" (Aspen Publishers, New York 2006).

KITCHIN, D., et al, "Kerly's Law of Trade Marks and Trade names" $\left(4^{\text {th }}\right.$ ed.), (Sweet \& Maxwell, London 2005). 
KNAAK, R., "The legal enforcement of the Community trademark and prior national rights", 29(7) IIC 754 (1998).

KOOIJ, P.A.C.E. van der, "The Community Trade Mark Regulation: An Article by Article Guide" (Sweet \& Maxwell, London 2000).

KUR, A, "TRIPs and Trademark Law", in: BEIER, F., \& SCHRICKER, G. (eds.), "From GATT to TRIPs - The Agreement on Trade-Related Aspects of Intellectual Property Rights" IIC Studies Vol. 18 (VCH, Weinheim 1996).

KUR, A., "Strategic Branding: Does Trade Mark Law Provide for Sufficient Self Help and Self Healing Forces?" in: GOVAERE, I. \& ULLRICH, H. (eds.), "Intellectual Property, Market Power and the Public Interest" (P.I.E. Peter Lang, Brussels; New York 2008). $<$ http://ssrn.com/abstract $=1311243>$.

LANDES, W. M. \& POSNER, R. A., "Trademark Law: An Economic Perspective" 30 J.L. \& Econ. 265 (1987).

LUNDSTEDT, L., "Jurisdiction and the Principle of Territoriality in Intellectual Property Law: Has the pendulum swung too far in the other direction?" 32(2) IIC 124 (2001).

M.A. Consulting Group, "Study on the Establishment of an East African Community Common Market", (submitted to the EAC on 28th August 2007).

MANIATIS, S. M., "Whither European Trade Mark Law? Arsenal and Davidoff: The Creative Disorder Stage", 7 Marq. Intell. Prop. L. Rev. 99 (2003).

MANIATIS, S., "Trade Marks in Europe: A Practical Jurisprudence" $\left(1^{\text {st }}\right.$ ed.) (Sweet \& Maxwell, London 2006).

McGOVERN, P., "Conversion", in: POULTER, A., BROWNLOW, P. \& GYNGELL, J. (eds.), "The Community Trade Mark: Regulations, Practice and Procedure" $\left(2^{\text {nd }}\right.$ ed., Release \#4) (INTA, New York 2005).

McKeOUGH, J., STEWART, A. \& GRIFFITH, P., "Intellectual Property in Australia" (3 ${ }^{\text {rd }}$ ed.) 458 (LexisNexis Butterworths, Sidney 2004).

MÜHLENDAHL, A. von \& STAUDER, D., "Territorial Intellectual Property Rights in a Global Economy - Transit and other "Free Zones", in: PRINZ ZU WALDECK UND PYRMONT, W. et al. (eds.), "Patent and Technological Progress in a Globalized World, Liber Amicorum for Joseph Straus" (Springer, Berlin 2009).

MÜHLENDAHL, A. von, "Enforcement of Intellectual Property Rights - Is Injunctive Relief Mandatory?" 38(4) IIC 377 (2007).

MÜHLENDAHL, A. von, "Koexistenz und Einheitlichkeit im Europäischen Markenrecht Überlegungen zur Berücksichtigung älterer Rechte im künftigen europäischen Markenrecht für den Gemeinsamen Markt”, 25(1) GRUR Int. 27 (1976).

MÜHLENDAHL, A. von, "Seniority" (ECTA's special newsletter no. 30 of May 1996) (European Communities Trade Mark Association (ECTA) Secretariat, The Hague 1996).

MÜHLENDAHL, A. von, "Unitary Character and Problems of Coexistence in the future European Trade Mark System", 7(2) IIC 173 (1976).

MÜHLENDAHL, A. von, OHLGART, D. C. \& von BOMHARD, V., "Die Gemeinschaftsmarke" (Staempfli Verlag AG, Bern 1998).

National Economic Research Associates (NERA), SJ Berwin \& IFF Research, "Economic Consequences of the Choice of Regime of Exhaustion in the area of Trade Marks: Final Report for DG XV of the European Commission”, 1999. 
NIEDERMANN, A., "Surveys as evidence in proceedings before OHIM", 37(3) IIC 260 (2006).

PAGENBERG, J., “Opposition Proceedings for the Community Trademark - New Strategies in Trademark Law" 29(4) IIC 406 (1998).

PAGENBERG, J., "The Exhaustion Principle and "Silhouette" Case", 30(1) IIC 19 (1999).

PERTEGAS, M., "Intellectual property and choice of law rules", in: MALATESTA, A. (ed.), "The unification of choice of law rules on torts and other no-contractual obligations in Europe" (CEDAM, Padova/Milan 2006).

PETRIN, M., "Cancellation of Fraudulent Trademark registrations under the Lanham Act and the European Community Trade Mark Regulation" 11(2) Intell. Prop. L. Bull. 161 (20062007)

PHILIPS, J., "Trade Mark Law: a Practical Anatomy” (Oxford University Press, Oxford 2003).

PHILLIPS, J., "Trade Mark Law and the Need to Keep Free”, 36(4) IIC 389 (2005).

PHILLIPS, J., "Trade Mark Law: A Practical Guide” (OUP, New York 2003).

POUlTER, A., BROWNLOW, P. \& GYNGELl, J. (eds.), "the Community Trade Mark: Regulations, Practice and Procedure" ( $2^{\text {nd }}$ ed., Release \#4) (INTA, New York 2005).

PREUß, U. K., "German Unification: Expectations and Outcomes", Hertie School of Governance - Working Papers, No. 48, November 2009.

RADEN, L. van, "Community Trademark Courts - German Experience", 34(3) IIC 270 (2003).

RUSE-KHAN, H. G., “A Comparative Analysis of Policy Space in WTO Law”, Max Plank Institute for Intellectual Property, Competition \& Tax Law Research Paper Series No. 0802. $<$ http://ssrn.com/abstract=1309526>.

SANDRI, S., "Community Trade Marks and Domestic Laws", in: FRANZOSI, M. (ed.) (1997), "European Community Trade Mark" (Kluwer Law International, Boston 1997).

SCHUMACHER, C. "Use of trade marks on repackaged and relabelled pharmaceutical goods", in: PHILLIPS, J. (ed.), "Trade Marks at the Limit” (Edward Elgar, Cheltenham 2006).

SHYLLON, F., "Intellectual Property Law in Nigeria” IIC Studies Vol. 21 (Verlag C. H. Beck, München 2003).

SLOTBOOM, M. M., "The Exhaustion of Intellectual Property Rights - Different Approaches in EC and WTO Law", 6 JWIP 421 (2003).

SOUTH CENTRE, "The TRIPs Agreement - A Guide for the South: The Uruguay Round Agreement on Trade-Related Intellectual Property Rights" (South Centre, Geneva, 2000).

STAMATOUDI, I. A. \& TORREMANS, P.L.C., "International exhaustion in the European Union in the Light of "Zino Davidoff": Contract Versus Trade Mark Law", 31(2) IIC 123 (2000).

STUART, M., "The Function of Trade Marks and the Free Movement of Goods in the European Economic Community", 7(1) IIC 27, 34 (1976).

STUCKI, M., "Trademarks and Free Trade" 51 (Staempfli Verlag AG, Bern 1997).

SZYMANSKI, S., "International Exhaustion: A Review of Economic Issues" (Intellectual Property Institute, London 1999).

TATHAM, D., \& RICHARDS, W., "ECTA Guide to E.U. Trade Mark Registration” (Sweet \& Maxwell, London 1998). 
TORREMANS, P., "Holyoak and Torremans Intellectual Property Law" (5 $5^{\text {th }}$ ed.) (Oxford Univ. Press, Oxford 2008).

TREBILCOCK, M.J. \& HOWSE, R., "Regulation of International Trade" (Routledge, London and New York 2005).

TRITTON, G., "Parallel Imports in the European Community", A paper prepared for the Intellectual Property Institute - London, 1997.

VERMA, S.K., "Exhaustion of Intellectual Property Rights and Free Trade - Article 6 of the TRIPS Agreement" 29(5) IIC 534 (1998).

WEKESA, M. \& SIHANYA, B. (eds), "Intellectual Property Rights in Kenya" (Konrad Adenauer Stiftung, Berlin and Nairobi 2009).

WURTENBERGER, G., "Enforcement of Community Trade Mark Rights", 4 I.P.Q. 402 (2002).

YUSUF, A. A. \& von HASE, A. M., "Intellectual Property Protection and International Trade: Exhaustion of Rights Revisited", 16(1) World Competition 115.

ZARPELLON, S., "The scope of the exhaustion regime for trade marks rights", 22(9) E.C.L.R. $382(2001)$.

\section{Cited treaties, legislations and similar legal documents}

\section{International: WIPO/WTO}

Agreement Establishing the World Trade Organization (WTO) adopted at Marrakesh on 15 April 1994

Agreement on Trade-related Aspects of Intellectual Property Rights (TRIPS Agreement) (1994)

Madrid Agreement Concerning the International Registration of Marks of 14 April 1891, as revised and amended

Paris Convention for the Protection of Industrial Property of 20 March 1883, as revised and amended

Protocol relating to the Madrid Agreement Concerning the International Registration of Marks of 27 June 1989, as amended

The General Agreement on Tariffs and Trade (GATT) of 1994

The General Agreement on Tariffs and Trade (GATT) of 30 October 1947

WIPO's Standing Committee on the Law of Trademarks, Industrial Designs and Geographical Indications, "Relation of Established Trademark Principles to new types of Marks", Seventh Session (May 7 to 11, 2007) <www.wipo.int/edocs/mdocs/sct/en/sct_17/sct_17_3.pdf >

\section{EU/Member States/Benelux}

Benelux Convention on Intellectual property (Trademarks and Designs) of 25 February 2005 Commission of the European Communities, "Exhaustion of Trade Mark Rights" - A Working Document from the Commission Services of 21 June 1999. 
Commission of the European Communities, "possible abuses of trade mark rights within the EU in the context of Community exhaustion", Commission Staff Working Paper No. SEC (2003) 575.

Commission of the European Communities, "The need for a European trade mark system. Competence of the European Community to create one", Commission working paper No. III/D/1294/79-EN of October 1979.

Communication No $05 / 03$ of the President of the Office of 16 October 2003. $<$ http://oami.europa.eu/en/office/aspects/communications/05-03.htm $>$

Communication No 1/06 of the President of the Office of 2 February 2006 on extensions of the cooling-off period $<$ http://oami.europa.eu/en/office/aspects/pdf/col-06en.pdf>

Communication No $1 / 97$ of the President of the Office of 17 June 1997 concerning examination of seniority claims $<$ http://oami.europa.eu/en/office/aspects/communications/01-97.htm>

Communication No 2/00 of the President of the Office of 25 February 2000 concerning seniority examination, <http://oami.europa.eu/en/office/aspects/communications/0200.htm>

Communication No 2/00 of the President of the Office of 25 February 2000 $<$ http://oami.europa.eu/en/office/aspects/communications/02-00.htm>

Communication No 6/98 of the President of the Office of 14 November 1998 concerning examination of seniority claim $<$ http://oami.europa.eu/en/office/aspects/communications/06-98.htm>

Convention on Jurisdiction and Enforcement of Judgments in Civil and Commercial Matters of 27 September 1968 (Brussels Convention)

Council Directive 76/768/EEC of 27 July 1976 on the approximation of the laws of the Member States relating to Cosmetic products (OJ 1976 L 262, p. 169)

Council Regulation (EC) No 207/2009 of 26 February 2009 on the Community trade mark (codified version).

Council Regulation (EC) No 40/94 of 20 December 1993 on the Community trade marks (published in OJ L 11, 14.1.1994, p. 1)

Directive 2004/48/EC of the European Parliament and of the Council of 29 April 2004 on the enforcement of intellectual property rights, contained in OJ L 195, 2.6.2004, p. 16-25.

Directive No 2008/95/EC of the European Parliament and of the Council of 22 October 2008 (codified version), which repeals the First Council Directive No. 89/104/EEC of 21 December 1988 to approximate the Laws of the Member States Relating to Trademarks.

Gesetz über die Erstreckung von gewerblichen Schutzrechten (Erstreckungsgesetzs-ErstrG) (i.e. The German Law on the Extension of Industrial Property Rights (Extension LawErstrG) of April 23, 1992 (as amended)). OHIM Opposition Guidelines, 2004

OHIM Opposition Guidelines, 2007

OHIM's Statement No 5 of the Joint Statements [1996] O. J. O.H.I.M 613.

Regulation (EC) No 44/2001 of 22 December 2000 on Jurisdiction and the Recognition of Judgments in Civil and Commercial Matters (Brussels Regulation)

Regulation (EC) No 864/2007 of the European Parliament and of the Council of 11 July 2007 on the Law Applicable to Non-contractual Obligations (Rome II) 
The Gesetz über den Schutz von Marken und sonstigen Kennzeichen (i.e. The German Law on the Protection of Trade Marks and other Signs (Trade Mark Law) of October 25, 1994 (as amended)

Treaty on the Functioning of the European Union (Official Journal of the European Union No C $115 / 47$ of 9.5.2008)

Uniform Benelux Law on Marks (Consolidation) of 2 December 1992

United Kingdom Cosmetic Products (Safety) Regulations 1996 (SI 2925/1996)

United Kingdom Trade Mark Act of 1994

\section{Africa: ARIPO/EAC/EAC Partner States}

Banjul Protocol on Marks adopted by the Administrative Council at Banjul, The Gambia on November 19, 1993 (as amended)

Business Names Act Cap 213 of the laws of Tanzania

Companies Act No. 12 of 2002 (Tanzania)

Constitution of Kenya [R.E. 2009]

Constitution of the United Republic of Tanzania of 1977 (as amended)

Constitution of Uganda [R.E. 2000]

Lusaka Agreement on the creation of an Industrial Property Organization for English-Speaking Africa of December 1976 (as amended)

Patents Act No. 1 of 1987 (Tanzania)

Protocol on the Establishment of the East African Common Market of 20 November 2009

Protocol on the Establishment of the East African Customs Union of 2 March 2004

Trade and service marks Act (No. 12/86) of 1986 (Tanzania)

Trade Marks Act (Chapter 506 of the laws of Kenya) of 1957)

Trademarks Act (Chapter 217 of the laws of Uganda) of 1953

Treaty for the Establishment of the East African Community of 30 November 1999

Uganda Registration Services Bureau Act No. 7/1998 (Cap 210 of the laws of Uganda)

\section{Cited cases}

\section{EU/Benelux/Member States}

Adam Opel AG (Case C-48/05) [2007] ECR I-01017

Alfredo Nieto Nuño v Leonci Monlleó Franquet (Case C-328/06) [2007] ECR I-10093

Anheuser-Busch Inc v Budějovický Budvar (Case C-245/02), OJ C 6, 8.1.2005

Ansul (Case C-40/01) [2003] ECR I-02439

Arsenal Football Club plc v Matthew Reed (Case C-2006/01) [2002] ECR I-10273

Assembled Investments (Proprietary) Ltd v OHIM (Case T-105/05) [2007] ECR II-00060

Benetton Group SpA v G-Star International BV (Case C- 371/06) [2007] ECR I-07709

272 
BIC SA v OHIM (Case T-262/04) [2005] ECR II-5959

Björnekulla Fruchtindustrier (Case C-371/02) [2004] ECR I-05791

Blueco Limited's application [1999] E.T.M.R. 398

BMW v Ronald Karel Deenik (Case C-63/97) [1999] ECR I-00905

Brauerei Beck GmbH \& Co. v. Warsteiner Brauerei Haus GmbH \& Co. KG [1999] E.T.M.R. 225

Bristol-Myers Squibb v Panarova (joined cases C-427/93, C-429/93 and 436/93) [1996] ECR I3457.

British Sugar plc v. James Robertson \& Sons Ltd [1996] RPC 281

Campina Melkunie BV v Benelux-Merkenbureau (Case C-265/00) [2004] ECR I-01699

Canon Kabushiki Kaisha (Case C-39/97) [1998] ECR I-05507.

Canon Kabushiki Kaisha v Metro Goldwyn Mayer Inc (Case 39/94) [1999] ETMR 1

Celltech R\&D Ltd v. OHIM, 37(2) IIC 225, 226 (2006)

Centrafarm BV et Adriaan de Peijper v Winthrop BV (ECJ, Case C-16/74) [1974] ECR 01183

CINZANO (Case: I ZR 85/71), 4(3/4) IIC 432 (1973)

Citigroup, Inc. v OHIM (Case T-325/04) [2008] ECR II-00029

Claeryn/Klarein (Benelux Court) 7(3) IIC 420, 425 (176).

Colour of Elegance (I ZR 29/02), 37(2) IIC 226 (2006)

Concept - Anlagen u. Geräte nach 'GMP' für Produktion u. Labor GmbH v. OHIM (Case T$127 / 02$ ) (not reported in the ECR).

D.C.M.S., Inc. ('DATA CENTER WORLD') (OHIM, 29 April 2008, Case R 49/2008-4)

DaimlerChrysler AG v OHIM (Case T-355/00) [2002] ECR II-1939.

Dainichiseika Colour \& Chemicals Mfg. Co. Ltd. v OHIM (Case T-389/03) [2008] ECR II00058

Deutsche Grammophon Gesellschaft mbH v Metro-SB-Großmärkte GmbH \& Co. KG. (Case 78/70) [1971] ECR 00487.

Deutsche Renault AG v AUDI AG (Case C-317/91) [1993] ECR I-06227

Durferrit GmbH v. OHIM (Case T-224/01) [2003] ECR II-01589

Dyed Jeans" 28(1) IIC 131 et seq. (1997)

Dyson Ltd v Registrar of Trade Marks (Case C- 321/2003) [2007] ECR I-00687

El Corte Ingles SA v OHIM (Case T-443/05) [2007] ECR II-02579

Etablissements Consten S.a.R.L. and Grudig-Verkaufs-GmbH v Commission of the European Community (Joined cases 56 and 58-64) [1966] ECR 00299.

Eurocermex v OHIM (Case T-399/02) [2004] ECR II-1391

FON WIRELESS Limited (OHIM, 29 April 2008, Case R 1744/2007-5).

Ford Motor Company v. OHIM (Case T-91/99) [2000] E.C.R. 1925

Frits Loendersloot v George Ballantine \& Son Ltd and others (Case C-349/95) [1997] ECR I06227 
Gedo v Ente Nazionale Risi (Case C-2/73) [1973] ECR 865

General Motors Corporation v Yplon SA (Case C-375/97) [1999] ECR I-05421

Gerolsteiner Brunnen GmbH \& Co. V Putsch GmbH (Case C-100/02) [2004] ECR I-00691

Gillette Company and Gillette Group Finland Oy v LA-Laboratories Ltd Oy [2005] ECR I02337

HAG GF (HAG II) (Case C-10/89) [1990] ECR I-3711

Heidelberger Bauchemie GmbH (Case C-49/02) [2004] ECR I-6129

Henkel KGaA v. OHIM (joined cases C-456 P and C- 457/01 P) [2004] ECR I-05089

Hoffmann-La Roche \& Co. AG v Centrafarm (Case C-102/77) [1978] ECR 01139

Hoya Kabushiki Kaisha v OHIM (Case T-9/05) [2008] ECR II-00003

IHT Internationale Heiztechnik GmbH v Ideal-Standard GmbH (Case C-9/93) [1994] ECR, I02789

Intel Corporation Inc. v CPM United Kingdom Ltd (Case C-252/07) [2008] ECR I-08823.

Inter-Ikea Systems BV v OHIM (Case T-112/06) [2008] ECR II-00006

Koipe Corporación SL v OHIM (Case T-363/04) [2007] ECR II-03355

Koninklijke Philips Electronics NV v. Remington Consumer Products Ltd. (Case C-299/99) [2002] E.C.R. I-05475

Kristina KIK (Case C-361/01 P) [2003] ECR I-08283

La Mer Technology Inc. v. Laboratoires Goemar SA (Case C-259/02) [2004] E.C.R. I-1159

LEGO Juris A/S v MEGABRANDs Inc., (OHIM, Case R856/2004 G) [2007] ETMR 169

LEGO Juris A/S v. OHIM (Case T-270/06) [2008] ECR II-03117

Libertel Groep BV v. Benelux-Merkenbureau (Case C-104/01) [2003] ECR I-3793

Linde AG, Winward Industries Inc. \& RadoUhren AG (joined cases C-53/01 to C-55/01) [2003] ECR I-03161

Lloyd Schuhfabrik Meyer [1999] ECR I-3819

L'Oréal SA and Others v Bellure NV and Others (Case C-487/07) [2009] ECR I-05185

Mag Instrument, 29(3) IIC 316 (1998)

Mario Reichert v Dresdner Bank AG (Case C-261/90) [1992] ECR I-02149

Matthias Rath v Portela \& Ca., S.A. (OHIM, 30 April 2008, Case R 1630/2006-2)

Maja case, 66(7) GRUR 372(1974).

Medion AG (Case C-120/04) [2005] ECR I-08551

Merz \& Krell GmbH \& Co., v. Deutsches Patent- und Markenamt (Case C-517/99) [2001] E.C.R. I-6959.

Michael Hölterhoff v Ulrich Freisleben [2002] ECR I-04187

Mülhens GmbH \& Co. KG v OHIM (Case T-150/04) [2007] ECR II-02353

274 
Myles Ltd's Application, (OHIM, Case R 711/1999-3) [2003] ETMR 718

Nichols plc v Registrar of Trade Marks (Case C-404/02) [2004] ECR I-08499

Nokia Corp. v Joacim Wärdell (Case C-316/05) [2006] ECR I-12083

OHIM v Shaker di L. Laudato \& C. Sas (Case C-334/05 P) [2007] I-04529

Parke, Davis and Co. v Probel, Reese, Beintema-Interpharm and Centrafarm (Case 24/67) [1968] ECR 00055

Peak Holding AB v Axolin-Elinor AB (Case C-16/03) [2004] ECR I-11313

Pharmacia \& Upjohn SA v Paranova A/S (Case C-379/97) [1999] ECR I-0692

Philips v Remington (Case C-299/99) [2001] ETMR 509

Philips v Remington [1998] ETMR 124

Quelle AGv OHIM (Case T-88/05) [2007] ECR II-00008

Ralph Sieckmann (Case C-273/00) [2002] ECR I-11737

Real Time Consultants v Manpower (Da Vinci device) (Case R-906/2001-1), O.J. OHIM 7$8 / 02$

Redcats SA v OHIM (Case T-246/06) [2008] ECR II-00071

Sabel BV v. Puma AG (Case C- 251/95) [1997] ECR I-06191

SAT.1 Satellitenfernsehen GmbH v. OHIM [2005] 1 C.M.L.R. 57

Sebago Inc. SA v G-B Unic SA (Case C-173/98) [1999] ECR I-04103, para. 16.

Shield Mark BV v. Joost Kist h.o.d.n (Case C-283/01) [2003] ECR I-14313

Silberquelle GmbH v Maselli-Strickmode GmbH (Case C-495/07)[2009] ECR I-00137

Silhouette International Schmied GmbH \& Co. KG v Hartlauer Handelsgesellschaft mbH (ECJ, Case C-355/96) [1998] ECR I-04799

Sirena S.r.l. v Eda S.r.l. and others (Case 40/70) [1971] ECR 00069

Telefon \& Buch VerlagsgmbH v. OHIM [2001] 3 C.M.L.R. 3

The Procter \& Gamble Company v OHIM (Case T-122/99) [2000] ECR II - 265; [2000] E.T.M.R. 580

The Wellcome Foundation Ltd v Paranova Pharmarzeutika Handels GmbH (Case C-276/05) [2008] ECR I-10479; 40(7) IIC 874 et seq. (2009).

Three Stripes trade mark [2002] ETMR 553.

Toshiba Europe GmbH v. Katun Germany GmbH (Case C-1112/99) [2001] ECR I-7945

Unilever NV v OHIM (Case C-194/01) (not reported in the ECR)

Usinor SA v OHIM (Case T-189/05) [2008] ECR II-00022 
Van Doren + Q. GmbH v Lifestyle sports + sportswear Handelsgesellschaft mbH and Michael Orth (Case C-244/00) [2003] ECR I-03051

van Uden Maritime (Case C-391/95) [1998] ECR I-07091

Vennootschap onder Firma Senta Aromatic Marketing's Application, (OHIM, Case R 156/1998-2) [1999] ETMR 429

Verein Radetykz-Orden v Bundesvereingigung Kameradschaft 'Feldmarschall Radetzky' (Case C-442/07) [2008] ECR I-09223

Wagamama Ltd v City Centre Restaurants plc [1996] ETMR 307 (HC)

Windsurfing Chiemsee Produktions- und Vertriebs GmbH v. Boots- und Segelzubehor Walter Huber and Attenberger (Joined cases C-108/97 and C-109/97) [1999] E.C.R. I-2799

Xentral LLC v OHIM (Case T- 134/06) [2007] ECR II-05213

ZinoDavidoff SA (joined cases C-414/99 to C-416/99) [2001] ECR I-08691

\section{EAC/Partner States}

Aktiebolaget Jonkoping-Vulcan v East African Match Co. Ltd, (HCU) [1964] 2 ALR Comm. 176

Kibo Match Group Ltd v. Mohamed Enterprises (T) Ltd., Civil Case No. 6 of 1999 (HCT, CCD, Dar Es Salaam Registry (unreported)).

Match Masters Ltd v Rhino Matches Ltd, Civil Suit 314 of 2006 (HCK (CCK) registry) [2006] eKLR

Pharmaceutical Manufacturing Co v Novelty Manufacturing Ltd, Case Number: 746/98 (CCK) [2001] 2 EA 521

Samaki Industries (Nairobi) Ltd v Samaki Ltd (K) Ltd (2), Case Number: 235/96 (CAK) [199598] 2 EA 366

SUPA BRITE Ltd v PAKAD Enterprises [1970] 2 EA563

Tanzania Breweries Ltd v Kibo Breweries and Kenya Breweries, Civil Case No. 34 of 1999 (HCT, Dar Es Salaam Registry (unreported))

\section{GATT/WTO}

Appellate Body Report, Korea - Measures Affecting Imports of Fresh, Chilled and Frozen Beef, T/DS161/AB/R, WT/DS169/AB/R, adopted 10 January 2001, DSR 2001:I, 5 